\title{
DE TO LOINANG VAN DEN OOSTARM VAN CELEBES,
}

(met 6 foto's, 2 kaarten en 4 tekstfiguren)

DOOR

\author{
Dr. ALB. C. KRUYT, \\ Zendelingleeraar van het Nederlandsche Zendelinggenootschap.
}

\section{In leiding.}

In de maanden Juni en Juli van het jaar 1928 heb ik vier weken onder de To Loinang doorgebracht. Dit is een volkje, dat op den Oostelijken arm van Celebes woont, in hoofdzaak aan den loop van de Loboe-rivier; later heeft het zich ook verspreid naar het bovenland van de Boenta-rivier. Deze twee rivieren ontlasten hun water in de Tominibocht. In lateren tijd moet een klein deel van deze menschen zich gevestigd hebben aan den Zuidkant van de waterscheiding. Velen van deze laatsten zijn thans gevestigd in dorpen aan den grooten weg van Batoei naar Loewoek. De voornaamste vestiging aldaar is Doombola.

Toen het Gouvernement in deze streek kwam, hebben de To Loinang zich zonder tegenstand aan het nieuwe gezag onderworpen. Alleen is het optreden van een patrouille soldaten in 1907 oorzaak geweest, dat zich een paar Hoofden van de Baloa-clan hebben verzet, en daarom moesten worden neergelegd. Dit optreden heeft de lieden die hooger in de bergen wonen, schuw gemaakt, zoodat het tot nu toe moeite kost met hen in aanraking te komen. Tot voor korten tijd namen ze nog de vlucht bij de nadering van Europeanen, en verbergden zich in de wildernis.

In tegenstelling met de bergbewoners zijn de Loinangs die meer raar de kust toe wonen voor het grootste deel tot het Christendom overgegaan. Dit heeft uiterlijk een groote verandering teweeggebracht: de menschen gaan over het geheel goed gekleed, en velen hunner spreken Maleisch. In de dorpen langs de Loboe zijn te Pinapoean, Lingketeng, Tamboenan en Baloa onderwijzers gevestigd, die behalve school houden ook het Evangelie verkondigen. In het benedenland van de Loboe is een school gevestigd te Balean. Onder D1. 86. 
de Loinangs in het achterland van de Boenta zijn scholen opgericht te Tombonga en te Koninis; de laatste echter is kortelings opgeheven uit gebrek aan leerlingen.

Over den naam Loinang heb ik geen inlichting kunnen krijgen. Zooals het meer met zulke namen gaat, noemen de menschen zich zelven niet zoo. „Wij weten dat de vreemdelingen ons To Loinang noemen,” zegt men, „maar wij kennen het woord niet.” Een deel van het volk noemt zich ,menschen van Kintom”, omdat zij den Sengadji van Kintom als heer erkenden; en een ander deel noemt zich „menschen van Tangkian”, naar de woonplaats van hun eigen Sengadji. Beide deze plaatsen zijn gelegen aan de zuidkust van den Oostarm, aan de Golf van Tolo.

Meer is bekend de naam Saloean. Een deel van den kop van dit schiereiland is bewoond door het Saloean-volk. Deze naam wordt vooral gebruikt om de gemeenschappelijke taal dezer menschen aan te duiden, de basa Saloean, die over de Oostelijke helft van dit schiereiland verspreid is, en alleen in enkele dialekten onderscheiden wordt, zooals het Saloeansch, het Balantaksch en het Loinangsch.

Kort na mijne vestiging te Poso in 1892 hoorde ik den naam Loinang noemen. $\mathrm{Nu}$ en dan werd door de bewoners van Poso een tocht naar het gebied der Loinangs ondernomen om er koppen te snellen. In het binnenland van de Loinangstreek zijn de Posoërs echter nimmer geweest; ik heb hiervan althans geen overlevering bij deze menschen kunnen vinden.

De eerste man van wetenschap, die deze streek bezocht heeft, was Dr. J. Wanner, die in 1905 den Oostarm bereisde. Een beschrijving van zijn tochten heeft hij gegeven in Petermanns Mitteilungen, Februari en Maart-aflevering 1914, onder den titel van „Eine Reise durch Ost Celebes". De geologische resultaten van deze reis waren toen reeds gepubliceerd in Neues Jahrbuch für Mineralogie, Band 29, 1910.

Dr. Wanner maakte een tocht in het bovenland van Kintom, waarbij hij een aantal nederzettingen van Loinangs vond. Nog drie andere tochten werden in het kustgebied ondernomen, waarna de reiziger via Biak en Poh naar de Tominibocht overstak om ook het gebied ten Noorden van het scheidingsgebergte te onderzoeken. Van Pangimanan uit reisde Wanner naar Dolong aan de Loboe, welke rivier verder naar de monding toe werd gevolgd tot Balean. Toen ging het via Dolong over het gebergte naar Salean. Van daar over Mongolos naar Pinapoean. Verder over de Sensean naar de 
dorpenreeks van Lingketeng, en eindelijk weer terug over de Sensean naar Soloedoek.

Had de reiziger tot nu toe weinig te klagen gehad over de bevolking, in het dorpencomplex van Lingketeng werd dit anders. In Pinapoean had men hem al tegen willen houden, en te Indang werd hem den toegang tot het dorp door een troep bewapende mannen belet. Te Bahingin vond hij toen een onderkomen in de woning van het Hoofd, Daka'njo. Van hier ging het naar Soloedoek aan den voet van het hooggebergte, en van daar trok hij in drie dagen over de waterscheiding naar Kintom.

Aan de hand van wat Wanner vertelt, geef ik hier in 't kort een beschrijving van het pad, dat in den ouden tijd meermalen door de lieden van Lingketeng werd begaan, wanneer zij hun heer of hunne verwanten te Kintom bezochten. Tegenwoordig wordt het zelden meer gevolgd, tenzij dan door een patrouille soldaten.

Dadelijk buiten Soloedoek, een dorp dat niet meer bestaat, gaat het pad steil bergopwaarts, zoodat men op een afstand van $2 \frac{1}{2}$ à 3 K.M. 550 M. steigt. Maar dan is men ook op een breed plateau, dat zich 10 K.M. ver naar het Zuiden uitstrekt. Aan het eind er van gekomen, is men $100 \mathrm{M}$. hooger gestegen en dicht genaderd tot het punt vanwaar het gebergte naar de Molukkenzee afvalt.

Den eersten nacht wordt gewoonlijk in een spelonk doorgebracht, Liang Boto genaamd, die zich vele kilometers ver in het kalkgebergte zou uitstrekken tot in de nabijheid van Pinapoean. Den volgenden dag is men al spoedig op de zuidelijke helling van het gebergte, dat niet zoo steil afloopt als aan den Noordkant. Als men in het dorp Toipang is aangekomen, is men weer in het gecultiveerde gebied. Van hier loopt het pad langs het riviertje Tondoeno in zuidelijke richting, en als men de Mendono is overgestoken, is men in een paar uur te Kintom.

Ofschoon de ontmoetingen, die Dr. Wanner met de bevolking heeft gehad, teekenend beschreven zijn, vertelt deze geleerde niet veel van de bewoners der bereisde streken.

In het einde van 1919 brachten Dr. W. Kaudern en zijn gezin twee en een halve week onder de Loinangs door. Hij had zijn verblijf in Pinapoean genomen, en van hier uit maakte hij een uitstap naar het Lingketang-complex en naar Tamboenan. Een verder doordringen naar Baloa moest in verband met de omstandigheden achterwege blijven. Kaudern had zeer te klagen over de ongastvrijheid en onvriendelijkheid van de menschen, zoodat ze hem niet eens hun 
gebruiksvoorwerpen lieten zien, laat staan aan hem verkoopen. Een van deze ontoeschietelijke menschen was het Hoofd, de tonggol ${ }^{1}$ ) van Pinapoean, Talahata genaamd, van wien deze reiziger nog een goed gelijkend portret heeft geschilderd. Deze man is sedert dat bezoek wel veranderd, want hij heeft mij zes dagen lang met het grootste geduid van 's morgens vroeg tot het vallen van den avond op al mijn vragen geantwoord, zoodat ik een vrij volledig beeld van dit volk kreeg, dat ik op andere plaatsen kon controleeren en aanvullen.

De menschen van Lingketeng en Tamboenan waren vriendelijker tegenover Dr. Kaudern, zoodat deze daar nog een verzameling ethnografica bijeen heeft kunnen brengen. Niettegenstaande de geringe medewerking heeft deze geleerde toch nog vele bizonderheden van dit volk bijeen kunnen brengen, al waren ze niet voldoende om een aaneengesloten beeld van dit volk te vormen. Voor zijn reis naar en verblijf onder de To Loinang zie men zijn werk I Celebes obygder, 1921, tweede deel, hoofdstuk 12 en 13, bl. 284-340.

Voorts heeft de Heer E. Gobée in den tijd dat hij Assistent resident van Poso was (1924-1926) eenige malen de To Loinang bezocht, en zijn aandacht voornamelijk op hun taal gevestigd, waarvan mettertijd wel een en ander zal worden gepubliceerd. Ik mocht van zijne aanteekeningen gebruik maken, waardoor het mij makkelijker is gevallen om mij met de Loinangs te onderhouden.

In het begin van 1926 bracht de gewestelijke arts van Manado Dr. W. E. L. Weck een kort bezoek aan de lieden in het Simpangsche, van welke gelegenheid hij gebruik heeft gemaakt om eenige anthropologische onderzoekingen onder dit volk te verrichten, waarvan de resultaten voor zoover mij bekend nog niet gepubliceerd zijn.

Gedurende mijn verblijf onder de Loinangs heb ik mij voor langeren tijd opgehouden te Pinapoean, Bahingin, Tamboenan, Koninis en Bangkoehan; deze laatste plaats als uitgangspunt voor de Mantam-streek. Van mijne zegslieden noem ik hier de voornaamsten : Talahata Lambajang, Hoofd van Pinapoean, ${ }^{2}$ ) Jacob Koetondong (als Heiden heette hij Lalekang), vroeger dorpshoofd, thans ouderling van de Christelijke gemeente te Tamboenan; Koehanga Mondjawap,

1) Aan het strand zegt men tonggol, in het binnenland daarentegen spreekt men van tonggon. Er zijit vele voorbeelden van hetzelfde verschijnsel. Aangezien tonggol door alle buitenstaanders gebruikt wordt, volg ik dit voorbeeld na. Op het woord zelf kom ik nog terug.

2) Men zie de reproductie van zijn fraai en goedgelijkend portret in Kaudern's I Celebes obygder, II, bl. 328. 
onderdistriktshoofd (kapitan) van Lingketeng, en het onderdistriktshoofd van Mantan (woonplaats Koninis), wiens naam mij ontschoten is. Verder hebben de drie inheemsche onderwijzers, en verscheiden andere menschen mij inlichtingen gegeven.

\section{Beschrijving van het Land.}

Wanneer men het woongebied van de Loinangs bereizen wil, moet men als uitgangspunt nemen de kustplaats Pangimanan. Drie K.M. ten Oosten van deze plaats woont in het oord Lembangan het distriktshoofd van Mendono, zooals de streek tegenwoordig heet (oorspronkelijk is Mendono een plaats aan de zuidkust, aan de Molukkenzee). Pangimanan is een vrij aanzienlijke handelsplaats, uitsluitend bewoond door vreemdelingen; iedere vier weken doet een boot van de Kon. Paketvaartmaatschappij de plaats aan. Van hier gaat een aangelegde weg naar het binnenland. Tot nu toe is die ,weg" niet meer dan een paardenpad, dat alleen in den drogen tijd te berijden is, omdat er groote stukken in voorkomen, waar men in den regentijd tot aan de knieën door de modder gaat. Het tracé is echter heel goed, en als er aan gewerkt wordt, zal dit pad met weinig moeite in een goeden weg zijn te veranderen.

In den omtrek van Pangimanan, op weinige kilometers van daar, liggen eenige kleine vestigingen van Loinangs, die voor het meerendeel tot het Christendom zijn overgegaan. Aanvankelijk voert het pad in zuidwestelijke richting tot de rivier Pooehoea is bereikt, een van de vele rivieren met kort verloop, die zich door het gebergte een weg banen naar de Tominibocht. Dicht bij de monding er van wonen ook Loinangs, die zich daar in lateren tijd hebben gevestigd. Is men de Pooehoea over, dan gaat de weg meer zuidelijk. Van de berghelling die men langs trekt, heeft men nu en dan een heerlijk gezicht op een deel van de Togian-eilanden. Het eiland Walea vertoont zich in al zijn lengte aan het oog.

Van dit gebergte spoeden zich verscheidene rivieren en beken naar het diepe ravijn, dat men rechts van zich heeft, en waardoor de Loboe haar water naar zee stuwt. Zoo heeft men er de Hako, die in de Bololang valt, en dan in de Loboe uitmondt. Verder de Kolobias en de Bonto. De grootste van de beken die men op dit deel van het terrein overtrekt, is de Loema'an. Men is hiermee weer in bewoond gebied gekomen. $\mathrm{Na}$ een kleinen klim vanaf de rivier bereikt men het dorp Salingan (,voorbeeld, monster”). Een tweede klim brengt ons op 
een kleine bergvlakte, die in het midden ingezakt is. Aan deze omstandigheid dankt het gehucht, dat daar staat, den naam van Mongolos, dat zulk een plek aanduidt. Dit gehucht ressorteert onder het dorpshoofd van Salingan.

Van hier is het nog slechts een paar kilometer naar het groote dorp Pinapoean. De afstand van Pangimanan naar Pinapoean bedraagt 26 K.M. Pinapoean is afgeleid van papoe (pa-apoe) en beteekent ,waar verbrand is", nl. het dorp. De voormalige vestiging lag meer naar het Noorden, en deze werd door de strandbewoners om de eene of andere reden verbrand, toen de inwoners er van zich op de akkers bevonden. Pinapoean is nu de naam van een complex van kleine kampongs vlak bij elkaar: Lombe, Sopa (,,pisangspruit”), Pangi (een boom met eetbare bladeren, Pangium edule), Salean (,de plaats waar men het salefeest vierde). Andere gehuchten zijn verlaten, en de inwoners er van wonen nu in Pinapoean, of zijn naar de kuststreek verhuisd, zooals Damak (,damarhars”), en Boehangas (de naam van een soort leem, tano boehangas, die bij regen anstonds tot modder wordt). Andere dorpen die onder het Hoofd van Pinapoean staan zijn Panimboelan (,,bergrug”) en Padang (,grasvlakte”). Dit laatste ligt reeds aan de overzijde van de Sensean; de inwoners van die plaats hebben verzocht naar Pinapoean te mogen verhuizen, maar het onderdistriktshoofd staat dit niet toe.

Over al deze kampongs is één Hoofd aangesteld, die in elk der gehuchten een onderhoofd heeft. In den ouden tijd werd met Pinapoean deze geheele streek aangeduid, en het Hoofd er van voerde (len titel van Tonggol (in het binnenland tonggon). Deze titel komt veel voor op Celebes als tongko. Onder de Poso-Toradja's werd er een Hoofd mee aangeduid, die door den radja van Loewoe of van Mori was aangesteld om een heele streek te vertegenwoordigen (tongko beteekent in 't Boegineesch ,dekken, bedekken”, iemand dus die een landstreek bedekt, daarvoor instaat: tenzij het hier een op zichzelf staande beteekenis heeft). Bij de Sa'dan-Toradja's komt het nog voor in het woord tongkon-an, ,stamhuis", plaats van den tongkon of tonggol. Dat de macht van den tonggol van Pinapoean zeer is ingekrompen, hindert hem nog steeds. Op het tonggol-schap kom ik beneden nog terug.

Van uit Pinapoean heeft men naar het Zuidwesten het gezicht op een bergrug, waarop met kleine onderlinge afstanden vier dorpen liggen; van Zuid naar Noord: Lingketeng (de naam van een klimplant), Indang (de naam van een boom), Bahingin (,waringin”) en 
Hejoeha (de naam van een kruid). De gemiddelde hoogte van dezen rug is 600 meter. Om er te komen daalt men van Pinapoean in het dal van de Sensean, een zijrivier van de Loboe, af. Aan de overzijde gekomen moet men voortdurend klimmen; eerst komt men door het reeds genoemde dorpje Padang, hoogerop door Boelakan (een uit den grond opwellende bron); de plek waar vroeger Boemboele (de naam van een knolgewas) lag, laat men rechts liggen, en dan lereikt men na een laatsten steilen klim de Lingketeng-kam tusschen de dorpen Indang en Lingketeng. Indang ligt op het hoogste punt er van (een goede voorstelling krijgt men van het pad, dat naar Indang leidt, door fig. 119, bl. 293 van Kaudern's I Celebes obygder, II). De afstand van Pinapoean tot op den Lingketeng-kam bedraagt slechts 41/2 K.M., maar het klimmen eischt veel inspanning.

Van hier uit heeft men overal een zeer fraai gezicht op het ravijn waardoor de Loboe stroomt, en op het gebergte aan de overzijde daarvan. Iets daarvan laat ons fig. 123, bl. 297 van I Celebes zien; deze opname is genomen van uit het dorp Kolomboi. Naar zee toe ziet men het eiland Walea voor zich uitgestrekt. Verder naar het Westen wordt het uitzicht op de zee afgesneden door de uitloopers van het gebergte, die naar het ravijn van de Loboe afdalen. In Bahingin woont het onderdistriktshoofd of kapitan van de door Loinangs bewoonde streek aan de Boven-Loboe.

Het pad dat ons verder van Lingketeng langs het Loboe-ravijn voert, levert weinig bezwaren op, daar het in de berghelling is uitgegraven. Al spoedig na Lingketeng komt men in het reeds genoemde Kolomboi. Er bestaat onder deze menschen blijkbaar een zucht om de namen hunner dorpen te verklaren ; zoo vertelde men van Kolomboi, dat dit zou afgeleid zijn van lombo, dat beteekent: een kleedingstuk of iets dergelijks over een horizontaal geplaatsten stok hangen; dit zou men gedaan hebben, toen men dit dorp aanlegde. Hier wonen de menschen die eertijds het 3 K.M. verder gelegen Banta hebben bewoond; deze lieden zouden een afzonderlijke clan hebben uitgemaakt, waarover straks meer. Op dezen weg trekt men een aantal beken over, waarvan de Solo poendo de grootste is; vóór deze is men de Beleo overgegaan, en daarna krijgt men de Lawana. Een korte maar stevige klim brengt naar het gehucht Doehian (,Doerian”), dat van Tamboenan uit gesticht is. Een beeld van dit uit twee huizen bestaande gehucht geeft fig. 124, bl. 298 van I Celebes, II.

Van hier heeft men het ravijn van de Aloe waja door te trekken om in Tamboenan (,hoop, stapel”) te komen. Van Lingketeng tot 
Doehian bedraagt de afstand 9 K.M. Tamboenan ligt 11/2 K.M. verder. Tamboenan is een groot dorp met een eigen Hoofd (de fig. 125 en 126 van I Celebes, II geven een indruk van dit dorp). Van hier uit heeft men een mooi uitzicht op de omringende bergen, de Lokait (een rotansoort), de Pojoe en de Kawean beto'eon (,waar men naar (le maan reikt”), met de daarachter liggende Damak (,damarhars”). Een lagere berg, de Angkap, ligt meer naar het Noorden; een uitlooper van het gebergte, dat zich aan den rechteroever van de Loboe verheft, en dat den naam van Angetan draagt, belet het oog om van Tamboenan uit den heuvelrug van Lingketeng waar te nemen.

De hoogste berg naar het Zuiden is de Boeloe Toempoe ,berg van den eigenaar”, of ,berg die de eigenaar, d.i. de voornaamste is”. Op dezen bergknoop zouden volgens de Inlanders de Batoei, de Tobolombang, de Boenta, de Toimaa, en de Loboe ontstaan. Een kleinere berg, de Posini, ligt er voor, evenals de Homboeha en de Boengka maninis.

Dr. J. Wanner geeft in zijn „Eine Reise durch Ost Celebes” een overzicht van dit gebergte, zooals het zich aan zijn oog voordeed van uit Salean (Pinapoean): „Die exponierte Lage dieses Ortes (Salean) auf einer schmalen Bergrippen etwa $650 \mathrm{M}$. Höhe gewährt eine vortreffliche Uebersicht über das Gebirge an beide Seiten und an den Quellen der Lobu. Nach S. zu erblickt man den steilen Nordwestabfall des Zentralgebirges, das die Eingeborenen Hoho nennen, d. h. „,der grosse Wald”. Sein Kamm zieht sich nach S.W. zu fast eben und ohne Unterbrechung bis zum Hompu hin und senkt zich dann langsam nach dem Tale der Lobu zu herunter. Davor schiebt sich wie eine Kulisse eine Bergrippe ein, die vom Hompu abzweigt und auf ihrem ebenen Kamm die Dörfer Lingketeng, Indang, Bahingin, Momolos und Kabu trägt und dan schroff zur Lobu abfällt. Aus dem Tale dieses Flusses selbst steigt in der Richtung S. $52^{\circ} \mathrm{W}$. am rechten Ufer ein. isolierter, steiler, oben gerundeter Kegel auf, der Angatan, eine wegen ihrer eigenartigen Form auffallende und in dem Landschaftsbild dieses Gebirges fremdartige Erscheinung .... Auf der linken Talseite der Lobu sieht man anschliessend an den Bulutumpu ungefähr hinter der Angatan fünf Bergrippen kulissenartig in das Tal vorspringen, von denen die nördlichste, der Kawean-Bituon, mit seinem nach S. steil abfallenden Gipfel die übrigen weit überragt. Nach den N. senkt sich dieser Kamm ganz allmählich ab und taucht hinter dem breiten Rücken des Tendatenda unter. ${ }^{1}$ )

1) De in dit stuk genoemde Hompoe zal de Homboeha zijn; de naam Hompoe is onbekend. In de rij van dorpen op den Lingketeng-rug is Mongolos (niet 
Het laatste dorp van deze streek is Baloa (,waar balo-bamboe-is”), dat ruim vier K.M. verwijderd ligt van Tamboenan, en dat van hier uit duidelijk te zien. Om er te komen moet men het ravijn van de Loemoek (,mos”), een van de bronrivieren van de Loboe overtrekken. Vóór de komst van het Gouvernement was Baloa een groot dorp met veel inwoners, maar later zijn velen naar het bovenland van Boenta verhuisd.

Van Baloa kan men over de bergen reizen naar het tweede woongebied der Loinangs in het pas genoemde binnenland van Boenta. Men moet daartoe een nacht in de wildernis doorbrengen. Ik maakte dezen tocht niet, maar keerde terug naar Pinapoean om van daar via Dolong naar Loboe te reizen. Daartoe volgt men eerst het pad dat naar Pangimanan leidt om, als men dit 5 K.M. lang gedaan heeft, links af te slaan en het gebergte af te dalen. Dit gaat vrij steil. Het is een uitlooper van het gebergte, die men daarbij volgt, en die later tot een steilen klim dwingt. De afstand van Salingan naar Dolong zal niet meer dan 13 K.M. bedragen, maar door het moeielijke terrein doet men er lang over. Dolong en de verder naar het strand toe gelegen dorpen zijn voornamelijk van uit Pinapoean en Lingketeng bevolkt.

Van Dolong gaat de weg langs de Loboe-rivier, waarbij men deze elf maal heeft over te trekken. Waar de vallei van deze rivier breeder wordt, vindt men aan haar linkeroever een aantal nederzettingen van Loinangs, namelijk Kadodi, Balean (waar een school is), Bomban en Nioeboelan. Daar tijdens mijn bezoek aan deze streek de rivier banjirde, moest ik een pad aan den rechteroever volgen om aan het strand te komen. Dit pad gaat over zwaar terrein, waarbij men verscheidene uitloopers van het gebergte dwars over te klimmen heeft. Op 1 K.M. afstands van Dolong steekt men de Bololang over, een rechterzijrivier van de Loboe, die ontstaat uit de Bololang, de Hako en de Bombin. De afstand tot het dorp Loboe an het strand zal misschien 10 à 11 K.M. zijn.

Loboe is een handelsplaats vanwaar veel copra wordt uitgevoerd. De oorspronkelijke bewoners van dit dorp waren Loinangs van Lingketeng, die naar het strand zijn afgedaald en die later door invloed van vreemdelingen Mohammedaan zijn geworden. Nadat het Gouvernement hier gekomen is, hebben vele Gorontaleezen zich in Pangi-

Momolos) geen dorp maar cen kleine inzinking in den bergkam, waar tegenwoordig de pasanggrahan staat. Kaboe bestaat niet meer; de inwoners zijn naar het Dolongsche verhuisd. 
manan, Loboe en Boenta gevestigd, die daar als koelies in de kokostuinen werken.

Langs het strand van de Tominibocht is een weg aangelegd. Van Poh tot Pangimanan is de afstand 28 K.M., van daar tot Loboe 20, en van hier weer tot Boenta $30 \mathrm{~K}$.M. Met een prauw liet ik mij van Loboe naar Boenta brengen.

In Boenta heeft het landschap een geheel ander voorkomen dan in de reeds genoemde kustplaatsen. Een uitgestrekte vlakte heeft zich hier vóór het gebergte uitgespreid, die door verscheidene rivieren wordt doorsneden. De voornaamste daarvan is de Boenta. In het gelijknamige dorp aan de monding van deze rivier woont het Distriktshoofd, Sengadji, van het distrikt Tangkian, onder wien de Loinangs van deze streek staan.

Na 10 K.M. van Boenta geloopen te hebben langs de rivier, komt men aan het dorp Hion ,de gedoornde”, zoo genoemd beweert men naar de sagobosschen die men hier vindt, omdat deze palm gedoornd is. Hier wonen Loinangs die voor een deel Mohammedaan zijn en voor een ander deel Christen zijn geworden. 3 K.M. verder ligt Koninis, zoo genoemd naar een klein riviertje. Hier woont de Kapitan van de Mantanstreek als Onderdistriktshoofd.

Van deze plaats volgt men den loop der Boenta nog een 7 K.M.; dan steekt men de Bohotokon, die zelfstandig haar weg naar zee zoekt over, tot men te Bangkoehan komt. Bangkoehan is een uitgehold blok hout, waarop men seinen geeft, zooals dit vroeger werd gedaan om de menschen samen te roepen. Deze plaats ligt aan den voet van het gebergte, aan den oever van de Kaloembanga, die niet ver van dit punt ontstaat uit de samenvloeiing van een aantal rivieren: Kaloembangoe, Oeë Mea, Kaheas en Koempi. Van deze plaats gaan twee wegen uit: Het pad naar het Z.Z.W. voert naar Mantan, ,lang”, dat nog in de vlakte ligt. De naam zou het dorp hieraan te danken hebben, dat het in den ouden tijd uit een zeer lange rij huizen bestond. Nog is Mantan een van de grootste Loinang-dorpen, en samen met de dichtbij gelegen gehuchten Tondok (,,benteng”) en Binohoe ,georakeld zijn", ${ }^{1}$ ), is het geen onbelangrijk bevolkingscentrum.

Het tweede pad leidt naar het Z.O., eerst door een paar riviertjes, waarop een korte maar steile klim volgt tegen het gebergte op; dan is men in Tombongan, waar een school is. De afstand van Bangkoehan

1) Mobohoe is het keuren van een plek met het orakel, ohoe, of de plaats voor het doel goed is. 
hierheen zal niet meer dan $11 \frac{1}{2}$ K.M. bedragen. De naam Tombongan leidt men af van tombo, dat touw draaien uit rotan beteekent; voordat het dorp gesticht werd zou men dit werk op deze plek hebben gedaan; maar de afleiding is zeer onwaarschijnlijk. Tombongan bestaat uit twee gedeelten: Tombongan en Bahoe (de waroe-boom, Hibiscus tiliaceus). Het is een echt bergdorp. De huizen staan er in een lange rij op een smallen bergrug geschaard, aan welks eene zijde de Kaloembangoe en aan den anderen kant de Oeë Mea stroomt. Ten Z. van het dorp verheft zich de berg Tajojo.

Zes uur verder naar het Z.O. over het gebergte heen komt men aan Simpang. Dit woord duidt twee kruiselings in den grond gestoken stokken aan, maar men gebruikt het ook, wanneer bergen elkaar op deze wijze naderen en ontmoeten. Simpang is de naam van de streek. Het dorp dat zich daar bevindt, heet Kohoemmamaon. De inwoners van alle dorpen boven Bangkoehan zijn van Baloa hierheen getrokken.

Aan den benedenstroom van de Kaloembanga zijn nog een aantal kleine nederzettingen van Loinangs. Aan een andere rivier, de Bela, vindt men ze ook, evenals aan den benedenstroom van de Toimaa, die zich tusschen de Loboe en de Boenta een weg naar zee baant.

\section{De Loinangs.}

Ieder die nader kennis maakt met het volk der Loinangs, valt het aanstonds op, dat het uit twee deelen bestaat: de lieden van Lingketeng, Pinapoean en al de dorpen, waarheen deze menschen zich hebben verspreid; en de lieden van Baloa, Tanboenan, Mantan en Simpang. De eerste groep zal ik aanduiden met den naam van Lingketengclan, omdat zij dit dorp zooal niet voor het oudste, dan toch voor het voornaamste houden. De tweede groep noem ik de Baloa-clan; we zullen beneden zien, dat deze menschen eerst op andere plaatsen hebben gewoond, maar Baloa is dan toch de oudste van de nu bestaande nederzettingen. Vraagt men aan de inwoners van Tamboenan vanwaar ze zijn gekomen, dan antwoorden ze: „Van Baloa”. Zoo zeggen ook alle lieden uit de Mantan-streek in het bovenland van Boenta.

De eerste Europeaan, die de Loinangs bezocht, Dr. J. Wanner, geeft in zijn reeds genoemde reisbeschrijving de volgende aanteekening van de Lingketeng-menschen, naar aanleiding van het feit, dat men hem het doorreizen van deze streek wilde beletten: „Und so 
wird es wohl nicht leicht werden, dieses kräftige, rauhe und von einem starken Unabhängigkeitsgefühl beherrschte Volk, das mich übrigens in dieser Gegend in seiner gelblichen Hautfarbe, den etwas schiefstehenden Augen und auch in der Gangart an die japanische Rasse erinnerte, vom Gegenteil zu überzeugen und dauernd zu unterwerfen".

Dr. Wanner heeft geen gelegenheid gehad de menschen van Lingketeng met die van Baloa te vergelijken. Dr. W. Kaudern heeft het verschil tusschen de beide clans wèl gezien. Ofschoon de cultuur van beide groepen dezelfde is, zegt hij, verschillen de lieden van Tamboenan (Baloa) in voorkomen met die van Pinapoean en Lingketeng. De laatstgenoemde twee groepen zijn langer van gestalte, hebben kleine gezichten met rechte of eenigszins gebogen neus. Het Tamboenan(Baloa-)volk heeft aanzienlijk grovere trekken, breedere gezichten, en schijnen minder krachtig gebouwd. Kaudern houdt deze menschen voor het meest onvermengd.

Prof. Dr. W. E. L. Weck, gewestelijk arts van Manado heeft in 1925 de Loinangs van Boenta en Simpang anthropologisch onderzocht. Deze heer is zoo vriendelijk geweest mij toe te staan om de volgende aanteekeningen omtrent die onderzoekingen mee te deelen: „Ik heb ongeveer 30 volwassen mannen (te Simpang) gemeten. De vrouwen en kinderen kwamen namiddags; de vrouwen voelden niets voor de metingen, misschien minder omdat ze bang waren, ik denk meer uit verlegenheid. Bij de kinderen beperkte ik mij tot het gewone onderzoek naar miltindex enz. Ik vond een krachtige, en voorzoover ik de menschen gezien heb, gezonde bevolking, mooi en goed gebouwd lichaamsgestel, maar zeker een zuiver ras en niet gemengd met vreemdrassige elementen. lk denk ook niet dat deze menschen bij hetzelfde ras behooren als de man uit Nioeboelan, dien ik te Boenta nog meten kon. Hij toonde althans heel andere cijfers van schedelafmetingen dan deze menschen, terwijl ik te Simpang een zoo groote overeenstemming vond, dat de getallen bijna overeenkomen, zoo miniem is het verschil tusschen de gemeten personen, afgezien natuurlijk van het verschil in lichaamslengte en daarmede samenhangende afmetingen van de ledematen.

„Het verschil tegenover de bevolking van Bangkoean en de kampongs Tombongan Bahoe en Koninis is eveneens zeer groot. Niet alleen op raskundig gebied, maar vooral op hygienisch gebied. Terwijl boven te Simpang praktisch geen malaria is, heerscht in deze kampongs zeer zware endemische malaria. Alles wat ik uit deze kampongs 
te zien kreeg, was ziek, zonder uitzondering malaria; enkele frambosia-lijders heb ik met Neosalversaan behandeld".

Ik zelf heb ook ruimschoots gelegenheid gehad het verschil tusschen beide clans op te merken. Het meest trof mij dit te Tombongar. Daar was de goeroe met zijn gezin afkomstig van Lingketeng, en hij had nog vele familieleden van zichzelf en van zijne vrouw meegenomen, zoodat in de zeer ruime onderwijzerswoning een kolonie van lieden van I.ingketeng woonde. Hierdoor viel het verschil in gelaatstrekken van deze menschen met die van hun omgving bizonder duidelijk op. Onder de vrouwen van het Baloa-volk heb ik verscheidenen opgemerkt met Melanesische trekken en min of meer golvend, kroesend haar.

We mogen dus wel vaststellen, dat de Lingketeng-menschen voortgekomen zijn uit een vermenging van een oorspronkelijk daar gewoond hebbende tak van het Saloean-volk, dat zich over dat deel van Celebes' Oostarm verspreid heeft, en een volk van immigranten. Deze binnendringers hebben zich nagenoeg niet vermengd met de leden van de Baloa-clan, die we waarschijnlijk het zuiverst bewaard vinden in de lieden van Simpang, die ik echter niet heb ontmoet.

We zullen beneden zien, dat de Lingketeng-groep vorsten uit hun midden hebben gehad, die de Baloa-menschen niet hebben gekend. Deze omstandigheid is waarschijnlijk de voornaamste oorzaak geweest van de voortdurende schermutselingen tusschen de beide clans. De Baloa-menschen kenmerkt ook de groote schuwheid die hun eigen is, zoodat de lieden van Simpang nog niet onder geregeld bestuur zijn gebracht. Onder de inwoners van Baloa en Tombongan zag ik velen met denzelfden angstblik in de oogen, als ik zoo menigmaal bij de To Wana heb opgemerkt, die het westelijk deel van den Oostarm bewonen. In tegenstelling hiermee hebben de Lingketeng-menschen zich zonder slag of stoot aan het Gouvernement onderworpen, terwijl ze zich geredelijk hebben laten bekeeren tot het Christendom. Van het Baloa-volk kan dit alleen nog gezegd worden van de inwoners van Tamboenan en de van hier uitgezwermde lieden van Koninis. Enkele jaren geleden zijn de lieden van het dorp Baloa en bloc tot het Christendom overgegaan, en in Tembongan zijn thans ook enkele gedoopten. Maar overigens wil men in de Mantan-streek en in Simpang nog niets van het Christendom weten. Een poging die daartoe in het Mantan-gebied is gedaan, is mislukt.

Wanneer de menschen verhalen, dat hun voorouders van Boalemo zijn gekomen, hebben deze overleveringen alleen betrekking op de 
vreemdelingen, die zich later met een deel van het in deze streek wonende volk hebben vermengd. Dit blijkt uit verschillende trekken van die overleveringen zelf, waar ondersteld wordt, dat de immigranten in het binnenland menschen aantroffen. En in de tweede plaats blijkt dit uit de omstandigheid, dat de invasie nog niet zoo heel lang geleden kan hebben plaats gehad. De overleveringen spreken daartoe te duidelijk, de reeks van vorsten, die in Lingketeng hebben geregeerd is niet lang, terwijl ten overvloede de tijd der verhuizing nader bepaald kan worden door gegevens die we uit het Gorontalosche hebben.

We vinden ten opzichte van de Loinangs dus hetzelfde verschijnsel als bij de Toradja's: een oorspronkelijk, lager staand, volk dat niets weet van een land van herkomst, maar dat meent van het begin van de wereld af daar te hebben gewoond; en een geïmmigreerd, hooger staand, volk dat zich hier meer, daar minder innig met dat oorspronkelijke volk heeft vermengd, en dat de overleveringen van zijn herkomst bewaart, welke overleveringen ten slotte door de elementen van de oorspronkelijke bevolking ook als de hunne worden beschouwd.

\section{Herkomst van de Immigranten.}

Onze voorouders, zoo vertelde men mij zoowel in Pinapoean als in Lingketeng, komen van Ternate (waar dit ergens ligt, wist geen van de ouden te zeggen). Dit land werd door een grooten watervloed overstroomd. Toen was daar een man, Balajan genaamd, die een prauw hakte met een deksel, zoodat ze op een groote kist geleek. Daarin kroop hij met vrouw en kinderen, terwijl hij niets meenam dan wat pisang-spruiten en een njoeli-vogel (dit moet een soort parkiet of papegaai zijn, loeri, noeri). Zoo gaf hij zich aan de baren over, waarop de kist doelloos werd rondgedreven (een ander zei mij dat de man Kiamat, en de vrouw Alamat heette).

Nadat de kist zeven dagen had rondgezwalkt, lichtte Balajan het deksel op om te zien of er soms al land te bekennen was, maar hij zag niets dan water. Eindelijk na 14 dagen stootte de kist op land. Balajan lichtte het deksel af, en toen bleek dat ze te Malik op de kust van Boalemo waren. Aan land gegaan, liet hij den vogel los, en deze kwam niet terug, hetgeen hij aanmerkte als een gunstig teeken om op die plek te blijven wonen. Toen plantte hij de meegebrachte pisang-spruiten, en deze groeiden voorspoedig, zoodat ook 
dit een bewijs voor hem was, dat hij zich gerust op die plek kon vestigen. Balajan noemde haar Malik, omdat de vloed daar was teruggekeerd (mobalik). Dat het land aan den kop van Celebes' Oostarm Boalemo genoemd werd, komt omdat het zich aan Balajan voordeed als een boea lemo „lemoen-vrucht”. Balajan had een zoon, clie volgens sommigen Toembala heette, volgens anderen Sampalagading. Deze laatste naam doet onwillekeurig denken aan den Loewoeschen sageheld Sawerigading. Van Balajan's zoon weet de overlevering alleen te vertellen, dat hij een zoon en een dochter had: de eerste heette Lalogani, de tweede Mapaang.

Lalogani bezat een hond (dedeng), die alle wild, dat hij op de jacht nazette, ving. Mapaang had een vischarend (lensama), die er elken dag op uitging om visch te halen voor zijn meesteres. Eens leende Lalogani den vogel van zijne zuster, maar omdat de 'arend hem niet anders dan kleine visschen bracht, sneed hij hem in zijn boosheid de nagels af, zoodat het dier daarna geen visch meer kon srijpen.

In een andere lezing wordt verteld, dat broer en zuster een weddenschap aangingen wiens hakbord (padotan), waarop vleesch en visch aan stukken wordt gehakt, het eerst doorgehakt zou zijn door het drukke gebruik dat er van gemaakt werd; m.a.w. wiens dier het meeste ving, zoodat daar het hakbord ook het meest gebruikt moest worden. De vogel bleek het meest aan te brengen, en uit boosheid sneed Lalogani hem de nagels af. ${ }^{\mathbf{1}}$ )

Mapaang wilde daarom niet langer daar blijven, en ging naar haar man, den vorst van Loewoe. Ze riep de hulp in der Ternatanen om zich op haar broer te wreken, en deze lieden kwamen in talrijke prauwen naar Boalemo. De woonplaats Malik was echter goed versterkt met eenige omheiningen, zoodat het den Ternatanen niet gelukte naar binnen te dringen. Toen gebruikte men een list: in den nacht strooide de vijand een menigte zilverstukken om het dorp heen en tusschen de palen van de versterking, waarna hij zich terugtrok. Toen Lalogani en zijne mannen al dit geld op den grond zagen liggen, kwamen ze naar buiten om het op te rapen. Toen zagen ze dat ook tusschen de palen van de versterking veel geld lag. Om dit machtig te worden, hakten ze de benteng om. Toen kwam de vijand weer opdagen, en de inwoners van Malik moesten naar alle kanten vluch-

1) Dit verhaal is in verschillende deelen van Celebes bekend; o.m. wordt het verteld met betrekking tot de To Pajapi (de Barée sprekende Toradjas, [verder aan te duiden als Toradja's], I, 42). 
ten om niet in zijn handen te vallen. Lalogani sneuvelde, en de Ternatanen namen zijn hoofd en zijn hoofdbedekking van goud, totooemba mosoni geheeten, met zich mee. Mapaang eigende zich den heelen oorlogsbuit toe, als vergoeding voor de schade, die haar broer haar had berokkend.

Lalogani had vier zoons: Mamgamben, Tongkoi, Binelo en Lakaoeta, die zich naar verschillende kanten uit de voeten makten. Voordat we deze broers op hun zwerftochten zullen volgen, moet ik mededeelen, dat het deze katastrof op Boalemo moet zijn geweest, die ook een aantal van deze lieden naar Gorontalo 'bracht. De berichten die we hierover hebben, zijn afkomstig van Dr. J. G. F. Riedel (De Landschappen Holontala, Limoeto, Bone, Boalemo en Kattinggola of Andagile, Tijdschrift Bat. Gen., deel 19, 1870, bl. 123). Ik deel daarvan mede wat hier ter zake dient. Volgens overlevering woonde de bevolking van de landstreek Boalemo (Tilamoeta) in de onderafdeeling Gorontalo voorheen aan den overwal tusschen Patipati en Balantak. „Door Ternatanen en Tobeloërs bestookt, verhuisde ze naar dit gedeelte van de Tominibocht, en stelde zich onder bescherming van Holontalo en Limoeto. Vervolgens door de Limoetosche hoofden als slaven bejegend wordende, vertrok in 1787 hun opperhoofd Paloa naar Ternate om zich te beklagen en hulp bij de Nederlanders te erlangen. Te Ternate legde hij den eed van trouw aan de Kompagnie af."

„Toen in 1790 de gouverneur der Molukkos, Alexander Cornabe, te Holontalo was, werd in eene deswege gehouden vergadering de zelfstandigheid van Boalemo erkend, en beval hij de radja's van Holontalo, Limoeto, Bolanga, Bone en Kattinggola aan om de Boalemoërs, welke 's Kompagnies bescherming hadden ingeroepen, niet te onderdrukken".

Uit dit bericht blijkt duidelijk, dat we ten opzichte van deze Boalemoërs niet te doen hebben met uitgewekenen, maar met krijgsgevangenen. Aan de expeditie die Malik ten val bracht, hebben ongetwijfeld veel Gorontaleesche Hoofden deelgenomen. Gorontalo stond geheel onder invloed van Ternate, en het is bekend, dat twee eeuwen geleden meermalen Ternatanen en Gorontaleezen gezamenlijk strooptochten in de Tominibocht ondernamen. De Boalemoërs die we in het Gorontalosche vinden, kunnen wel niet anders dan krijgsgevangenen zijn geweest. Vandaar dat ze door de Gorontaleesche Hoofden als slaven werden behandeld.

In 1893 heeft de toenmalige Officier van Gezondheid A. E. H. 


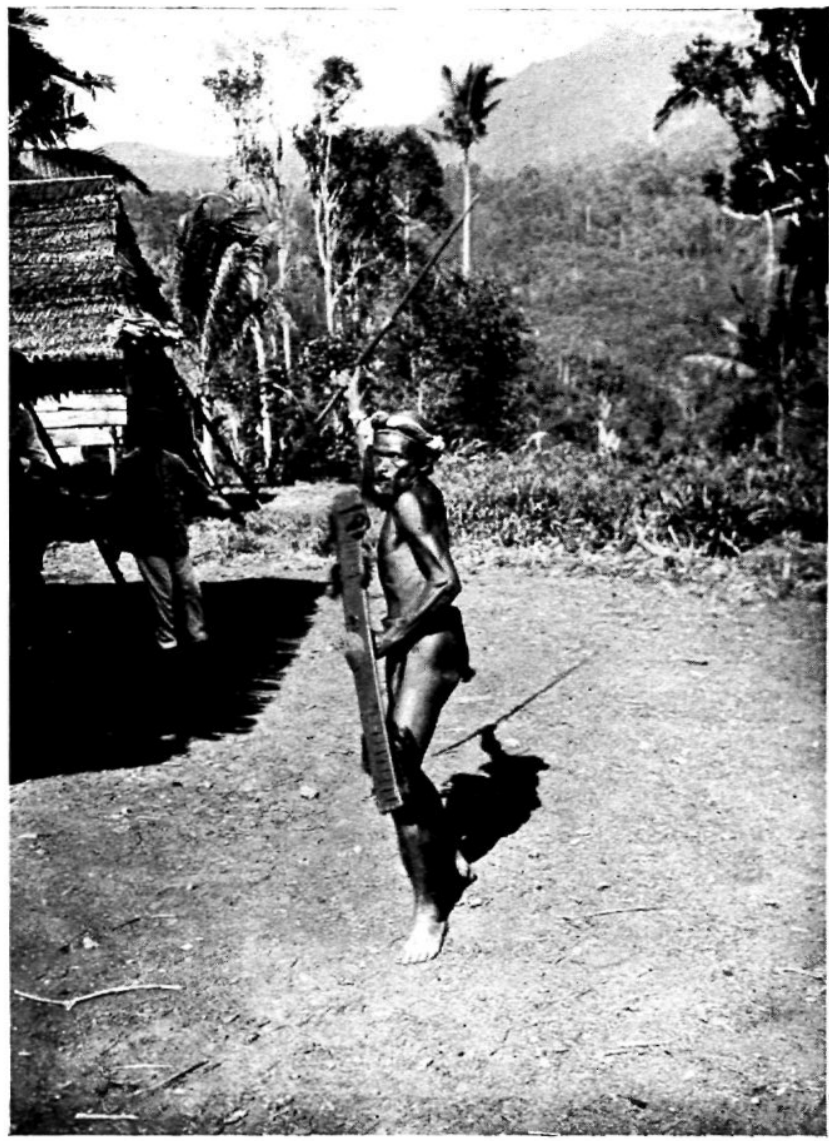

Een man van Simpang met het krijgsversiersel, soealang, op het hoofd, den krijgsdans uitvoerende (oemapos) (foto W. E. C. Veen, Ass.-Res.)

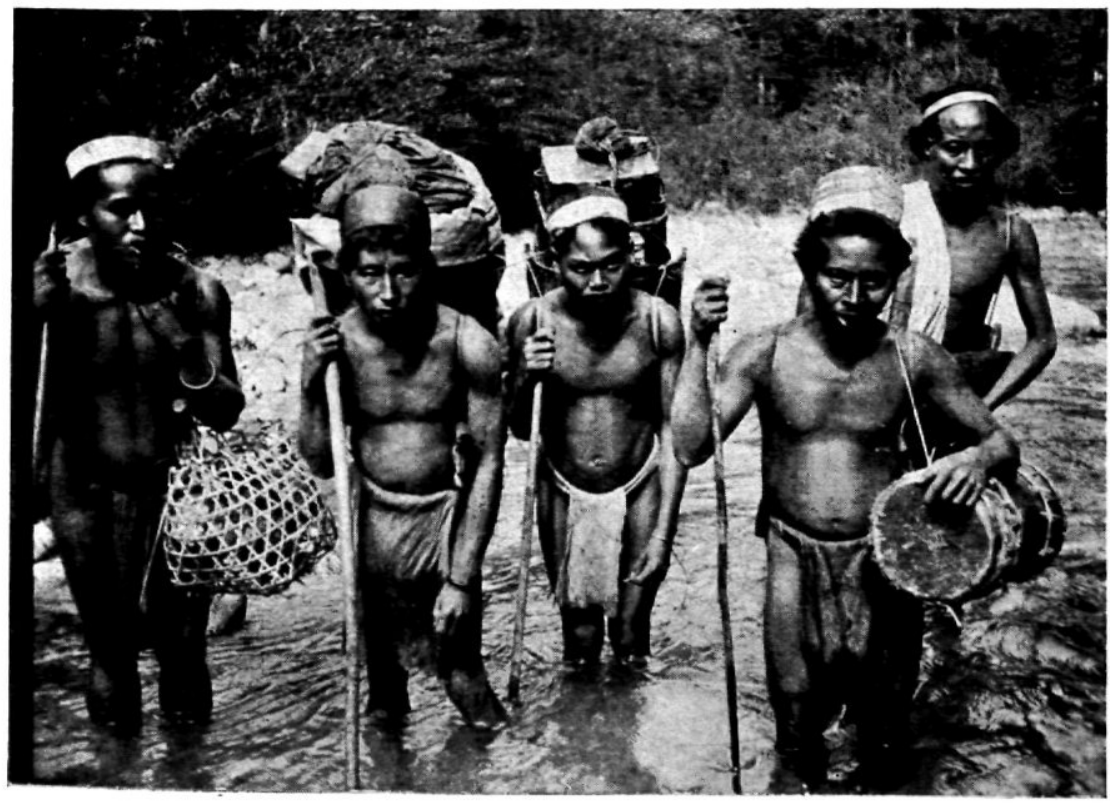

Een groep mannen van Simpang, een rivier doorwadende (foto W. E. C. Veen, Ass. ARes.tccess 
Lubbers in Geneeskundig Tijdschrift voor N.-I., dl. 32 (1893) de resultaten van zijn anthropologisch onderzoek gepubliceerd: „Eene bijdrage tot de Anthropologie der bevolking in de Assistent residentie Gorontalo (residentie Menado)". Lubbers merkt op, dat een merkbaar verschil bestaat tusschen de inwoners van de distrikten met een groote kustlijn, en die van de meer naar het binnenland gelegen distrikten. Terwijl de eerste groep 80-88 pCt. subbrachyceph. + brachyceph. bevat, heeft de laatste groep $50-65 \mathrm{pCt}$. Lubbers schrijft dit toe aan de omstandigheid, dat de vreemdelingen, die door de tijden heen in het Gorontalosche kwamen wonen, zich het meest in de kustdistrikten hebben gevestigd.

Wat nu Tilamoeta betreft, de streek die door de Boalemoërs is bevolkt, sluit dit zich met zijn index van 84.0 aan bij de distrikten met kustlijn, maar verschilt er van door zijn lengte-diameter van 176 en breedte-diameter van 148. „Het hoofd is kleiner in beide demensies; waarschijnlijk hebben wij hier dus te doen met eene andere vestiging dan in de overige kustdistrikten. Volgens den Heer Riedel is Tilamoeta bevolkt door Boalemoërs, die in 't midden van de 18de eeuw van den overkant van de Bocht van Tomini verhuisden.... Het is opvallend dat dit distrikt in zoo korten tijd anthropologisch zulk een verandering heeft kunnen ondergaan. Onder de Inlanders van Batoedaa leeft de traditie, dat zij voor een groot deel afstammen van de Boalemoërs, en het is een feit dat velen uit Batoedaa naar Tilamoeta $(=$ Boalemo) gaan of omgekeerd om een vrouw te halen. De indices cepalic van Batoedaa en van Tilamoeta staan wel is waar vlak naast elkaar, maar de lengte- en breedte-diameters van Batoedaa zijn resp. 179 en 151, tegenover 176 en 148 in Tilamoeta. Er bestaat dus wel degelijk een verschil, dat òf toe te schrijven is aan de tijdelijke vestiging der Boalemoërs in Batoedaa, òf aan het verblijf van een ander volk met een groote D transvers van het hoofd, want er bestaat een duidelijk merkbaar verschil tusschen de kampongs, die niet ver van de kust, en die ver van de kust, en die, welke dieper het binnenland in liggen".

$\mathrm{Na}$ deze uitweiding kan ik het verhaal vervolgen van de wederwaardigheden van Lalogani's zonen. Slechts van twee hunner worden de omzwervingen medegedeeld, maar ook in deze verhalen is verschil op te merken. De kapitan van Lingketeng vertelt als volgt: Mangamben en Tengkoi waren ieder op zichzelf naar het Westen gevaren. Toen de laatste nabij Kaap Djapara voorbij Pangimanan D1. 86 . 
was gekomen, liet hij alle goederen, die hij nog mee had kunnen nemen, in zee vallen, om zijn prauw te verlichten, omdat hij bang was, dat de Ternatanen hem nog zouden inhalen. Die goederen bestonden uit: 8 stukken sakalati (een soort oud en duur katoen), 8 st. patola (soort weefsel), 8 schilden van koelaloe (tin), 8 speren (talombo), 8 zwaarden (badjak), 8 sepen koclaloe (groote borden van tin). Mangamben behield de goederen, die hij had meegenomen. Dit is de reden, waarom de nakomelingen van den eerste arm, en die van de laatste rijk zijn.

De eerste plaats die Mangamben en de zijnen aandeden, was Pangimanan: ze pruimden daar sirih (nomangan), en daaraan heeft die plek haar naam te danken. Vandaar ging men naar Tongko noenoe: daar kauwden zij suikerriet (montö toemba), en daarom heet die plek tot op heden Ntoë toemba. Aan de monding van de Pooehoea praatten de reisgenooten met elkaar (binahooe), wat ze nu zouden doen: vandaar dat die plaats Pooehoea heet. Hier verlieten de vluchtelingen hun vaartuig, en trokken langs de genoemde rivier het binnenland in.

Het eerste dorp maakte Mangamben aan de Boengka, een klein zijriviertje van de Pokooeha. Van hier trok hij naar de Totopan lai, een berg. Daarna verhuisde hij naar de Binti, een riviertje dat in de Mendono valt (men was dus al aan de overzijde van de waterscheiding gekomen). Van de Binti kwamen ze naar den berg Tonii, waar de Kintom-rivier langs stroomt. Deze stroomafwaarts volgende kwamen ze tot de rivier Tongkea en van hier naar Laboengkoe. Op deze plek ontmoette Mangamben een hoofd (bobato) van Banggai, en deze stelde hem aan als Sengadji van Kintom.

Te Pinapoean vertelde men eenigszins anders: Mangamben zou namelijk met zijn prauw te Kintom zijn gekomen: hij moet dan den kop van Celebes' Oostarm om zijn gevaren. Op die plek gekomen plantte hij den stok (pentokon), waarmee hij zijn prauw had voortgeboomd, in den grond, en daarnaar zou die plek Kinton heeten.

Tongkoi voer de Pokooeha voorbij naar de monding van de Loboe. Daar liet hij palmiet van de rotan snijden, die oboe heet, 'om deze als toespijs bij de rijst te gebruiken, en hieraan heeft de rivier haar naam te danken. Een ander verhaal zegt, dat Tongkoi stukken oboe in de rivier vond, die blijkbaar door menschen waren afgesneden; hij maakte daaruit de gevolgtrekking, dat er menschen bovenstrooms woonden, en hij besloot naar boven te gaan om ze op te zoeken. Tot aan den berg Toenggoenjo gekomen, bleef hij daar eenigen tijd om 
het vogelgeluid te beluisteren (mompihongoi) om daaruit op te kunnen maken of de Ternatanen hem nog volgden of niet. Van hier voort getrokken vestigde hij zich te Bintonoe, een plek tusschen de Sensean-rivier en den bergrug van Lingketeng gelegen (hij was dus uit het ravijn van de Loboe de Sensean stroomopwaarts getrokken). Van hier uit moeten dan de verschillende dorpen zijn gesticht, eerst Netes, op denzelfden bergrug waarop Lingketeng ligt, vervolgens Lingketeng zelf en andere dorpen. ${ }^{1}$ )

$\mathrm{Er}$ is nog een verhaal, waarin gezegd wordt, dat de beide andere zoons van Lalogani, Binelo en Lakaoeta, met Tongkoi mee zijn gegaan. De eerste stichtte het dorp Indang, en van hem zouden de menschen van Pinapoean afstammen. Lakaoeta bleef aan den bovenloop van de Pokooeha, en zijn nakomelingen zijn de lieden, die die streek en de kuststrook bewonen.

Tongkoi ging van Bintonoe uit veel op de jacht. Eens werd hij door den nacht overvallen, terwijl hij nog een heel eind van huis was. Toen zag hij in de verte een vuur branden. Hij plantte een stok in den grond, waarmee hij den volgenden morgen de richting zou kunnen bepalen, waarin hij het vuur had gezien. Toen de dag was aangebroken, liep hij dien kant uit. Zoo kwam hij te Banta (de lieden van Banta wonen nu in Kolomboi). De menschen die hij daar aantrof, spraken een andere taal, maar men verstond elkaar toch. Die lieden voedden zich uitsluitend met knolvruchten, die zij niet eens wisten toe te bereiden. Tongkoi overviel hen, maar hij sloot vriendschap met ze, en men sprak een dag af, dat de menschen van Banta naar Bintonoe zouden komen, en dan zou Tongkoi hen rijst en andere nuttige gewassen leeren planten. Dit gebeurde en

1) Volledigheidshalve vermeld ik een verhaal, dat Kaudern in zijn boek heeft opgenomen uit een patrouille-rapport, dat hij in het archief te Loewoek vond. Volgens dit verhaal zouden de lieden van Lingketeng afstammelingen zijn van drie matrozen, die gered zijn van een vaartuig, dat bij Tandjong Api verloren ging. Als bewijsgrond voor dit bericht wordt vermeld dat de lieden van Lingketeng graag korte pijpen rooken, zooals zeelui dit vaak doen. Verder zouden er verbasterde Hollandsche woorden in hun taal voorkomen, zooals Lingketeng „lange ketting”, daar hun voornaamste dorpen op een rij op een langen bergrug liggen. Verder zou de huidskleur opvallend licht zijn. Kaudern hecht terecht aan deze fantasie geen waarde. Bij navraag vond Kaudern, dat niemand iets van zoo'n overlevering afwist. Maar toen ik er nu hier en daar over sprak is mij gebleken, dat Europeanen al meermalen naar dit verhaal navraag hebben gedaan; en als dit nog een poos zoo voortgaat, gaan de Loinangs zelf aan de waarheid van het verhaal gelooven, en disschen zij het zelf aan bezoekers op. 
sedert dien zijn de menschen van Banta aan Lingketeng onderworpen.

Op een van zijne jachttochten ontmoette Tongkoi zijn broer Mangamben, die van Kintom uit het gebergte ingetrokken was om te jagen. De beide broers herkenden elkaar niet, hielden elkaar voor vijanden, en wilden elkaar te lijf. De een zeide: Weet je niet dat ik cen afstammeling ben van Boalemo? „En de ander trachtte de tegenpartij te intimideeren met de woorden: „Nu zult ge eens zien, of ik geen zoon ben van Lalogani!" Uit deze woorden begrepen ze, dat ze broers waren, en in stede van met elkaar te gaan vechten, hernieuwden ze de kennismaking. De beide broers ruilden nu als teeken van vriendschap hun vuurslag (potinding) met elkaar, en daarom heet die plek op den berg Omponan, waar ze elkaar ontmoetten: Kolongan petinding, ,stuk van een vuurslag”.

Mangamben zei tot Tongkoi : „Breng mij een kaliding (een soort mand) met rijst naar Tonii, dan geef ik u daarvoor boonen (boë̈). 'I'oen Tongkoi zoo'n kaliding vol rijst naar de andere zijde van het gebergte had gebracht, vond Mangamben, dat een kaliding te klein was, en hij eischte een besi vol, d.i. een vat van sagogladscheede gemaakt (popa oe ladang). Hieruit is langzamerhand de toestand ontstaan, dat de oudere broer, Tongkoi, aan den jongere, Mangamben, schatting of hommage moest opbrengen. Hierop komen we beneden terug.

Tongkoi gaf het aanzijn aan het geslacht der vorsten van de Loinangs, die den titel voerden van daka'njo ,de groote”. De zoon van Tongkoi was Babinto. Deze kreeg drie zoons: Kamboa, Momping en Pedan. Kamboa kreeg weer drie zoons: Besa, Idjam en Doempapa. Besa gewon Mondjawap en eenige dochters. Mondjawap was de vader van den huidigen kapitan. Wanneer wij den leeftijd van den laatste op 55 jaar stellen, en voor elk geslacht 25 jaar rekenen, komen we op 155 jaar. Naar deze berekening zou Tongkoi als 25-jarig man ongeveer in 1777 in dit land zijn gekomen. Deze berekening komt overeen met wat wij uit de geschiedenis van Gorontalo weten.

De machtigste van deze Hoofden is Kamboa geweest. Zijn lijk werd niet begraven, maar in een kist op een rots geplaatst buiten het dorp Lingketeng. Zijne beenderen worden nog steeds vereerd. Ik kom hierop later uitvoerig terug.

Een waardigheid welke op die van daka'njo volgde, was die van tonggol (zooals ik reeds heb opgemerkt, zegt men in het binnenland 
tonggon). De voornaamste van deze tonggol was die van Pinapoean, die afstamt van Tongkoi's broer Binelo. Deze had een zoon, Ponsasap geheeten, wiens zoon Liapong huwde met Tina, een dochter van Tongkoi. Dit paar kreeg een zoon Pohae; deze woonde te Padoengnjo, waar ook zijn graf is, maar zijn dorp was Hejoeha; hij sneuvelde te Bete'o aan den overkant der bergen. Een zoon van deze was Olibaja, die met Salilaja huwde, en een zoon kreeg, Biniloe geheeten. Deze Biniloe zou Indang hebben gesticht, maar hij verhuisde later naar Boehangas, waar hij stierf. Een broer van hem, Pogajaman geheeten, stierf te Kintom bij gelegenheid dat men schatting daarheen bracht.

Biniloe had vier zonen: Pasawe, die te Palaoekan in 't gebergte woonde, Boloeloeng, Doemondon en Mogoembali. De eerste en de derde werden geen tonggol; de tweede en de vierde wel. Mogoembali volgde zijn broer in dit ambt op, omdat de eerste geen zoon had. Mogoembali stichtte Sopa, en nadat hij daar 5 jaar had gewoond, stichtte hij Doija boengin, dat tijdens het bestuur van zijn zoon Loembajang verbrand werd, waarna deze streek voortaan Pinapoean werd genoemd. Deze tonggol werd weer vervangen door Lalangi, die in November 1919 overleed, en door Talahata werd opgevolgd, het tegenwoordige Hoofd van Pinapoean.

Behalve in Pinapoean stelde de daka'njo nog tonggol aan te Banta (thans Kolomboi), te Soloedoek, waarvan de inwoners eerst naar Tabangian, en daarna naar Sinampangnjo, dicht bij Pangimanan verhuisden; te Kaaboeng aan het Westelijk uiteinde van den Lingketeng-bergrug, waarvan de inwoners naar de Toimaa-rivier zijn verhuisd; te Tabango, te Babang en te Tina'an, alle plaatsen in het Kintomsche; ten slotte was er nog een te Oedjoela'an, dicht bij Poh.

De macht van den daka'njo strekte zich uit over alle Loinangs tot aan de zee; in Loboe en Pangimanan woonden toen nog geen menschen. Naar het Zuidwesten ging zijn invloed tot de Solo poenda, zoodat de heele Baloa-clan er buiten viel. Aan de andere zijde van de waterscheiding behoorden de dorpen Tina'an en Tabalon, boven Kintom, nog tot zijn machtsgebied, dat liep tot Mahenge.

Toen het Gouvernement bezit nam van dit land, wilde het, dat de Sengadji van Kintom naar Loboe zou verhuizen, omdat de aan hem onderhoorige Loinangs niet over de waterscheiding heen konden worden bestuurd. Maar hiernaar had deze functionaris geen ooren. Hij droeg dus zijn macht over aan Mendono. Dit is een plaats, die niet ver van Kintom afligt, en waarvan de inwoners aan die van 
Kintom verwant zijn. Mendono had al een nederzetting te Lembangan aan de Tominibocht, 3 K.M. van Pangimanan, en zoo werd de Sengadji van die plaats het Hoofd der Loinangs. Als onderdistriktshoofd of kapitan fungeerde het Hoofd van Loboe (een Gorontalees), maar later werd de voormalige daka'njo der Loinangs hun Hoofd, terwijl die van Loboe zijn macht over de kuststreek uitoefent. De kapitan van Lingketeng (hij woont echter te Bahingin) heeft aan gene zijde van de waterscheiding niets meer te zeggen; daarentegen behooren Tamboenan en Baloa met hunne gehuchten tot zijn machtssfeer. Het distrikt waartoe de Loboe-Loinangs behooren, heet thans Mendono.

\section{De Immigranten van Baloa.}

Omtrent de lieden, die de menschen van Baloa hebben voortgebracht, bestaan twee overleveringen. De eene vernam ik van Jakob Koetondong (alias Lalekang), de woordvoerder der Baloa-menschen; de ander werd mij verteld door den kapitan van Lingketeng, dus door iemand, die niet tot de Baloa-clan behoort. Beide verhalen bevatten merkwaardige trekken. Ik begin met het verhaal van den Kapitan.

Er leefden eens drie broers samen op den berg Baloembe'a, ten Westen van de Loboe-rivier, dicht bij de zee. Deze mannen heetten: Daeng, Mintoedoe, en Kadangaan. Dit waren echte boschmenschen, en niemand weet, vanwaar ze gekomen waren. Op een goeden dag kwamen Tobeloreezen aan het strand, en dezen doodden Daeng. De beide broers namen hierover wraak door de prauwen der Tobeloreezen te verbranden. Dezen konden nu niet meer naar hun land terugkeeren, en ze trokken daarom het binnenland in. Ze vestigden zich eerst te Tahian Soealang ten Westen van den berg Lokait. Vandaar verhuisden zij naar Totap bonoea, in de buurt van de vorige plaats, en ten slotte gingen ze naar Lontojon, dicht bij het tegenwoordige Baloa. Daar bleven ze en vermenigvuldigden zich.

De twee broers begaven zich van Baloembe'a naar Mata noe ampa, het latere Banta, tusschen Tamboenen en Lingketeng. Zooals boven verteld is, verraadden deze lieden hun aanwezigheid door het vuur, dat Tongkoi zag (anderen beweren, dat het Tongkoi's zoon Babinto was, die hen ontdekte).

Het verhaal van Jakob Koetondong gaat terug tot Boalemo. De Tobeloreezen waren daar gekomen, maar ze waren niet in staat de sterkten in te nemen. Toen strooiden ze zilverstukken om de 
benteng, waarvan vele in het daar groeiende hooge gras vielen. Om zich snel daarvan meester te maken, brandden de lieden van Boalemo het gras af ; maar het vuur tastte ook het dorp aan, dat in de vlammen opging. Toen vluchtten de menschen.

Eenige gezinnen dezer vluchtelingen kwamen terecht te Awok bij de Hako-rivier. Maar op een goeden dag kwam een ontelbare menigte zeeslakken ( $\mathrm{see}$ ) opzetten, en vulde de huizen. Overal drongen ze in door, zoodat de menschen het niet konden uithouden. $\mathrm{Ze}$ vluchtten nu naar Tandjong Api; maar nauwelijks hadden ze hun huizen daar klaar, of ze hadden een aanval te doorstaan van zwaardvisschen (mantaoen), zoodat ze genoodzaakt waren weer weg te trekken. Ze gingen Oostwaarts. Dit waren twee gezinnen, een met zes en een met drie kinderen. Te Lialiatongon tusschen Boenta en Tobolombang gingen de twee gezinnen uiteen. Dat met 3 kinderen ging langs het strand tot aan de monding van de Loboe. Ze wilden naar hun vroegere nederzetting Awok terugkeeren, maar ze eindigden met een dorp te maken te Balanga, dicht bij de Loboe. Van daar trokken ze naar Oeë Manoek. Jakob beweerde den kokosboom nog gezien te hebben, dien de voorvaderen daar geplant hadden. Van hier trokken ze nog verder naar binnen tot Kompanga, dicht bij Baleang.

Het gezin met de zes kinderen trok van Lialiatongon dadelijk verder het binnenland in, en vestigde zich te Kolioeang, een eindje boven het huidige Baloa. Deze menschen kenden de rijst nog niet, maar ze aten kosi (Colocasia) en laboe (Lagenaria vulgaris). Beide gezinnen wisten niets van elkaars wedervaren af. Geruimen tijd daarna zagen de nakomelingen van het gezin van drie kinderen houtspaanders in 'de rivier afdrijven, zoodat ze begrepen, dat er bovenstrooms menschen moesten wonen. Ze beklommen nu de Soele manoek (,hoenderhart”), een bergje tusschen Lingketeng en Tamboenan in gelegen. Daar zagen ze een cuscus in een boom zitten; ze klommen het dier na om het te vangen, en toen ze boven in den boom waren, zagen ze rook in de verte. Ze trokken nu verder, de Loemoet-rivier over. Toen kwamen ze bij een verhakking in het bosch, en nog verder doordringende, zagen ze menschen, die bezig waren het merg van den arenpalm uit te hakken om er sago van te winnen. Dit werk heet oemonoenang, en daarom heet het riviertje, aan welks oever men dit deed, tot op den huidigen dag Onoenang. Onopgemerkt trok men verder tot men aan een poeloli-boom kwam, die juist door eenige mannen was geveld. Zoodra dezen de bezoekers hadden opgemerkt, 
wilden ze het op een loopen zetten. De anderen riepen hen toe niet bang te zijn, en wonderlijk: men verstond elkaar dadelijk, men had dezelfde taal!

Het heele gezelschap mannen bleek slechts één hakmes te bezitten, waarmee ze om beurten in den boom kapten. Toen beide partijen wat op hun gemak met elkaar waren gekomen, vertelden ze elkaar hun wederwaardigheden, en toen bleek al spoedig dat ze aan elkaar verwant waren, want dat de bewoners van beneden afstammelingen waren van het gezin met drie kinderen, terwijl de anderen behoorden tot het gezin met de zes kinderen. Die van beneden vroegen aan de pas gevondenen: „Wat is uw dagelijksch voedsel?” De anderen noemden op: „Pompoen, keladi, larven en honing” (de was gooiden ze weg). Hun bloedverwanten van beneden beloofden hen nu rijst en hoenders, kapmessen, garen, katoen en naalden te zenden. Maar, voegden ze er aan toe, ,als het gewas gelukt, en de hoenders zich vermenigvuldigd hebben, moet ge ons elk jaar kippen en was geven". Dit beloofden de binnenlanders graag.

De afstammelingen van het gezin met drie kinderen gingen van Kompanga naar Tohoekoe, een plaats die aan het zeestrand moet gelegen zijn, tusschen Toimaa en Boenta. Het Hoofd van die clan had drie zoons: de middelste werd sengadji, de oudste werd talenga (legeraanvoerder) en vervolgens daka'njo, met den titel van daka'njo Awok, ofschoon hij niet meer op die plek woonde; en de jongste kreeg den titel van meniboeloeak, en bleef te Awok wonen. De Sengadji ging naar Tangkian aan de Molukkenzee om vandaar uit de Baloa-clan te besturen. Hij zou zijn verhuisd, omdat men anders door het gebied van de Lingketeng-menschen, dus door vijandelijk terrein, zou moeten trekken om bij zijn heer aan de Tominibocht te komen. De daka'njo Awok ging te Boenta wonen. Zoo komt het dat men zijn rechtstreeksch hoof! te Boenta had, maar de heer des lands ver weg in Tangkian woonde. Volgens mijn zegsman Jakob aten twee geslachten sengadji nog varkensvleesch, en de tegenwoordige Sengadji zou uit het zevende geslacht zijn. Wanneer we elk geslacht op 25 jaar stellen, zou het hier medegedeelde hebben plaats gehad 150 à 175 jaar geleden, wat weer goed overeenkomt met de reeds genoemde gegevens van de Lingketeng-clan en van Gorontalo.

Behalve Baloa en Tamboenan behooren Kohoemamaon (Simpang), Mantan, Tombongan en de dorpen in de Boenta-vlakte alle tot de Baloa-clan; verder Hoombola en Kajoa boven Batoei (aan den anderen kant van het gebergte). Na de komst van het Gouvernement 
heeft Tangkian geen bemoeienis meer met zijne vroegere onderdanen. Baloa en Tamboenan behooren nu tot het distrikt Mendono; Simpang, Tombongan en de Mantan-streek en Koninis en wat verder aan Loinangs in de Boenta-vlakte woont, staan onder den Sengadji van Boenta. Het heele distrikt heeft echter den naam van Tangkian gekregen.

Bij de Berg-Toradja's van de onderafdeeling Poso, en ook bij de Toradja's van Poso en van de Westgroep bestaan verhalen, waarin verteld wordt van dorpen, welker inwoners de geesten hadden vertoornd, zoodat hun huizen gevuld werden met millioenenpooten en ander ongedierte, waardoor de menschen gedwongen waren hunne haardsteden te verlaten; ze trokken toen naar Loindangi. Altijd wanneer er sprake is van naar een ander land trekken, dan is het naar Loindangi. De verhalen, waarin ongedierte menschen verjaagt, moeten heel oud zijn. Zooals we zagen worden ze niet gevonden bij de moderne Lingketeng-clan, maar wel bij de meer oorspronkelijke Baloa-menschen. Historische waarde is dunkt mij niet aan die overleveringen te hechten, tenzij de gelijkheid der bizonderheden haar grond vindt in de omstandigheid, dat de oorspronkelijke bewoners van Celebes' Oostarm en die van Midden Celebes, dat thans door de Toradja's is bezet, tot eenzelfde volk hebben behoord. Hiervoor zou ook pleiten de omstandigheid, dat bij alle verschil in taal, zeden en gewoonten, sommige treffende gebruiken, en enkele belangrijke woorden overal op Celehes dezelfde zijn. In den loop van mijne mededeelingen is er gelegenheid hierop te wijzen.

Ik hoorde ook nog een overlevering vertellen, waarin sprake is van een Hoofd van Kolioean, wiens kinderen de stamvaders werden van eenige onderclans: de oudste ging naar Tamboenan, de tweede werd de stamvader van de lieden van Lontojon, die later in Baloa gingen wonen. Een derde trok over het gebergte naar Bolonoean boven Tangkian, en een dochter werd uitgehuwelijkt aan Lingketeng. Dit verhaal luidt als volgt: Het Hoofd van Kolioean ging met zijn dochter Pomboloa naar de Pokooehan-rivier om kookpotten te koopen. Onderweg werd de man door Babinto, de zoon van Tongkoi, gesneld, en Babinto nam het meisje in huis, en behandelde haar als zijn vrouw. Het duurde niet lang of het Baloa-meisje werd zwanger. Toen zeide Babinto tot zijne overige reeds volwassen kinderen: „Wanneer Pomboloa van een meisje bevalt, zal $u$ dit tot slavin zijn; maar is het een jongen, beschouw hem dan als mijn zoon. Dan moet ge zijn moeder, wanneer ik gestorven ben, naar Baloa terugbrengen". 
Het kind was een zoon. Toen brachten de kinderen van Babinto een slaaf en een kanon (lela) naar Baloa, als bloedschuld voor het dooden van Pomboloa's vader, en een mand (baki) met twee streng kamagi (zeer kleine ringetjes met golvende randen van goudbrons, die aan een snoer zijn geregen), 4 stukken tobila-katoen, 5 vadem gadja-katoen, als bruidsschat voor Pomboloa. De zoon van Pomboloa was Kamboa, de grootste daka'njo van de Lingketeng-clan. - Alle lieden uit het Lingketengsche, die ik naar de juistheid van deze overlevering vroeg, ontkenden de waarheid er van.

Een andere zoon van Kolioean's vorst heette Bikasi. Deze vestigde zich te Banka oe nioe, beneden Doehian. Deze gewon Djingkalap, wiens zoon Lambeng was; deze kreeg Mojajang, wiens zoon Mohege heette, en diens zoon weer was Simpaga. Simpaga kreeg Koetondong, de vader van mijn zegsman Jakob.

Ook de tonggol van Pinapoean zou van Baloa afstammen, en wel door een dochter van Ondoloe; maar ook dit wordt door de Lingketeng-clan ontkent. De Lingketeng-menschen zeggen niets met de lieden van Baloa gemeen te hebben.

In lateren tijd hebben zich plaatselijk nog andere elementen met het Baloa-volk vermengd. Zoo is het bekend, dat er lieden van Lontio, tusschen Loeok (Loewoek) en Kintom zich in het Baloasche hebben gevestigd. Men kwam hier om handel te drijven, maar men bleef. Zoo deden ook lieden van Makolong boven Batoei.

Dat de Baloa-clan in veel mindere mate met immigranten vermengd is, blijkt ook uit de omstandigheid, dat ze nooit gezaghebbende Hoofden hebben gekend. In Baloa, Mantan en Tamboenan waren mian kopian ,vredestichters” (mengkopian is ,vredestichten” tusschen twistende partijen). En verder luisterde men naar den talenga, den aanvoerder in den strijd. In Tamboenan moet ook een tonggol zijn geweest, maar de berichten hierover zijn zóó vaag, dat het vermoeden rijst, dat men deze inste!ling heeft overgenomen van het Lingketeng-volk.

Wanneer wij alle berichten samenvatten, komen we tot het besluit, dat de Oostelijke helft van het Oostelijk schiereiland van Celebes oorspronkelijk bewoond was door een primitief Saloean-volk, waarvan ten opzichte van de Loinangs, de menschen van Simpang een onvermengd overblijfsel zijn. In Boalemo had zich door immigratie van uit het Oosten een rijkje gevormd, dat om de eene of andere reden het ongenoegen had opgewekt van den Sultan van Ternate, die het met de hulp van Tobeloreezen en Gorontaleezen ging tuchtigen; dit gebeurde in de tweede helft van de 18de eeuw. Deze 
expeditie moet geweldig hebben huisgehouden onder de menschen, zoodat de lieden van Boalemo naar alle kanten een goed heenkomen zochten. Enkele afdeelingen van dit volk, dat een hoogere trap van beschaving bezat dan het oorspronkelijke volk der Saloeans, zochten een toevlucht aan de Z.uidkust van het schiereiland, en bleven daar wonen, waarschijnlijk omdat ze zich dadelijk onder bescherming van den Sultan van Banggai stelden. Andere afdeelingen vluchtten naar de Togian-eilanden, vooral naar Walea, en naar den vasten wal van de Tomini-bocht. Met kleinere en grootere partijen trokken ze op verschillende plaatsen het land in, waar ze zich meer of minder intens met de daar reeds aanwezige menschen vermengden. Op de eene of andere wijze kwamen deze lieden al spoedig in aanraking met hun vroegere stamgenooten, en aangezien zij die aan de Zuidkust waren blijven wonen, veel meer wisten en wereldwijzer waren dan de in het binnenland wonende lieden, ontstond hieruit spoedig een verhouding van heer en ondergeschikte, die in de hand gewerkt werd door het aanzien, dat de Sultan van Banggai aan de Hoofden van deze nederzettingen aan het strand verleende. De titel van den Sultan van Banggai luidt bij de Loinangs Tomoendo i Banggai.

Ten slotte moet ik nog even mededeelen wat de Kapitan van Mantan mij vertelde. Ik moet echter opmerken, dat hetgeen deze man mij vertelde, en waarvan ik niet alles zal weergeven, er blijkijaar geheel op ingericht was om te bewijzen, dat hij eigenlijk het ware stamhoofd der Loinangs is. Hij is, evenals alle lieden van Mantan, afkomstig van Baloa. Volgens hem dan zouden zijne voorouders van Boalemo gekomen, te Pada oelojo bij Tandjong Api hebben gewoond. Daar werden ze bestookt door twee vischsoorten mantocan en sce. Ze makkten water kokend, en begoten daarnee de zee. Hierdoor stierven de visschen en er ontstond zoo'n stank, dat men wegtrok. De eene broer ging de Bongka-rivier op tot Watoe moana (het woongebied van de To Wana dus), en vandaar over het gebergte naar den berg Toempoe, en verder naar Baloa. De andere broer trok langs het strand, en vervolgens de Loboe-rivier op. Dan volgt de reeds medegedeelde ontmoeting. Dit verhaal is alleen merkwaardig, omdat het spreekt van een trekken van het brongebied van de Bongka naar dat van de Loboe. Wanneer in deze overlevering een kern van waarheid zit, dan moet het deze zijn, dat het volk waaruit zoowel de To Wana als de To Loinang door verschillende vermenging zijn opgebouwd, hetzelfde moet zijn. Dit is dan een volk met sterk Melanesische trekken. 


\section{Het Huldebetoon aan den Heer.}

Doordat de Baloa-menschen door hun geringe vermenging met de vreemdelingen hun democratische samenleving bleven handhaven, en zij geen opperhoofden hadden, had het jaarlijks opbrengen van de schatting met niet veel plechtigheid plaats. Volgens de mededeelingen heeft men de schatting slechts éénmaal naar de monding van de Loboe gebracht; na dien tijd ging men er mee over de bergen naar Tangkian. Een reden voor deze verandering wist men niet op te geven; maar een verhaal als bij de Lingketeng-clan, waarin wordt verteld van de ontmoeting van twee Hoofden in het gebergte, terwijl men aan het jagen was, kent de Baloa-clan niet. Vermoedelijk heeft deze verandering plaats gehad in navolging van de Lingketengmenschen, en onder invloed van Banggai. Dat aan het Baloa-volk een anderen ,heer" is aangewezen dan aan de Lingketeng-groep, zal wel een gevolg zijn geweest van de vijandschap, die er voortdurend tusschen die twee clans heeft geheerscht. Tangkian en Kintom liggen 7 K.M. van elkaar verwijderd, en de bevolking van leide plaatsen is nauw aan elkaar verwant. De weinige dorpen van Loinangs boven Kintom, Tangkian en Batoei zijn volgens de menschen een gevolg van het verkeer met de woonplaatsen van de beide heeren des lands.

Volgens de mededeeling van oude lieden zal de hoeveelheid rijst, die de Baloa-clan jaarlijks opbracht, ongeveer twee pikoel hebben bedragen. Verder bracht men den heer hoenders. Dezen tocht ondernam men elk jaar na afloop van den rijstoogst. Als tegengeschenk kregen de menschen aarden kookpotten en lappen katoen.

De heeren of Sengadji van Kinton en Tangkian droegen den titel van bosanjo, dat vermoedelijk ,de groote" beteekent. De opperhoofden van de clans der To Wana hadden eveneens denzelfden titel. Hij zal wel van Banggai afkomstig zijn. Behalve in beide genoemde plaatsen waren nog bo s a $j$ o te Batoei, Mendono, Nambo, Lantio en Loeok (Loewoek), maar met deze „heeren” hadden de Loinangs niets uit te staan.

Voordat ik een en ander mededeel over het ceremonieel, waarmee de schatting door de Lingketeng-clan naar Kintom werd gebracht, moet ik eerst iets zeggen van de waardigheidsbekleeders in het Lingketeng-gebied. We weten reeds, dat het Opperhoofd, de daka'njo, in Lingketeng woonde, en dat over het distrikt Pinapoean de voornaamste tonggol bevel voerde. We hebben gezien, dat er nog meer 
tonggol waren, maar deze hadden minder aanzien dan die van Pinapoean. Dat deze zeer groot is, wordt verklaard uit de omstandigheid, dat toen de heer (bosanjo) van Kintom voor het eerst in dit land kwam, hij bij den eersten tonggol van Pinapoean, Tibahakon genaamd, inkeerde. Maar hier zullen oorzaak en gevolg wel met elkaar verward zijn. Uit het bovenmedegedeelde blijkt duidelijk, dat de tonggol van Pinapoean nauw verwant zijn aan het geslacht van den ¿aka'njo. Alle tonggol hadden tot hunne beschikking: een pabisala (de pabisara ,woordvoerder" van de Boegineesche hoven), en de mian kopian, ,de vredestichter". Die twee hielpen den tonggol zaken onderzoeken en beslechten. Verder had de tonggol nog een melinoe, een soort van oppasser of bode, die overal heen gezonden werd om boodschappen of bevelen over te brengen, en die de menschen moest oproepen. „De tonggol riep den melinoe met den mond”, vertelde de tegenwoordige hoofdman van Pinapoean, ,want we hadden toen nog geen gongs".

De daka'njo van Lingketeng en de tonggol van Pinapoean genoten van hun onderdanen dezelfde diensten. Dezen kwamen onder leiding van hun eigen dorpshoofden helpen bij het akkerwerk van hun opperhoofd. Wanneer een van die twee een huis noodig had, bewerkten de menschen het hout er voor, en brachten de dakbedekking, de planken enz. bijeen. Deze dorpshoofden droegen den titel van langka-langkai. Langkai heeft weer de beteekenis van ,groot” (in 't Morisch is langkai nog het gewone woord voor ,groot"); de reduplicatie wil dus zeggen: ,de eenigszins groote”, de op één na groote. Aan den daka'njo bracht elk huisgezin van het Lingketeng-distrikt na afloop. van den oogst een mandje (baki) met rijst, een bamboe vol palmwijn, en een hoen, en daarna zorgde men, dat de schatting voor Kintom bijeenkwam. Van den jachtbuit kreeg de daka'njo niets, maar wanneer men een gemsbuffel slachtte, gaf men hem daarvan vooraf kennis, en schonk hem 4 brokken van het vleesch, veelal stukken uit de halsstreek.

De schatting aan den heer te Kintom bestond in de eerste plaats uit gepelde rijst. Deze schatting heette hoehoe (Poso roeroe) of bagi toempoe "het deel van den eigenaar" (van het land, of misschien: van de rijst). Iedere nederzetting of Langka-langkai-schap bracht een batadi rijst op. Een batadi is een kokervormige mand, van de bladscheede van den sagopalm gemaakt. Ook de daka'njo, en iedere tonggol zorgde voor zoo'n ba adi met rijst, maar de mand van de laatstgenoemden was grooter, bevatte ongeveer 25 kati rijst, en was 
met een deksel afgesloten, wat bij die van de anderen niet het geval was. Zoo'n batadi met deksel heet kinoloban. Die van een langkalangkai was kleiner, bevatte ongeveer 15 kati rijst; zoo'n vat heet bebesokon. $\mathrm{Al}$ deze manden of vaten met rijst werden afgeleverd atan den bosanjo (sengadji) van Kintom; alleen die van den daka'njo werd door menschen van Kintom naar Banggai gebracht.

De langka-langkaischappen van Pinapoean waren: Soeasa, Koepedja, Alawi, Koong, Tonggi ngkalia. In Tonggi ngkalia was de tonggol. De heele streek werd vergeleken met de vingers van de hand, waarvan de middelvinger, die boven de andere uitsteekt de kinoloban, de andere de bebsokon zijn.

Verder bestond de schatting uit stukken (kelong) bijenwas (tahoe) van een span lengte en de dikte van de pols; een tonggol zorgde voor 25 van die stukken, een langka-langkai voor 15 .

Wanneer de afgesproken dag, waarop de schatting zou worden gebracht, was aangebroken, ging de daka'njo met al zijn tonggol, en een menigte mannen op weg. Men was wel 150 man sterk. In het dorp Poesoek, dicht bij Kintom, gekomen, werd rust gehouden om de lieden van Kintom gelegenheid te geven zich op het bezoek voor te bereiden. In Poesoek woonde de kapitan tano; diens plicht was het de huldebrengers naar den heer te geleiden. Als men zich in optocht naar Kintom begaf, liep de daka'njo voorop, dan volgde de kapitan tano; na dezen kwamen de tonggol, en dan volgde een man, die den titel droeg van toema noe daka'njo ,vader van den daka'njo”, zooveel als „oudste”. De Sengadji van Kintom had ook een toema noe bosanjo "vader van den bosanjo". Deze betrekking ging over van vader op zoon. Wanneer de toema overleden was, had er bij de aanstelling van den nieuwen functionaris een groot feest plaats. Bij die gelegenheid gaf de daka'njo hem een nieuw stel kleeren, dat de toema zoolang droeg tot het van zijn lijf viel. Wanneer de daka'njo aîwezig was, verving de toema hem. De daka'njo besliste geen zaak, of de toema moest er bij tegenwoordig zijn. De toema huwde wel eens met een zuster of een dochter van den daka'njo, maar uit het toema-geslacht kon nimmer iemand tot daka'njo worden aangesteld. Vermoedelijk hebben wij in den toema ,,vader" de vertegenwoordiger te zien van een hoofdengeslacht van de oorspronkelijke bevolking, voor wien bij de vermenging met de hooger staande vreemdelingen, dit ambt werd geschapen, dat wel eer, maar geen macht gaf.

Wanneer nu de dakanjo in het huis van den Sengadji (bosanjo) was gekomen, liep hij door naar het slaapvertrek van dit Hoofd. 
Tlaar ging hij aan het voeteneinde van de slaapplaats zitten, en dan kwamen enkele menschen van Kintom hem de voeten wasschen. Wanneer dit was afgeloopen, ging hij den Sengadji (bosanjo) de hand geven. Vervolgens geleidde deze den daka'njo naar de ontvangzaal, en de slaapmat, waarop de laatste bij de voetwassching had gezeten, werd hem achterna gedragen. Als deze mat in de ontvangzaal was uitgespreid, zetten beide Hoofden zich daarop neer, de daka'njo aan de rechterhand van den bosanjo. Dan werd de schatting, bagi toempoe, vóór den Sengadji opgestapeld; alleen het aandeel van den daka'njo werd afzonderlijk naast den stapel gezet. Als alles gereed was, nam de toema noe daka'njo het woord. Hij zeide: „Met eerbied geven wij de bagi toempoe over; alle zeven tonggol zijn hier tegenwoordig”. Dan antwoordde de Sengadji: „Ik geef den zegen aan de 7 tonggol en aan den daka'njo". Hiermede was de eigenlijke plechtigheid afgeloopen. Dit alles gebeurde in den loop van den ochtend. Dan bracht men de bakjes met eten binnen en zette men zich aan den maaltijd. Tegen den avond had weer een maaltijd plaats, en daarna bracht men den nacht verder door met mosakalelez'oe, montontila, montende, alle dansen, waarop ik beneden terugkom.

Wanneer de huldebrengers naar hun land teruggingen, schonk de Sengadji aan den daka'njo en zijne tonggol stukken katoen van de soorten, die den naam dragen van kasambang en boekoe; ook gaf hij fraaie broekbanden, popoehoes; verder een aantal motombing. Deze motombing zijn ook onder de Moriërs en de Oost-Toradja's lekend; onder de laatsten dragen ze den naam van kolokompa. Het zijn kleine saronkjes van circa 3 à 4 d.M. lengte en breedte, waarvan de draden (katoen) ver uit elkaar liggen, zoodat ze doen denken aan nethemden die om het bovenlijf gedragen worden. Ze zijn ongeschikt voor eenig gebruik en toch vertegenwoordigden ze in den ouden tijd een vrij groote waarde, onder de Poso-Toradja's nog grooter dan onder de Loinangs. Bij de eersten wordt in sommige streken tot op den huidigen dag zulk een motombing-weefsel bij den bruidsschat gevoegd. De denkbeeldige waarde, die de Loinangs aan dit weefsel hechtten, zal uit het vervolg van deze mededeelingen blijken. Vanwaar men de motombing gekregen heeft, weet men niet; men onderstelt dat ze van Kintom afkomstig zijn. Vele boeten werden met deze motombing of tombing betaald; had men er geen, dan betaalde een ander, maar dan werd men pandeling bij dien persoon. Voor 1 tombing betaalde men 10 soepa of maten gepelde rijst. Zoo'n 
soepa (Mal. tjoepa) was een stuk bamboe van bepaalde lengte. Een blok ongebleekt katoen (balasoe) gold voor 15 motombing. Dit zelfde aantal kreeg men voor een stoel sagoboomen (sampoeoen ladang).

Wanneer het gezelschap huldebetooners terugkeerde, makkte het halt op een plek in het gebergte, die Kadilan heet, vanwaar men op den Lingketeng-heuvelrug neerziet. Daar werd dan een donderbus afgeschoten, zoodat allen het in Lingketeng hoorden. Later deed men dit op een plek, die dichter bij het dorp gelegen is, en die den naam kreeg van Lontoeban ,waar de knal afgegeven wordt, of plaats heeft". Was bekend geworden, dat de reizigers teruggekeerd waren, dan werd in elk dorp, waar een tonggol woonde, een groote maaltijd bereid, waarbij voor elken dẹelnemer aan den tocht een hoen werd geslacht en een ei werd gekookt.

\section{De Aanstelling van een Daka'njo.}

Voordat het gezelschap huldebetoogers van Kintom heenging, zei de Sengadji (bosanjo) nog: ,Mocht de daka’njo komen te sterven, geef mij daarvan dan dadelijk bericht". Men geloofde vast, dat als men niet zoo deed, de rijst niet zou gelukken, en een besmettelijke ziekte het volk zou komen teisteren. Het bericht van het overlijden van den daka'njo werd door Banggai doorgegeven naar Ternate, en de Sultan van dit rijk zond dan een nieuw baadje, een soort van hadji-jas; ook zond hij een soort hoofdbedekking, dat den naam draagt van kokoa. Deze kleedingstukken, welke aan den laatsten daka'njo hadden toebehoord, worden nog zuinig bewaard; en ze spelen nog steeds een rol bij verschillende godsdienstige handelingen, waarover beneden meer.

Wanneer de daka'njo overleden was, kwamen alle clangenooten op om den rouw over hem aan te nemen, kabaloe. Aan elken tonggol werd kennis gegeven van het overlijden van den daka'njo door hem een stuk wit katoen van anderhalven vadem te zenden. Dezen lap geeft de tonggol aan den krijgsaanvoerder, talenga, en deze trekt er met een bende op uit om een of meer koppen te gaan snellen. Is hij om de eene of andere reden niet in staat om menschen voor dit doel uit te zenden (bv. door ontstentenis van een krijgsaanvoerder), dan is de tonggol verplicht den lap wit katoen zelf te dragen. Als de tonggol ter begrafenis kwam, bracht hij een blok ongebleekt katoen (balasoe) mee. $\mathrm{Na}$ de begrafenis keerden allen naar huis terug, en dan kwam men na $2 \times 7$ dagen terug voor het dooden- 
feest. Iedere tonggol droeg daarvoor 4 binoentoeng of kokers vleesch en een mand rijst bij; de overige bevolking zorgde voor rijst, hoenders en bamboes met gerookt gemsbuffelvleesch.

Bij het doodenfeest werd ook de nieuwe daka'njo aangesteld. Van te voren was reeds uitgemaakt wie den overledene zou opvolgen. Gedurende de periode van $2 \times 7$ dagen na het overlijden nam de toema noe dakinjo het ambt waar. (Op zijn beurt nam bij het overlijden van den toema de daka'njo diens ambt waar gedurende de genoemde periode na het overlijden). Gewoonlijk was ook de Sengadji (bosanjo) van Kintom bij het doodenfeest aanwezig. Deze vroeg dan eerst aan den toema, wien men als daka'njo wenschte. Wanneer deze den naam had genoemd, deed de Sengadji dezelfde vraag aan den tonggol poesaka „erftonggol”. Deze man moest steeds te Mongolos wonen, een plek op den Lingketeng-heuvelrug tusschen de dorpen Indang en Baningin (mongolos beteekent een ingezakte plek tusschen de bergen). Had ook de tonggol poesaka geantwoord, dan werd de gekozene door den toema met de reeds genoemde jas en hoofdbedekking bekleed. waarna hij zich vóór den Sengadji neerzette. Deze legde hem een hakmes op het hoofd en sprak: Akoe mamposoehang $i$ Anoe timbali daka'njo. Montebeni po'oehan natimbongon; po'oehan na mokini; po'oehan na mabongon; po'orhan na maboetak. Be'i oemoeoemoen, be'i penta-pentan, isa, doea, toloe, opat, lima, anom, papitoe. „Ik plaats (stel aan) NN als daka'njo. Dat zijn leven niet kort zij, dat hij niet de geelzucht krijge, dat hij niet doof worde, dat hij niet blind worde. Geef hem een lang leven; geef hem gevatheid (verstand). Een, twee, drie, vier, vijf, zes, zeven". Daarna werden hem een nieuw kleed en een nieuwe hoofdbedekking gegeven. Een kanonnetje, lela, werd afgeschoten, en een groot feest werd gevierd, waarop krijgsdansen (oemapos) werden uitgevoerd, en allerlei reidansen werden gehouden.

Wanneer het huis van den daka'njo moest worden gemaakt of hersteld, kwamen alle tonggol met hunne mannen daaraan helpen, en ze zorgden voor het benoodigde materiaal. Bij het ontginnen van den grond voor een akker, bij het planten en wieden van de rijst kwam men hem helpen, maar voor het binnenhalen van den oogst moest hij zelf zorgen. Alle lieden die hunne aangelegenheden met hem kwamen bespreken, kregen van hem te eten. Leden van de tonggol-families huwden vaak met bloedverwanten van den daka'njo.

Men vertelde mij, dat er oorspronkelijk geen slaven waren geweest, maar door schulden en het opleggen van boeten, die men niet kon D1. 86. 
betalen, vervielen velen in pandelingschap. Deze schuldslaven werden vaak door den daka'njo en de tonggol verkocht; voornamelijk naar de Togian-eilanden, vanwaar men naar den vasten wal kwam om slaven te koopen. Hoogstwaarschijnlijk is dit echter een kwaad geweest, dat zich pas enkele tientallen jaren vóór de komst van het Gouvernement heeft ontwikkeld, toen zich reeds vreemdelingen (Boegineezen) in de Tomini-bocht hadden gevestigd.

Meermalen vluchtten schuldenaars naar den Sengadji van Kintom. Deze betaalde dan hun schuld en dan bleef de schuldenaar met zijn gezin bij dit Hoofd. Aan dit gezin werd een plek aangewezen, waar het kon wonen en akkers aanleggen. Dit waren „menschen van den bosanjo". Op deze wijze moet het aantal zijner onderhoorigen snel zijn toegenomen. Alle krijgsgevangenen moesten aan den bosanjo worden afgegeven. Menschen koopen of verkoopen deed hij nimmer, en meer dan eens heeft men mij gezegd, dat de bosanjo niets afwist van het verkoopen van menschen naar de Togian-eilanden, want anders zou hij dit zeker verboden hebben.

Een pandeling kon zich vrij maken door zijn schuld te betalen, maar meestal kwam niets hiervan. Hij werd als een slaaf behandeld, en daarom had hij weinig gelegenheid eigendommen te verzamelen. De som die hij aan zijn meester moest betalen om vrij te komen, was steeds hooger dan zijn oorspronkelijke schuld bedroeg. Het aflossen van een schuld om vrij te komen heet batolos.

Wanneer een aanzienlijk persoon in schuld was geraakt en hij kon niet betalen, durfde men hem niet te gijzelen, maar dan trachtte men zich op een slinksche wijze meester te maken van een zijner kinderen. Wanneer de vader zag dat men zijn kind opving, kwam het wel tot een gevecht, maar als hij van het geval vernam, wanneer het kind reeds in de macht van den ander was, dan berustte hij er in onder het gevoel van zijn schuld; hij trachtte dan zoo spoedig mogelijk zijn schuld af te doen, ten einde zijn kind terug te krijgen.

$$
\text { Rechtspraak. }
$$

Alle geschillen werden door den tonggol beslist. Kon deze het niet af, dan ging men er mee naar den daka'njo. Deze was de eenige die het recht had iemand in het blok te sluiten: de enkels werden dan gelegd in halfcirkelvormige uithollingen in den kant van een dikke plank. Een dergelijke plank werd er bovenop geplaatst, zoodat de enkel in een gat besloten was, waaruit de yoet niet kon worden weggetrokken. Zoo'n blok heet panga'an. Soms werden dieven op 
deze wijze vastgehouden, voordat hun zaak was berecht; maar het misdrijf waarvoor men in 't bizonder in het blok werd gesloten, was, als iemand uit boosheid over het verloop van een rechtsgeding vóór den afloop der zitting wegliep; dit heette molengkati. Daar men dit vergrijp tegen de adat altijd en soms uitsluitend noemde, wanneer ik vroeg welke overtredingen met het sluiten in het blok werden gestraft, schijnt het wegloopen van de zitting nogal veel voorgekomen te zijn. Voor dit misdrijf bleef men drie dagen in het blok gesloten.

Nimmer werd een zaak voor den Sengadji van Kintom gebracht. Alleen als men besloten had om iemand te dooden, hetzij omdat hij zich met zwarte kunst zou bezighouden, hetzij om bedreven bloedschande, of omdat men zich om zijn onbehoorlijk gedrag van hem wilde ontdoen, moest men hiervoor eerst toestemming van den Sengadji van Kintom hebben. Deze werd altijd geredelijk gegeven, onder voorwaarde, dat de kinderen van den veroordeelde aan hem moesten worden gebracht, zoodat ook op deze wijze het aantal van „zijne menschen" toenam.

Een menschenleven had in den ouden tijd blijkbaar niet veel waarde. Ik kreeg verhalen te hooren, hoe men elkaar om kleinigheden te lijf ging. Een van die gevallen deel ik hier als voorbeeld mede: Een man uit Pinapoean gaat het bosch in om te jagen. Gedurende zijne afwezigheid trekt een oom van hem met diens vier zoons naar het strand; de vrouw van den jager sluit zich bij het gezelschap aan. De man komt terug en vindt zijn huis leeg. Hij hoort van de menschen dat zijn vrouw met zijn oom en neven mee getrokken is naar het strand. De man denkt dat ze dit met booze oogmerken heeft gedaan; in zijn boosheid gaat hij naar den akker van zijn oom en hakt daar het gewas tegen den grond; ook de sagoboomen van zijn oom vernielt hij. - Na enkele dagen komt het reisgezelschap terug, en verneemt wat er is voorgevallen. De oom en zijn zoons wapenen zich, en zoeken den man op, die hun velden heeft verwoest. Deze staat alleen door zijn zwager bijgestaan tegenover de vijf. In het gevecht dat volgt, worden beiden gedood; van de aanvallers wordt één gedood, en een ander werd met een speer door de wang gestoken. Na afloop van den strijd wordt de zaak voor den tonggol gebracht. Deze beslist dat aan beide kanten evenveel slachtoffers moeten vallen, en daarom wordt de vrouw, die aanleiding gegeven had tot al de ellende, aan menschen van het eiland Walea verkocht. 
Wanneer men iemand zonder opzet verwond had, werd tampong of pontampong (,instopsel, oplegsel”) geëischt. Het bedrag daarvan was zeer verschillend, en hing van vele omstandigheden af : van de verhouding waarin de twee personen tot elkaar stonden, en van den aard van de eischende partij. Meestal varieerde deze boete tusschen 1 en 4 blokken ongebleekt katoen (balasoe). Wanneer te veel gevraagd werd, moest de mian kopian of ,vredestichter” beslissen.

De grootte van de boete bij doodslag hing van dezelfde omstandigheden af. Waren de partijen elkaar welgezind, dan zorgde de doodslager voor het doodskleed van den verslagene, en gaf hij een bijdrage tot het doodenmaal. Of men gaf 10 à 12 blokken katoen, dit is ongeveer de helft van den prijs, dien men voor een slaaf betaalde. Of de doodslager ving bij de andere clan een kind op, en gaf dit aan de familie van den verslagene, met nog vier blokken ongebleekt katoen er bij. Maar in de Lingketeng-clan schijnt het meermalen te zijn voorgekomen, dat er naar aanleiding van doodslag een gevecht ontstond tusschen de beide families, waarbij dooden vielen, en kinderen tot slaven werden gemaakt. Bij de Baloa-lieden kwamen zulke dingen volgens de getuigenissen niet voor.

Wanneer men de oorzaak was, dat eens anders huis afbrandde, gold als regel, dat die persoon alle schade vergoedde. Wanneer iemand bijvoorbeeld het gevelde hout op zijn akker ging verbranden, en hij had allen, wier woningen in de nabijheid van zijn veld stonden, gewaarschuwd, waarbij hij tevens de hulp dier lieden had ingeroepen om over het vuur te waken, dan ging ,de eigenaar van het vuur" vrij uit als er soms een huis in de asch werd gelegd, ja al verbrandde de heele kampong.

Had iemand iets van een ander weggenomen, dan gold als regel, dat hij de dubbele waarde van het gestolene vergoedde. Had men bijvoorbeeld een hakmes weggenomen, en kon men het teruggeven, dan moest de dief er nog een hakmes als boete bij doen. De boete werd bij de Lingketeng-lieden vaak voldaan in tombing of motombing, de reeds beschreven lapjes van een soort zakkegoed. Voor een voorwerp van niet al te groote waarde bedroeg de boete vijf van die lapjes; het gestolene moest daarbij steeds worden uitgeleverd. Was men hiertoe niet meer in staat, dan werd de boete veel zwaarder. Het wegnemen van kleinere dingen, b.v. het stelen van een hoen, werd met 2 motombing beboet; voor het gestolen hoen werd een ander in de plats gegeven.

Veel zwaarder werd het stelen van rijst gestraft. Wanneer iemand 
betrapt werd op pogingen om de schuur te beklimmen of te forceeren, (lan moest hij 8 motombing betalen. Nam iemand rijst van den akker weg, dan had hij 15 aarden borden te betalen. Had men rijst uit de schuur weggenomen, dan werden hem 30 leang (realen) als boete opgelegd, al had hij slechts 1 bos weggedragen. De boete kon zelfs oploopen tot 25 balasoe. Gewoonlijk was de dief niet in staat zoo'n hooge boete te betalen. De daka'njo deed dit dan voor hem, en de schuldige werd pandeling. Gewoonlijk kwam eenvijfde van de opgelegde boete aan den daka'njo als belooning voor zijne moeite. Dit loon heet oedjoe laa; hij deelde dit met den toema en den tonggol, die mede hadden gewerkt op de rechtszitting.

Kwaadspreken of lasteren heet mohait. Deed men dit van een tonggol, dan moest men 4 motombing geven als zoen; gold de lastering een gewoon mensch, dan waren 4 lapjes voldoende.

Het kwam natuurlijk vaak voor, dat men ter terechtzitting ontkende schuldig te zijn aan het hem ten laste gelegde. Men was er dan ook spoedig bij om met krachtige bewoordingen zijn onschuld te betuigen, en allerlei onheil over zich af te roepen, ingeval men onwaarheid mocht hebben gesproken. Dergelijke zelfvervloekingen waren voor de beslissing van eenige zaak van geen beteekenis.

Om te weten te komen wie gestolen had, werd gewicheld, metahi, zooals men ook doet wanneer men wil weten of een zieke zal herstellen of niet. (Ik kom beneden op dit wichelen terug). Was op deze wijze een persoon aangewezen, dan werd hij beschuldigd (mompotoka). Dat het orakel hem als den dief had aangewezen, gold niet onomstootelijk als bewijs, dat hij werkelijk schuldig was. Die persoon ontkende dan ook gewoonlijk heftig alle schuld. Wanneer er niet voldoende bewijzen voor de schuld waren bij te brengen, zat er niet anders op, dan de zaak door een godsoordeel te doen beslissen.

Men kent nog een spiritistisch gekleurd middel om den dief van een of ander vermist voorwerp uit te vinden. Dit noemt ment mongkokoesoe, maar dit kent meni alleen bij de Lingketeng-lieden. De leider van het experiment neemt dan een gewone rijstwan, waaraan hij een touw vastbindt, waarvan hij het andere uiteinde in de hand houdt. De wan ligt plat op den vloer van het huis van den leider. $\mathrm{Nu}$ neemt hij wat ongepelde rijstkorrels en legt die in het vuur; terwijl ze verbranden, spreekt hij ze toe, maar men kon mij niet vertellen wat de man zegt. $\mathrm{Na}$ een poos begint de wan heftig te bewegen en schokt weg, voorțurend op den vloẹ slaande. Met 
rukken beweegt ze zich voort en trekt het medium, dat de lijn vasthoudt, met zich mee. Zoo gaat het langs den weg naar het huis van den dief, die soms in een ander dorp woont. Is de dief gevonden, dan slaat de wan heftig tegen hem aan, soms tegen zijn hoofd. Het medium laat zich bij zijn werk altijd van een aantal gewapende mannen vergezellen, omdat het wel eens op een vechtpartij kan uitloopen, wanneer de dief op deze wijze is aangewezen. Het was een gezelschap van drie mannen, dat mij dit experiment mededeelde, en alle drie beweerden het met eigen oogen gezien te hebben. - Soms blijft men in huis: dan worden een aantal kokosdoppen om de wan heen gelegd op den vloer, en aan elken dop geeft men den naam van een persoon, die mogelijkerwijs het vermiste voorwerp zou hebben kunnen wegnemen. In dit geval sleept de wan het medium niet mede naar buiten, maar geeft een klap op den dop, die den naam van den dief draagt.

Het godsoordeel, dat het meest wordt toegepast om uit te maken of iemand schuldig is of niet, is het duiken, makakiop. Om de verdenking, dat iemand aan zwarte kunst doet tot zekerheid te maken, wordt een ander godsoordeel aangewend, waarover we beneden zullen spreken. Wanneer een zaak zal worden uitgemaakt door de duikproef, komen beide partijen aan den oever van een rivier te zamen. Het Hoofd, dat de leiding van de zaak heeft, roept de balakat (Mal. berkat, hier in den zin van bovennatuurlijke macht) van Banggai aan. Aan deze balakat wordt gevraagd om den aangeklaagde vrij te spreken of schuldig te verklaren. Na afloop van deze aanroeping, herhaalt de eene partij hare beschuldiging, waarna de beschuldigde zijne schuld plechtig ontkent. Beiden roepen de gerechtigheid aan om hunne woorden waar te maken.

Iedere partij heeft een man angewezen, die voor haar zal duiken. Beiden staan in het water en houden een stok vast, die in de bedding der rivier is geplant. Op een teeken van het Hoofd verdwijnen beiden onder water, en in spanning wachten de omstanders af, wie van de twee het eerst boven zal komen. Komt de beschuldigde het eerst te voorschijn, dan is hiermede bewezen, dat hij schuldig is, of ongelijk heeft. Werd het godsoordeel gehouden om een diefstalzaak, dan moest de schuldige een zware boete betalen, soms tot 50 blokken ongebleekt katoen toe, waarvan dan 20 blokken voor den aanklager (bestolene), terwijl 30 blokken werden verdeeld onder de aanwezige Hoofden, die hun medewerking bij de rechtzitting hadden verleend. 
Kwam de duiker van den beschuldiger het eerst boven, dan bleek hieruit dat de aanklacht valsch was, en had de aanklager een zware boete te betalen aan den verdachte. Deze boete varieerde tusschen 8 en 20 blokken ongebleekt katoen. Deze boete heet kinaha'i.

Naast het duiken kent men nog een ander godsoordeel, dat momamas ,warm maken” heet. Dit wordt op twee wijzen toegepast: een koperen duit wordt in kokend water gelegd, en dit geldstuk moet de beschuldigde er met de hand uithalen. Wanneer de hand daarna. geen brandwonden vertoont, heeft hij hiermee bewezen onschuldig te zijn. - Of men maakt een stuk ijzer gloeiend (montoenoe lambing), en daarmede wordt over de palm van de hand gestreken. Verdraagt de beschuldigde dit zonder van pijn de hand toe te knijpen, dan is hij onschuldig. Dit momamas wordt o.m. toegepast, wanneer een man tegenover een vrouw, die zwanger is, volhoudt, dat hij niet de vader van het kind is. Het momamas werd ook toegepast om uit te maken, of iemand die beschuldigd werd aan zwarte kunst te doen, werkelijk een heks of toovenaar was of niet.

\section{$\mathrm{H}$ u is bouw.}

Wanneer men een huis wil gaan opzetten, wordt eerst gewicheld (mantahi, otahi'i, ,er wordt gewicheld”). Dit gebeurt met de span van de hand of met een pinangnoot; beneden komen wij op de eerstgenoemde wichelmethode uitvoeriger terug. Door dit wichelen wordt in het algemeen vastgesteld of men veilig met het bijeenbrengen van het hout voor de woning kan beginnen. Dit neemt echter niet weg, dat men toch bij den aanvang van dit werk op allerlei vogelgeluiden heeft te letten. Hoort men een ongunstig geluid, dan moet men dadelijk ophourlen. Enkele overigens goede houtsoorten mogen niet voor den bouw van een huis gebruikt worden, omdat de naam er van ongunstig is, zooals kaoe goein en kaoe sala; de eigenaar van de woning zou spoedig sterven, als hij van dit hout gebruik gemaakt had. Voor het maken van een grafhut wordt dit hout echter bij voorkeur gebruikt. Wanneer een boom die geveld wordt, in zijn val gestuit wordt door een anderen boom; of wanneer de stam bij het vallen splijt, kan men het hout van dien boom toch gebruiken. Maar wanneer de omgehouwen boom op den grond valt, en het ondereinde blijft op den stronk rusten, dan heet dit toemben, en het hout van dien boom mag niet voor de woning worden gebruikt, omdat anders de eigenaar er van zou sterven. 
Wanneer het benoodigde hout bijeengebracht is, wordt de plek schoongemaakt, waarop de woning zal verrijzen. Op die plek wordt tegen het vallen van den avond een wit aarden kom neergezet, boordevol met water. Een ter zake kundige blaast er op en spreekt het water toe, waarbij hij het verzoekt om aan de bouwers te openbaren, of de plek geschikt is om daar een huis te zetten. Of anders uitgedrukt: Of de aardgeesten het goed vinden, dat de menschen daar bouwen. $\mathrm{Na}$ deze toespraak dekt de kundige de kom toe met een lap ongebleekt katoen. De kom wordt geplaatst op de plek waar men van plan is de hoofdpaal, oesoi, te planten. Aan den oostkant van de kom legt men vier stuks sirih en vier pinangnoten neer. Den volgenden morgen gaat men naar de kom kijken; blijkt dat er geen water uit de kom is gestort, of op andere wijze de hoeveelheid vocht geslonken is, dan is dit een gunstig teeken; men is dan overtuigd, dat men op deze plek gezond zal blijven. Allen die in het huis zullen wonen, nemen dan een slok van het water uit de kom. Blijkt de hoeveelheid water den volgenden morgen geslonken te zijn, dan zoekt men een andere bouwplaats.

Heeft het orakel gunstig voorspeld, dan maakt men dienzelfden dag eten gereed, en den daarop volgenden dag worden de gaten voor de palen gegraven, beginnende met het gat, dat voor den midden- of hoofdpaal, oesoi, is bestemd. Dan wordt een bakje (soehoe) gemaakt van pisang- of Dracaena-blad; daarin stort men wat kokosolie, en legt er een oud Hollandsch dubbeltje in. Dit bakje wordt op den bodem van het gat waarin de hoofdpaal komt te staan, gezet. Vervolgens wordt die paal met water begoten, eens van het onder- naar het boveneinde, en eenmaal in omgekeerde richting. Dan moeten allen, die aan den bouw van het huis medehelpen den paal vasthouden; aan het benedeneind staat de huisvrouw, op haar volgt haar echtgenoot, dan het Hoofd (tonggol), verder een oude man, en dan de overige leden. De leider van het werk spreekt: Momboelakon oesoi, po'oehanna mombindak, po'oehanna toboeto, po'ochanna motaoe, po'ochanna moohop, po'oehanna talomba, po'oehanna motojo, po'ochanna otandoi; mokaoemoenakon, nokabosoeakon nokakazwasaakon nokapentanakon, isa, doea, toloe opat. ,(Wij) richten nu den hoofdpaal overeind; dat wij er niet plotseling door mogen sterven; dat wij er niet ziekelijk van mogen worden; dat wij er niet door naar beneden moeten gaan (d.w.z. zoodanig beboet worden, dat men genoodzaakt is al zijn have naar beneden te brengen om de boete te kunnen voldoen); dat wij geen honger mogen lijden; dat ons huis niet afgebroken (ver- 
woest) worde; dat (ons huis) niet verbrande; dat er niet geweend worde (d.w.z. dat er niets in moge gebeuren, waarover moet worden geweend); opdat wij een lang leven mogen hebben; opdat we (altijd) verzadigd mogen wezen; opdat wij rijk mogen worden; opdat wij gevat (slim) mogen zijn ; 1, 2, 3, 4". Bij 4 heffen allen een grommend geluid (motaligaga) aan, waarmee tevens het rythme wordt aangegeven, waardoor men met vereende krachten den paal oplicht en met den voet in het gat laat glijden.

Zoodra de hoofdpaal in den grond is gezet, gaat men dadelijk door met het planten van de overige palen, en brengt men alle onderdeelen aan. Alleen op dezen eenen dag wordt men door alle kamponggenooten geholpen, zoodat men moet zorgen dat het geraamte van de woning gereed komt. Voor deze gelegenheid wordt een maaltijd aangericht als belooning voor de werkers. Verder werkt de eigenaar van de woning met zijne naaste verwanten het huis af. In den ouden tijd werden voor de dwarsliggers (ila), waarop de eigenlijke vloer komt te liggen gaten in de zijbalken gebeiteld. Dit heet montepek ila ,,gaten voor) vloerlatten uitbeitelen”. Het was een tijdroovend werk, waaraan allen, die den beitel wisten te hanteeren, kwamen helpen, zoodat deze arbeid ook in één dag was afgedaan. Ook bij deze gelegenheid werd een overvloedige maaltijd bereid. Tegenwoordig doet men dit niet, omdat men niet meer zooveel werk van zijn woning maakt als vroeger; men beweert daarvoor geen tijd meer te hebben, omdat men telkens voor allerlei dienstverrichtingen door de Hoofden wordt opgeroepen.

De derde maaltijd bij het bouwen van een huis wordt aangericht, wanneer de daksparren worden aangebracht, voor welk werk van 5 tot 10 mannen worden uitgenoodigd. De vierde maaltijd heeft plaats bij het dekken van het dak, en ten slotte de vijfde en grootste maaltijd bij de inwijding van de woning. De nok van het huis werd niet in een bepaalde richting aangebracht. Herhaaldelijk heeft men mij verzekerd, dat men dit liet afhangen van de gesteldheid van den bodem waarop het huis komt te staan; bij het bouwen op een bergrug zal de nok de richting van dien bergrug volgen. Wanneer men nog aan een richting de voorkeur gaf, dan was het die van Zuid naar Noord. $\mathrm{Bij}$ het aanleggen van nieuwe kampongs onder het Gouvernement is niet op de richting van de nok gelet.

Wanneer het huis zoo goed als klaar is, brengt de eigenaar er zelf den haard (poloe) in aan. Dit is als bij alle volken van Celebes een vierkant gat in den vloer, waarin een bodem is aangebracht, die een paar decimeter beneden den vloer van het huis ligt. Dit kistvor- 
mige gat wordt met aarde gevuld, waarop het vuur wordt aangemaakt, zoodat zich dit niet aan het hout van de woning kan meedeelen. Voordat nu de aarde in het gat wordt gestort, wordt de bodem er van met pinangbladeren en repen pisangstam belegd, en hierop worden 4 groote draagmanden vol aarde leeggegooid. Wanneer de aarde wat gelijk gemaakt en aangestampt is, haalt men vuur uit een ander huis, en samen met dit vuur brengt men een bamboekoker met water binnen, die aan den middelpaal (oesoi) wordt vastgebonden. Terwijl men het vuur op den haard neerlegt, begraaft men in de 4 hoeken daarvan een stukje oebi $(k e l a)$; dit heet pampakani tano ,de aarde te eten geven”, en men wil hierdoor voorkomen, dat het vuur door de aarde heen zal dringen tot aan den houten vloer en hierdoor de woning in brand zal steken.

Gedurende het bouwen van de woning heeft men zich niet veel ingelaten met voorteekenen. Alleen wanneer bij het dekken van het huis een omineuze vogel een ongunstig geluid laat hooren, moet dit kwaad worden weggedaan. Dit geschiedt bij de Lingketeng-clan door het piloeloes of poelias, dat ik later zal beschrijven. Dit moet ook gebeuren, wanneer het houtwerk van de woning kraakt terwijl de eigenaar er van bezig is den haard te maken; ook wanneer op het oogenblik, waarop men in huis komt om dit te betrekken, een boom omvalt; ook wanneer men in den eersten nacht, dien men in de nieuwe woning doorbrengt, droomt, dat de wind de dakbedekking oplicht, of dat het erf door water wordt overstroomd.

De trap wordt altijd aangebracht aan de zijde van het huis waar de haard zich bevindt. Ze moet steeds 5 treden hebben, hetzij ze een werkelijke trap of een ladder is, hetzij ze niet meer is dan een boomstam met inkervingen.

Op den dag waarop het vuur in huis wordt gebracht, wordt de woning betrokken. Zoodra het vuur op den haard lustig brandt, snijdt men een haan den hals af, en laat hem dan in huis rondspartelen, zoodat het bloed uit den halsstomp naar alle kanten rondspat. Dit is ook de bedoeling, want door het bloed wordt de woning stevig gemaakt en alle kwade invloeden worden er mee gebannen. Alleen moet men zorgdragen, dat de vogel bij het rondspartelen niet op het voorste gedeelte van de boenan (we zouden zeggen: het portaal) komt, want dan zou de huisheer spoedig sterven. Zoo moet men ook oppassen, dat het spartelende dier niet met de pooten tegen den haardrand schopt, want dan zou de huisvrouw spoedig sterven. Een gunstig teeken is, wanneer de haan liefst herhaalde malen tegen den 
oostelijken wand van het huis trapt. Wanneer het dier eindelijk is uitgebloed, en stil blijft liggen, gaat men na naar welken kant het de pooten heeft uitgestrekt. Is dit naar het Oosten, dan mag men op veel zegen en voorspoed rekenen.

Behalve de haan met wiens bloed het houtwerk is bespat, worden nog meer hoenders geslacht, waarvan het vleesch door de huisvrouw en hare helpsters wordt klaargemaakt. Degeen die den middelpaal (oesoi) bij het oprichten heeft toegesproken, krijgt twee kippepooten; voor den huisheer worden vier kippepooten klaargemaakt.

Op den avond van dezen dag heeft nog een bizondere plechtigheid plaats: de huisvrouw, de huisheer, de tonggol, en de oude man, die bij het oprichten van de hoofdpaal aan het benedeneinde er van hebben gestaan, scharen zich nu om den paal in huis. De vrouw steekt een harsfakkel (soeloe) aan, reikt deze aan haar man toe; deze geeft haar aan het Hoofd, en deze weer aan den ouden man. De laatste reikt de fakkel weer aan de vrouw toe, die het rondgeven voortzet, totdat de fakkel viermaal om den paal heen is geweest. Dit heet mampalialiana'i. Terwijl men dit doet, spreekt een der vier lieden, gewoonlijk de oude man, de bezwering uit (mohondazvit), waarbij dezelfde woorden gebruikt worden als bij het oprichten van den paal.

Aan de beide uiteinden van den nokbalk en in het midden er van worden twee kokosnoten opgehangen, een in kolobias-blad gewikkeld pakje gepelde rijst en wat sirih-pinang. Deze dingen worden later weggehaald door gasten, die in deze woning verblijven. Priesters komen bij deze gelegenheid niet te pas.

Nadat men de woning betrokken heeft, wacht men vier dagen, waarin niets bizonders gebeurt; gedurende dien tijd mag niets uit de woning worden weggegeven. $\mathrm{Na}$ afloop van die 4 dagen wordt een maaltijd aangericht voor allen, die tot de instandkoming van de woning hebben medegewerkt. Dit feestje draagt den naam van kasompolannjo ,"het teneindebrengen”, het slot van alles.

$\mathrm{Bij}$ het bouwen van huizen wordt tegenwoordig reeds veel het model gevolgd, dat in de Minahassa algemeen is; men ziet dit vooral bij de Lingketeng-clan. Van de oorspronkelijke inrichting van een Loinangsche woning geeft bijgaande plattegrond een voorstelling. ${ }^{\mathbf{}}$ )

Zoo'n oude woning zit gewoonlijk stevig in elkaar. Het huis bestaat eigenlijk uit één groote ruimte, die vierkant zou zijn, wanneer de

1) Het uiterlijk voorkomen der oorspronkelijke huizen is goed te zien op enkele platen in Kaudern's I Celebes obygder II, vooral op de platen 124 en 126. 
vloer niet bij een der hoeken inschoof op de plek waar de trap is aangebracht, die hierdoor onder het dak komt te staan. Deze ruimte is geheel omringd door een anderhalven meter hoogen wand, die in de meeste gevallen van planken is gemaakt. De vloer zelf is van bamboe latten. Op de plaats waar de trap staat, is een deur in den wand aangebracht. Van die plek af loopen twee banen, die een weinig boven den vloer van het huis verheven zijn, maar die niet van de overige ruimte zijn afgescheiden door een wand. De baan langs de lengtezijde der woning heet boenan, en hierop bevinden zich op het

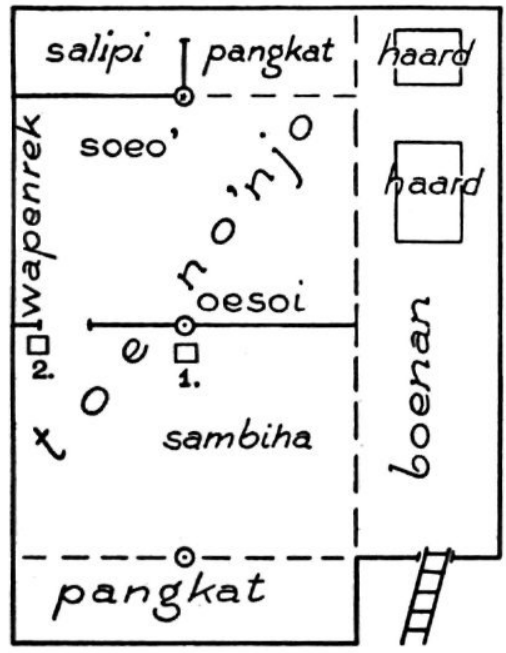

Plattegrond van een Loinangsche woning.

1. De eereplaats voor voorname bezoekers.

2. Zitplaats van den heer des huizes.

achterdeel twee haarden, een grootere voor de gewone bewoners van het huis, en een kleinere voor een oude grootmoeder of ouden grootvader, die een min of meer afgezonderd leven achter in de woning leidt. De vloerbaan langs de breedtezijde heet pangkat, de plaats waar gasten hun verblijf houden, of waar anders de ongehuwde mannen slapen.

Het overige deel van de ruimte draagt den naam van toeno'njo, met den hoofdpaal (oesoi) ongeveer in 't midden er van. In gewone omstandigheden loopt midden door deze ruimte een wand, die de woning in twee deelen scheidt. Het voorste deel zou men ontvangkamer kunnen noemen; dit heet sambiha; daar eet en praat men met gasten en bezoekers. De vaste zitplaats van den heer des huizes is 
bij de deuropening, die beide vertrekken verbindt, zoodat de man steeds het oog kan houden op wat er binnen voorvalt. De eereplaats voor bezoekers is vóór den middenpaal.

Het tweede vertrek is de soeo', het woon- en slaapvertrek van het gezin. Aan den wand tegenovergesteld aan dien waar de haard zich bevindt, ziet men een rek, waar de huisheer wapens en werktuigen en andere dingen bewaart. Achter in huis is meestal nog een klein kamertje, salipi, afgeschoten, waarin de huisheer en de huisvrouw hun bezittingen en kostbaarheden bewaren; ooḱ allerlei huisraad en eetgerei, dat alleen bij bizondere gelegenheden wordt gebruikt.

Op de gedeelten van den vloer waarop men zich te ruste legde (kamale'an ,ligplaats") bracht men dikke planken aan om te voorkomen, dat men in den slaap door den vloer heen met een speer werd doodgestuken (montoehak).

Wanneer het gezin feest viert, wordt de wand tusschen beide vertrekken weggenomen; zoo ook als er een doode is; men kan dan over de heele ruimte van het huis beschikken voor de gasten en bezoekers.

In oudere huizen ziet men soms boven het huis- en slaapvertrek (soeo') een vliering gebouwd, de bangkala. Hier slapen de jonge dochters van het gezin. In nieuwere huizen vindt men geen bangkala, maar slapen de meisjes samen met de ouders in de soeo'. Ik moest er altijd bij hooren vertellen, dat het slapen op deze zoldering geen waarborg was, dat de meisjes geen bezoeken van jongens ontvingen; want de laatsten klommen langs den voorpaal van het huis naar het dak op, en wisten zoo over de dakbalken ongemerkt het verblijf der meisjes te bereiken. In gewone omstandigheden werd het als zeer onbehoorlijk beschouwd, wanneer een bezoeker het tweede vertrek, de soeo', betrad. Men kon hem daarvoor een boete opleggen van 4 notombing. Wanneer een huis afbrandt, wordt op die plek geen nieuwe woning opgetrokken. ${ }^{1}$ )

\section{$\mathrm{Hu}$ is ra a d.}

Huisraad vindt men niet veel in de huizen; het voornaamste bestaat wel uit verschillende soorten van manden. Zoo heeft men de kaliding, een mandje van pandanbladeren met deksel, waarin gestampte rijst

1) Op bl. 338 van zijn boek geeft Kaudern een plattegrond van een Loinangsche woning, die in hoofdzaak met de mijne overeenkomt. Hij laat ook een aantal ornamenten zien, die in het hout van de woningen zijn uitgesneden. Vele oude huizen zijn door nieuwe vervangen, en in de laatste trof ik weinig snijwerk aan. 
en dergelijke worden bewaard. Hierin wordt ook de zaairijst gedaan en naar den akker gebracht, waaruit de kokosdoppen (boean) worden gevuld, die iedere plantster in de hand heeft, en waaruit zij de korrels neemt om die in de pootgaten te storten. - Bosi zijn manden van sagobladscheede die de gedaante hebben van een afgeknotten kegel; deze worden op den rug gedragen. Een dergelijke mand, maar dan van een deksel voorzien is de batadi; deze wordt gewoonlijk alleen gebruikt voor het bewaren van gepelde rijst. Weer een ander type van dezelfde soort is de basoeng (Poso: baso); deze mand is evenals in Poso de onafscheidelijke metgezel van de vrouw, waarin zij haar brandhout en de produkten van haar tuin naar huis draagt. Zulk een mand in den vorm van een afgeknotten kegel, maar dan vervaardigd van repen bamboe, die door een rotanvlechtsel bij elkaar gehouden worden, heet doson. Soms ontmoet men groepen menschen, elk met zoo'n doson op den rug, gevuld met damarhars. ${ }^{1}$ )

Een patembang of takilon is een klein mandje, dat de oogstenden om het middel hangen, en waarin ze de rijst leggen die geen steel heeft. ${ }^{2}$ )

Een veel door vrouwen gebruikte draagmand is de $b a k i$, een rotanvlechtwerk, dat in den vorm van een afgeknotte pyramide opgebouwd is op een vierkant raampje van hout.

Naast veel emaille werk dat men in de toko's koopt, stammen de koperen schalen met en zonder voet nog uit den ouden tijd. Boeten schijnen er niet mee te zijn betaald, zooals zoo vaak onder de Toradja's roorkwam. Deze koperen schalen, doelang, werden voornamelijk gel,ruikt om daarop bij feestelijke maaltijden het eten op te dragen. Daar men slechts enkele van deze schalen bezit, wordt het eten voor de andere gasten gelegd op langwerpig vierkante rekjes, die gemaakt zijn van de bladsteel (ambaha, Mol. Mal. gaba-gaba) van de sago, die in den vorm wordt gehouden door rotan banden, waarop een pisang, of een tike- of tambeako (Heliconia Bihai)-blad worden gelegd, waarop een paar pakjes rijst en vier van palmblad vervaardigde bakjes voor de toespijs. Dit rekje is nog voorzien van vier pootjes, die in een tweede vierkant van sagobladsteel gestoken zijn. Vaak ziet men

1) Een afbeelding van zulk een rij damarharsdragers geeft Kaudern in I Celebes obygder II, b1. 335. Hierop zijn duidelijk de doson (rechts) en de kazvako (links) te herkennen.

$\left.{ }^{2}\right)$ Tegenover bl. 320 van I Celebes obygder II geeft Kaudern een reproductie van een olieverf schilderij van Alisa, als ze op weg gaat om te oogsten; om haar middel hangt de patembang of takilon; op den rug draagt ze de basoeng, waaruit een kaliding komt kijken, waaroverheen weer een zonnehoed is gelegd. 
die rekjes, die den naam dragen van aga-agalan, op hoopjes aan den buitenkant van het huis hangen.

Een gebruiksvoorwerp, dat de aandacht van alle reizigers onder de Loinangs trekt is een kleine kast of doos, die de mannen aan twee koorden over de schouders hangende bij zich dragen. Dit kistje, tibok geheeten, is circa 25 c.M. lang en 13 à 15 c.M. breed; gesloten is het 1 decimeter hoog. Het is van hout gemaakt, en aan het uiteinde van den bodem is een knop uitgesneden. Dit kistje is in vakken verdeeld, zooals de bijgevoegde figuur laat zien; het geheel wordt

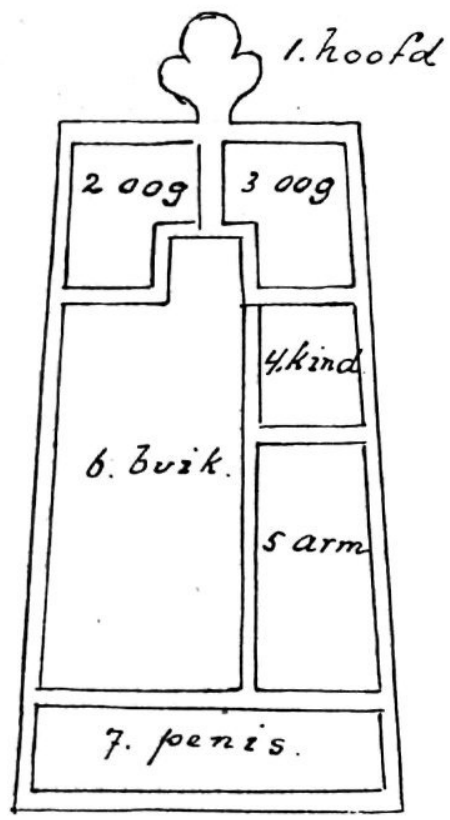

Indeeling van de Loinangsche sirihpinangdoos (tibok), 2/7 der ware grootte.

vergeleken met het menschelijk lichaam: 1 de knop is het hoofd; 2 en 3 zijn de oogen, en het beschot dat die ruimte van elkaar scheidt, is de neus; 4 draagt den naam van het kind, maar bedoeld wordt de baarmoeder; 5 is de arm, 6 de buik en 7 de penis, terwijl de rand onderaan, die dikker is dan op andere plaatsen, de voeten heeten. In 2 wordt tabak bewaard, in 3 kalk, die steeds met de rechterhand daaruit genomen moet worden; in 4 legt men de zwam van den arenboom, die noodig is om vuur aan te maken; in 5 bevinden zich allerlei kruiden, die men onderweg noodig kan hebben als men ver- 
wond raakt of ziek wordt. In 6 is een flinke voorraad sirih en pinang, en in 7 vindt de vuursteen (behese) een plaats. Het deksel is van de bladscheede van den sagopalm gemaakt, en sluit geheel over de doos heen; daarin bewaart men de droge arenbladeren om er sigaret- ten van te draaien en een voorraad tabak. Ook zag ik daarin vaak een gedraaid touw van arenvezels, aan welks uiteinde het in gloed gebrachte stukje zwam wordt gedrukt, waardoor het vuur zich aan de arenvezels mededeelt; met deze lont kan men dan het vuur overbrengen op damarhars, houtspaanders en dergelijke. Daarin bevindt zich ook een els, waarmee men een vlechtsel van rotan kan maken om het handvat van een hakmes en dergelijke. In het deksel wordt een stuk sagobladscheede gedrukt, zoodat de genoemde voorwerpen er niet uit kunnen vallen als men het deksel omkeert. ${ }^{1}$ )

De vrouwen gebruiken de tibok niet, maar zij bedienen zich van de singkolop, dit is een mandje met deksel van pandanblad gevlochten. Enkelen hebben ook een soort van tasch, botetoe, waarin ze de pruim-ingredienten met zich dragen, maar dit voorwerp is van de To Wana overgenomen.

Sirihkauwen heeft men sedert menschengeheugenis gedaan. Dat er een tijd geweest zou zijn, dat men dit niet zou hebben gekend, weet men niet. Wel kan men nog vertellen, dat er in den ouden tijd nog geen pinang was; men maakte toen in stede daarvan gebruik van de vruchten van de hompoe, sohoa en side, wat men uit gebrek aan betel tot op heden doet.

Naast sirihkauwen heeft men het rooken van tabak ook van ouder her gekend. Sedert men tot het Christendom is overgegaan, is de gewoonte van het rooken aanmerkelijk toegenomen, want nu men de tanden niet meer kort, meent men dat het kauwen van sirih niet meer te pas komt.

Aarden potten vindt men op het rek boven den haard staan. Ze werden oorspronkelijk alleen aan de Poko'oehan-rivier gemaakt op de gewone meermalen beschreven manier (zie De Bare'e sprekende Toradja's. II, bl. 335 e.v.). In den ouden tijd kochten de menschen van Pinapoean leem van de lieden van de Poko'oehan, en begroeven die in den grond. Die leem groeide, en thans vindt men veel van die klei in die streek, zoodat men daar ook potten bakt. Zoo vertelt men. Overal uit het binnenland komt men naar de Poko'oehan toe om potten te koopen. Tegenwoordig koopt men ze al naar de grootte

1) Op bl. 327 van I Celebes obygder II geeft Kaudern een afbeelding van de sirihdoos of tibok. 


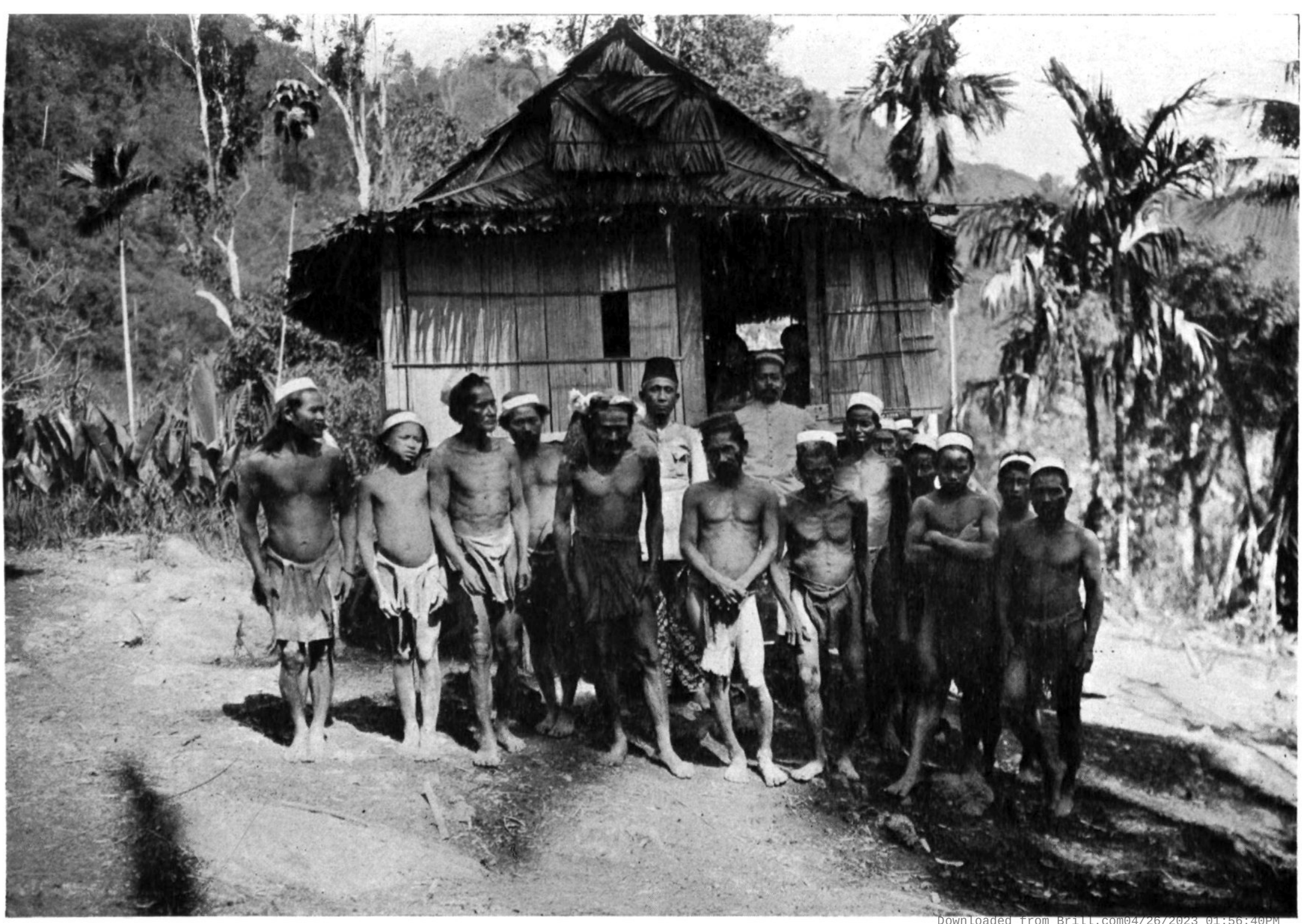

Een groep mannen van Simpang (foto W. E. C. Veen, Ass.-Res.) 
met 2 of 3 koemolan, d.z. pakken damarhars van bepaalde afmeting.

Naast het koken in potten is het bereiden van spijs in bamboe kokers nog algemeen in zwang. De koker wordt daartoe van binnen met jong pisangblad belegd, of de gepelde rijst wordt vooraf in pihaki- of tikala-bladeren (een Amomum-soort) gepakt, en deze pakjes worden in den bamboe koker geschoven, waaraan dan water wordt toegevoegd.

Rijst is het hoofdvoedsel der Loinangs, maar daarnevens eet men nog veel sago, die zoowel uit de Metroxylon als uit de Arenga wordt gewonnen. De wijze waarop dit geschiedt, is geheel en al die welke men overal in Midden Celebes vindt; het merg van den palm wordt zoowel met de hand gekneed in een bak, als met de voeten uitgetrapt in een stevige mand van rotan om de sagodeelen in het telkens daaraan toegevoegde water te doen oplossen, waarna dit van sagomeel verzadigde water in een bak vloeit, waarin het meel bezinkt. Van beide werkwijzen geeft Kauciern in I Celebes obygder II, afbeeldingen (zie de platen 120,121, 122). De laatst genoemde methode wordt toegepast bij het merg van den arenpalm, aangezien de vezels hiervan te hard zijn om met de hand te worden bewerkt.

Men vertelt dat zoowel de Metroxylon als de Arenga vroeger menschen zijn geweest; de eerste was een vrouw, de tweede een man. Dit echtpaar kreeg een kind, maar dit was een krokodil. Ze voedden het diertje eerst op in een kokosdop met water. Toen het voor deze ruimte te groot werd, bracht men het over in een trog, daarna in een grooteren bak, en eindelijk in een poel. De moeder was diep beschaamd over het feit, dat ze aån een krokodil het leven geschonken had, en ze verborg het diertje zorgvuldig voor de oogen der menschen. Eindelijk moest het dier naar zee worden overgebracht. Uit verdriet en schaamte wilde de vrouw nergens heen en ze bleef maar thuis zitten. Daardoor kon ze ook niet den akker bewerken. Om zich voedsel te verschaffen, schrapte ze zich het vuil van de armen, en bereidde het; dit was sago. Wanneer haar man thuis kwam, zette ze hem dit gerecht voor, en beiden aten het. Toen dit eenige dagen had plaats gehad, begon de man na te denken: Waar haalt mijn vrouw dit voedsel vandaan, want ze gaat er nooit op uit om iets te halen! Op een goeden dag bespiedde hij haar ongemerkt, en toen kwam hij tot de ontdekking, dat ze hem huidvuil te eten gaf. Hij verweet haar dit met scherpe woorden, zoodat de vrouw nog beschaamder werd, en in haar verdriet naar den vijver ging, waarin haar kind, de krokodil, een poos lang had geD1. 86 . 
leefd. Daar zat ze te treuren, en ze veranderde ten slotte in een Metroxylon. De man ging eens kijken waar zijn vrouw bleef. Van een hoogte af zag hij haar zitten aan den kant van het,water, en terwijl hij zoo op haar neerzag, schoten zijn voeten wortel, en veranderde hij in een Arenga.

$$
\text { Foejakloppen. }
$$

Vroeger behoorde tot het dagelijksch werk van de vrouwen ook het kloppen van boomschors, een werk dat door de meisjes van den tegenwoordigen tijd niet meer beoefend wordt. In alle dorpen der Loinangs, waar ik geweest ben, heb ik geen foeja meer zien dragen; maar in Simpang, dat zoo ver van het zeestrand ligt, moet nog foeja worden geklopt. Lieden uit Mantan vertelden mij, dat de mannen van Simpang hun eigen lendengordels kloppen met hamers van het hout van de wanga (Metroxylon elatum), uit de bast van den toengke'-boom. De vrouwen kloppen er hun eigen kleeren van de bast van den baa-boom. De geklopte bast, die voor kleedingstof geschikt is gemaakt, heet daar kahas.

Men gebruikte voor foeja de schors van de volgende boomen: $b a a$, toengke', en top. Wanneer de binnenbast van de buitenste schors gescheiden is, wordt de eerste met een houten klopper of knots murw geslagen. Zoo'n klopper heet ponteteki, en hiernaar heet het bewerken van boomschors tot kleedingstof monteteki. $\mathrm{Na}$ in het water te zijn uitgespoeld, worden de lappen boombast opgevouwen en in bladeren gepakt, ’aarna men ze drie dagen lang laat liggen om te fermenteeren. Daarna is de schors geschikt om met steenen hamertjes (evenals overal elders in Midden Celebes ike genaamd) op daarvoor bestemde planken beklopt te worden. Men maakte die steenen hamertjes zelf, en men verzekerde mij, dat er geen dorp of streek bestaat, waar men er het monopolie van had.

Alleen gedurende den rouwtijd voor een overledene was het verboden foeja te kloppen; op alle andere tijden was het geoorloofd. Van foeja werden gemaakt: lendengordels (petak) voor mannen, en tambio voor vrouwen; dit waren breede lappen foeja, die de vrouwen om het middel wikkelden. Verder maakte men singgan (Poso: siga) hoofddoeken, die door oudere mannen werden gedragen. Voor zoover ik heb kunnen nagaan, hebben de vrouwen vroeger haarbanden gebruikt: een lap foeja die tot een band werd opgevouwen; zoo'n band heet saladoeng. In de streek, die ik heb bereisd, heb ik geen 
enkele vrouw met zoo'n hoofdband meer gezien.

Verder maakte men grove sarongs (saleen) om daarin een en ander op den rug te dragen; 's nachts dekte men zich daarmede toe. Ook werden baadjes zonder mouwen vervaardigd, die pasanga heeten. Ten slotte nog sirihtasschen, poehihi, die ik nog door oude vrouwen zag gebruiken, evenwel niet van boombast maar van katoen gemaakt.

Het smeden van ijzer is onder de Loinangs geheel onbekend.

$\mathrm{Hu}$ isdieren; J a cht.

Opvallend is het gebrek aan huisdieren bij de Loinangs. Karbouwen heeft men niet en de enkele dieren, die aan het strand worden aangetroffen, zijn van zeer jongen datum. Dit is ook het geval met de weinige geiten, die er zijn. Deze heeft men pas leeren kennen, toen er Mohammedanen aan het zeestrand zijn komen wonen.

Huisvarkens heeft men ook nimmer gekend, en eerst sedert de Minahassische en Ambonsche goeroes onder hen varkens zijn gaan fokken, zijn enkele Loinangs hiermede ook begonnen.

In bijna elke kampong zijn een of meer gemsbuffels, onoeang, te vinden. Deze dieren die jong gevangen worden, zijn door langdurigen omgang met de menschen tam geworden, echter niet zóó, dat men ze los kan laten loopen. Men legt ze aan een stevig rotantouw vast, uit vrees dat ze weg zullen loopen, of dat ze kinderen met hunne scherpe horens zullen verwonden. Oude exemplaren zegt men laten zich niet levend vangen. Vooral in den ouden tijd ving men veel jonge gemsbuffels, want toen verbleef men de helft van zijn tijd in de wildernis, zegt men. Als men zoo'n tammen onoeang van een ander kocht, betaalde men daarvoor 2 blokken ongebleekt katoen (balasoe), en een met bloemen versierde, aarden kom, een totale waarde vertegenwoordigend van $\mathrm{f} 6 .^{\mathbf{1}}$ )

Hoenders zijn de eenige huisdieren, waarvan men het vleesch gebruikt. Eenig verhaal hoe hoenders zouden zijn ontstaan heb ik nergens gehoord. Evenals bij de andere volken op Celebes heeft de dagelijksche omgang met dieren de menschen er toe gebracht om op hun geluiden en gedragingen te letten, en daaruit allerlei gevolgtrekkingen te maken ten opzichte van het leven hunner verzorgers. $\mathrm{Er}$ bestaat een innige band tusschen menschen en hoenders, en de laatste kunnen een magischen invloed uitoefenen op hun meesters. Wanneer een kip een zoogenaamd hanenei legt, een ei dat zoo groot

1) Op fig. 137 in Kaudern's I Celebes obygder II ziet men een aangebonden onoeang afgebeeld. 
en zoo rond is als een flinke knikker, of een ei met een zachte schaal; dan noemt men dit nggaloe seoepit. Wanneer dit gebeurt, meent men dat een lid van' het gezin moet sterven, en daarom slacht men het dier spoedig. Dan komt iemand dit gezin van de magische smetstof, die door deze gebeurtenis op de menschen is gebracht, ontdoen door hen de plechtigheid van het piloeloeson te doen ondergaan, een handeling die we straks nader zullen beschrijven, wanneer we over de priesters en hun werk spreken. De priester, die dit werk doet, krijgt het schuldige hoen ten geschenke.

Ook wanneer veel hanen op een ongewoon uur in den nacht tegelijk kraaien, kololok oe manoe, zal er spoedig een doode zijn. Het komt er dan alleen maar op aan te weten waar het laatste gekraai is gehoord. Men zegt, dat al die kraaiende hanen vragen: „Waar is datgene wat stinkt?" en dat het de laatste haan is die antwoordt: „Hier in het huis van mijn meester”.

Wanneer hoenders op de nok van het huis paren (makantoboa), dan zal de eigenaar van die woning sterven; de beide schuldige hoenders worden dan gedood, en het kwaad dat de bewoners van dat huis is aangedaan, wordt door den priester weggenomen (poelias).

Een zeer bedenkelijk iets is het, wanneer een kip den inhoud van haar eieren opslurpt: dan zal iemand van het gezin sterven, zoodra de nieuwe akkers zijn aangelegd; de vogel wordt alleen dan pas gedood, wanneer hij bij herhaling zijn eieren ledigt.

$\mathrm{K}$ a t t e $\mathrm{n}$, toete, heeft men overal in de dorpen. Er bestaat een verhaal, waarin verteld wordt, dat een dorpshoofd krankzinnig werd en in dien toestand steeds zijnen lieden gelastte bamboe, awok, te halen. Hij zei niets dan ,,awok! awok!” En toen hij gestorven was veranderde hij in een kat. Men kocht een kat voor een stuk bijenwas (tahoe sangkolong). Men mag geen kaoe hanggi (Albizzia saponaria, waarvan de bast als zeep is te gebruiken), en geen langkoebobon-hout in huis brengen, want dit zou onvermijdelijk ten gevolge hebben, dat de kat uit het huis verdween. - Dit dier speelt overigens een zeer onbeduidende rol in het leven der Loinangs. Wanneer er een doode in huis is, moet men oppassen, dat de kat niet over het lijk springt of loopt, want dit zou ten gevolge hebben, dat het lijk zich oprichtte, en dan zou onvermijdelijk een mensch uit de omgeving moeten sterven (sommige Toradja-stammen gelooven, dat een doode zal gaan opzitten, als een hond over het lijk springt; de hond wordt dan gedood; bij de Loinangs wordt de kat niet gedood, als ze over het lijk springt). 


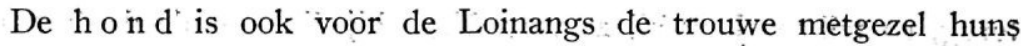
levens. Men kocht vroeger een hond met een van rotan gevlochten draagmand $(b a k i)$ of met van 1 tot 4 stukken was. Tegenwoordig volgt men een andere waardebepaling en de prijs wordt in geld voldaan. Met let ter dege op de teekenen, die het dier aan het lijf heeft. Het zijn niet de haarwervels, waarop men acht geeft, zooals de Toradja's doen, maar men kijkt uitsluitend naar de tepels van het dier: heeft het meer of minder dan 4 paar tepels, dan is het niets waard; maar zoo iets schijnt weinig voor te komen. Wanneer de tepels van een paar dicht bij elkaar staan, is dit een teeken, dat de hond goed is voor de jacht. Hoe verder de tepels van elkaar verwijderd staan, hoe minder het dier waard is. Wanneer het eerste paar tepels ver van elkaar staat, en het tweede paar op gelijke hoogte is met de punt van den penis, dan is dit een heel mooi teeken, en voor zoo'n hond wordt een hooge prijs gegeven. Staat het paar wat verder naar voren, dan loopt de hond gevaar door een gemsbuffel te worden gestoken. Heeft het dier een paar tepels op gelijke hoogte met den navel, dan zal het niet lang leven. Dit zal ook het geval wezen, als de hond een zwarte tong heeft: als hij zelf niet spoedig doodgaat, zal zijn meester sterven.

Heeft men een hond gekocht, en is men met het dier thuis gekomen, dan is het eerste wat men doet hem een snorhaar uit te trekken, welk haar men in de aarde van den haard begraaft: hierdoor zal de hond zich aan het huis hechten, en niet wegloopen. Bovendien schrapt de meester zich wat eelt van handpalm en voetzool, en schaaft wat houtvezels van de scheede van zijn hakmes, en dit alles mengt hij in het voedsel van den hond, waaraan hij ook nog wat van zijn speeksel toevoegt. Dit zal het dier aan den meester hechten, zoodat het hem overal naloopt.

Men mag niet met een hond omgaan, alsof hij een mensch ware, en men mag geen grappen met hem uithalen. Dit geldt trouwens van alle dieren. Het gevolg zou zijn, dat zware regen komt, of dat de aarde inzakt, of dat men in steen verandert. Een paar voorbeelden er van mogen hier volgen: $O p$ den weg van Lingketeng naar Kintom is een groote steen, waarvan men het volgende vertelt: $\mathrm{Er}$ was eens een jager die Toena heette. Op jacht zijnde werd hij door een regenbui overvallen, en daarom zocht hij een schuilplaats onder pasgenoemden steen. Daar maakte hij vuur aan en warmde zich. Zijne honden kwamen er ook om heen staan, maar de baas joeg ze weg om alleen van de warmte te genieten. Telkens kwamen de dieren 
terug, en telkens joeg hij ze weg. Toen hij dit voor de derde maal had gedaan, opende een hond den mond en zeide: „Wat moeten we dan nu doen?" Op datzelfde oogenblik viel de steen over den jager heen, en hij zelf veranderde in steen. Maar men moet niet naar den steen gaan kijken, want dan zou het hard gaan regenen.

Een andere plek waaraan een verhaal verbonden is, waarin met dieren wordt gespeeld, is het meertje Ansamboelang boven Lembangan. Daar was vroeger een dorp, waarin Tama Oengkoei woonde. Hij was een oude man, die zou trouwen met een jonge vrouw, Popiisi genaamd. Popiisi wilde den ouden man niet, maar de familie dwong haar tot het huwelijk. Popiisi's hart hing aan een anderen man. $\mathrm{Zij}$ besloot nu om de krachten der natuur in beweging te brengen om haar van den ouden man te verlossen. Op den huwelijksdag ving ze een garnaal en een kreeft, en stopte die te zamen als een echtpaar in een gat in den paal van de woning. Verder deed ze een kippenei in de wrong van haar hoofdhaar (dit laatste waarschijnlijk om zich van meer levenskracht te voorzien). Toen het avond geworden was, heerschte er groote vreugde op het feest; men danste, zong en lachte. Maar het duurde niet lang of water begon uit de aarde op te spuiten. Niemand merkte er iets van behalve Popiisi, die er op had gewacht. $\mathrm{Ze}$ waarschuwde haar vrijer, en samen namen ze de vlucht. Het duurde niet lang of de grond stortte in en op de plek ontstond een meer.

$\mathrm{Na}$ deze uitweiding keeren wij tot den hond terug.

Wanneer een hond, die zijn baas veel voordeel heeft aangebracht, doodgaat, wikkelt zijn meester hem in een lap katoen, en legt hem op een tak van een boom, of op een orchidee (dampe), die op den stam van een boom groeit. Het lijk van een hond mag nooit in den grond begraven worden, want hierdoor zou de dapperheid van de andere honden verdwijnen.

Mannen eten hondevleesch; vrouwen niet, want als ze dit doen, zal haar hoofdhaar titvallen. Ook priesters eten geen hondevleesch. Het mocht wel in huis worden gebracht, en op den haard klaargemaakt; maar alleen mannen deden dit werk. Het moest in bamboe kokers worden gestoofd, en uit bladeren en kokosdoppen worden gegeten, die na het gebruik werden weggeworpen; want potten, kommen en borden, die met hondevleesch in aanraking zijn geweest, zijn voor ander gebruik ongeschikt geworden. Men doodt alleen honden die voor de jacht van geen nut zijn, of die door het wild zoodanig verwond zijn, dat men ze niet meer in het leven kan be- 
houden. De baas van den hond eet meestal niet van het gerecht mee. Als offer wordt een hond nimmer gedood.

Wanneer honden in huis paren of met hun achterste over den vloer der woning schuren, heeft dit in tegenstelling met het geloof bij de meeste andere stammen, die Midden Celebes bewonen, niets te beteekenen. Wanneer de hond in den nacht een huilend geblaf aanheft, mohoeakon of toemoon, dan ziet hij een ziekte aankomen, zegt men. Of hij ziet een doodenziel die een levende komt halen. Heft hij dit gehuil in huis aan, dan valt de doode in het dorp; laat hij dit geluid buiten hooren, dan zal iemand sterven in de woning, waarheen de snuit van het dier gericht is. Als een hond bizonder veel wild vangt, zoodat zijn meester nooit vergeefs er op uitgaat, dan ziet men hierin niets goeds. Dit toch bewijst, dat de hond medelijden heeft met zijn baas, omdat hij ziet dat deze spoedig zal sterven. Bij wijze van troost (poinakalon) voorziet het dier hem flink van wild, opdat hij zich vóór zijn heengaan nog eens te goed kan doen. Men ontdoet zich niet van zoo'n hond, want hiermede zou niets aan het noodlot veranderd worden; integendeel stelt men zoo'n dier op hoogen prijs, èn om de gehechtheid, die hij voor zijn meester toont, èn om het voordeel dat hij aanbrengt.

Het gebeurt ook nu en dan, dat de honden herhaaldelijk niets vangen, en de Loinang merkt dit aan als het gevolg van een ban, die op de dieren is gelegd. Deze ban kan door twee oorzaken ontstaan: de eene reden is, dat een doodenziel de honden belet te vangen, ze betooverd heeft. Dit heet oemasaa. Sommigen beweren medicijn te hebben om dien tooverban op te heffen; deze medicijn wordt in kleine stukjes gesneden, en in het voedsel der honden gemengd. Deze wijze van behandelen noemt men oboeloki; de medicijn heet pomboeloki. In Lingketeng kent men ook andere middelen, pontoeloi, waarbij den honden medicijn in de oogen wordt gedaan.

Maar de gewone manier om ze te onttooveren, zoodat ze weer vangen, is om ze in de rivier onder te dompelen, olomosi. Men brengt den hond aan den oever van de rivier, en licht hem bij het vel aan den nek en aan de billen op. Dan dompelt men het dier viermaal in het water met den kop naar de monding van den stroom gericht, en dan doet men hetzelfde nog eens driemaal met den kop naar den oorsprong van de rivier gewend. Als men het dier na zijn bad loslaat, en het schudt zich dadelijk het water van het lijf, dan zal het weer vangen; maar loopt het weg zonder zich te schudden, dan kleeft de ban nog aan hem, en hij zal nog niets vangen. 
Gewoonlijk gaat deze nadeelige invloed op de honden uit van een sterfgeval, waarvan men nog niet heeft gehoord. Eertijds toch bleef men weken lang in het bosch jagen, en dan kwam het meermalen voor, dat in dien tijd iemand thuis stierf. Wanneer het pas beschreven olomosi „ondergedompeld worden” geen resultaat had, zat er niets anders op dan naar huis terug te keeren. Als men wist wie de overledene was, die hun deze parten had gespeeld, was zijn invloed op de honden ook tevens opgeheven. Daarna kan men dan met hoop op zegen er weer opnieuw op uitgaan.

De tweede reden waarom honden geen geluk hebben op de jacht is, omdat de lieden van het gezin, waaraan de hond toebehoort, iets gedaan hebben, waardoor ze het geluk der dieren hebben bedorven. Zoo mag men den stok, padoho, waaraan het varken gehangen heeft, toen men het zijn borstels boven het vuur zengde, niet doorhakken of als brandhout gebruiken; dit zou ten gevolge hebben dat de dapperheid der honden verdween. - Het vleesch van gemsbuffels wordt op een rek (Baloa: tanggaoean, Lingk. : tapaan) gelegd, en daaronder wordt vuur aangemaakt om het vleesch te rooken. Dit rek is aan rotanlijnen opgehangen; als men de hut verlaat, verbergt men het rek ergens in 't bosch; want als een ander het hout, waarvan dit rek gemaakt is als brandhout gebruikte, zouden de honden van hem, die het rek gemaakt heeft, niet alleen niets vangen, maar de dieren zouden kans loopen door de horens van een gemsbuffel, of door de slagtanden van een wild zwijn gedood te worden. Wanneer het bekend wordt, dat een jager het droogrek van een ander als brandhout heeft gebruikt, wordt hij beboet, want hij moet alle schade betalen, die den eigenaar van het rek is of zal worden toegebracht, hetzij in zijn geluk, hetzij in zijn honden.

Ook wanneer de jachtbuit verkeerd verdeeld is (waarover straks meer) zal daarvan het gevolg zijn, dat de honden niets meer vangen. Of wanneer de ingewanden van het wild niet volgens den regel zijn behandeld. Niet alleen zullen de honden dan niets meer vangen, maar de jager zal telkens verkeerd stooten met zijn speer, en boomen raken in plaats van het wild.

Het is ook verboden om van stukken wildbraat, die men aan een spit, pohahang, heeft geroosterd, brokken af te snijden, terwijl het vleesch nog aan het spit zit. Men moet er de stukken eerst met de hand aftrekken, en dan mag men ze pas aansnijden. Acht men niet op dit voorschrift, dan is weer het gevolg, dat de honden onder een ban raken, waardoor ze niet in staat zijn iets te vangen. Het vleesch 
op den rand (tangon) van den haard in kleine stukken hakken, is ook verboden, maar niet met het oog op het jachtgeluk der honden; wanneer men zoo deed, zou men kans loopen om door een krokodil gegrepen te worden, als men aan het zeestrand komt.

Om het kwaad waardoor de honden bevangen zijn geraakt weg te nemen, zoodat de honden het wild weer zullen pakken, neemt de aanvoerder van den troep een bamboe van 4 geledingen: de eerste geleding legt hij in het vuur, en zegt daarbij : „Als we den buit verkeerd verdeeld, of fouten begaan hebben bij de behandeling van de ingewanden, dan moge dit kwaad in den bamboe gaan". Als dan de eerste geleding met een knal is opengesprongen, schuift men achtereenvolgens de andere geledingen in het vuur. Wanneer geen enkele geleding met een knal openspringt, behoeft men voorloopig niet op succes te hopen. Springen er slechts 1 of 2 open, dan zal men wel weer geluk hebben, maar pas over enkele dagen. Ontploffen alle 4 geledingen, dan zal men dadelijk geluk hebben, zoodra men er weer op uittrekt. Deze handeling heet mompogoali.

In Lingketeng gaat men nog op een andere wijze te werk, namelijk door ponggeges: Men neemt dan een bos onkruid, en draait deze viermaal over den kop van het dier heen. Dan strijkt men hem daarmee over de borst, verder over den buik, tusschen de achterpooten door over den rug en den kop, waarna de bos onkruid wordt weggeworpen. Door deze handeling strijkt men het kwaad, dat den honden belemmerd heeft te vangen, van hen af. De lieden van Baloa erkennen, dat dit ponggeges een afdoend middel is, maar ze willen het niet toepassen, want, zeggen ze, daarna zullen de honden wel is waar weer vangen, maar als een der dieren, die op deze wijze behandeld is, gestorven is, żal men geen goeden hond meer in diens plaats krijgen.

Ik zeide reeds, dat men vroeger soms weken achtereen in de bosschen verbleef oni te jagen. Men gaat altijd in gezelschap van anderen, en de troep staat onder leiding van een aanvoerder, den tonaas. Deze aanvoerder behoeft geen bezitter van honden te zijn; de anderen kieżen hem tot tonaas omdat hij om de eene of andere reden vertrouwen wekt. Gaan b.v. eenige broers samen jagen, dan is het meestal de oudste hunner, die als aanvoerder optreedt. De aanvoerder mag niets van de ingewanden van het wild eten; hij mag ze zelfs niet zien. Daarom wordt een varken of een gemsbuffel, die men heeft gedood, steeds op eenigen afstand van de hut, waarin de aanvoerder zich bevindt, ontweid. Wanneer de tonaas de ingewanden van het wild te zien kreeg, zou men geen geluk meer op dezen tocht hebben. Bij 
de verdeeling van den buit krijgt de aanvoerder een grooter deel dan de anderen. Hij heeft twee assistenten, de pombebe'i en de pahemata, evenals de aanvoerder in den krijg die heeft; bij de jacht hebben deze assistenten echter niets te beteekenen.

Voordat men ter jacht gaat, wordt wel eens gewicheld met een pinangnoot om te zien of men geluk zal hebben. De noot wordt gekloofd, en dan kijkt de jager hoe de roode aderen op het snijvlak loopen. Wanneer een paar aderen van den rand uitgaande elkaar in het midden raken, dan is dit een zeer gunstig teeken. Wanneer geen roode aderen van den rand naar binnen uitstralen, zal men niets krijgen. Het bekijken van het ingewand van een hoen of varken, om daaruit te kunnen opmaken of men geluk dan wel tegenspoed zal hebben, een methode die bijna overal bij de Toradja--stammen toepassing vindt, kennen de Loinangs niet. Alleen wanneer een varken is neergelegd, en het dier is geslacht, kijkt men naar de galblaas: als deze goed gevuld is, en dus uitpuilt, zal men spoedig weer een varken machtig worden; de honden zullen dan alles pakken wat ze vinden.

De aanvoerder is het die op de teekenen let, welke nagenoeg de zelfde zijn als die waarop acht gegeven wordt als men ten strijde trekt; ik kom hierop beneden uitvoerig terug. De aanvoerder vraagt aan den Aardgeest, toempoe noe tano, die als de eigenaar van het wild wordt beschouwd, om geluk. Wanneer de troep jagers namelijk in dat deel van het bosch gekomen is, waar men zijn geluk zal beproeven, wordt eerst een hut, ilion opgericht. Wanneer men hiermee gereed is, wordt een bamboestaak in den grond geplant, waaraan een streng sole-vruchtjes (Coix lacryma Jobi, waarvan de witte korrels aan een koord geregen worden, en als halssieraad worden gedragen); verder wat pisang, mais, cassave, sirih-pinang, een houten zwaard en een houten speer. Dan roept de aanvoerder den Aardgeest, toempoe noe tano, of den Boschgeest, toempoe no ngapa, aan, en vraagt hem om geluk. Dit doet hij tegen het vallen van den avond, en gedurende den nacht wordt op de vogelgeluiden gelet. Als de eketi (een kleine uil, die in Poso totokesi heet), de laoentoka of de kiposo zich laten hooren, dan voorspelt dit geluk; men zal dan elken dag wat vangen. $\mathrm{Er}$ is een vogel, de mongkö̈k, die een groote rol speelt in de gedachtenwereld van de Loinangs (we zullen het beneden nog meermalen over hem hebben). Wanneer deze vogel ki-koko! roept, noemt men dit melawa, en dan gaat men er den volgenden dag niet op uit, want dan is men overtuigd, dat men niet alleen geen geluk zal heb- 
ben, maar de jagers loopen ook kans om gewond te raken. Eerst wanneer gunstiger geluiden zich hebben laten hooren, trekt men er weer op uit.

De jagers mogen geen tongkoeasi eten, een kleine soort paddestoel, tomboelo'on, een groote soort paddestoel en geen hongohoet, een bladgroente, die geplant wordt, maar die ik te voren nog nimmer gezien heb (Ook de mij vergezellende Posoër kende de plant niet). Wanneer ze zich niet aan dit voorschift houden, willen de honden het wild niet pakken.

Als men een varken heeft buitgemaakt, moet men de regels voor de behandeling van het wild goed in acht nemen. Brandt het vuur flink, dan wordt eerst de kop van het varken daarboven geschroeid; daarna worden de borstels van de rechterzijde gezengd, vervolgens die van den linkerkant, van den rug, en ten slotte van den buik. Dan wordt het dier met een scherp gemaakt stuk hout of bamboe afgeschrapt. Zoo'n schrapper heet koekoes, en deze wordt na gebruikt te zijn, in het dak van de hut gestoken, want er mag niets mee gebeuren, of dit zou weer van nadeeligen invloed zijn op het jachtgeluk. De schrapper mag voor meerdere dieren gebruikt worden, maar de stok (padoho), waaraan het dier hangt, terwijl de borstels worden geschroeid, moet voor elk zwijn een ander zijn.

$\mathrm{Bij}$ het slachten mag men ook geen fouten begaan, sala sampan of sala sehe, want daarmee zou men weer zijn geluk verspelen. Men moet de darmen niet uit elkaar halen, maar op een hoop laten liggen; men mag de spier van het aarsgat niet doorsnijden, maar men moet er om heen gaan met het mes.

De honden krijgen een deel van het borstbeen, ocbak oe dada, en een stuk van het buikvleesch beneden den navel; dit heet nggalaoenjo. Verder zijn de halswervels, poloan, voor hen. Dit aandeel van den buit voor de honden heet doso oe dedeng. Het hier gezegde wordt door de lieden van Baloa gevolgd. In het Lingketengsche krijgt de hond, die 't eerst het wild heeft aangeblaft, de galblaas, pooe, met bloed uit 't hart, soele; verder krijgt elke hond vier stukjes, koejoe, van de longen.

Ik zei boven reeds, dat het niet eerlijk afstaan aan de honden van hun deel ten gevolge heeft, dat ze niets meer vangen. De kop van het wild is voor den eigenaar van de honden, die het dier hebben aangegrepen; alleen als men een varken buit maakt in de nabijheid van het dorp, is de helft van den kop voor den meester der honden, en de andere helft is voor het dorp. Verder krijgt hij een stuk van de 
lever (bonoea noe pooe, lett. woning van de galblaas), het hart en het nekbeen (tempasang), en het vleesch met vel van de borst, dat talianannjo heet. Deze vijf dingen heeten doso' olima, of pokonaan. De huisgenooten van den jager mogen van deze doso' mede eten, maar lieden uit andere gezinnen niet.

Overigens wordt de buit gelijkelijk onder de jagers verdeeld, of ze honden bezitten, of niet; alleen krijgt de aanvoerder een grooter deel, zooals reeds is gezegd.

Ook de aard- en de boschgeesten worden niet vergeten. Een oor en de staart van het wild worden met een rotan aan de tak van een boom opgehangen, in de richting van de plek, waar men het wild gekregen heeft. De aanvoerder spreekt daarbij: „Dit is voor $\mathbf{u}$, Toempoe noe tano, opdat ge ons morgen en overmorgen weer wild zult geven.

Om zijn jachtgeluk niet te bederven moet men vermijden een aantal woorden uit te spreken, terwijl men in het bosch is; daarom heeft men die door synoniemen vervangen. Wanneer men zich hieraan niet houdt, zou er zwaar weer komen: hevige regens van onweer vergezeld zouden dan neerdalen. De voornaamste van deze woorden zijn de volgende: Voor manoek, ,hoen”, zegt men: siboeoet; voor oelo ,slang”: no'as; voor oehang ,garnaal": kohoka; voor toete ,kat”: toempoe noe poloe; voor bonoea ,huis": soong; voor booene ,,vrouw": penengkoehang; voor boko ,schildpad": pintiisan; voor minanga „riviermonding”: kalangaan; voor kahambaoe „karbouw”: kokapi; voor tigo ,tabak": loemoet; voor gohoeng ,donder": kaoe motoea; voor ikan ,visch": loobang; voor tindoli ,paling": kohoeoi; voor adjahan ,paard": djalan; voor koehon ,kookpot”: pesaak; voor timoeson „zout": koteeon; voor malisa „Spaansche peper”: kosehon; voor pilon „kalk”: pongaboe'i; voor dochian „doerian”: kaoe mahii. De woorden voor varken, gemsbuffel, man regen, zon, maan, speer, vuur, en de benamingen voor handelingen blijven onveranderd. Bij de lieden van Baloa zijn de oogsttaal en de jachttaal dezelfde.

Men jaagt op varkens en op gemsbuffels. De babi roesa (bajangoa of sangkoboeloe) moet veel voorkomen aan den bovenloop van de Toimaa. Ze worden meermalen gedood door lieden van de Lingketeng-clan, als ze in genoemde streek rotan gaan zoeken.

Zooals ik reeds zeide wordt het vleesch van varkens en gemsbuffels gerookt, waarna de stukken in bamboe kokers worden gedaan, die daarna stevig met de bladeren van den Livistona rotundifolia worden toegebonden; daarover heen gaat weer een deksel van de bladscheede 
van den pinangboom. Zoo'n koker heet binoentoen, en het vleesch 1)lijft, op deze wijze bewaard, maanden lang goed. Men maakt de kokers van gelijke grootte, opdat ze gemakkelijk onder de jagers kunnen worden verdeeld. Zoo'n bamboe met vleesch heeft een waarde van 1 pehe-peheet, een soort aarden kom, die sedert langen tijd niet meer wordt ingevoerd; of 1 blok ongebleekt katoen (balasoe).

Jonge onoeangs worden gevangen en mee naar huis genomen; ze worden gevoed om bij gelegenheid van eene of andere feestelijkheid of plechtigheid te worden gedood. Men mag het dier dan niet den hals afsnijden, maar men moet het met een speer steken, zooals men op jacht zijnde doet. Als men dit niet deed, zouden de honden sterven, omdat ze hun aandeel, de doso' noe dedeng, niet zouden krijgen langs den gebruikelijken weg.

Wanneer een getemde onoeang aan een ander wordt verkocht, moet er bij den prijs ook een kom zijn, zooals boven is genoemd; deze kom heet botoe toeboeng ,,voor het verbreken van de lijn” (waarmee het dier is vastgebonden). De kooper moet ook beloven het dier met de speer te zullen dooden. Als men een onoeang heeft gedood, wordt het dier niet gevild, maar men hakt het in stukken met de huid er aan. De waarde van dierenhuiden voor den handel heeft men pas in later jaren leeren kennen. Tot op den huidigen dag echter vilt men onoeangs niet, omdat men juist de huid bizonder lekker vindt. Alleen de huiden van herten worden gedroogd en verkocht.

Op de groote jacht wordt het blaasroer, sopoet, niet meegenomen. Dit wapen wordt evenals bij de Toradja's van twee geledingen van de bamboesa longinodes gemaakt, welke stukken precies op elkaar passen. Zoo worden ze in een wijderen bamboe van dezelfde soort geschoven, zoodat ze een recht kanaal vormen van circa 1 vadem lengte. De pijltjes heeten hihis; ze worden van bamboe gemaakt; om de punt van het pijltje maakt men een insnijding, zoodat deze in het lichaam van het dier afbreekt; men snijdt er ook wel eens een weerhaakje aan. Het pijlgif is het sap van den djalit-boom, de Antiaris toxicaria. Dit sap vermengt men met dat van de rotanplant, dat lambangasoe heet, waarna het met een kippeveer op de punten der pijlen wordt gestreken. Alle mannen kunnen met het blaasroer schieten. Ook op het oorlogspad neemt men het blaasroer niet mee. Men moet oppassen om in de buurt van blaasroerpijltjes geen cassave te eten; ook moet men er voor waken, dat het blaasroer niet in aanraking komt met longgolia-hout, want in beide gevallen zal het 
pijlgif krachteloos worden. Dit zal ook het geval zijn, wanneer een vrouw over den koker met pijlen stapt. Met het blaasroer wordt op vogels, apen, cuscus geschoten.

Het gebruik van pijl en boog kent men niet; ook niet als spel, alleen weet men te vertellen, dat de Tobeloreezen deze wapens gebruiken.

Men kent allerlei middelen om wild te bemachtigen. Aangepunte bamboes, die schuin in den grond worden gestoken op het pad, waarlangs varkens gaan, met de bedoeling dat ze er tegenaan zullen loopen, en doodelijk verwond worden, heeten hamba (Poso: ampa). Een springlans, die op zulk een wijze met een veerkrachtige lat is verbonden, dat ze losschiet, en in het lichaam van het wild dringt, zoodra dit tegen een daarmee verbonden lijn loopt, heet botikan (Poso : watika; voor de beschrijving er van zie men Toradja's II, 365). De plek waar men zoo'n springlans heeft opgesteld, of scherpe bamboes in den grond heeft geplant, moet men aanwijzen door middel van een stok, dien men in den grond steekt, en aan het boveneinde splijt; in die spleet klemt men een plankje, waarmee de richting wordt aangegeven, waarin de gevaarlijke dingen zich bevinden. Zoo'n waarschuwingsteeken heet bateak (in het Bare'e is bate een opgerichte stok als kenteeken van het een of ander); heeft men er een bos geknoopt gras in geklemd, dan heet het oloet (in het Bare'e is ojoe „knoop”).

Een strik voor muizen heet sidi (Poso : sigi; voor de beschrijving zie Toradja-boek II, 367); een dergelijke strik voor eekhorens (djo'oe), cie op de takken der boomen wordt opgesteld, heet ampa. Het vangen van boschhoenders door middel van een tammen haan, die te midden van een aantal opgezette strikken zijn wilde makkers lokt door zijn gekraai, en dan met ze gaat vechten, zoodat ze met hun pooten in de strikken verward raken, heet montambat (Poso: bantara; voor de beschrijving zie Toradja-boek II, 368). Muizen in huis en op den grond worden gevangen met een bamboe, waarin een strik is aangebracht ; zoo'n voorwerp heet tolo (Poso : tojo, beschrijving : Toradjaboek II, 369). Sommige muissoorten worden gegeten, andere niet; onder de laatste behoort de pongka, die een halfwitte staart heeft.

In het Loinangsche komen beide buideldieren voor, die ook in het overige Midden Celebes gevonden worden: de koese (Phalanger ursinus, of buidelbeer), en de bolotok (Phalanger celebensis, of buidelrat; de Loinangs rekenen dit dier tot de muizen). Dé buidel heet kandoengannjo. 


\section{Cosmos en Schepping; Geestenwereld.}

De voorstellingen omtrent den cosmos en de schepping van aarde en schepsels zijn zeer schaarsch, wat van een volk dat nog niet lang geleden zoo'n sterke vermenging heeft ondergaan, wel te verwachten is. Wellicht dat de lieden van Simpang nog meer van de oorspronkelijke overleveringen hebien bewaard, waarvan bij de meer gemengde bevolking nog slechts magere resten zijn overgebleven. Men spreekt algemeen van Toempoe ,de eigenaar”, als van den Urheber van alle dingen, maar hoe hij alles zou hebben gemaakt, daarvan maakt men zich geen voorstelling. Men kent van hem alleen de uitdrukking: „Toempoe die de vingers en de teenen vaneen gespleten heeft" (een zegswijze die bij alle Toradja-stammen in gebruik is). Op mijn vraag hoe hij de menschen geschapen heeft, kreeg ik tweemaal het volgende antwoord: Wanneer man en vrouw cohabiteeren, dan is Toempoe in den man, en hij is in de vrouw, en daaruit ontstaat het kind.

Het uitspansel noemt men lajano, waar wezens of geesten wonen, die bij het einde der wereld (kiama) de koorden doorsnijden, waarmee de aarde aan het uitspansel hangt. De ruimte onder de aarde heet babatoengo; daar wonen ook wezens, maar dezen hebben geenerlei gemeenschap met de aardbewoners. (Wij hebben hierin misschien een overblijfsel te zien van een geloof van de oorspronkelijke bewoners in een onderwereld, waarheen de zielen der afgestorvenen gaan). Nergens kende men een verhaal, dat de hemel eertijds dicht op de aarde zou hebben gerust, of dat er een trap naar den hemel zou hebben bestaan. Alleen zou men uit de mededeeling, dat de berg Lokait ontstaan is uit een rotan, die naar beneden stortte, kunnen afleiden, dat deze rotan eertijds de verbindingsweg kan zijn geweest tusschen hemel en aarde.

Naar de voorstelling der ongeschoolde Loinangs rust de aarde op een waringin-boom (noenoek); wanneer een buffel zich tegen den boom schuurt, schudt deze en daardoor ook de aarde, die op hem rust. Sommigen voegen er nog aan toe, dat de eigenaar van den buffel Baginda Ali is. Bij aardbeving (loeloe') roept men : tano madodo ,de aarde is stevig”. Men trekt onkruid uit den grond, en de op deze wijze verkregen kruiden zouden een uitstekend middel zijn tegen malaria. Want het beven van de aarde wordt in verband gebracht met het beven van het lichaam bij een koortsaanval. De eieren die tijdens een aardbeving in de nesten der kippen hebben gelegen, worden opgegeten, opdat er geen kuikens uit voort zullen komen 
(gewoonlijk zegt men, dat zulke eieren niet kunnen gelukken, maar de Loinang zegt dit te willen voorkomen). Op den dag, die op een aardbeving volgt, moet men niet op reis gaan, want dan zou men niets dan nadeel ondervinden. Vooral het uittrekken ten strijde was op dien dag verboden.

Van zon (sina) en maan (bitoe'on) maakt men zich de voorstelling, dat beide met elkaar getrouwd zijn. De zwarte figuur in de maan houdt men voor een jager met 7 honden. Bodoeng heet deze man. $\mathrm{Hij}$ had eens den heelen dag met zijn honden in het bosch rondgezworven zonder iets te vangen. Moedeloos legden hij en zijn dieren zich eindelijk bij een grooten steen te slapen. Gedurende den slaap kleefden ze aan den steen vast, en zoo ziet men ze nog in de maan.

Een verduistering, hakomon, van de maan ontstaat door een draak, naga, die het hemellichaam wil verslinden. Wanneer zoo iets plaats heeft, graaft men snel een gat in den grond, legt daarover de bladscheede van den sago, en tokkelt er op. Ook op trommen, rijstblokken en andere voorwerpen wordt geslagen. Men roept naar boven: Loeaakon mae intan mami ,spuw onze parel uit". Verduistert de zon, dan zegt men dat ze copuleert met de maan, want de zon wordt als man gedacht. Men slaat dan ook op allerlei voorwerpen om door het geraas de zon te bewegen weer te voorschijn te komen.

Voor den bliksem, kilat, is men zeer bevreesd. Wanneer men om een dier lacht, gelooft men, dat men door den bliksem zal worden getroffen. Wordt een hoom door het hemelvuur geraakt, dan neemt men wat van zijn hout, en draagt dit bij zich, niet alleen om tegen het hemelvuur beschermd te zijn, maar zoo iets acht men voor de meest uiteenloopende doeleinden nuttig.

Ook het gezicht van een regenboog, tandalo, wekt geen gevoelens van bewondering, maar alleen van vrees op, want met den regenboog is een geest verbonden, de setan noe tandalo, die een nijdigen aard heeft. Als een regenboog op een boom rust, houdt men zich overtuigd, dat in dien boom een machtige geest woont. Men komt dan liefst niet in de buurt er van, vooral niet met een kind, want dit zou met zijn nog zwakken levensgeest ziek worden. Wanneer men onder een regenboog heen gaat, moet men onvermijdelijk ziek worden : het lichaam zet dan op. Alleen de priester, bolian of boehake, kan de ziekte cureeren. Op het oorlogspad zijnde trok men zich niets van een regenboog aan; want door de ceremoniën, die men heeft doorgemaakt, voordat men op weg ging, had men zich zóó sterk gemaakt, dat dit verschijnsel de strijders geen kwaad meer kon 
doen. Maar bevond men zich op een handelstocht, of was men op den akker bezig, dan moest men dadelijk ophouden bij het verschijnen van een regenboog. Wanneer de voet van den regenboog in het dorp rust, heeft dit geen bizondere beteekenis. In 't algemeen is het geraden om niet naar een regenboog te kijken, dan kan hij ook geen invloed op $\mathbf{u}$ uitoefenen; nog minder moet men naar hem wijzen, anders zal de vinger krom blijven staan. Men spreekt van den regenboog als van een omslagdoek of de vlag van een boozen geest, setan.

Onder de geesten, aan wie men gelooft, spelen de boenake en de djin de voornaamste rol. Woerake is een naam die bij de Bare'e sprekende Toradja's gegeven wordt aan de geesten, die tusschen hemel en aarde wonen, en die zich in menschen (priesters en priesteressen) incarneeren, en langs dezen weg aanwijzingen geven voor het genezen van zieken. Volgens de verklaring van Dr. Adriani zou het woord beteekenen ,floep, naar boven”, en dit zou dan slaan op de omstandigheid, dat de ziel van de Pososche priesteres in een oogwenk in gezelschap van zulk een geest naar het luchtruim opstijgt om daar den Hemelheer om levenskracht voor den zieke te vragen. Djin is een Arabisch woord voor geesten, dat via het Boegineesch zijn intocht in de talen van Midden Celebes heeft gedaan. Sommigen zeggen, dat boehake geesten zijn van de zee, die met de immigranten mee zijn getrokken naar het binnenland. Jacob Koetondong van Tamboenan vertelde mij, dat boehakc de geesten zijn van poita, zeesterren met 5 armen. Hij beweerde, dat deze zeesterren heel groot kunnen worden, en dan zijn ze in staat een prauw om te keeren; zulke groote zeesterren heeten mokoloimboe. Ze hechtten zich vast aan alles, waarmee ze in aanraking komen; zoo doet ook de bochake: deze klampt zich vast aan elken mensch, dien hij ontmoet. $\mathrm{Op}$ het land wonen de boehake in rivieren en op groote boomen.

De djin daarentegen zouden juist van het land komen; ze wonen in rivieren en op bergen, vooral op steile afhangen. Bochake zouden dus zeegeesten, djin landgeesten zijn. De djin wonen in den hemel, en daar ,geven ze de hand" aan den Hemelheer, Alahoe taala of Toempoe, d.w.z. ze staan steeds met den Oppersten Geest in gemeenschap.

De djin en de boehake dragen namen, zooals Bahaelan, Bombange, Pondjongoe Toimaa, Pongkeali, Mata ngkalana, Oewaloek matanjo, Mandja, Halap, Tombaja, Djoeroe toelis, Kota, enz. Zoowel djin als bochake bezielen de priesters; in de praktijk zijn beide soorten D1. 86 . 
van geesten gelijk, en een oude man te Pinapoean vertelde mij dan ook, dat het twee namen zijn voor dezelfde zaak. Daar men het bijna altijd over boehake heeft, en djin weinig gebruikt wordt, zal ik mij in 't vervolg alleen van eerstgenoemd woord bedienen.

Wanneer de boehake in huis komt, zet hij zich neer op de oliboeboes. Dit is een blad van de Livistonia rotundifolia, dat omgebogen is in den vorm van een waterschepper, en wel op zulk een wijze, dat de uiteen gerafelde kanten van het blad aan beide zijden van het l,akje als franje neerhangt. Bij elke gelegenheid van belang waarbij de priester te pas komt, wordt een nieuwe oliboeboes gemaakt, die bij de andere wordt opgehangen. Verhuist men naar een andere woning, dan gaan al deze offerbakjes mee. Wordt het aantal van deze dingen te groot, dan vinden de oudste, half vergane oliboeboes een plaats buiten aan den wand van het huis, als men maar oppast, dat ze niet door regen nat kunnen worden. In het nog heidensche Mantan zag ik hier en daar heele bossen van die dingen buiten aan de huizen hangen.

In deze oliboeboes zet men een aarden bord, en daarop worden offers voor den boehake gelegd: sirih, pinang en een ui; geen tabak legt men er in. Wanneer men zich onwel voelt, vernieuwt men het offer in de oliboeboes om te voorkomen, dat men ziek zal worden.

Vindt men de oliboeboes in elke woning van Heidenen, een andere soort verblijfplaats van geesten, de malige-lige treft men slechts aan in de huizen der priesters. Dit zijn vier houten plankjes, die in een vierkant aan elkaar zijn gevoegd, en in dit vierkant heeft men een vloertje aangebracht van bamboe latjes. Dit voorwerp is aan vier touwtjes opgehangen, die van de vier hoeken uitgaan. En dan is er nog een geestenwoning, die salogan heet; deze is op dezelfde wijze gemaakt als de malige-lige, alleen met dit onderscheid, dat aan de vier hoeken een bamboetje afhangt, welke bamboes de palen van het geestenhuis moeten voorstellen. Dit laatste voorwerp vindt men alleen in de woning van een hoofdpriester, een man dus voor wien de geestenwereld geen geheimen meer heeft. Waar een salogan is, wordt geen malige-lige meer gebruikt. Ik geloof, dat de malige-lige alleen bij de Baloa-menschen bekend is, en dat de Lingketeng-clan alleen de salogan naast de oliboeboes gebruikte. Daar de leden van deze clan allen tot het Christendom zijn overgegaan, en alle voorwerpen van den heidenschen eeredienst verwijderd zijn, kon ik hierin geen zekerheid krijgen. Dit is vast te stellen, dat de oliboeboes de offerplaats is voor de boehake in het algemeen, geesten zonder naam; 
vandaar dat er telkens nieuwe bij gemaakt worden. Maar de maligelige en salogan zijn de verblijfplaatsen van bepaalde boehake of djin, die een naam dragen, en die den priester komt bezielen als deze hem te hulp roept. ${ }^{1}$ )

\section{De Priester en zijn werk.}

De personen, waarin de boehake zich incarneeren, de priesters dus, worden gewoonlijk ook boehake genoemd, minder bolia; met dit laatste woord duidt men meestal het werk aan, dat de priester doet, mobolia. Er zijn heel veel meer mannen dan vrouwen, die door geesten bezield worden, en daarom zal ik verder alleen van Priesters spreken. In Baloa en Tamboenan waren op het tijdstip, dat men tot het Christendom overging, slechts drie vrouwen priester, tegenover een aantal mannelijke priesters, dat men mij niet wist op te geven.

Wanneer de boehake in den priester is gevaren, is hij sokoe'on ,bezield"; dit moet onderscheiden worden van sawe'on, dat „bezeten” beteekent, en gezegd wordt van iemand, die buiten zichzelf is geraakt en als een razende om zich heen slaat; het is wel voorgekomen dat zoo'n bezetene in dien toestand anderen doodde.

Men leert niet om priester te worden, maar een boehake of djin kiest een persoon uit, met wien hij in geregeld contact wil komen; men noemt dit ,vriendschap sluiten” van een geest met een mensch. Zoo'n persoon keert bijvoorbeeld terug van een bezoek aan een ander dorp, of hij heeft iets van den akker gehaald, en dan wordt hij thuis gekomen, plotseling ziek. In zijn ziekte praat hij van allerlei vreemde dingen, waarvan hij zich later niets herinnert. Wanneer de ziekte aanhoudt, en de boehake zijn medium dreigt ten ondergang te brengen, wordt een hoofdpriester geroepen. Zoo iemand draagt den naam van sosolan; hij is van alles op de hoogte wat er in de geestenwereld gebeurt. Deze man treedt dan in contact met den bochake, die den nieuweling heeft ziek gemaakt, en weet hem te bewegen die persoon voorloopig te verlaten, waarna de geest later op een kalmer manier tot zijn medium weerkeert. Mocht die mensch

1) Op fig. 133 van Kaudern's I Celebes obygder II, zien we eenige oliboeboes en later te noemen kabila (mandjes van orchidee-stengel gevlochten) aan het dakgebint opgehangen. Wat daar onder $\mathrm{c}$ staat aangegeven als offerplaats voor Manja, is een malige-lige. Den geest Manja wist niemand, wien ik er in Tamboenan naar vroeg, thuis te brengen. 
weigeren den geest in zich te ontvangen en als zijn medium op te treden, dan zou de borhake of djin terugkeeren en hem dooden.

Een priester mag een aantal dingen niet eten, en daaruit vloeit voort, dat de leden van zijn gezin zich eveneens daarvan hebben te onthouden, omdat de potten anders met die spijzen besmet zouden worden. Die verboden spijzen zijn: lobian (Mal. laboe, Lagenaria vulgaris), kosi (Mal. keladi, Colocasia antiquorum), likong (Mal. pakoe, een soort eetbare varen),hongohoet (een groente, die ik niet nader weet te definieeren; ze vertoont veel overeenkomst met de ianggoeloeng (Poso: longoeroe, Hibiscus Manihot), en slangenvleesch. Wanneer de priester zich niet streng hieraan houdt, wordt hij ziek.

Het loon dat de priester krijgt, hangt af van het werk, dat hij heeft gedaan. Heeft de boehake door zijn mond alleen een advies gegeven, hoe men met een zieke heeft te handelen in verband met de oorzaak van de krankheid, dan ontvangt de priester alleen wat sirih-pinang, 1 of 2 aarden borden, en de pooten van het hoen, dat geslacht wordt voor den onvermijdelijk bij zulk een gelegenheid aan te richten maaltijd. Verstrekt de priester aan den zieke ook medicijn, beblaast hij het lichaam van den kranke, betast hij diens buik, of begiet hij den patient met levenskrachtig gemaakt water, dan krijgt hij meer : gepelde rijst en een lap ongebleekt of rood katoen (balasoe en kasaedja).

Wanneer er een zieke is voor wien men den priester wil laten komen, stuurt men hem sirih-pinang met de boodschap er bij, dat zijn hulp wordt ingeroepen. De priester begeeft zich dan naar de woning waar hij is ontboden. Hij gaat in zijn dagelijksche kleeding daarheen, maar hij zorgt dat hij een ui en gember (halia) bij zich heeft; van Dracaena-blad, waarmee overigens de priesters en priesteressen bij nagenoeg alle stammen op Midden Celebes werken, maakt hij geen gebruik. De priester doet zijn werk alleen wanneer de duisternis gevallen is. Als hij bij den zieke gekomen is, zet hij zich kalm naast dezen neer, en kauwt rustig zijn sirihpruim. Heeft dit een poosje zoo geduurd, dan legt de priester een heele pinangnoot vóór zich neer, brandt er wierook (kamangian) bij, legt een ui tegen zijn voorhoofd, waarbij hij om hulp aan de geesten vraagt; plukt de ui uit elkaar, ruikt er herhaaldelijk aan, geeuwt (oemoa), en dan is de geest in hem gekomen. $\mathrm{Nu}$ spreekt de geest zingende door den bolian, vertelt wat de oorzaak is van de ziekte. „Waarom hebt ge ook cassave uitgegraven, terwijl het regende en de zon scheen?” „Waarom 
hebt ge een gemsbuffel gevangen onder belofte, dat ge dan een feest zoudt geven, en ge hebt 't niet gedaan ?" Met dergelijke vragen, geeft de geest tevens te kennen aan welke oorzaak de ziekte moet worden toegeschreven.

Wanneer de geest zegt, dat er niets aan te doen is, dat de kranke moet sterven, dan sterft hij ook. Maar wanneer de geest zegt, dat de verwanten van den zieke den volgenden dag een hoen moeten siachten, dat ze op een offerstelling (talaian) moeten offeren, dan zal hij beter worden. Heel vaak is het de eene of andere gelofte die men heeft afgelegd, maar niet gehouden, wat de menschen ziek maakt.

Meermalen wijst de geest ook een bepaald persoon aan, die den patient medicijn zal geven om beter te worden. Personen die verstand hebben van allerlei kruiden, heeten sando. Ze worden buiten den priester om geroepen; vaak probeert men het eerst met een sando, voordat men den priester roept.

De taal, die de priester gebruikt, verschilt van de dagelijksche. Mijn zegsman Jacob meende, dat het Banggaisch is. Maar het aantal woorden dat de priester bij zijn werk gebruikt, is zóó gering, dat allen die woorden kennen, en de beteekenis er van weten. Er zijn ook priesters die de omgangstaal, salocan, spreken. Wanneer de geest weg wil gaan, geeft hij dit te kennen. Hij zegt dan: Banggai'o! geeuwt weer, en zwijgt dan ten teeken, dat de geest uit hem is gevaren. Vele priesters sluiten onder het bezield zijn de oogen, maar ze bedekken nimmer het hoofd. Nooit heb ik vernomen, dat de priester onder zijn werk zou dansen.

Een voornaam onderdeel van de werkzaamheid van den priester bestaat in het terugbrengen van de levenskracht des menschen (de santoeoe, de semangat der Maleiers), wanneer deze door den eenen of anderen geest is geroofd, of ergens is achtergebleven. Deze laatste soort geesten of setan verblijven in rivieren of aan steile onbegroeide rotswanden, keles geheeten. Als de geest, die in den priester is gevaren, heeft te kennen gegeven, dat de ziekte een gevolg is van de omstandigheid, dat de levenskracht van den patient door den setan van die en die plek is geroofd, gaat men op die plaats een offer brengen. Daartoe neemt men een bamboestaak, die veel takjes heeft; deze ontdoet men van de bladeren; zulk een staak, die tot offerstok moet dienen, heet pompalati. Aan de takken er van hangt men: sole (Coix lacryma Jobi) die als kralen dienst doen; suikerriet, pisang, gepelde rijst, sirih, pinang en allerlei gekleurde lapjes. Aan den voet van dezen bamboe, die in den grond wordt gestoken, is een offer- 
tafeltje (talaian) opgericht, en daarop legt men: gekookte rijst, sirih-pinang, tabak, palmwijn, een hakmes, een speer en een kris, alle uit hout gesneden. Bij deze gelegenheid wordt geen poppetje, nggaling, gebruikt, waarover later meer. Aan het strand gebruikt men wel zoo'n poppetje, waarvoor men zelfs een klein huisje (goesali) maakt.

Is alles gereed dan spreekt de priester terwijl hij den offerstaak vasthoudt : „O gij die op dien rotswand (keles) woont, kom hier en neem onze geschenken in ontvangst, die wij nu geven in de plaats van ons kind, welks levensgeest gij genomen hebt; want ons kind willen we niet aan u afstaan." Wanneer dan een vlinder, een vlieg of een ander gevleugeld insekt zich op den offerstaak of het offertafeltje neerzet, ziet men in dit diertje den setan, die aan de uitnoodiging gehoor geeft, en daarmee tevens aantoont, dat hij den levensgeest teruggeeft. De priester begint dan hevig te trillen, en met hem de bamboe dien hij vasthoudt. Is het een zwarte vlinder, die zich op het offer heeft neergezet, dan is men overtuigd, dat men met een bizonder machtigen setan te doen heeft. Vlinders van andere kleur beduiden de minder aanzienlijke geesten.

Wanneer iemand van het zeestrand is teruggekeerd, en hij wordt ziek, dan is men er zeker van, dat een geest van de zee in hem is gekomen, en hem krank heeft gemaakt. Dan maakt de priester van den bladsteel van de sago een rechthoekig raam, op dezelfde wijze als men een aga-agalan maakt, waarop het eten voor de gasten wordt opgediend (boven reeds beschreven). Moet zoo'n voorwerp dienen om er den geest een offer op aan te bieden, dan heet het pongatohi. Dit raam is aan den onderkant versierd met jong arenblad, en bovenop zijn in den bladsteel kippeveeren gestoken. De ruimte binnen in het raam is met een stuk rood katoen overdekt, en daarop ligt het offer: allerlei etenswaren en sirih-pinang. De lieden van de Lingketeng-clan leggen er ook nog een pisangbloem (poesoe) op, dat waarschijnlijk is bedoeld als een plaatsvervanger voor den zieke, maar zelf weet men het niet meer waarvoor het dient. Is alles gereed, dan houdt de priester deze pongatohi boven het hoofd van den zieke, en verzoekt den setan van de zee den patient te verlaten, en op het offertoestel over te stappen. Als de zieke dan begint te trillen, is dit een bewijs, dat de setan aan het verzoek heeft voldaan. Dan loopt de priester altijd met het offerstel in de handen langzaam achteruit, al door roepende: „Kom! kom! dit is uw weg”. Op deze wijze loopt hij door het heele dorp, en aan het eind van de kampong gekomen, hangt 
hij het voorwerp ergens aan een boom op. De zieke moet dan herstellen.

Weer een andere voorname tak van de werkzaamheid van den priester is het miloeloes. In het dagelijksche leven gebeuren dingen, waarvan men gelooft, dat een magische werking op den mensch uitgaat, die daarvan nadeel aan zijn gezondheid ondervindt. Enkele van deze gevallen heb ik al genoemd, bijvoorbeeld als een omineuze vogel een huis binnenvliegt, moet hiervan het gevolg zijn, dat de eigenaar er van sterft. Het miloeloes nu heeft ten doel den verderf aanbrengenden invloed van zoo'n gebeurtenis van den bedreigden persoon af te halen, hem van de smetstof te ontdoen. Zoo'n handeling heet piloeloesan of polias, die in de uitvoering van elkaar verschillen.

Voor het piloeloesan maakt de priester een ring van een bepaalde rotansoort. Deze ring wordt omwikkeld met bladeren van verschillende planten, waaraan men om haar eigenschappen of om haar naam bizondere kracht toeschrijft, zooals tabang (Draecena), bomban, tawas, bakolo, pepas, kaoe goein, teatang. Deze ring haalt de priester over de bedreigde persoon heen, over het hoofd, langs het lichaam tot aan de voeten, waarna de behandelde er uit treedt. Zoo doet hij viermaal, en onder dit werk spreekt hij voortdurend, zeggende, dat alle kwaad, dat door de bewuste gebeurtenis kan worden veroorzaakt, nu weggenomen is. Soms worden alle leden van een gezin op deze wijze behandeld.

Nadat de ring viermaal over allen is heengegaan, maakt de priester hem open, en hakt den rotan in 4 stukken. Wanneer het gebeurt dat de rotan niet met één slag van het hakmes wordt doorgekapt, zal één van de daarmee behandelde menschen sterven. De vier stukken van den rotan worden in een bak met water gelegd, en met dit water wascht elk der behandelden zich het gelaat. Tenslotte legt de priester de vier stukken in een waterplas of in de rivier, zet er een paar steenen op, opdat ze goed onder water zullen blijven, en gaat dan weer naar het huis van dengeen, dien hij op deze wijze heeft gecureerd. Wanneer hij daar een poos heeft gezeten, sirih heeft gepruimd en gerookt, komt de bochake of de djin in hem, en dan deelt deze door zijn mond aan de aanwezigen mede, of iemand aan de smetstof, die hij heeft afgestreken, zal sterven of niet. In bezeten toestand wrijft hij ieder met een ui, die daarna in de deuropening van het huis wordt opgehangen. Wanneer de geest den priester heeft verlaten, heeft er een maaltijd plaats.

Een andere wijze om een slecht werkenden invloed van een persoon 
af te nemen is het polias. Dit kan ook door iemand worden gedaan, die geen priester is. De priester neemt dan een takje van drie planten, waarvan men mij de namen niet kon noemen, omdat zich onder zijn zegslieden niemand bevond, die het polias kon uitvoeren. Van deze takjes snijdt hij 7 stukjes af, en pruimt die. Vervolgens wendt hij het gelaat naar het Westen, houdt een hakmes voor den mond, en spuwt het pruimsel. Het hakmes met het pruimsel er op zwaait hij naar het Westen toe en zegt: Mompiakon djoiloe Ampana, „dit moge de lieden van Ampana treffen". Zoo doet hij zevenmaal.

Vervolgens legt hij het hakmes om beurten op de hoofden van allen, die hij van de gevaarlijke smetstof moet ontdoen, en zegt daarbij: Soemo besak oemoen, ,als ijzer (zoo langdurig) zal uw leven zijn". Dan neemt hij het pruimsel van het hakmes af, en strijkt daarmee over ieders hoofd. Is dit afgeloopen, dan maakt de priester zich 7 kleine bamboe kokertjes, die hij alle met water vult, en dan tot een bos samenbindt. Hiermee plaatst hij zich tegenover de te behandelen personen. Terwijl hij nu de kokertjes in de hoogte houdt, slaat hij er met het hakmes tegen, zoodat het water dat er zich in bevindt, uit de bamboetjes spat op de vóór hem zittende menschen. Onder dit werk spreekt hij: Natawasa ambclo. Liasakon na nokon, liasakon na nobana; liasakon na noajooe. Inatazvas, timbali memboeoen. ,Alle voorteekenen (waarvan een schadelijke werking op den mensch uitgaat) zijn krachteloos gemaakt. Dat ze (niemand) moge treffen; dat ze niemand kwaad moge doen; dat (de kracht van de voorteekenen) zich niet moge verspreiden (en anderen treffen). Ze zijn krachteloos gemaakt, en wind geworden (d.i. ze zijn als de wind weggegaan)". Hiermede is de zaak afgedaan.

Een bizondere rol speelt de priester bij sterfgevallen. Het gebeurt vaak, dat een kind ziek wordt, en dan geeft de boehake door den mond van den priester te kennen, dat de reden van de krankheid gelegen is in de omstandigheid, dat het graf van de overleden moeder of van den vader niet is schoongemaakt. Natuurlijk wordt dit verzuim dan dadelijk hersteld.

Of het kan gebeuren, dat iemand zóó bedroefd is over het verlies van een kind, dat hij of zij er niet aan denkt het offer voor den bochake-geest in de oliboeboes (offerkorf) te vernieuwen; dan wordt die persoon ziek gemaakt door de ziel van het gestorven kind, die blijkbaar macht over den levende krijgt, omdat de bochake niet „levend" (krachtig) wordt gehouden door offers. Het is weer de priester die dit in bezielden toestand mededeelt. Dan begiet hij het 
heele huis met water, waarbij hij met een bos bladeren tegen de stijlen en de wanden van het huis slaat om de doodenziel (tominoeat) die de krankheid heeft veroorzaakt weg te jagen. De patient zelf wordt ook met water besprenkeld, en met de bladeren beklopt. De bos bladeren wordt ten slotte vóór in het portaal van het huis gestoken. Deze heele handeling heet mombohobas.

Wanneer men van het begraven van een lijk thuis gekomen is, heeft de priester weer een en ander te doen. Hij gaat na afloop van den maaltijd naar beneden met een Dracaena-tak (tabang) in de eene, en een bakje (soehoe) van palmblad in de andere hand. Aan dat bakje is een kippeveer gestoken, en het is gevuld met water. De priester loopt het pad op naar het graf, en halfweg gekomen zet hij het bakje met water op den grond. Daarbij wordt ook een leege draagmand (basoeng) geplaatst, en een man of jongen, die geen ouders meer heeft, verstopt zich in de struiken in de nabijheid van die plek. Allen die aan de begrafenis hebben deelgenomen, volgen den priester, en hebben de bladeren, waarvan ze hebben gegeten, bij zich; deze worden op een hoop midden op het pad gelegd. Ook de weduwnaar is meegegaan; hij heeft het hoofd bedekt met een lap wit katoen. De priester loopt spiedende rond, tot hij zegt: Daar komt de setan; hij wil de levenskracht (santoeoe) van N. N. grijpen". Dan holt de priester naar voren, maakt allerlei onverwachte wendingen links en rechts, alsof hij iets achterna loopt, en doet dan plotseling een greep in het gras, waarvan hij wat afrukt.

Hij vertelt, dat het hem gelukt is de levenskracht van N. N. nog juist bijtijds te grijpen, voordat de setan deze mee kon nemen naar zijn voor menschen onbereikbare woonplaats. Men beweert, dat ouden van dagen, die geen priester zijn, ook in staat zijn den setan te zien, wanneer ze zich de oogen wasschen met het water uit het bakje. Ten slotte steekt de priester met den Dracaenatak een gat in het bakje van pandanblad, zoodat het water daaruit wegvloeit. Op datzelfde oogenblik geeft de verborgen persoon een hevigen slag op de leege draagmand; daarvan schrikt de setan geweldig, en maakt zich uit de voeten. Het water in het bakje moet mede dienen om een scheidingsmuur op te richten tusschen mensch en geest; dit water kan de laatste niet overgaan om den eerste kwaad te doen. Deze heele handeling noemt men molaa. Na afloop er van keert men naar het sterfhuis terug.

De rol die de priester bij den landbouw vervult, is van geringe beteekenis. Het eenige wat hij doet is bij het begin van het bewerken 
van den akker vaststellen of de landbouwers gedurende het jaar ziek zullen worden, dan wel of zij in gezondheid de vruchten van hun werk zullen plukken. Daartoe brengt men hem een kluitje aarde van het veld, dat men gaat bewerken, en dan vertelt de geest, die den priester bezielt, wat van de toekomst is te verwachten.

Bij huwelijk, bij bevalling en bij naamgeving komt de priester ook te pas, maar hetgeen hij daar doet, zal ik later ter plaatse mededeelen.

\section{Andere Geesten.}

Tot nu toe hebben wij alleen gesproken over bochake en djin, geesten, die den menschen welgezind zijn, en over minder welwillende wezens, die algemeen met den naam van setan worden aangeduid. Deze heeten ook wel mohaki, wat ,ziek zijn” beteekent. Men treft ze overal aan, en elke handeling van menschen, die hen niet aanstaat, wordt met ziekte van den schuldige gestraft.

Dan heeft men nog montailowo, of montailobo, wezens die voortdurend heen en weer gaan tusschen het bovenland en het zeestrand. Een andere naam voor hen is baio. Men zegt, dat ze als apen zijn, die op den rug van hun handen en voeten loopen, zoodat de indrukken van hun vingers en teenen wijzen naar de plaats, waar ze vandaan komen. Ze hebben maar één tand in den mond. Wanneer men zoo'n wezen in de wildernis ziet, moet men gauw wegloopen en naar huis gaan, anders zou men ziek worden. Ze verwonden zich wel eens aan scherpe bamboes, die de menschen in den grond steken om wild te bemachtigen, en dan sterven ze. Hun voornaamste woonplaats is op den berg Hehede boven Toimaa. Ze laten menschen in de wildernis verdwalen, zoodat ze daarin omkomen.

Een andere soort geesten zijn de lambeboeang, die onder den grond wonen, maar op aarde komen, en de menschen ziek maken. Eens kwam zoo'n lambeboeang in het huis van zekeren Langkoeadong, waar hij al het getookte vleesch van gemsbuffels opat, waarria hij ging liggen slapen. Toen Langkoeadong thuisgekomen den geest zag slapen, smeerde hij den vloer met vogellijm in, zoodat de lange haren van den geest daaraan vastkleefden. Toen maakte hij zijn speer gloeiend in het vuur, en stak die den geest in het lijf. Met een schreeuw sprong deze op, en rukte den vloer waaraan zijn haren kleefden, los, en daarmee ging hij op den loop. Langkoeadong volgde hem, en zag den lambeboeang in een gat in de aarde verdwijnen. Hij volgde hem daarin en kwam zoodoende in het dorp van de aardgeesten. Daar 
vond hij vele van die geesten geschaard om het ziekbed van hun Hoofd, maar niemand kon de oorzaak ontdekken van zijn ziekte. Langkoeadong begreep, dat de geest krank was door het lemmet van zijn speer, dat in diens lijf was blijven zitten. Hij bood zich aan om den vorst der lambeboeang te genezen. Toen hij tot hem was toegelaten, trok hij het lemmet uit diens lijf, ten gevolge waarvan de vorst stierf. Langkoeadong vluchtte met zijn speer, achtervolgd door een groote schare geesten. Bij het gat, dat naar de oppervlakte van de aarde voerde gekomen, stopte hij dit achter zich dicht, zoodat de geesten hun vervolging moesten opgeven ${ }^{1}$ ). Deze lambeboeang overvallen de menschen nu en dan als ze aan de bron water halen of in het bosch brandhout verzamelen.

De pas genoemde géesten zijn weer andete dan de toempoe noe tano ,eigenaars van den grond”. Met dezen houdt men rekening, wanneer men akkers aanlegt. Ze worden voor heel nijdig gehouden, geesten, die om een kleinigheid de menschen ziek maken. We zullen deze aardgeesten meermalen tegenkomen, wanneer we over den landbouw spreken.

De voornaamste en misschien meest oorspronkelijke geesten der Loinangs dragen den naam van pilogot. Dit zijn de zielen van de lang geleden gestorven stamvaders. Elke familie in uitgebreiden zin heeft zijn pilogot of stamvader, en aangezien elk dorp door één familie in uitgebreiden zin wordt bewoond, heeft ieder dorp zijn pilogot. Alleen de afstammelingen van dezen oervader kunnen hem vereeren. Voor menschen die niet tot zijn nakomelingschap behooren, is hij niets. Van den pilogot verwacht men alle mogelijke zegeningen. Maar hij is ook degeen, die streng waakt tegen alle tekortkomingen in de adat. Zijn macht en zijn ongenoegen openbaren zich in rampen, die een familie overkomen. Ieder zijner nakomelingen, die door hem vervloekt wordt, moet sterven.

Wanneer de pilogot wordt aangeroepen, wordt zijn naam gewoonlijk verbonden met balakat, het Arabische berrkat, welk woord, zooals ik al opmerkte, waarschijnlijk via Ternate onder de Loinangs is gekomen. Met dit balakat wordt bedoeld de zegen, die langs magischen weg uitstroomt van de Sultans van Banggai en Ternate.

1) We herkennen in dit verhaal een variant van het overal in Indonesië voorkomende verhaal, hoe een mensch een meestal van een ander geleend voorwerp uit de onderwereld terugbrengt. Men zie hiervoor Dr. P. Voorhoeve, Overzicht van de Volksverhalen der Bataks, onder no. 110, de Twist tusschen Si Sangmaima en Datu Dalu (blz. 125-128). 
Vooral de pilogot van de clan der Lingketeng-menschen zijn zeer gevreesd. Twee van hen zijn de voornaamsten. Voor het Lingketengsche is dit de ziel van Kamboa, een der eerste Hoofden van dit volk. Voor het Pinapoeansche is het de ziel van Mogoembali, dien we in het historisch overzicht hebben ontmoet. Men durft den naam van den pilogot niet uitspreken, tenzij men er een hoen bij slacht, om hem daarvan te offeren. Bij de Baloa-clan is de vrees voor pilogot al even groot als bij de andere lieden, maar de vereering van hem gaat veel eenvoudiger toe dan bij de Lingketeng-menschen.

De naam pilogot wordt weinig gebruikt, en in de gevallen, waarin de leden van de Lingketeng-clan van pilogot spreken, noemen de Baloa-menschen den geest boehake. Dit komt nog duidelijker uit, wanneer we straks over het feest spreken, waarbij de pilogot in het bizonder verbonden is, namelijk het monsale.

Met den pilogot bij de Lingketeng-clan hebben de priesters niets uit te staan. De bemiddeling tusschen den pilogot en zijne nakomelingen heeft namelijk plaats door het Hoofd van de familie waarvan de pilogot de stamvader is. In het Lingketengsche is dit de daka'njo (tegenwoordig kapitan), in 't Pinapoeansche de tonggol (tegenwoordig kapala) van die plaats. Verder zijn er meer pilogot, wier aanzien niet groot is, omdat het aantal lieden, dat hen vereert, niet groot is.

De pilogot houdt verblijf in de woning van het Hoofd der familie. Voor hem staat in het slaapvertrek van den heer des huizes een houten bord (doelang), waarop een van orchideeën-stengels gevlochten sirihdoos (kabila) staat. De orchidee van welker bladscheeden het dikke gele uiteinde voor het maken van deze doozen wordt gebruikt heet mintoe (Poso: wintoe, Dendrobium utile). Deze doozen worden uitsluitend voor den eeredienst van pilogot gebruikt. Wanneer enkele personen zoo'n sirihdoos ook voor dagelijksch gebruik er op na houden, wordt ze toch alleen aan zeer voorname personen voorgezet. Die doos moet altijd goed voorzien zijn van pruim-ingrediënten, die worden vernieuwd als ze wat oud zijn geworden.

Wanneer de piligot iets aan zijne nakomelingen wil te kennen geven, daalt hij in het familiehoofd neer. Dan breekt dezen het zweet uit; hij voelt zich duizelig worden; hij ziet alles dubbel en als door een waas, en begint dan te spreken; maar hij weet niet wat hij zegt; dit hoort hij later van de omstanders. De taal waarin de pilogot spreekt is de dagelijksche omgangstaal. Wanneer er kwestie was van ten oorlog te gaan, blies het stamhoofd in dezen toestand op de gemher, die den strijders te eten werd gegeven om dapper te zijn. De 
pilogot geeft ook vaak uitsluitsel over ziekte, waarmee het dorp is bezocht; hij geeft de oorzaak daarvan op, en de wijze waarop men haar kan bestrijden. Ten opzichte van voorname lieden onder zijn nakomelingschap deelt hij vaak mee, of ze van hun krankheid zullen herstellen of niet.

Van den pilogot verwacht men, dat hij de rijst zal doen gelukken. Wanneer van de nieuwe rijst zal worden gegeten, wordt eerst een kom met gepelde rijst op de verblijfplaats van den pilogot neergezet, en daarna pas mag men er van koken en eten. In kleine particuliere aangelegenheden mengt men den pilogot niet, maar wanneer het moeilijkheden of geschillen van algemeenen aard aangaat, waarin de heele familie betrokken is, dekt de tusschenpersoon (het Hoofd) het houten boord, waarop de pilogot woont, met wit katoen, en legt daarop sirih pinang en een bakje met palmwijn. Met het gelaat naar de deuropening gekeerd roept de vertegenwoordiger van den pilogot den oervader aan, en vraagt hem om zijn hulp in de gerezen moeilijkheden te verleenen. Daarna wordt de woonplaats van den voorouder weer in de slaapkamer van den heer des huizes weggezet, en niemand mag er aan raken.

Eenmaal 's jaars werd (wordt?) er bij de lieden van den Lingketeng-clan een groot sale-feest gevierd, waaraan alle leden der groote familie deelnamen. Dit feest, monsale, had plaats ter eere van den pilogot. Het woord sale zal wel hetzelfde zijn als dat wat wij uit het Bare'e kennen, en dat de beteekenis heeft van ,deelnemen aan een feest, plechtigheid of werkzaamheid". Ik moet dit sale-feest voor de beide afdeelingen van de Lingketeng-clan (Lingketeng en Pinapoean) en voor de Baloa-clan afzonderlijk behandelen, aangezien tusschen die plechtigheden vrij veel verschil bestaat.

Een algemeene trek van het monsale is, dat het gevierd wordt na afloop van den rijstoogst, wat eigenlijk vanzelf spreekt, omdat het gelukken van den oogst aan den zegen van den pilogot wordt toegeschreven, en omdat men dan genoeg rijst heeft om feest te kunnen vieren. Wanneer de dag voor het monsale in het Pinapoeansche is aangebroken, wordt het graf van Mogoembali met jonge arenbladeren versierd. Een gemsbuffel en een groot aantal hoenders worden gereed gehouden om op het feest te worden geslacht. Aan het hoofdeneind van het graf wordt een vloertje van bamboelatten gebouwd, waarop later het of fer aan pilogot zal worden gelegd. Wanneer men met alles gereed is, wordt op gongs geslagen, en dan komen allen die aan de vereering van den pilogot willen deelnemen, bijeen. 
Dit gebeurt ongeveer om 4 uur 's namiddags, en om 5 uur heeft de gemeenschappelijke maaltijd plaats. Op het reeds genoemde vloertje worden 4 Dracaenabladeren in een vierkant gelegd, en daarop wordt geelgemaakte rijst gestrooid. Op een bord tusschen de Dracaenabladeren in liggen rauwe maiskorrels (osale), 5 sirih-vruchten, 5 pinangnoten, 4 sigaretten en 4 ongekookte eieren, terwijl een wit hoen wordt vastgehouden, dat men na de aanbieding van het offer los laat. Iemand die niet tot de nakomelingschap van den pilogot behoort, mag het hoen nemen en slachten; men gelooft, dat in het dorp, waarheen het hoen liep, een ziekte zou uitbreken. Het Hoofd (tonggol) zit op het vloertje bij het offer, en de menigte schaart er zich om heen; de voornaamste lieden zitten vooraan, en dezen houden het vloertje met arenbladeren (taliti) vast. Dan roept de tonggol den pilogot aan, en vraagt hem om gezondheid, rijkdom, geluk voor al zijne nakomelingen. $\mathrm{Na}$ afloop van den maaltijd keert men naar huis terug.

Wanneer in het Lingketengsche monsale plaats zou hebben, werd hiervan kennis gegeven aan alle leden van de groote familie. Van alle kanten kwam men dan naar Lingketeng toe met trommen en gongs, en vele mannen hadden de hamboet, een speer met haar versierd (hamboet is het Mal. ramboet ,hoofdhaar”), bij zich om daarmee krijgsdansen uit te voeren. Om een uur of 11 gaat men onder leiding van het Hoofd (daka'njo of kapitan) naar de graven van Kamboe en Besi, wier beenderen, zooals ị al heb verteld in een paar kisten boven den grond staan. Men gaat dan om de kist zitten en spreekt het volgende: Imangan mae aia, balakat $i$ Tongkoi, balakat $i$ Babinto, balakat $i$ Kamboa. Mihi-mihidje be'i mae kawa-kawasa, liasakon panjakit, be'i meoemoen-oemoen, dat nota'oep oe Komponia napohahopnjo hasin. „Komt hier pinangpruimen, kracht van Tongkoi, kracht van Babinto, kracht van Kamboa. Geeft ons welvaart in het vervolg, laat er geen ziekte komen, maar geeft, dat we een lang leven hebben, opdat door het Gouvernement verkregen worde wat er aan wordt opgebracht, belasting”. Want, voegt men er bij, als de menschen dood gaan, kunnen ze geen belasting meer voor het Gouvernement zoeken. Bij deze gelegenheid wordt niets op de kisten gelegd. Nadat de pilogot is aangeroepen, gaat men naar huis terug, waar in den namiddag een groote maaltijd wordt gehouden. Alles duurt slechts één dag.

Ik moest dit alles in den verleden tijd vertellen, omdat de menschen van Lingketeng tot het Christendom zijn overgegaan. Maar ik heb 
reden te gelooven, dat velen hun geloof in den pilogot nog niet hebben opgegeven. Het distriktshoofd zelf althans voert de bedoelde plechtigheid nog elk jaar met een aantal getrouwen uit, al is hij gedoopt. „Ik zou niet weten wat er van ons land en ons volk moest worden, als ik het monsale naliet,” zei hij mij. „Want wanneer pilogot zijn zegen niet meer gaf, zouden alle menschen in korten tijd omkomen".

Behalve het jaarlijksche monsale tot heil van den stam na afloop van den rijstoogst, houdt men nog samenkomsten omi de hulp van den pilogot in te roepen bij bizondere gelegenheden. Zoo wanneer de oogst dreigt te mislukken door te veel regen of langdurige droogte. Dan wordt het deksel van de kist, waarin de beenderen van Kamboa zijn, afgelicht, en de beenderen worden met water afgewasschen als regen gewenscht is; ze worden met olie ingewreven, als men droogte wil hebben. ,Zoodra dit was gedaan," vertelde men mij, ,volgde regen of droogte". Ook wanneer er een ziekte in aantocht was, kwam men bij het graf van den pilogot te zamen om zijn hulp af te smeeken en de ziekte af te wenden.

Het Baloa-volk heeft evenzeer zijn stam-pilogot, die in het huis van het Hoofd woont op een houten schaal, waarop een sirihdoos van orchideeën (kabila). Wanneer men bijeenkomt om den pilogot aan te roepen, wordt geen maaltijd gehouden; men verzamelt zich alleen in de woning van het Hoofd, die den stamvader aanroept en om hulp vraagt, bij welke gelegenheid door de aanwezigen alleen palmwijn wordt gedronken. Zoo'n samenkomst had gewoonlijk slechts plaats, wanneer een besmettelijke ziekte in aantocht was. Na afloop daarvan mocht niemand zich gedurende een aantal dagen buiten de nederzetting begeven; men moest zich in alle opzichten stil houden.

Heeft zich bij de Lingketeng-clan de dienst van den pilogot blijkbaar om den stamvader geconcentreerd, of liever nog om den stamvader van de Hoofden, bij de Baloa-menschen is dit niet het geval: hier kent men nog de vereering van den stamvader van ieder gezin, maar deze heet dan niet pilogot, maar wordt boehake genoemd. Bij de Baloa-menschen wordt dus nog de ziel van den voorvader met de boehake vereenzelvigd, dus met de geesten die in den priester varen, en hem helpen om zieken te genezen. Het is daarom niet te verwonderen, dat bij de vereering van de stamouders der Baloa-menschen de priester wèl een rol speelt, zooals we dadelijk zullen zien. Wij zien dus, dat de Baloa-menschen in dit opzicht in een oorspronkelijker stadium verkeeren dan hetgeen we over pilogot-vereering bij de 
Lingketeng-menschen vinden, welke laatste vereering blijkbaar ontstaan is onder invloed van het hoofdengeslacht, dat onder de Baloamenschen geen voet heeft kunnen vatten. Het algemeene monsale, dat bij de Baloa-menschen na den rijstoogst wordt gevierd, draagt dan ook een ander karakter. Elk gezin namelijk viert dit feest voor zichzelf, waarbij de leden van het eene gezin als gasten bij het andere komen. Het monsale is hier dus een reeks van kleine feesten, die achter elkaar worden gehouden, en het duurde volgens mijn zegsman Jakob soms drie maanden, voordat elk huis zijn beurt had gehad. De Baloa-menschen die geheel democratisch leefden, kenden niet de macht van een vorst, die alles om zijn persoon concentreerde, zooals dit het geval was bij de Lingketeng-clan.

Een andere benaming dan monsale voor dit feest was bij de Baloamenschen mombaoe boehake „boehake-geesten maken”. Een hoofdpriester maakt dan twee houten borden als offertafels gereed door er een vlechtwerk van uiteengerafeld kokosblad op te leggen, aan de vier hoeken waarvan geurige kruiden zijn vastgemaakt; verder bloemen, sirih-pinang, tabak en andere dingen zijn neergelegd. Op deze houten borden wordt een aarden schotel met gekookte rijst gezet, en daarnaast twee kleinere schoteltjes, een met kippepooten en een met palmwijn. Daarover heen wordt een nieuwe hoofddoek, of een lap van een ander soort katoen uitgespreid, en daarop vindt de sirihdoos (kabila) van orchideeën een plaats; dit is de doos, waarin steeds pruim-ingrediënten aan den stamvader worden aangeboden. Verder worden er twee offerkorven (oliboeboes) gemaakt, waarin ongeveer hetzelfde offer wordt geplaatst. De beide houten borden met de sirihdoos er bovenop zijn bestemd voor den vader van den huisheer en voor dien van de huismoeder. De offerkorven zijn bestemd voor de moeders van huisheer en huisvrouw. Zoo drukt men het ten minste uit, maar de bedoeling is waarschijnlijk het stamouderpaar van den huisheer en dat van de huisvrouw te vereeren.

Wanneer al deze dingen gereed zijn vangt de hoofdpriester aan al die geesten (bochake) te vragen alle ziekte van het huis af te wenden en voorspoed te geven. Daarna zet men zich aan een gemeenschappelijken maaltijd. Is deze afgeloopen, dan heeft er nog een kleine plechtigheid plaats. Aan den middelsten paal van het huis is namelijk een bamboe koker met palmwijn vastgebonden. Deze wordt door den hoofdpriester toegesproken (besproken) om daarin (voor zoo ver ik heb begrepen) kracht of een zegen te doen neerdalen. Hierna wordt de bamboe van den paal losgemaakt, en drinken alle leden van het 
gezin er uit; ook de rijst en de kippekluiven, die op de houten borden en in de offerkorven zijn gelegd, worden door hen opgegeten, waarschijnlijk om op deze wijze den zegen der voorouders deelachtig te worden.

Twee dagen daarna heeft een kleine plechtigheid zonder feestelijkheid plaats, die molapa doelang ,loslaten van de houten borden" heet. Dan worden de sirihdoozen (kabila) voor de stamvaders en de offerkorven (oliboeboes) voor de stammoeders in het dak van de woning opgehangen.

$\mathrm{Om}$ in gemeenschap te komen met den pilogot, ging men op de graven van de stamvaders slapen. Bij dat van Kamboa deed men dit zelden, vertelde men. Op deze wijze trachtte men met den geest een ontmoeting te hebben om van hem tooverkruiden of eenig voorbehoedmiddel machtig te worden. Deze wijze van handelen heet alatapa (Poso: baratapa, een verbastering van het Maleische bertapa, als kluizenaar leven). Zoo iets schijnt echter alleen bij de Lingketeng-clan bekend geweest te zijn.

De ziel van iemand die niet lang geleden gestorven is, heet tominoeat, en deze wordt door de menschen gevreesd. Wanneer ze een harer nabestaanden toespreekt, moet die persoon ziek worden. We hebben gezien dat de levenskracht van den mensch santoeoe heet ${ }^{1}$ ). Deze verwijdert zich nu en dan van haar woning, het lichaam; hijv. in den slaap, en dan droomt die persoon. Als de santoeoe niet tot hem terugkeert, wordt die mensch ziek en sterft. Nu gebeurt het wel eens, dat die santoeoe door een boozen geest, een setan, wordt gegrepen. Dan komt de priester en maakt een poppetje van hout, nggaling geheeten. Hij brengt een offer aan den setan, spreekt dezen toe, en biedt hem het poppetje aan als plaatsvervanger voor den zieke, opdat de setan de levenskracht teruggeve. De priester gaat dan op zoek naar de verloren levenskracht, vangt die op in een doek, en brengt haar daarin naar huis terug. Bij den patient gekomen drukt hij den doek op diens hoofd om zoo de levenskracht weer in 't lichaam terug te brengen.

Maar het kan ook zijn, dat de ziel van een doode (tominoeat) de levenskracht in haar macht heeft gekregen. Dan gaat men op een

1) Dit woord doet denken aan het nabootsen van een klank. In het Pososch is katoeoc-ntoeoe ,,aldoor pang, pang! bons, bons!" Bijvoorbeeld kantoeoentoeoe asoendodonja ,zijn hart (eig. hartskuil) klopte”, van angst, enz. Het is dus mogelijk, dat met santoeoe het kloppen van het bloed in de aderen wordt bedoeld, speciaal de pols.

D1. 86. 
andere wijze te werk, en daarbij behoeft geen priester te helpen. Een van de oudere huisgenooten maakt dan op een bord een offer klaar van gekookte rijst met ei, waarbij ook sirih-pinang wordt gelegd. Dit bord wordt bij het hoofd van den zieke neergezet, en dan zegt men : „Kom eten en pruimen, en maak niet ziek”. Wanneer er dan veel vliegen op het eten afkomen, is dit een bewijs dat het offer is aangenomen, en dan zal de zieke herstellen. Dit voedsel wordt verder door de aanwezigen opgegeten. Men noemt deze handeling mondedesi. Het is hierbij niet duidelijk of de doodeziel wordt geroepen om haar te bewegen levenskracht te geven, dan wel de levenskracht zelf.

Duidelijker is de bedoeling in het volgende: Wanneer iemand bloed opgeeft, zegt men dat het een doodenziel (tominoeat) hiervan de oorzaak is. Dan verzoekt men iemand die dit meer gedaan heeft om de doodenziel te vragen dien mensch niet langer te kwellen. Men legt dan op een koperen schaal (doelang) sirih-pinang en een sigaret, en dan zegt men: Komioe tominoeat, mangan atina: mokopangan monsosop kopi-kopian, sinalao na kami. Pooeahemo atina $i$ pomangan. „Gij doodenziel, pruim dat; als ge gepruimd hebt, rook dan terdege; wij hebben kwaad gedaan (wij zijn schuldig). Verhuis (de ziekte) op de pinangschaal".

Zooals we dus hebben gezien, verleenen de priesters hunne diensten om met de hulp van de boehake en de djin zieken te genezen. Niettegenstaande men meermalen tegenover mij beweerde, dat het werk van een priester altijd met succes bekroond wordt, is men er blijkbaar niet zoo gerust op, of de zieke wel beter zal worden, en daarom wichelt (metahi, montahii, over iets wichelen) men om dit te weten te komen. Bij de Lingketeng-menschen doet men dit algemeen door het meten van den arm met de span der hand, dat badjangan heet. De span van de rechterhand wordt driemaal op den linkerarm afgemeten, nadat vooraf de toppen van de beide middelvingers precies op elkaar zijn gelegd. Wanneer men nu weer naar de hand terugmeet, moet de top van den rechter middelvinger over dien van den linker heen reiken, wil het een gunstig antwoord op de vraag ten opzichte van den zieke wezen. Haalt de top van den rechter middelvinger dien van de linkerhand niet meer, dan is dit een ongunstig teeken.

Men doet iets dergelijks met een speer, badapa: aan een speer of stok wordt gevraagd om aan te wijzen, of een zieke beter zal worden of niet. Dan meet men de speer met den vadem, dien men zoo lang mogelijk maakt, en geeft een teeken tot waar de top van den middelvinger heeft gereikt. Daarna meet men nog eens over: komt de top 
van den middelvinger dan over het aangegeven punt heen, dan beteekent dit een gunstig antwoord. Kan de top van den vinger bij de tweede meting dit punt niet meer halen, dan moet de zieke sterven.

$\mathrm{Nu}$ en dan wichelt men voor een zieke ook met een pinangnoot op dezelfde wijze als dit beschreven is bij de jacht, wanneer men wil weten of de tocht succes zal opleveren of niet.

De genoemde wichelmethoden brengt men ook in praktijk, wanneer men op een handelsreis uitgaat, en men wil weten of de tocht voorspoedig zal verloopen of niet.

Intusschen wordt al dit wichelen alleen gedaan door de lieden van de Lingketeng-clan. Onder de Baloa-menschen verzekerde men mij, dat men slechts één wijze van wichelen (metahi) kent om te zien of een zieke beter zal worden of niet, en wel door middel van maispitten. Men neemt 24 maispitten in de hand; dan blaast men op de gesloten vuist en spreekt de mais toe: „Gij, mais, zult mij vertellen of N. N. beter zal worden; wanneer gij ziet, dat hij zal herstellen, zeg mij dit dan". Daarna opent men de gesloten hand een weinig, zoodat er enkele korrels uitvallen; vervolgens doet men dit nog eens, een eindje verder, en dan weer eens. Wanneer men de eerste maal 4, de tweede maal 3, en de derde maal 1 pit laat vallen, beteekent dit, dat de ziekte een gunstig verloop zal hebben; vallen er eerst 3 , dan 4, dan is het antwoord niet hoopvol. Deze wijze van wichelen wordt bij de Baloa-menschen ook toegepast om na te gaan of een verdacht persoon werkelijk heeft gestolen. Men noemt dan een naam en vraagt aan de maispitten om aan te toonen, of die persoon het inderdaad is. Laat men achtereenvolgens 4, 3, 1 pitten vallen, dan is het antwoord bevestigend, anders niet.

Weerwolven die de lever van hun medemensch opeten, schijnen de Loinangs niet te kennen. Wel personen, die een ander door hun slecht werkenden invloed ziek maken. Het geheimzinnige vergif, dat z.oo'n persoon in eens anders lichaam toovert, heet oesaha of lasoeng (Mal. ratjoen). Op allerwijze kan zoo iets gebeuren. Men wordt bevoorbeeld ziek, kort nadat men iemand te eten of te drinken heeft gegeven; of men voelt zich onwel worden vlak na een gesprek met iemand. Of men heeft iemand een hand gegeven, en voelt daarbij een kleinen steek alsof men door een mier wordt gebeten; de pijn plant zich in het lichaam voort. totdat men bloed opgeeft (ook in den ouden tijd zegt men de gewoonte gehad te hebben elkaar de hand te geven, en dan een zegenwensch uit te spreken; dit heet moita do'a). In weinig dagen kwijnt men weg en men sterft. Gedurende zijne 
ziekte deelt de kranke zijne vermoedens aan de omstanders mede, dat die en die persoon met zwarte kunst omgaat. Het geval wordt aan den tonggol medegedeeld. Wanneer driemaal een dergelijke klacht over dezelfde persoon bij het Hoofd was binnengekomen, gaf hij daarvan kennis aan den daka'njo, die dan een boodschap zond naar den bosanjo te Kintom, met het verzoek om de bewuste persoon te mogen dooden. Zonder uitzondering werd de toestemming altijd gegeven.

Wanneer de beschuldiging in de oogen van anderen niet overtuigend was, of de verdachte had beschermers, dan werd besloten een godsoordeel aan te laten wijzen of die persoon schuldig was of niet. Dit gebeurde altijd door het momanas, dat ik boven al beschreven heb: een pot met water werd dan te vuur gezet; aan de eene zijde er van nam de beschuldigde plaats, aan den anderen kant een der beschuldigers. Wanneer het water aan den kant van den eersten begon te koken, werd zijn schuld bewezen geacht. Begon het te koken aan de zijde van den beschuldiger, dan werd de aanklacht voor valsch gehouden, en dan had die partij een boete te betalen van 25 blok ongebleekt katoen (balasoe). Kookte het water over de heele oppervlakte tegelijk, dan werd er een koperen duit in gedaan. De aanklager moest deze er 't eerst uithalen: vertoonde zijn hand brandwonden, dan werd de anklacht voor valsch gehouden, en moest hij de reeds genoemde boete betalen.

Bleek de aangeklaagde schuldig te zijn en had men de toestemming van den heer te Kintom gekregen, dan werden gewoonlijk lieden uit een andere streek verzocht den gifmenger te komen dooden. De lieden van Lingketeng en Baloa bewezen elkaar wederkeerig dezen dienst. Bij de Baloa-clan ging het op dezelfde wijze toe bij de berechting van zoo'n zaak; alleen besliste daar niet het Hoofd, maar moest de publieke opinie tegen een gifmenger zijn, voordat men er toe kwam hem te laten dooden.

Iemand die door zwarte kunst was ziek gemaakt, werd niet door een priester behandeld, maar door een sando, iemand die verstand heeft van kruiden en medicijnen. Deze snijdt van allerlei planten waarvan hij alleen de namen kent, 7, 9 en 3 stukjes en laat deze samen met gember door den patient pruimen. Ook wordt deze wel met belezen water gewasschen.

Men beweert dat er ook menschen zijn, die zich als een vlam voordoen. Men noemt dit mamboelit. In hoeverre zulke lieden gevaarlijk zijn voor hun omgeving, ben ik niet te weten kunnen komen. Men 
had het vooral over één sterk werkend vergif, dat evenwel alleen door lieden, die dicht bij het zeestrand wonen, kan worden gemaakt. Men heeft daarvoor een kat noodig. Dit dier wordt gedood en het lijk in arenvezels gewikkeld op sagobladscheede gelegd. Na verloop van drie dagen neemt men het lijkwater, dat zich op de bladscheede heeft verzameld; dit doet men in een bamboe koker en vermengt het met allerlei andere dingen, die alleen de beoefenaar van deze zwarte kunst kent. De koker wordt aan den buitenkant van de woning bewaart, opdat de kracht van dit middel de bewoners niet zal aantasten. Wil men iemand vergiftigen, dan doet men ongemerkt iets van dit mengsel op zijn eten. De persoon in kwestie zal dan hevig gaan hoesten, bloed opgeven; hij teert heelemaal uit en sterft. - Hetzelfde effect heeft het, wanneer men de beenderen van een kat droogt en fijn stampt, en van dit poeder een weinig in het voedsel mengt.

Wanneer een ziekte in aantocht is, wordt bij de Lingketengmenschen een bamboestaak genomen, waaraan allerlei etenswaren worden opgehangen. Zoo'n offerstaak heet odoe-odoedoek. Onder geleide van een priester wordt deze bamboe uitgedragen in de richting, vanwaar de menschen door de ziekte bedreigd worden. Daar wordt de staak in den grond geplant, en op den top er van plaatst men een wit hoen. Dan spreekt de priester de naderende krankheid toe, en verzoekt haar de aangeboden staak met etenswaren aan te nemen, en elders heen te gaan. Mocht het hoen later in het dorp terugkeeren, dan verkoopt men het; zelf mag men het niet eten.

Behalve deze algemeen gevolgde methode zijn er heelmeesters (sando), die er hun eigen methode op na houden. Zoo vertelde de meer genoemde Jakob, dat zijn eigen vader een beroemde sando was. Toen eens in Jakobs jonge jaren de pokken het dorp Tamboenan bedreigden, droomde zijn vader, dat hij op een weg liep; hij kwam toen aan een brug, en onder die brug zag hij een enorme pan met vuur. Aan den overkant van den afgrond stortten 4 waterstralen zich op den grond. Toen de man verder liep, kwam hij in een kampong, waar men bezig was den Koran te reciteeren. Hij werd aangesproken door een kleinen ouden man met een baard. Deze vroeg hem wat hij kwam doen. Toen vertelde Jakobs vader van de zorg, die hem vervulde bij het naderen van de gevreesde ziekte. De oude heer zei hem echter geen zorg te hebben, en naar huis terug te keeren. Nadat ze elkaar de hand hadden gegeven, nam hij den terugweg aan. Bij de vier waterstralen gekomen, wiesch hij zich het gelaat, en hiervan schrok hij wakker. Bij zijn ontwaken vond hij in zijn hand een steen, 
die er als glas uitzag. Jakobs vader begreep, dat hij in den droom een ontmoeting had gehad met den pokkengeest, en dat deze hem den steen in de hand had gedrukt, als het geneesmiddel tegen deze ziekte. Toen de pokken dan ook werkelijk hun intrede in het dorp deden, legde de sando den steen in water, en liet de aangetasten daarvan drinken. Dezen herstelden allen!

Van een anderen sando hoorde ik, dat hij alle menschen prophylactisch 4 maispitten en 4 stukjes gember liet eten; in vier dagen mocht men dan niet baden; wanneer gedurende die 4 dagen geen menschen door de ziekte waren aangetast, mocht men weer baden. Waren enkelen ziek geworden, dan moesten allen nog eens 4 maispitten en 4 stukjes gember eten, en werd het verbod van niet baden gehandhaafd. Daarbij mocht op geenerlei wijze gerucht worden gemaakt, en geen dieren mochten worden geslacht.

Wanneer de ziekte had uitgewoed, werd een feest gevierd bij het Hoofd aan huis. Dit heet moloeba. In het Lingketengsche noemt men het ook njiat (door 't Mal. uit 't Arab. nyat ,voornemen, plan'). Hierbij wordt weer de stamvader (pilogot), en de overige zielen der afgestorvenen aangeroepen, waarbij hun gesmeekt wordt om de menschen in den vervolge tegen een herhaling van zoo'n ramp te beschermen. Priesters doen hierbij hun werk om van de geesten te weten te komen of de ziekte zal terugkeeren (van het wegzenden van de ziekte door het laten afdrijven van een prauwtje, waarin allerlei offergaven zijn gelegd, weten de Loinangs niets. Ook het bij andere stammen van Midden Celebes veel voorkomende aanstrijken van de menschen met bloed van geslachte dieren, ten einde hun levensgeest daarmee te versterken, is bij de Loinangs onbekend).

\section{L a n d bouw.}

Alle Loinangs verbouwen rijst op droge velden. Sawahs heeft men nooit gekend. Uit het geschiedkundig deel van dit opstel hebben we gezien, dat de oorspronkelijke bevolking geen rijst verbouwde, maar dat ze dit gewas heeft leeren kenen door later binnengekomen immigranten, met wie ze zich heeft vermengd, en van wie ze dus ook de cultuur, die met den rijstbouw verbonden is, moet hebben overgenomen.

Den Lingketeng-menschen is de mythe bekend, dat de rijst zou zijn voortgekomen uit een mensch. Men vertelt: Een nabi (eig. „profeet", maar bij natuurvolken als de Loinangs wordt met dit woord een onbekende grootheid aangeduid) stuurde eens zijn dochter er op uit om voedsel te zoeken. $Z$ e weigerde aan dit bevel te voldoen, en de 
vader werd hierover zóó boos, dat hij zijn dochter doodde, het lijk in stukken hakte, en de deelen overal verspreid begroef. Uit die lichaamsdeelen groeiden allerlei gewassen op: het bloed werd rijst, de tanden mais, uit het hoofd groeide een kokosboom op, uit de galblaas kwam tabak voort.

Wanneer men akkers aanlegt, vereenigt men zich tot gezelschappen, die elk hun velden aaneengesloten, als één geheel, maken. Zoo'n landbouwgemeenschap heet sambaba, en ze staat onder leiding van een voorganger, de tanaas (anderen zeggen tonaas). Een aanvoerder in den krijg (talenga) kan ook als landbouwvoorganger optreden. De tanaas moet den tijd bepalen, waarop men met het akkerwerk zal beginnen. Dit doet hij in verband met den stand der sterren (mandala). Deze zijn dezelfde als bij de andere stammen die Midden Celebes bewonen: mian daisan ,de vele menschen”, zijn de Pleiaden: mian totoloe ,de drie menschen”, is de naam voor den gordel van Orion. Het is vooral de laatste die voor den landbouw van beteekenis is. Wanneer de drie sterren bij het aanbreken van den dag in het midden van den hemel staan, is de tijd voor het openen der akkers aangebroken. ${ }^{1}$ )

De tanaas (of tonaas) heeft twee assistenten, van wie de eerste den naam draagt van pombebe' $i$, en de ander dien van pahemata. ${ }^{2}$ ) Bij den landbouw is hun functie van geen beteekenis, maar wij vinden ze terug als luitenants van den aanvoerder in den oorlog. Met hun drieën vormen ze een soort van raad: ze overleggen wat de teekenen kunnen beduiden, en ze vragen naar elkaars meening voordat de tanaas er toe overgaat een of ander gebod of verbod uit te vaardigen, in verband met de akkerwerkzaamheden. De pahemata is tevens degeen, die de regelingen, welke de tanaas maakt, aan de akkergenooten, de olitaoe (eig. ,,jongmensch, ongehuwd man”, Poso : ngalitaoc) over te brengen; hij geeft hun kennis, wanneer men bij den tanaas moet samenkomen en derg. Na afloop van den oogst geeft elk gezin een mandje (kaliaing) met gepelde rijst en een hoen aan den voorganger (tanaas).

1) In de Minahassa heet de landbouwpriester tonaas. Dit woord vindt men bij de Toradja stammen terug in motonaa ,wichelen”. Bij de Sa'dan toradja's is het tominaa ,priester".

2) Dit pahemata vinden wij bij de Posoërs terug in paramata „edelgesteente”, de titel van een voormalige waardigheidsbekleeder in Loewoe. De Hoofden met dezen titel hadden het onmiddellijk toezicht over een landschap, in dien zin dat zij door den heer des lands naar die streek werden gezonden, wanneer dit om de eene of andere reden noodig was. Het waren dus meer zendelingen die een boodschap van den heer des lands kwamen overbrengen. 
Deze deelt deze inkomsten met de beide anderen, in dier voege, dat hij er zelf drievijfde van neemt, drietiende aan den pombcb'i en ééntiende aan den pahemata geeft.

Men begint met het omhakken van het hout al in de tweede helft van Augustus, zoodat in de maand Mei het oogsten is afgeloopen. Men snijdt dus de rijst in een tijd, dat de meeste regen valt. Men doet dit omdat men heel bang is voor den sterken Zuidoosten wind, die baleba hect, en die soms al in Mei doorzet (de moesonwind uit het Noorden heet nombosoen). Wanneer het gewas door dezen wind overvallen wordt, terwijl de vrucht aan het uitkomen is, zullen alle aren loos zijn. De dorpen, die op den Lingketeng-heuvelrug liggen, hebben soms veel van dezen wind te lijden. Ik zag daar dan ook vele huizen door middel van zwaren rotans met de omringende boomen verbonden, ten einde te voorkomen, dat de baleba-wind ze omver zou blazen.

De tanaas heeft in de eerste plaats na te gaan of de teekenen voor den landbouw gunstig zijn, maar hij doet dit pas wanneer men al een aanvang met het werk heeft gemaakt. De mannen gaan dan een hut bouwen midden op het terrein, dat door een heele akkergemeenschap zal worden ontgonnen. Wanneer de hut gereed is, gaan tegen het vallen van den avond daarheen: mannen, vrouwen en kinderen. Men maakt niet ver van de hut een offertafeltje, talaian, en als de avond valt, legt men er een offer op: gekookte rijst en een gekookt ei, dat men in vier parten heeft gedeeld. Verder twee inheemsche sigaretten. Bij de offertafel is nog een rekje opgericht, waarover kleeren worden gehangen van alle leden van de akkergemeenschap. Ten slotte worden de speren der mannen er bij in den grond geplant: voorop die van den tanaas, dan die van zijn assistenten, de pombebe'i en de pahemata, en dan die van de andere menschen. Elk gezin heeft gezorgd voor een klein matje, dat van kokosblad is gevlochten, en dat den naam draagt van tompakoea. Dit legt men bij het offertafeltje op den grond, en daarop plaatst ieder gezinshoofd een dergelijke offerande als op de talaian ligt.

Wanneer men hiermee klaar is, plaatst de tanaas zich vóór het offertafeltje, dat hij vasthoudt; alle mannen, vrouwen en kinderen, die tot zijn akkergemeenschap behooren, scharen zich aan zijne rechterzijde. Een der aanwezigen telt dan uit hoeveel menschen, groot en klein het gezelschap bestaat; laat ons zeggen, dat het 50 zielen telt. $\mathrm{Nu}$ verheft de tanaas zijn stem en zegt: Komioe atoenae atina, komioe tominoeat, apa kita sampoeoes, ngkan mae kakadian, atina 
likidjii ka nggalaoc, moko kan nggalaoe, monginocm doeang, moko inoem doeang, momangan, moko pangan saidi koetoetoengi dje na gaoe; ka otimbang mae; otimbang mae na kami aia, mompaas tano aia, kon sahoebaan mboele, mohopoe mboele, kami miannjo limampoeloe, madi mboele ko anoe oala mami $i$ tano aia, notabas mboele mian noe laoon; io saidi koetoetoengi na gaoc, metoedang noe pintoloeng, $k a$ meotewa noe salebak maliana. „Gij moet hier tegenwoordig zijn, gij zielen der afgestorvenen, want wij (zoeken) levensgeest. Komt $\mathfrak{u}$ hier te goed doen, hier is rijst met ei; als gij de eieren hebt gegeten, drinkt dan palmwijn ; als ge palmwijn gedronken hebt, pruimt dan sirih-pinang; als ge gepruimd hebt, zal ik aanstonds de sigaretten voor $\mathrm{u}$ aansteken; en kijkt dan hierheen, kijkt naar ons hier, die dezen grond gaan schoonmaken, of wij tegenspoed zullen krijgen, of wij (in menigte) zullen sterven, wij die met ons vijftigen zijn; moge er niets zijn, dat ons op dit land zal overkomen, dat wij ook niet door krankzinnigen gesneld mogen worden; zoo aanstonds zal ik de sigaretten voor $\mathfrak{u}$ aansteken, komt dan zien naar het driemaal (geschreeuw der vogels)". (Het laatste van de aanroeping kan ik niet iertalen).

$\mathrm{Na}$ deze bede zet men zich aan den maaltijd, en als men daarmee gedaan heeft, steekt de tanaas de beide sigaretten aan, die op het offertafeltje liggen. In dien nacht luistert de voorganger naar de vogelgeluiden, waarin hij bijgestaan wordt door de andere mannen van het gezelschap, als dezen er niet de voorkeur aan geven te gaan slapen. In de eerste plaats wordt op het gekras van de uil gelet, dat men weergeeft met koëk! Maar deze tonen kunnen met allerlei variaties geuit worden. Roept de vogel eenvoudig koëk! dan heet dit mengkoëk; roept hij: kikokokoëk, dan heet dit po'o boekoe, en dit geluid wordt als zeer gunstig aangemerkt. $\mathrm{Nu}$ en dan roept hij é é é! Dit is ten allen tijde ongunstig. Roept hij eens of driemaa! koëk! dan is dit ook ongunstig, tweemaal is beter, maar viermaal is 't beste. Van al de varianten in dit geroep, gaf men mij als het meest gunstige op: Wanneer de uil in den voornacht viermaal koëk! roept, en tegen het aanbreken van den morgen kikokokoëk! laat hooren.

De meest onheilspellende combinatie is, wanneer men in den voornacht niets dan é é é! hoort, en de vogel tegen den morgen slechts eens de kreet koëk! uit. In dit geval zit er niet anders op, dan dat men een ander terrein gaat zoeken om er zijn akkers op aan te leggen. De beide genoemde uitersten komen naar het getuigenis der menschen 
zelden voor. Tusschen die twee in liggen allerlei combinaties, die den menschen in elk geval veroorloven daar te blijven. Het komt er bij het vernemen van ongunstige geluiden op aan, of deze door later opgevangen gunstige kreten te niet worden gedaan of niet.

Het geluid van andere vogels is van bijkomstige beteekenis. Wanneer bevoorbeeld een kaketoe (kea) in dien eersten nacht schreeuwt, zegt men dat men veel rijst zal krijgen. Zoo hoort men niet graag het grommen van den djee-vogel (Poso: tcka-tcka, Phoenicophaeus calyorinchus); men is dan geneigd een ander terrein voor zijn akker te gaan zoeken. Laat deze vogel een lachend geluid hooren, dat men madjama noemt, dan voorspelt dit voorspoed.

Wanneer de resultaten van het nachtelijk onderzoek gunstig zijn geweest, wordt den volgenden dag het boschland onder de gezinnen verdeeld, en er worden merkteekens aan de boomen gegeven om te weten voor het ontginnen van welk deel ieder voor zichizelf heeft te zorgen. Later, wanneer de grond is schoongemaakt, en men tot planten zal overgaan, worden overal stukken hout (mbatang) op de aarde neergelegd om de grens (tempas) aan te geven. Eertijds plantte men osole (Coix agrestis) om de verschillende akkers van elkaar te scheiden. Maar sedert men kennis heeft gemaakt met de mais, is de cultuur van osole sterk achteruit gegaan. Daar de Coix geplant wordt, zoodra het hout is verbrand, was dit een goede manier om de grenzen aan te geven.

$\mathrm{Na}$ de verdeeling van den boschgrond wordt gedurende den nacht, die daarop volgt, weer naar de vogelgeluiden geluisterd. Als dit ook gunstig is, komt men in den morgen te zamen om te mongahat, een begrip, dat niet met een enkel woord is weer te geven. Ieder die iets ervaren heeft, waarvan hij meent, dat er een voorzegging van de toekomst in gelegen is, vertelt deze ervaring aan de anderen, opdat vooral de tanaas en zijne assistenten daaruit de beteekenis zullen kunnen opdiepen. Meestal zijn het droomen, die men elkaar heeft te ver. tellen. Iemand vertelt bijvoorbeeld, dat hij in dezen nacht heeft gedroomd, dat hij een rivier stroomafwaarts volgde tot hij aan een kolk (likoe) in de rivier kwam, die aan beide kanten door steenen wanden was ingesloten. Hij wilde toen verder gaan, maar schrok wakker. - Dan wordt over het geval gepraat, en men komt tot het besluit, dat de zin van den droom gunstig moet wezen voor den droomer: zijn akker zal veel rijst voortbrengen, maar niet in gelijke mate; er zullen plekken zijn met een overvloedige opbrengst, en andere stukken zullen minder vrucht dragen. Want dit wil toch het 
verschil beduiden in diepte van het water: in den stroom zelf weinig water, in de kolk veel water.

Een ander vertelt: „In mijn droom kwam ik in een huis, waar men feest vierde. Men noodigde mij uit om deel te nemen aan het maal; en ik kreeg varkensvleesch te eten. Toen werd ik wakker". Men blijft elkaar een poos zwijgend aankijken, want men voelt al dadelijk iets in dezen droom, dat niet gunstig kan zijn. Ten slotte verklaart de tanaas, dat de droomer moet sterven, als hij op het hem aangewezen stuk grond gaat werken. Om dit te voorkomen raadt hij. aan, dat de droomer met een ander van grondstuk ruilt. Dan wordt uitvoerig overleg gepleegd met wien hij van land zal ruilen, totdat ook dit naar aller genoegen is geregeld.

$\mathrm{Nu}$ komt een derde met de mededeeling, dat hij in den droom in een pinangboom klom, en daaruit een tros noten naar beneden bracht. Hierover behoeft niet lang te worden nagedacht, en van meer dan één kant wordt de overtuiging uitgesproken, dat deze droom een rijken oogst belooft. Want er zijn van die droomen, die een vaste beteekenis hebben: Als men zich in den droom in helder water baadt, zal men veel rijst oogsten; doet men dit in troebel water, dan zal men met veel onkruid te worstelen hebben.

Wanneer ieder gezegd heeft wat hij op het hart heeft, en de algemeene indruk van de aanwijzingen gunstig is, komt men na drie dagen weer op dat land bijeen om zijne bevindingen in droomen en andere voorteekens nog eens te bespreken. Wanneer ook hierin geen aanleiding wordt gevonden om van bouwland te veranderen, wacht men nog eens 4 dagen om dan een begin te maken met het kappen van het onderhout en het struikgewas (dit heet mongahe of mompaas).

Den eersten dag bewerkt men slechts een klein stuk van het land, dat aan den leider (tanaas) is toegewezen. Den volgenden dag werkt men dit af, en daarna gaat ieder het stuk land bewerken, dat hem is toegewezen, waarbij men elkaar wederkeerig helpt.

Als men onder dezen eersten arbeid een muis vindt, en het gelukt haar te dooden, dan zal men veel rijst krijgen. Gelukt dit niet, dan is de kans op een goeden oogst minder, maar men gaat toch voort dat land te bearbeiden. - Wanneer men een locloen djaling of een oelo wonti (twee soorten van slangen) aantreft, dan doodt men ze, maar men heeft de overtuiging, dat voordat de rijst, die op dezen akker geplant zal worden, binnengehaald is, een familielid zal zijn overleden. Toch zet men het werk voort. - Vindt men tusschen 
de boomen op het hem aangewezen stuk land 'een liaan, die in een lus is gegroeid, dan is dit een goed teeken, omdat de lus alles bijeenhoudt, er niets verloren gaat; men zal dan voorspoed hebben. Vindt men echter aan een bakolo-boom een blad, dat zich in tweeën heeft gedeeld, dan is dit een heel ongunstig teeken, dat er toe noopt een ander terrein voor zijn akker te zoeken.

Wanneer men klaar is met het onderhout, begint men de boomen te vellen (monto'alei), weer het eerst op het land van den leider der gemeenschap. Staat er op dit terrein een bizonder groote boom, dan moet de priester uitmaken of in dien boom een geest woont of niet. Dit is al vastgesteld, voordat men het terrein in bewerking heeft genomen, want het gebeurt wel, dat de boehake-geest door den mond van den priester de mededeeling doet, dat de geest, die in den boom verblijf houdt, zóó gevaarlijk is, dat men beter doet daar geen akker aan te leggen. Is de geest wel genegen zijn woonplaats te verlaten, dan steekt men bij den boom een bamboestaak in den grond, waaraan men een streng kralen van sole-vruchten (Coix lacryma Jobi), rijpe pisang, sirih-pinang en tabak hangt; men zegt er bij: „Dit is de prijs voor dezen boom, dien ik wil omhakken”. Zoo'n handeling heet mompalati.

Als men het gehakte hout, dat men in stukken heeft gekapt (monoso), en dat inmiddels in de zon droog geworden is, zal gaan verbranden (mompapoei), maakt men daartoe een fakkel van droge bamboe gereed, waaraan een bruine en een zwarte kippeveer wordt toegevoegd, waarna de fakkel nog met kalk wordt bestrooid. Bruin (rood) zal het vuur echt warm maken; zwart doelt op de kool die overblijft, nadat het hout is verbrand; en dat het kippeveeren moeten zijn, heeft de bedoeling om te maken dat het vuur over den grond vliegt, zoo spoedig is alles in de asch gelegd. De kalk moet dienen om droog weer te tooveren.

$\mathrm{Na}$ het branden, wordt het verkoolde hout opgeruimd, en reinigt men verder den grond; dit alles heet mongakat.

Wanneer men zal overgaan tot het beplanten (mosoe'an) van den schoongemaakten akker van den leider, wordt daartoe een goede dag uitgekozen. Het mag bijvoorbeeld niet gebeuren op een dag, waar in den voorafgaanden nacht een vrouw bevallen is, want dan zou men veel last van muizen krijgen. In den nacht, die aan den plantdag voorafgaat, komen de akkergenooten te zamen op het veld van den tanaas; dit heet mombocha. In dezen nacht wordt weer naar de geluiden der vogels geluisterd. Een slecht teeken is, wanneer de 
keketi (een vogel die in Poso popoko heet) zijn kreten slaakt. Men moet het planten dan een dag uitstellen.

De tanaas heeft intusschen aan den rand van het akkercomplex, dicht bij den zoom van het bosch een offertafel opgericht, die in andere gevallen talaian heet, maar die bij deze gelegenheid pombe'ian „,waarop gegeven (aangeboden) wordt" genoemd wordt. Op dit toestel legt de tanaas gekookte rijst en een gekookt ei, dat in vieren gedeeld is. Dan spreekt hij den setan en de zielen der afgestorvenen toe en zegt: „Hier is uw aandeel; komt het onze niet halen”. Deze handeling heet mombe' $i$,geven".

Zoo gaat het bij de Lingketeng-menschen. Bij de Baloa-clan maakt de tanaas twee offertafeltjes aan den zoom van het akkercomplex, die hier als bij andere gelegenheden talaian heeten. Hij legt er het offer van gekookte rijst en ei op, en zegt: „Al wat hier binnen wil komen (apen, varkens, muizen enz.), hier is uw aandeel". De bedoeling van de aanbieding bij beide clans is dezelfde, want als setan en zielen van afgestorvenen (tominoeat) op den akker komen rooven, doen ze dit in de gedaante van de pas genoemde dieren.

Verder wordt bij beide clans door den tanaas nog een offertafeltje in het midden van de akkers gemaakt, waarop hij een zelfde offer van rijst en ei legt, en vraagt (aan wien kon men mij niet zeggen) om alle slangen uit den akker verwijderd te houden, waarmee bedoeld worden alle booze invloeden, die hun schadelijke werking op het gewas kunnen uitoefenen.

In beide clans heeft dan het volgende plaats: De tanaas heeft gezorgd voor een lansat-boompje (Loin. : baboeno, Lansium domesticum), of een silo-boompje, of anders een tak van dezé boomsoorten. Met silo worden verschillende ficussoorten aangeduid, wier vruchten met korte steeltjes aan den stam en de takken zelf groeien, bij sommige soorten rood, bij andere wit (de ficussoorten, die in Poso kampendo en pokae heeten, worden beide door de Loinangs silo genoemd). De kracht van de twee genoemde boomen wordt gezocht in den overvloed van vruchten, die ze voortbrengeri: de rijst moge dit voorbeeld volgen. Bij de lansat speelt de gele kleur der vrüchten nog een rol, omdat men verwacht, dat de rijst ook geel zal worden. Groeit er reeds zulk een boom op het te bewerken terrein, dan laat men hem staan, en maakt hem tot middelpunt van het akkercomplex. Aan den voet van den ficus wordt curcuma (kini) geplant. Men trekt er zich niets van aan als de geplante tak geen wortel schiet en doodgaat, wat gewoonlijk het geval is. 
De lansat- of ficustak wordt bij het offertafeltje midden op den akker geplant. Deze plek heet okoeman. Daar wordt op den dag, dat men zal planten, de mand (basoeng of batadi) met plantrijst neergezet op vier stukjes hout van de genoemde ficussoorten. Boven in de mand met plantrijst is een booeang gelegd, dit is een bakje van pandan of andjala-blad; in dit bakje liggen 1 pinangnoot; 1 sirihvrucht, 1 stukje curcuma en 1 stukje kokosvleesch; met dit bakje zal de eigenares van het veld straks de zaairijst uit de mand scheppen om die uit te deelen aan de vrouwen en meisjes, die het zaad zullen storten (mombocoe) in de pootgaten, die de mannen in den grond hebben gestoken.

Wanneer men nu met planten zal beginnen, loopt de tanaas voortdurend met zijn pootstok gaten in den grond stekende, viermaal om de okoeman heen, zoodat er vier kringen van gaten ontstaan, die door zijn vrouw, die achter hem aan komt, met rijst worden gevuld. Bij het steken van het eerste gat, zegt de man: „Mijn rijst gelukke, het onkruid zij kort, de rijstplanten lang”. Nadat hij zijn werk heeft gedaan, wordt de pootstok (pontoegan), die van hard hout moet zijn gemaakt, bij den ficustak in den grond gezet, en deze blijft daar het heele jaar staan. Dit planten om de okoeman heen heet momboeliling „er om heen loopen”. $\mathrm{Na}$ afloop hiervan gaan de aanwezigen den heelen akker beplanten. Als het planten gedaan is, maken in 't Lingketengsche jongens en meisjes elkaar zwart met de overal verspreid liggende houtskool. Dit geeft anleiding tot veel pret.

$\mathrm{Bij}$ de Lingketeng-clan heb ik niet veel gemerkt van de beide assistenten van den tanaas. Wanneer ik naar hen vroeg, antwoordde men, dat men ze in die streek ook kende. Maar ik heb den indruk gekregen, dat het in gemeenschap werken onder een tanaas bij deze menschen niet meer zoo geregeld plaats heeft als bij de Baloa-lieden. Velen in het Lingketengsche leggen hun akkers op zichzelf aan.

De leden, olitaoe, van de akkergemeenschap maken geen offertafeltjes; maar wel plant ieder in het hem toegewezen stuk grond een ficustak en makt er een okoeman, die ook bij den oogst een rol speelt.

$\mathrm{M}$ a a $\mathrm{nd}$ a g e $\mathrm{n}$. De Loinangs houden ook rekening met de maanphasen, waarnaar de dagen worden genoemd. Evenals bij alle volken op Midden Celebes worden de dagen tijdens de wassende maan slechts geteld. Wanneer iets van de maansikkel te zien is, heeten die nacht en de daarop volgende dag koloa. Dan volgen koloa oeampaho, 
koloa toloempaho enz., d.i. de tweede koloa, de derde koloa enz.; totdat de elfde dag weer zijn eigen naam heeft: magesoek. Dan volgen verder 12. molompo. 13. timoemoen, 14. oeloenjo, 15. toemba, 16. baani, 17. kobinsihan, 18. kakas, 19. tobongbaloe, 20. toemangaha, 21. oemoto, 22. kolioe ise, 23. kolioe daka, 24. matanjo, 25. tongaknjo, 26. toeonjo, 27. posoknjo, 28. boelan i oeno, 29. hagaion.

Ik ben niet genoeg met het Loinangsch vertrouwd om mij aan een verklaring van al deze namen te wagen. De 19e (tobongbaloe), de 22e ( $k$ olioe ise), de 26e (toe'onjo) en de 27e (posoknjo) dag zijn ongunstig voor den landbouw. Wanneer men op die dagen op den akker ging werken, zouden muizen den aanplant vernielen. Baani (Mai.: berani „,dapper") en tinoemoen zijn goede dagen om daarop van huis te gaan, als men een tocht gaat ondernemen; ook als men in den ouden tijd een koppensnellerstocht ging ondernemen. Met het laatstgenoemde doel mocht men nimmer op kakas van huis gaan, want dan zou men niets dan ellende ondervinden.

$\mathrm{Bij}$ het wieden (montetep, mongaoet) van de rijst valt niets op te merken. Wanneer het gewas teekenen van ziekte vertoont, besprenkelt men het met water, dat door iemand die de kunst kent, beblazen of besproken is. Al sprenkelende loopt men op den akker rond, steeds meer de okoeman (de ficustak bij het offertafeltje) naderende. Als men daar is aangekomen, wordt de bamboekoker waarin het water is geweest, bij den tak neergezet. Of men verzamelt droge takken van den doda-boom (Mal.: dadap, Erythrina hypaphorus), en verbrandt die aan den kant van den akker, vanwaar de wind komt, zoodat de rook van het vuur over den heelen akker wordt verspreid. De kracht van dit middel zit waarschijnlijk in den naam van dit hout.

Wanneer het gewas bedreigd worlt door een insekt oehop (Mal.: walang sangit. Leptocorisa acuta), die het vocht uit de zich vormende korrels zuigt, dan kauwt de akkerleider (tanaas) ui of kalk, en spuwt dit hier en daar over de planten. Vogels die de rijst eten, zijn er in twee soorten: roode, die koeloendii heeten, en peheet, het gewone rijstvogeltje, dat soms in groote scharen op de rijst neerstrijkt. In dit geval spant men rotan lijnen (bantang) over den akker, waaraan bladeren zijn opgehangen, die in beweging worden gebracht door aan de lijnen te trekken, zoodat de vogels verschrikt opvliegen. Men verjaagt ze ook door stukken bamboe tegen elkaar te laten tikken; zoo iets heet galasa; of men splijt een bamboe, en laat de beide helften tegen elkaar kleppen; zoo'n toestel heet koepak-koepak. Molentjes (pili-pili) die door den wind worden rondgedraaid, en dan een piepend 
geluid maken, maakt men ook wel eens; maar eigenlijk zijn ze verboden; waarom men ze niet mag maken, wist men mij niet te vertellen.

Tegen het binnendringen van varkens beschermt men den akker door het planten van scherpe bamboes, waaraan deze dieren zich verwonden. Soms zijn het een soort luizen (antila) die de rijst aantasten. Om deze plaag tegen te gaan brandt de tanaas op verschillende plekken in het veld de schil (boenoet) van kokosnoten. Ditzelfde doet hij ook tegen een ziekte van de mais, wanneer deze plant door wormen (kö̈) wordt aangetast.

Wordt een aanplant door muizen (bokoti) geteisterd, dan haalt de tanaas de vruchten en de wortel van sampangadje; deze kauwt hij, en dan loopt hij steeds strak naar den grond kijkende door het beschadigde veld, en spuwt nu en dan van het kauwsel op de aarde, tot hij aan den rand van de nakker is gekomen. Dan kijkt hij plotseling op, en spuwt in de wildernis vóór zich. Alle muizen zullen zijn weg volgen, en alleen eten van de planten die buiten den akker groeien, in de richting waarin zijn blik is gegaan (door het plotseling opkijken heeft hij de diertjes met zijn blik buiten den akker geworpen; de kracht van de plant waarvan hij wortel en vruchten kauwt, ligt weer in den naam: sampang is ,slachten”, de deelen van het lichaam van elkaar scheiden, en adje is „kin”, ,kaak”; de onderkaak, waarmee ze knagen zal den muizen worden afgehouwen).

Wanneer een akker met medicijn is behandeld, mag niemand er gedurende 3 dagen komen, opdat de krachtige doorwerking van de medicijn niet worde verstoord.

Ik noem hier even de namen, die men voor de verschillende standen van de rijst heeft: wanneer de loot uit de korrel is gebroken, heet dit soemae; komt het blaadje boven den grond uitkijken, dan noemt men dit soe'oen boehing ,de houtskool op het hoofd dragen", omdat de top van het plantje de houtskooldeelen, waarmee de akker na het verbranden van het hout bedekt is, oplicht; sampon heet het, wanneer de plantjes zijn te zien, en de grond met een zacht groen kleed is bedekt; sombolitoetoek, de blaadjes buigen zich naar beneden om; topoboentoeng, de planten staan in vollen bladerdosch; tiandië, wanneer de stengel zwelt door de wordende aar; ndoei, de plant is zwanger; sikabeebong, wanneer det aar op doorbreken staat; mobongkas ,er uit gebroken”, nl. de aar uit de halm; bilat mata, de oogen dwalen rond om hier en daar te blijven rusten op de planten, die hun aren in de hoogte steken; goema nggaho, alle planten dragen nu hun aar; tombontoeloeng, beginnen om te buigen van de aar, doordat 
de korrels zich beginnen te vormen; tombongkaloe', geheel omgebogen door de zwaarte van de vrucht; toembalon, de uiteinden van de aren beginnen geel te worden; poepoesmo na tinanjo, de moeders (tina) d.z. de oorspronkelijke planten, dus niet de later bijgekomen spruiten, zijn rijp. Dan volgen spoedig de anak ,kinderen”, d.z. de planten, die er na het stoelen van de rijst bijgekomen zijn. En dan kan men beginnen met oogsten.

Ook de Loinangs kennen vele soorten van rijst. Men beweert dat de eerste rijst, die in Loinang geplant is tomonihoet is. Hier volgen nog enkele namen van de meest voorkomende soorten: limboejoeng, tomoiki (de naam van een landstreek in Mori), bosoe, loempane, pae balan, landoejoe (een roode soort), pae langkojan, djambaha, koengkoeng, talaboet, labangi, adjahan, pae oean. Van de kleefrijstsoorten noem ik: pae langkai, bonoi.

Voordat de tijd is aangebroken dat de rijst kan worden gesneden, wordt de mais (binde) geoogst. Zooals reeds gezegd is, wordt deze vóór de rijst geplant, en daar ze sneller groeit dan deze, zijn de maisplanten uit den akker verwijderd, voordat de vrucht van de rijst uitkomt; ze kunnen de rijst dus niet door hun schaduw belemmeren. Wanneer nu de maisvruchten uitkomen, moeten voor het geheele veld een aantal verbodsbepalingen in acht genomen worden, die moeten worden volgehouden tot na afloop van den oogst. Men mag dan geen rotan meer snijden in de nabijheid van den akker; men mag geen springlans opstellen in den akker om varkens te dooden, die op de mais afkomen; wanneer men succes heeft gehad op de jacht, mag men het wild niet op den akker roosteren, maar men moet dit daarbuiten doen. Als men zich aan deze regels niet stoorde, zou er noch van de mais, noch van de rijst iets terecht komen. De leider (tanaas) mag zich in den eersten tijd, nadat de velden beplant zijn, elders heen begeven, maar tegen den tijd dat de mais rijp wordt, moet hij bij het akkercomplex, dat aan zijn zorgen is toevertrouwd, blijven, totdat de oogst is afgeloopen.

Op een afgesproken dag brengen alle akkergenooten eenige jonge maiskolven aan den leider (tanaas). Deze roostert er 2 of 4 van, legt ze op een bord en biedt ze den kinderen van de boehake-geesten en de zielen (tominoeat) van gestorven kinderen aan. Daarna worden die 2 of 4 vruchten door de kinderen van den akkerleider (tanaas) opgegeten. De overige maiskolven, die zijn samengebracht, worden ook geroosterd, en deze worden onder de kinderen der akkergenooten verdeeld. Dan keert men naar zijn eigen tuinhut terug, en schrapt de D1. 86. 
nog zachte korrels van jonge maiskolven af; dit wordt in bamboes gekookt; deze spijs heet kiningki. De bamboes worden alle naar den tanaas gebracht. Deze legt er een deel van op de offertafel, en het overige wordt gezamenlijk genuttigd. Dit feestje heet monsazve binde „mais bovenop brengen” (op de offertafel). Den volgenden dag doet men hetzelfde bij den eersten assistent, den pombebe'i, en den daarop volgenden bij den anderen, den pahemata. Inmiddels is de mais tot volkomen rijpheid gekomen.

Het is weer de leider (tanaas) die begint met het binnenhalen der maiskolven; daar zijn akker het eerst beplant is, levert deze ook het eerst vrucht. De eerste 4 of 7 kolven, die hij afsnijdt, rijgt hij aan een rotan (zoo'n rist maisvruchten heet kaladang of pangkae). Deze rist eerste vruchten wordt op het offertafeltje bij de okoeman in het midden van het akkercomplex gelegd. Alle akkergenooten brengen daar zoo'n rist van eerste vruchten, en die blijven daar liggen als aandeel van de geesten. Bracht men dit offer niet, dan zou de mais òf door de muizen worden gegeten, òf men zou telkens als men er van at, buikpijn krijgen.

O o g s t e n. Wanneer men nu de rijst zal gaan snijden, is het weer de akker van den leider, waar dit 't eerst gebeurt. Voor elken akker is een voorgangster bij den oogst angewezen, die meestal de vrouw van den eigenaar van het rijstveld is. Ze heet mian momboea takilon, degeen die de takilon draagt. De takilon (in Baloa wordt dit mandje ook wel patembang genoemd), is een open mandje, dat alleen de voorgangster bij het snijden van de rijst om het middel heeft hangen; dit mandje onderscheidt haar dus van de anderen die haar helpen. ${ }^{7)}$ Voordat zij aan het werk gaat, verzamelt zij eerst allerlei boombladeren en kruiden, die als medicijn voor de rijst dienst moeten doen, en die door hun naam of eigenschap moeten maken, dat de rijst niet wegloopt (minder wordt). Zulke medicijn neemt men van de kalaisi, paseket, pohon djongi, peboeke, peantok, pebawo, panakoe, loia (gember). Al die bladeren en kruiden worden in stukjes gesneden, en daarvan worden pakjes gemaakt.

Wanneer ze den akker opgaat om te oogsten op den eersten dag, maakt zij nog geen gebruik van de medicijn; ze laat die in de veldhut achter, en snijdt van de rijst in het rond; deze rijst doet ze in haar mandje (talikon), en als dit vol is, stort ze den inhoud in een grootere

1) Op de reproductie van Kaudern's schilderij tegenover bl. 320 in het tweede deel van zijn I Celebes obygder, is de talikon duidelijk te zien. 
mand (basoeng) over. Zijn op deze wijze twee van die groote manden gevuld, dan houdt ze op. Deze eerstgesneden rijst heet doehoekan; deze wordt zonder ze eerst te ontbolsteren (dus met de schil er om) gekookt; dit heet mompohii. Daarna worden de korrels op het rek boven het vuur gedroogd, en vervolgens gestampt. Dit stampsel wordt in van palmbladeren gevlochten zakken (balase) en in mandjes (kaliding, booeng) bewaard om later te worden gegeten.

Daarna doet de voorgangster de pakjes oogstmedicijn in haar mandje en gaat weer snijden, maar nu doet ze dit systematisch. Het hooger gedeelte van den akker heet oebakan, het beneden deel noemt men de bolokan, en de beide zijden heeten habe. De akker wordt op het oog in eenige vierkante vakken verdeeld, op de wijze die de figuur aangeeft. De voorgangster gaat altijd van links naar rechts,

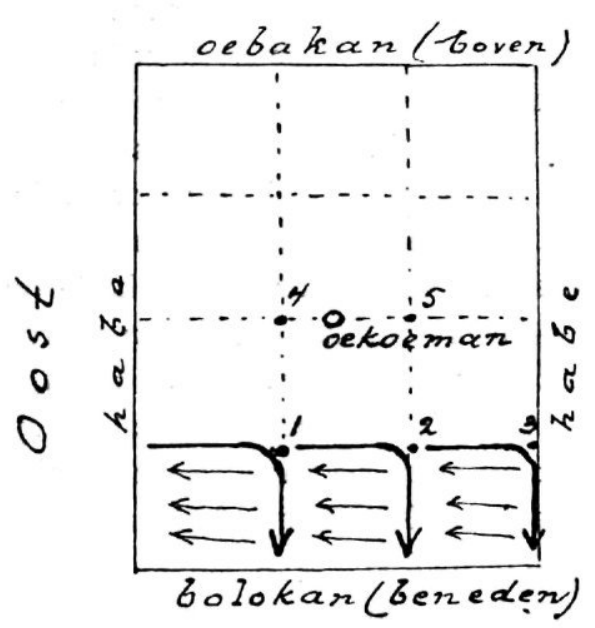

Plattegrond van een rijstveld als dit afgeoogst wordt. Op 1, 2, 3 enz. wordt het offerhutje (langka) opgericht. De gebogen pijl geeft de richting aan, waarin de voorgangster bij den oogst, de rijst snijdt. De rechte pijltjes geven de richting aan, waarin hare helpsters zich snijdende bewegen.

en maakt eerst in het hoekpunt 1 een eenvoudig miniatuur huisje, langka genaamd, waarin ze haar medicijn neerlegt; daar ook bindt ze vier rijststoelen met hun eigen bladeren aan elkaar vast, en legt daarin een pakje van haar medicijn neer. Aan den voet van die saamgebonden planten zet ze een betelmandje (singkolop, van pandan gevlochten) neer, en ze spreekt de planten toe, en vraagt aan de 
toempoe noe pae ,de eigenaar van de rijst", de rijstgeest, om veel rijst. De aren van den saamgebonden stoel snijdt ze af, en legt die op het sirihmandje. Deze plek heet panganian „waar men sirih te pruimen geeft". Het afsnijden van deze aren en het leggen er van op het mandje heet mobengke-bengkele'i.

$\mathrm{Nu}$ begint ze te snijden van links naar rechts gaande. Sommigen zorgen er voor steeds met het aangezicht naar het Oosten gekeerd te zijn, maar anderen beweren dat dit er niet op aan komt. Terwijl de voorgangster als het ware een breede gang om het eerste vierkant heen snijdt, zijn degenen die haar bij dit werk helpen, bezig het vak verder af te oogsten. Die helpsters moeten steeds zorgen niet achter de voorgangster te loopen, want dan zouden ze flauw vallen. Alle bossen, die van dit vak komen, worden bij het hutje op 1 opgestapeld. Zoo'n stapel rijst heet tompoeson.

Wanneer het eerste vak zoo goed als klaar is, verplaatst de voorgangster het hutje (langka), met de oogstmedicijn daarin naar het hoekpunt 2 van het tweede vak, en begint weer een gang van links naar rechts te snijden, terwijl haar helpsters alles wat binnen dien gang ligt, afhalen. De bossen van dit vak worden in 2 opgestapeld, zoodat daar ook een tompoeson ontstaat. Daarna wordt het hutje naar 3 verzet, vervolgens naar 4, 5, 6 enz. tot het heele veld is afgeoogst.

Komt men bij de okoeman, dan oogst men de rijst van die plek gewoon met de andere mee. Wanneer er 4 of 5 tompoeson of stapels rijst zijn ontstaan, maakt de eigenaar van den akker op het afgeoogste stuk grond een hut (bahahan genaamd, eigenlijk niet meer dan een vloertje op palen met een dak er boven); hierin bergt hij al de rijst van den akker achtereenvolgens op.

Wanneer vreemdelingen op den akker komen waar men bezig is met oogsten, moeten ze denzelfden weg, dien ze gekomen zijn, weer teruggaan; hun wordt niet toegestaan om het veld heen te loopen. Geven ze hieraan geen gehoor, dan worden ze beboet met aarden bordjes.

De voorgangster bij den oogst heeft een aantal voorschriften in acht te nemen. Ze mag niet baden voordat één vierkant is afgeoogst. $\mathrm{Bij}$ het Baloa-volk mag ze alleen baden, als het donker geworden is. Ze mag alleen warm water drinken en ze mag niet koken. Hoenders mogen gedurende het oogsten niet geslacht worden. Geen voorbijganger mag haar toespreken. Deed iemand dit, dan zou hij beboet worden met een hoen, sirih, pinang, tabak en gember; dit alles moet aan de voorgangster gebracht worden. Men mag nooit 
achter of links van haar voorbijgaan, want degeen die dit deed zou er ziek van worden.

Onder het oogsten moeten allen zich van de oogsttaal bedienen. Men gelooft vast, dat ieder die een woord zegt, dat verboden is, flauw zal vallen. Soms geeft men daarbij bloed op. De voorgangster moet zoo iemand dan weer bijbrengen met gember, die ze uit haar mandje haalt. Men vertelde mij in vollen ernst, dat als een vogel over een veld vliegt waar geoogst wordt, hij dood ter aarde valt. Maar niet alleen de mensch zelf moet de schadelijke gevolgen ondervinden van het verwaarloozen van de oogsttaal, ook de rijst zal er minder door worden; ze verdwijnt.

Hier volgt een lijst van de woorden van de oogsttaal:

Pae ,rijst” wordt bonjo; oe ë ,water”: anggan; kaoe ,hout”: hengkot; hoon ,hlad": tambeako; basoeng „draagmand": koemba; apoe ,vuur" en soeloe, ,harsfakkel”: pogoelot (Baloa), pobilat (Lingketeng); doeang ,palmwijn”: anggam poete ,wit water" (Bal.), kohiboeon (Ling.) ; timoeson ,zout”: ote'on ; laigan of bonoea ,huis”: soong; balan ,aap”: loempat panga ,takken bespringer”; dedeng „hond”: dodi; onoeang ,gemsbuffel : koboeho; manoek „hoen”: aam (verg. Mal. ajam) B., poeloet L.; oedjan ,regen”: anggamon; bitoe'on „maan”: koloa of boelan; sina ,zon”: djingkele B., kahang L.; tindoeng ,regenmatje”: soeoet B., pinsihaho L.; bangko' „kapmes”: bangkoko B., bensit L.; mongkoemit of mompadak ,oogsten”: mombanit; kochon „kookpot”: pesaak; tigo ,tabak”: sohoba; popos „pinang": baposon; momangan „sirih pruimen”: mongkomea'i; mongkan ,eten": monje'o; monginoem ,drinken”: mongga'oep; nioe ,kokos”: kolimboengo; mamba „heengaan”: memboeka; mamba $i$ hobo ,naar 't bosch gaan”: memboeka $i$ tano panas ,naar het warme land gaan": mamba $i$ winanga ,naar 't strand gaan”: memboeka $i$ kalangaa „naar de helderheid gaan; baboeno „lansat”: kamboeloloi; mantapa, ,iets boven het vuur rooken”: monsajo; montoedja ,rijststampen”: montoetoek; mongoendjang „,koken”: mohiis; ala mae "haal het hier": have mae naidjo (hawe is in sommige Toradjatalen ,,aankomen”; naidjo is „dat”); mongala ,halen”: mohawe; mingkot „op, afgedaan”: mahapoemo; tilon ,kalk”: teoela of aboe (teoela is in Poso „kalk”; apoe is ,asch”) B., pongaboe'i L.; alang "rijstschuur": peta (peta is in Poso een broednest voor hoenders); sagin ,pisang": loka (in verschillende talen van Midden Celebes ,pisang”); pongkoemit ,rijstsnijmesje”: kalapini; mindii ,,baden”: cminsosop; matemo "dood": nate'omo; ale of bonde ,rijstveld": 
hombola B., takap L.; djalan „weg”: kodjan; malisa „Spaansche peper”: kosehon; boeaa ,krokodil”: sampolangkai; boko' „schildpad”: pintisan; ikan ,visch": loobang; kela ,cassave”: bakat oe kaoe ,boomwortels": sampoeloe „tien”: santakap; sa'atoe „honderd”: mineete; takilon "mandje”, dat de voorgangster bij het oogsten om het middel draagt: telenon; tompoeson „stapel rijst": poloempoeng; mongkolon ,,iets op den rug dragen in een mand": mensadik; baoe ,varken": ponjamiti. Met dit ponjamiti worden alle dieren die in het bosch leven aangeduid, dus ook de gemsbuffel, cuscus enz.

Er zullen natuurlijk wel meer woorden zijn in de oogsttaal, maar de meeste woorden uit de dagelijksche taal worden ook bij het oogsten gebruikt. Enkele woorden hebben in de oogsttaal geen synoniemen, en mogen in dien tijd heelemaal niet worden uitgesproken. Dit zijn: kosi „Colocasia”, en tolobian „Lagenaria vulgaris”. Dit moet in verband staan met de rivaliteit, die tusschen het oude en het nieuwe voedsel gedacht wordt te bestaan.

Men beweert, dat men nu en dan een rijstplant vindt, wier stengel gesplitst is. In den voet van zoo'n plant, zegt men, bevindt zich altijd een bezoarsteen (kilooe, in Poso kilowoe). Er wordt dan eerst wierook (kamangian) bij de plant ontstoken; dan wordt ze uitgetrokken en de steen er uit gehaald (de wierook waarvan hier sprake is, is de hars uit de bast van den kamangian-boom, die een zoete lucht verspreidt, als ze wordt aangestoken). Men legt den steen in een kom met water en deze plaatst men bij de okoeman in het midden van het veld. Zulke steenen worden beschouwd als de geconcentreerde levenskracht van de rijst, die het gewas rijkelijk vrucht doet dragen. De voorgangster bij het oogsten heeft meestal ook een of twee van die steenen in haar mandje (takilon), dat ze om het middel draagt. Wanneer men den steen niet naar de voorschriften behandelt, loopt hij weg, verdwijnt.

Zij die bij het snijden van de rijst komen helpen, mogen daarmee niet eindigen, of zich ergens elders heen begeven, voordat het heele veld is afgeoogst. Het loon is één zeer groote bos rijst per dag, of twee gewone bossen ( 1 bos is santimpa), of een mand (basoeng) vol met rijst zonder steel, die men niet bij elkaar heeft kunnen binden. Zulke rijst zonder steel heet koentoep of kajantapnjo.

Als men nog rijst van het vorige jaar over heeft, kookt men voorloopig niet van de nieuwe rijst, maar men oogst het heele veld eerst af. Heeft men echter geen rijst meer over, dan mag men op den tweeden dag van het snijden van de nieuwe rijst nemen, en die 
stampen en koken. Als men de nieuwe rijst voor de eerste maal stampt, moeten enkele regels in acht genomen worden : bij het wannën wordt het kaf op een mat opgevangen; dit wordt in een boomblad gepakt en aan een stok opgehangen, die bij het rijstblok in den grond is geplant. Ook mag men niet met de vingers in de rijst, die op de wan ligt, roeren om te zien of er nog ongepelde korrels onder zijn, en die er dan uit lichten; men mag wel gepelde korrels van de wan nemen, maar geen ongepelde.

Als de nieuwe rijst gekookt is, vermengt men ze met kippevleesch, en maakt er een pakje van in imoang-blad gewikkeld; dit zijn harige bladeren (de haren moeten vermoedelijk zorgen, dat de kracht niet uit dit voedsel, waarvan men voor de eerste maal gebruikt, wegtrekt). Met dit pakje tikt men een kind op den rechterkant van den mond, en zegt daarbij: Tinoenda mae, noe mian, madi'-mo osazve; oelas oe tinaoemtoemaoen, aia sinawemo na oelas noe toemaoemtinaoem, toka santempo osaze ahe na oclas sidoe-sidoetoe, sa'am pokodaka, ladje sambatoe molompo'no. „De booze woorden (vervloeking) van menschen hebben geen uitwerking meer door het werk van vader en moeder; dit heeft uitwerking gehad, wat door vader en moeder is gedaan; het geluk wordt groot, en dan wordt men van één korrel rijst al dik". Met het werk van vader en moeder wordt het akkerwerk bedoeld. De zin is niet goed weer te geven, maar de bedoeling is, dat men door het eten van deze rijst gezond en krachtig zal worderi, zoodat zelfs het eten van een enkele korrel al verzadigt.

$\mathrm{Na}$ het uitspreken van deze woorden moet het kind van de rijst eten. De gewoonte die men bij andere stammen op Midden Celebes vindt, dat aan de huistrap, den haard, het droogrek, het stampblok en andere deelen van het huis wat van de nieuwe rijst wordt meegedeeld, kennen de Loinangs niet. Dit eten van de nieuwe rijst gaat met een feestje gepaard. Dit noemt men monsawe, hetzelfde sazwe, dat in de formule wordt gebruikt; het beteekent eigenlijk ,er bovenop brengen", het doel bereiken, uitwerking hebben. Als dit eten van de nieuwe rijst plaats heeft, nadat het heele veld is afgeoogst, noodigt men er ook wel anderen bij uit. In het Baloasche komen de akkergenooten bij den leider (tanaas) samen op den tweeden dag, dat hij aan het oogsten is; zoo doet men ook bij zijn beide assistenten, de pembebc'i en den pahemata, en vervolgens bij de overige leden van de gemeenschap. Een eigenlijk oogstfeest kennen de Loinangs dus niet.

Inmiddels heeft men de rijstschuur in orde gemaakt. Dit is een 
hut op 4 palen. ${ }^{1}$ ) Eens zag ik in het dorp Tombongan een schuur op 1 paal. De palen zijn van boven voorzien van ronde planken (dompong) om de muizen het binnenklimmen te beletten. Soms heeft men in de plaats van planken de bladscheede van den sago-palm om de palen gebonden; zulke dingen heeten soeda (in Pose heeten de muizenplanken toeda). Bij de Lingketeng-clan worden van de rijst, die den eersten dag gesneden is, 4 kleine bossen gemaakt, en deze worden midden op den vloer van de schuur gelegd. Daarbij wordt het mandje met oogstmedicijn geplaatst, dat de voorgangster om het middel heeft gedragen, en waarin ze een bos rijst heeft gezet. De andere bossen worden er om heen gerangschikt, en er bovenop gestapeld. Bij de Baloa-menschen worden de aren, die van de vier bijeengebonden rijststoelen zijn gesneden in de takilon (mandje met oogstmedicijn) gelegd. Hierop komt een groote bos rijst te liggen. Dit alles bij elkaar heet bengke-bengkele „oude vrouw” (in Poso bangkele of bongkolo). Om en op de bengke-bengkele komen de andere bossen te staan en te liggen. Wanneer de schuur gevuld is, mag men den eersten nacht de deur er van niet sluiten, en de trap niet weghalen. Is den volgenden morgen de schuur gesloten, dan mag men er gedurende de eerste dagen niet in. De Baloa-menschen wachten hiermee 4 of 8 dagen, waarna wierook wordt gebrand, voordat men enkele bossen van den stapel afneemt. In het Lingketengsche wacht men met het openen van de schuur totdat de rijstkorrels, die bij het binnendragen op den grond zijn gevallen, hoog zijn opgeschoten.

$\mathrm{Er}$ is geen bepaald lid van de familie aangewezen, die in de schuur mag komen; elk lid van het gezin mag er in, wanneer de huisvrouw hiertoe last geeft. Als iemand rijst wil koopen voordat de eigenaars de schuur uit zichzelf hebben geopend, moet hij vooraf een stuk ongebleekt katoen (balasoe) geven. Dit katoen heet pomboekai ,om te openen". Men kent geen vaten van gevlochten bamboe of van boombast om daarin rijst te bewaren. Wanneer iemand slechts een gering aantal bossen rijst heeft geoogst, bouwt hij een galerijtje aan de rijstschuur van een ander om daarop zijn voorraad te bewaren.

Alle Loinangs in het binnenland gebruiken het overeind staande rijstblok, dat nu eens de gedaante heeft van een beker, dan van een paddestoel. In het laatste geval is de voet of de, steel er van in den

1) Fig. 143 van Kaudern's I Celebes obygder II geeft een rijstschuur te zien in Pinapoean; om de palen zit de bladscheede van den sago-boom om de muizen te beletten naar binnen te klimmen. 
grond geplant. Zoo'n blok heet kalengkoe of oedja'an. Dicht bij het zeestrand heeft men de liggende rijstblokken overgenomen, die doelan-doelan heeten. De stamper heet aloe of pongoedja. Een wan die van pandan-bladeren gevlochten is, heet tapian. Is zij van repen bamboie gemaakt, dan noemt men haar kiapan. Verder gebruikt men nog bij het stampen van de rijst een wan met hoogeren rand, een soort van mand, die tembanan heet : daarin wordt het kaf van de rijst opgevangen.

Wanneer de oogst geheel mislukt, wordt dit toegeschreven aan een fout, die de leider, tanaas, moet hebben gemaakt. Hij wordt dan uit zijn ambt ontzet, en een ander wordt in zijn plaats gekozen.

\section{Oorlogvoren.}

Wanneer men de menschen de verhalen uit den ouden tijd hoort vertellen, zou men daaruit besluiten, dat de Loinangs voortdurend op voet van oorlog verkeerden. Wanneer men zijne akkers aanlegde, bleven de akkergemeenschappen zooveel mogelijk in elkaars buurt; om een of meer tuinhuizen werd een versterking aangebracht; op het minste gerucht van onraad trok men zich daar dan samen. De dorpen van de Lingketeng-clan hebben nimmer met elkaar gevochten, want alle zaken, die daartoe aanleiding zouden kunnen geven, werden door het Hoofd, den daka'njo, beslecht. Zoo ook hebben de menschen van de Baloa-clan nimmer onder elkaar gevochten.

De lieden van Linketeng en die van Baloa lagen echter voortdurend met elkaar overhoop, en veelal waren daartoe aanleiding geschillen bij het zoeken van damar. Aangezien het verzamelen van boomhars een werk van den lateren tijd is, moeten vroeger andere oorzaken tot de herhaalde krijgstochten aanleiding hebben gegeven. We mogen zelfs aannemen, dat het zoeken van dit boschprodukt eerder verbetering van den toestand heeft gebracht, omdat het in 't belang van de menschen was elkaar bij dit werk met rust te laten.

Elk jaar, vertelde men, gingen we met elkaar vechten, en elk jaar maakten we dan weer vrede.

Naar buiten trokken de Lingketeng-lieden gewoonlijk naar Boalemo om te snellen, en dan gingen ze tot Sioena toe. De Baloa-menschen gingen ook wel naar het Boalemosche, maar ze hadden hun vaste operatieveld onder de To Wana aan de Bongka-rivier. De To Wana kwamen op hun beurt geregeld bij de To Loinang wraak nemen. Een ter aanvoerders (talenga) van de Loinangs was Badili (misschien wel 
het Mal. bedil ,geweer"), die grooten naam maakte door zijn dapperheid. Hij sneuvelde in een gevecht tegen de lieden van Lingketeng.

Men deed mij eenige verhalen waaruit moest blijken, hoe dapper de Baloa-menschen waren. Ik deel daarvan één mede, omdat dit het oudste moet zijn. Het was in den heel ouden tijd, toen de stam nog te Lontojon samenwoonde. Op de plek waar nu het dorp Tamboenan staat, stonden toen acht huizen; die plek droeg den naam van Sabahang, dat ,onoverwinnelijk" moet beteekenen (sabahang zou hetzelfde kunnen zijn als sebarang, in den zin van ,het komt er niet op aan"). In dien tijd nu was een troep To Wana onder hun aanvoerder Lope ongemerkt het land binnengedrongen. Ze kwamen voorbij een tuinhuis, waar een kind hen opmerkte, maar niet wetende, dat het vijanden waren, vroeg het: „Waar gaat ge heen ?” De moeder herkende de vreemdelingen als vijanden, trok het kind naar zich toe en vluchtte er mee naar Sabahang. Daar ontstond een hevig gevecht, want slechts 8 Loinangs stonden hier tegenover 30 To Wana. Velen van de laatsten sneuvelden echter, en de rest begon terug te wijken, maar de aanvoerder Lope en een man die de tata'oemba salakati, een soort strijdhoed, droeg, hielden stand. Een man van Lontojon, die met Lope in gevecht was geraakt, hakte diens oor af. Lopé greep den ander bij de keel, en deze hield Lope's testes vast. Zoo vielen ze al worstelend op den grond. Lope lag boven, maar een man van Sabahang doodde hem. Drie To Wana waren nog overgebleven; dezen vluchtten het ravijn van de Loboe in. De lijken der verslagenen lagen op een hoop bijeen, en dit is de aanleiding geweest, dat het dorp voortaan Tamboenan ,stapel” werd genoemd. De verslagenen werden in een kuil begraven tusschen Baloa en Tamboenan.

De drie overlevenden staken de Loboe over en beklommen den aan den anderen oever gelegen berg. Al klimmende zagen ze de maan heel dicht bij zich, en ze meenden, dat als ze op den top waren gekomen haar wel met de hand zouden kunnen bereiken (kawe „naar iets reiken; betoe'on ,maan”). Vandaar dat die berg voortaan Kazean betoe'on ,waar naar de maan gereikt is", heet. Boven op den berg gekomen kookten ze rijstepap, en daar ze niets anders konden vinden om die pap op te doen, namen ze kooka-bladeren, die giftig zijn. Toen ze nu de pap met de vingers oplepelden naar den mond, gingen de vingers opzetten; toen ze de bladeren aflikten, zwelde ook de tong op, en alles deed hen pijn. Toen zeiden ze: „Wat is dat hier voor een land! Niet alleen de menschen zijn er dapper, maar zelfs het 
onkruid is er dapper, en valt ons aan!" Toen keerden ze naar hun woonplaats terug.

In het gebied van Lingketeng kwamen de To Wana niet. Hier had men meer last van menschen van Lembangan (dicht bij Pangimangan). Dezen zijn het ook geweest, die Pinapoean kwamen verbranden. Verder had men te lijden van invallen van Tobeloreezen, die zeeroof pleegden in de Tominibocht. Deze lieden kwamen tot dicht bij het dorp Salingan. De To Lage uit het Pososche strekten hun tochten niet ver in het binnenland uit, en hielden zich in de buurt van de monding van de Pokooehan.

Behalve de oorlogen met vijanden ging men er jaarlijks op uit om een of meer koppen te halen (mangae), wat noodig werd geacht om gezond te blijven, en om het gewas te doen gelukken. Alleen in het Lingketengsche ging men ook snellen, wanneer een hoofd (daka'njo of tonggol) of een lid van zijn familie was gestorven. Bij zoo'n gelegenheid stal men vaak een hoofd bij de Baloa-mensehen. Overigens ging men voor dit doel overal heen, waar het niet het gebied van den Sengadji van Kintom was. Men trok ook wel eens uit op bevel van pasgenoemden Sengadji om een dorp of streek te tuchtigen, die op de eene of andere wijze het ongenoegen van dezen potentaat had opgewekt.

De a a n o e rder in den strijd droeg den titel van talenga. Bij de Baloa-clan was de talenga tevens het hoofd van het dorp, zooals we gezien hebben, toen we over de bestuursinrichting van deze primitieve maatschappij spraken. De talenga heeft drie assistenten: de pondjolo, de pongkcali en de sega. Deze vier vormen samen een soort van raad, die over alle verschijnselen op het oorlogspad beraadslagen. De talenga is de voornaamste van hen; hij regelt den tocht, maar degeen die eigenlijk de teekenen waarneemt is de pondjolo. De pongkeali is een soort zendeling van den talenga, die aan de menschen eenig besluit overbrengt. De sega eindelijk is de representant van de krijgers, die meegaan; de laatsten heeten dan ook to sega-sega.

De talenga was een lid van het geslacht, waaruit steeds deze lieden gekozen werden. Tot zijne uitrusting behoorde een eigenaardige hoofdbedekking, die soealang heet. Dit is een soort tulband, een lap foeja, aan welks uiteinde franje is gesneden. Deze ineengedraaide lap wordt zoodanig om het hoofd gewikkeld, dat het einde met de franje aan de linkerzijde van het hoofd hangt. In dien hoofdband is een versiersel vastgemaakt, dat uit twee aan elkaar verbonden 
slagtanden var de babi roesa (een slagtand uit de boven-, en een uit de benedenkaak) bestaat. Soms draagt men twee van die tandversiersels op het hoofd, maar regel is één.

Naast die slagtanden gebruikt men ook de koelaloek; dit is een uit koper gegoten spiraal, die in Poso en in Mori sanggori heet. Deze spiralen zijn in den ouden tijd gekocht, en sedert hebben deze voorwerpen tot de erfstukken behoort. Deze sanggori zijn vermoedelijk door de To Mori gegoten, en waarschijnlijk heeft het pasgenoemde slagtandversiersel als voorbeeld gediend. Wanneer zoo'n koperen spiraal op het hoofd wordt bevestigd, gebruikt men daarbij een dubbel gevouwen band van foeja, die om het hoofd sluit, en waaraan de spiraal met een reep bont katoen wordt vastgebonden. Ook deze reep katoen eindigt in franje, die boven het linkeroor komt te liggen. Het doek of de foeja, waaraan de franjekwast (djamboenjo) hangt, heet kinini ,,de geelgemaakte”, omdat hij met curcuma geel gemaakt is. Een andere naam voor deze kwast is tinatakan.

Verder bestaat de uitrusting van den krijgsman in een zwaard (bangko'), speer (sosoedoek of talombo), en een schild (kanta). Dit laatste is $\operatorname{van}_{i}$ hout, versierd met schelpjes en haar. Het heeft denzelfden smallen vorm als de schilden, die bij de Toradja-stammen worden gebruikt, en die meer dienen om slagen te pareeren, dan om er zich mede te dekken; in het midden, waar aan de achterzijde het handvat is uitgesneden, is an de buitenzijde een dikken knobbel hout gelaten, om te voorkomen dat het schild op die plaats zou worden doorgehakt, en de hand gewond zou worden. ${ }^{1}$ )

In deze uitrusting hield men ook krijgsdansen, ocmapos, vooral ter eere van een voornaam bezoeker. Wanneer de radja van Banggai, die de tegenwoordige Zelfbestuurder van het Loinanggebied is, te Lembangan komt, gaan één oud strijder van Pinapoean, en één oud strijder van Tamboenan ook daarheen om hun vorst met spiegelgevechten te eeren:

Wanneer men er op uit zou gaan, trokken de talenga en zijn makkers en al degenen, die mee van de partij zouden zijn, naar een plek in het bosch. Daar werden een of meer hutten gemaakt om er den nacht in door te brengen. Verder bouwde de luitenant (pondjolo)

1) Van de uitrusting van den krijgsman heeft Dr. Kaudern in zijn I Celebes obygder II twee afbeeldingen gegeven : één in de reproductie van een schilderij tegenover. bl. 312 , en één in fig. 136, waar een man den krijgsdans uitvoert (oemapos). In fig. 131 vinden we een paar hoofdversierselen van babi roesa tanden, welk versiersel soealang heet; fig. 117 is een zwaard met de daarbij behoorende scheede, en fig. 118 geeft een schild te zien. 
cen tafeltje op vier pooten met een vloertje van bladstengels van den sagoboom, versierd met jong arenblad. Dit tafeltje, talaian geheeten, was naar het Oosten gericht, en daarop legde de pendjolo de volgende dingen: 2 bakjes (sochoe) van palmblad met gekookte rijst, waarop vleesch is gelegd afkomstig van een hoen, dat men bij die gelegenheid heeft geslacht. Verder twee bakjes met palmwijn (doeang) en 2 sigaretten, lopotan sosop; een pinangnoot, die in vieren gekloofd was, een in vieren gebroken sirihvrucht en 4 pruimpjes tabak. Bij de Lingketeng-clan gaf het hoofd, de tonggol, die sigaretten aan de strijders, maar bij het Baloa-volk zorgde de talenga er zelf voor. Ook werd bij dit offertafeltje een rek gemaakt, waarop de strijders hun kleeren hingen en waarbij ze hun speren plantten.

Wanneer de zon al laag stond; plaatste de luitenant (pondjolo) zich bij de offertafel, en hield deze vast. Rechts van hem stond de talenga, die de linkerhand op den rechterschouder van den pondjolo hield. Zoo deed ook de tweede assistent van den talenga, de pongkeali, bij den talenga, dan de sega en al de overige strijders. Dan riep de pondjolo: Kamoe sampoeoes, pia mae na kami mombamo mompatei mian; otimbang monsahoeba moeli' mae na kami, jo potoi mae noe ambolo, ambolo anoe maidek, metocdang noe pintoloen, ka otezva noe salebak maliana, ka otimbang kami locmadjango na kami, aia madi mansahoeba mae jo tipani na pintoloen, tiba salebak pokona mae noe timpaton, oeka malom. Potatai mae maliana na sa'angoe maka atina tanda pongala mami mae oebak moiton. „Gij sampoeoes (levenskracht, levensbeginsel); zie naar ons, die er op uit trekken om menschen te dooden; als gij merkt dat wij moeilijkheden zullen krijgen, laat ons dit dan weten door de voorteekens, leelijke voorteekens, laat het driemaal (herhaald geroep) hooren, en houd tegen het eenmaal (geluid geven) tegen het aanbreken van den dag. En als gij merkt,' dat ons die nu op reis willen gaan, geenerlei onheil zal treffen, laat dan niet het driemaal en het eenmaal klinken, maar laat (het vogelgeschreeuw dan) viermaal (herhaald) zijn, als de avond straks gevallen is. Spreek tegen het aanbreken van den morgen slechts eenmaal, want dat is het teeken, dat wij zwart hoofdhaar (de scalp) hierheen zullen brengen".

Het woord sampoooes zijn we al eens tegengekomen, en daar heb ik het weergegeven met ,levenskracht”. Maar de beteekenis van dit woord is veel uitgebreider. Het vogelgeschreeuw, dat aan de menschen voorspoed en geluk verzekert, heet ook sampoeocs; of misschien is het wel de kracht, die de menschen waarschuwt of aanmoedigt, die 
sampoeoes heet. In elk geval heet het viermaal herhaald vogelgeschreeuw in den voornacht, vereenigd met den enkelen kreet tegen den morgen sampoeoes, want deze combinatie verzekert den strijders, dat ze gezond en krachtig zullen blijven. Men gaat nog verder: de voorspoed, die door het vogelgeschreeuw is toegezegd, juister: vercorzaakt, wordt door de krijgers op het oorlogspad meegenomen, vastgehouden in de beide sigaretten, en die heeten nu ook sampoeoes. Sampoeoes is dus niet alleen wat de Maleiers semangat, en de Posoërs tanoana noemen, maar het is ook alles wat aan de semangat liracht geeft, en het voorwerp, dat die kracht vasthoudt of in zich bergt.

Wanneer de aanroeping heeft plaats gehad, trekt men zich in de hutten terug om te eten. $\mathrm{Na}$ afloop hiervan vermaakt men zich een poos lang met het houden van spiegelgevechten, en het uitstooten van den krijgskreet. Als het goed donker geworden is, gaat men weer in de hutten; somnigen gaan slapen, maar de meesten blijven waken om samen met den leider van de troep in spanning te luisteren naar de vogelkreten, die zich in de nachtelijke stilte zullen laten hooren.

De vogel die het meest in deze aangelegenheid heeft te zeggen, heet koekao; hij schreeuwt alleen 's nachts. Ik heb geen beschrijving van dezen vogel kunnen krijgen; men zei steeds, dat niemand hem ooit heeft gezien, want overdag verbergt hij zich; men zegt zelfs, dat mocht iemand den koekao te zien krijgen, deze mensch moet sterven. De meergenoemde Jakob van Tamboenan beweerde, dat de koekao veel gelijkenis zou hebben met een soort duif, die de Loinangs sapatooe zouden noemen (het is opmerkelijk dat zich hier eenzelfde geval voordoet als met den ouden naam van Tamboenan Sabarang ,het komt er niet op aan", want sapataoc doet sterk denken aan het Maleische siapa tahoe "wie zou het weten", namelijk hoe de koekao cr uit ziet. ${ }^{1}$ ) De Baloa-menschen hebben zich overigens weinig met den koekao ingelaten, want er is in het langst bewoonde deel van dit distrikt weinig zwaar bosch meer, en aangezien de vogel zich alleen in oerwoud ophoudt, had men ver van het dorp weg moeten gaan om naar zijn geroep te luisteren.

De vogel heeft zijn naam gekregen naar de kreet die hij slaakt. Als hij juist viermaal achtereen koekao! laat hooren (dit noemt men

1) In verband hiermee is een mededeeling van Dr. J. M. Elshout in zijn „De Kenja-Dajaks uit het Apo-Kajan-gebied”, bl. 497 van belang, waar hij over den vogel oewak spreekt, waarvan hij niets naders kan mededeelen, omdat de Dajaks zelf hem niet of zelden schijnen te zien. 
pimpaton) dan beteekent dat geluk en voorspoed, en dit geluid heet sampoeoes. Driemaal (pintoloen) en éénmaal (santaa of salebak) is hoogst ongunstig; over andere combinaties zal ik maar niet uitweiden.

Men onderscheidt ook nog de richting, vanwaar het geluid komt. Laat de koekao zich driemaal hooren aan den kant waar de vijand woont, dan geldt dit ongunstige teeken den vijand: deze zal tegenspoed hebben en nadeel lijden.

Als tweede in beteekenis onder de omineuze vogels geldt de uil, $k o e ̀ k$, waarvan ik al het een en ander heb meegedeeld in verband met den landbouw. Wanneer de uil roept : kokokokoc̀k! heet dit laoentako momposopan; dit is heel goed. Roept hij alleen kokoko! zonder den hreet met koèk te besluiten, dan heet dit laoentako djoemondjoho ide zin dezer woorden ben ik niet te weten gekomen); dit is minder goed; wordt dit kokoko! op verschillende toonhoogten uitgestooten, dan heet het kololook; dit voorzegt, dat er een rechtzaak van belang op handen is. Maar wanneer de vogel kikiki! laat hooren, zal men sterven. Van vogelgeluid in het algemeen dat goed voorspelt, zegt men momansin; kwaadvoorspellend vogelgeschreeuw heet poso.

Een derde nachtwogel welks geroep men beluistert, is de keketi; diens kreet is in alle gevallen onheilspellend, en daarom is het noodig, dat hij zwijgt, wil men met goede verwachting er op uit trekken. Laat deze vogel ten Oosten van het offertafeltje (talaian) zijn kreet hooren, dan zal het den heelen troep slecht vergaan; schreeuwt hij aan den Westkant er van, dan moet de luitenant, pondjolo, sneuvelen.

Het waarnemen van de vogelgeluiden heet 'mompihongoi ,iets beluisteren", of montindjohi. Na dit beluisteren der vogels moesten de mannen zich onthouden van allen omgang met vrouwen. Wanneer men den ganschen nacht niets goeds vernam, keerde men naar huis terug, en herhaalde de proefneming na 4 dagen nog eens. Waren de voorteekenen gunstig geweest, dan aten de krijgers het offer dat op het altaartje was gelegd, op, pruimden de daar angeboden sirihpinang; en de luitenant, pondjolo, maakte een doosje van sagobladscheede, waarin hij de beide sigaretten wegborg. De sampaeoes, het geluk, de voorspoed, is aan die sigaretten verbonden, en zoo werd de zegen op het oorlogspad meegenomen. Het doosje met de sigaretten bond de pondjolo zich met foeja onder den linkeroksel, en daarna mocht niemand meer links aan hem voorbijgaan.

Zoodra het goede vogelgeluid was waargenomen, maakte men dienzelfden dag alles voor den tocht gereed, en na drie dagen vertrok men om den volgenden nacht door te brengen op de plek, waar men 
de vogelkreten had beluisterd. Wanneer men den volgenden morgen van deze plek opbrak, deed de luitenant, pondjolo, eerst vier stappen in de richting, die men gaan wilde, en bleef daar staan; dan trok de heele troep hem aan zijn rechterzij voorbij; op den verderen tocht bleef de pondjolo altijd achteraan loopen.

De Hoofden bij de Lingketeng-clan (daka'njo en tonggol) namen nooit aan zoo'n tocht deel. Zoo ook bleef bij het Baloa-volk de mian kopian thuis.

Meisjes gaven aan de strijders tabak mede om die te pruimen, wanneer zij hun slag gingen slaan, ten einde daaruit moed te putten. De echtgenooten der krijgers moesten er zich voor wachten om gedurende de afwezigheid der mannen te twisten, de kinderen te slaan; ze mochten overdag niet slapen, en het vuur mocht niet uitgaan. Haar gedrag beinvloedde haar mannen, zoodat ze moesten meewerken om het welslagen van den tocht te bevorderen. Overigens was haar geenerlei arbeid verboden. .

Op weg zijnde sliep het geheele gezelschap, dat nooit groot was (meestal beneden de twintig) in één hut; de talenga kreeg daarin een plaats geheel vooraan, naar den kant van den vijand toe. De uil, $k a \grave{k}$, wees den weg in de wildernis aan. Men liep steeds in de richting, vanwaar men 's nachts het gekras van dezen vogel had vernomen; dit maakte dat men soms erg lang onderweg. was; alleen op de geluiden, die achter den troep werden vernomen, werd geen acht geslagen.

Overdag was het de:vogel koelis, waarop gelet werd: wanneer hij links of rechts van de krijgers zijn koelis! koelis! liet hooren, beduidde dit: Vooruit! vooruit! de :weg is veilig. Maar vloog hij vóór den troep over den weg, dan wilde de vogel daarmee te kennen geven: Gaat niet voort, want er dreigt iets op het pad!

Ook de toentoehoei, een soort arend, gaf den krijgers waarschuwingen: wanneer hij met den troep meevloog, leidde hij hen ter overwinning; maar vloog hij hen tegemoet, dan was dit een waarschuwing om niet verder te gaan. Men maakte dan dadelijk een hut om.er den nacht in door te brengen. Ditzelfde deed men ook, wanneer een slang het pad kruiste, en het gelukte den mannen niet haar te dooden. Gelukte dit wel, dan kon men gerust doorloopen. Zoo ook als men een boom hoorde vallen: gebeurde dit vóór den troep uit, dan moest men een nacht op die plek overblijven; hoorde men een boom achter zich omvallen, dan mocht men doorloopen, maar dan was men overtuigd, dat er iemand thuis was overleden. 


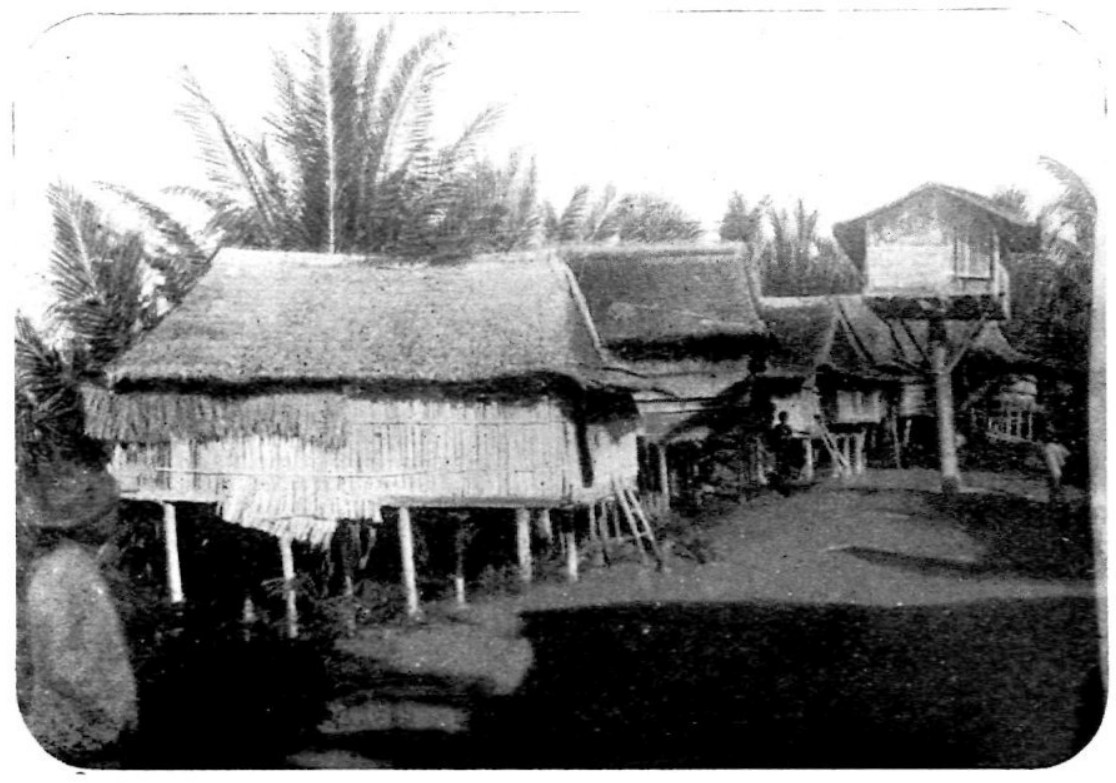

Het dorp Tombongan, een rijstschuur op één paal op het midden van den dorpsweg.

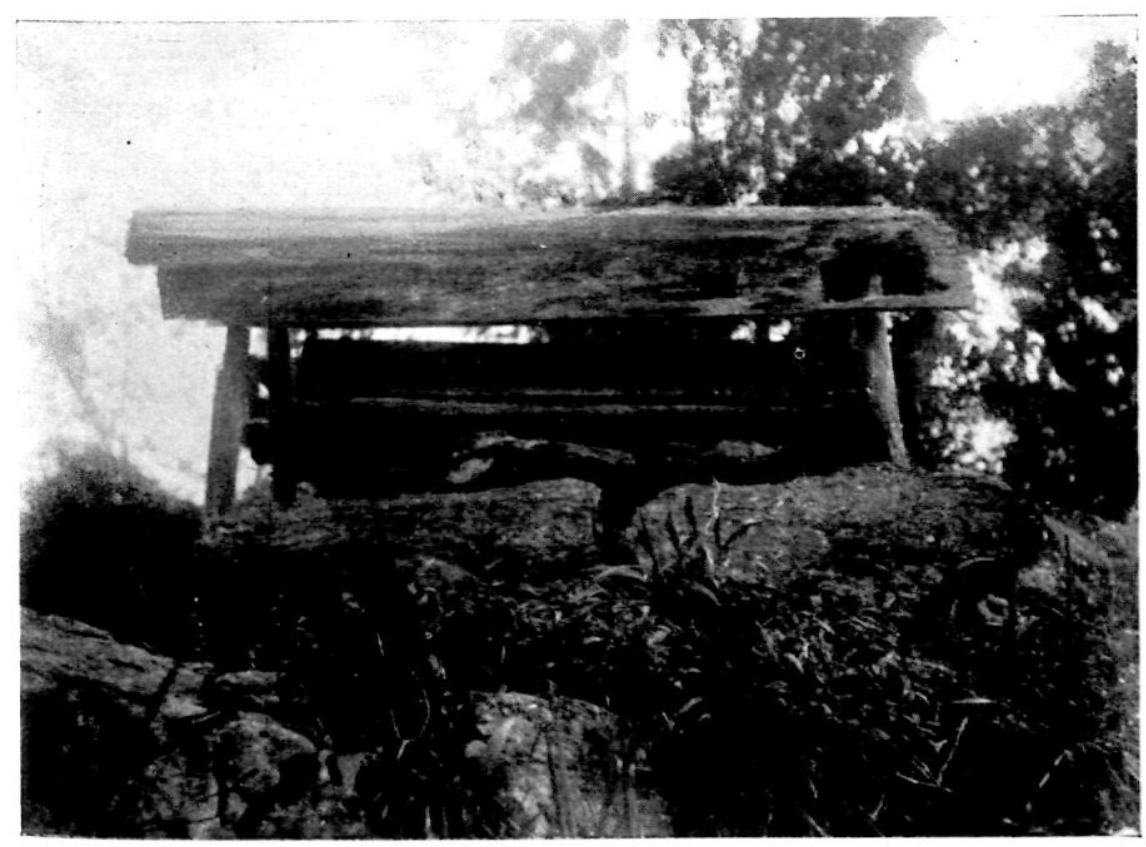

De lijkkist van Kamboa, staande op een rotspartij bij Lingketeng. 
Viel een boom om ter zijde van de strijders, dan had dit geen beteekenis.

Ook op droomen werd in zoo'n tijd nauwkeurig gelet. Wanneer bijvoorbeeld de aanvoerder, talenga, droomde, dat hij door een gemsbuffel werd aangevallen en door dit dier verwond werd, dan moest men net zoo lang op die plek blijven, tot een gunstiger droom den slechte had tenietgedaan. Doodde de aanvoerder in zijn droom het dier, dan beteekende dit groot geluk. Zag een der strijders zich in den droom een rivier overtrekken, en kwam daarbij een drijvende boomtak of iets dergelijks tegen hem aan, dan moest eerst een gunstiger teeken worden afgewacht, voordat men verder mocht gaan. Of als men al dicht bij het land van den vijand was, liet men den droomer achter om op de goederen te passen, terwijl de overigen cen aanval gingen doen. Wanneer men in den droom een kokos- of een pinangboom beklom en vruchten plukte, of als men in den droom een of ander ten geschenke ontving, mocht men er op rekenen veel voorspoed te hebben. Eenig teeken mocht nog zoo ongunstig zijn, teruggaan deed men nimmer; men had immers de sampoeoes, het geluk, de voorspoed, bij zich.

Was men dicht bij de plek gekomen, waar men zijn slag dacht te slaan, dan werden enkelen aangewezen om bij de goederen achter te blijven; hiervoor nam men de zwaksten. Twee van de vlugsten werden nu uitgezonden om den omtrek te verkennen. Dit heet montongkajan. Voorzichtig liepen de aangewezenen vooruit, met het zwaard vóór zich opgeheven in de hand om de lianen en takken, die hun weg versperden, onhoorbaar door te snijden. Hadden ze bijvoorbeeld een tuinhut ontdekt, waar menschen in waren, dan kwamen ze dit berichten, en men maakte zich gereed voor den aanval. Tegen het aanbreken van den morgen zette de luitenant, pondjolo, zich rustig neer, en nam de sigaretten, waaraan de sampoeoes gebonden was in de hand, samen met de gemberwortel, die door het hoofd aan de strijders was meegegeven. Hij blies op deze dingen, en sprak de strootjes toe: „Gij sampoeoes, houd de speren, zwaarden en geweren tegen, die ons willen treffen; maak ons onkwetsbaar. Gij sampocoes, ga daarheen naar den vijand, en maak zijn oogen blind, ontneem hem zijn kracht, opdat hij slap zij". Dan stapte de aanvoerder, talenga, over de sampoeoes heen, en na hem volgden de anderen; ieder kreeg een snipper van de gemberwortel te eten.

Zóó toegerust trok men in de morgenschemering er op uit om D1. 86. 
zijn slag te slaan: de talenga voorop, de pondjolo geheel achteraan. De eerste had zijn talisman, bakat (Mal. berkat) pangae, over den schouder hangen; deze talisman bestaat uit tanden van krokodillen en slangen, en uit verschillende wortels.

Degeen die een vijand verslagen had, hakte hem ook het hoofd af, dat in veiligheid werd gebracht. Dan pelde men de scalp (Link: kocliap, Baloa: kaliabang) er af, en deze werd op een rekje uitgespannen om spoedig te drogen. De hersens werden door het achterhoofdsgat uit den schedel verwijderd, en dan werd het skelet boven het vuur gerookt. Wanneer men meerdere vijanden verslagen had, werd gewoonlijk toch slechts het hoofd van één hunner meegenomen; meer dan 3 hoofden nam men nooit mee. De scalp werd door den luitenant, pondjolo, bewaard. De schedel werd met jong arenblad, taliti, versierd, en door een van de jongeren van den troep gedragen. Wanneer Lingketeng- en Baloa-menschen bij elkaar hadden gesneld, nam men vaak alleen een stukje vel uit den nek, of een paar vingerkoten van den verslagene mee om te voorkomen, dat de clangenooten zouden ontdekken, wie hun bloedverwant had gedood; een hoofd toch is moeielijk te verbergen voor de oogen van hen, die er op uitgaan om uit te vinden, waar dit is gebleven.

De t e rugke er. Wanneer de troep teruggekeerd was, maakte men halt op een punt in de buurt van het dorp. Daar hief men het krijgsgeschreeuw aan, mobagoha (Poso: mogoemora), en gilde den krijgskreet kahoe! kahoe! uit; voor elken verslagene gilt men éénmaal zijn vreugde uit: „De vrouwen der vijanden zijn weduwen 'geworden, zij bèweenen hare dooden!" Hierdoor kon men in het dorp dadelijk weten hoevelen men verslagen had. Daarna trok men in optocht het dorp binnen, waar men opgewacht werd door de inwoners, die zich intusschen netjes hadden aangedaan, en dadelijk tot het koken van spijzen waren overgegaan.

Men begaf zich rechtstreeks naar het huis van het Hoofd, tonggol, (ik vertel hier hoe het terugkeeren bij de Lingketeng-clan plaats had), en bleef aan den voet van de trap staan. De talenga had inmiddels het hoofd van den verslagen vijand overgenomen van dengeen, die het gedragen had; hiermee sloeg hij zoovele malen tegen den paal van het huis als er dooden gemaakt waren, en draaide den kop dan zoovele malen in de lucht rond als er lieden aan den tocht hadden deelgenomen. Vervolgens gaf hij het hoofd over aan den tonggol, die boven aan den trap stond, en die den volgenden zegen over de schare van dapperen uitsprak: Po'ochanna timbongan; po'oehanna 
maboehoe; po'ochanna mangkadjoe; po'oehanna toepehon; po'oehanna moendoen; po'ochanna toboeto; nokaocmoenakon; nokasipatakon; nokawadjitakon; nokabaniako; nokakabanakon. „Dat gij niet ontijdig sterven moogt; dat gij geen vrees kennet; dat gij niet onvoorspoedig moogt zijn op het oorlogspad; dat gij niet gewond wordet; dat ge niet moogt terugdeinzen; dat gij van niets de schadelijke inwerking moogt ondervinden; dat gij een hoogen ouderdom moogt bereiken; dat uw werk niet afgebroken worde; dat gij vaardig moogt zijn (in het afslaan van de aanvallen van den vijand); dat gij dapper moogt zijn; dat gij onkwetsbaar moogt zijn".

Dan werd de kop in een schaal gelegd, en het Hoofd (tonggol) ging in huis om een mooi baadje of een hoofdversiersel (soealang) te halen, dat hij aan den aanvoerder (talenga), die inmiddels naar boven was gekomen, schonk. Eerst daarna mocht de talenga zich neerzetten.

$\mathrm{Bij}$ de Baloa-clan had het volgende ceremonieel bij den terugkeer van een troep krijgers plaats: Wanneer de troep dicht bij huis gekomen was, maakte hij halt, en een paar der deelnemers aan den tocht werden vooruit gezonden naar het dorp om aan de achtergeblevenen kennis te geven, dat men was aangekomen. Ook hier was het krijgsgeschreeuw niet van de lucht. Gewoonlijk bleven de krijgers twee nachten op de plek, waar ze halt hadden gemaakt. Dan kleedden de dorpelingen zich mooi aan, mannen, vrouwen en kinderen, en trokken de dapperen tegemoet. $\mathrm{Bij}$ de ontmoeting werden spiegelgevechten gehouden. De gewoonte om hierbij op bamboe trompetten te blazen, zooals de Posoërs dit doen, kent men niet; wel blies men op Nautilus-schelpen (boeoet). Een oude van dagen sprak den luitenant, pondjolo, toe, en zeide: Toka tanaas, anoe mombebe'i, pahemata, pakita kinopikopian na mompoimboa to sega-sega, boele sangkoeka na notoa. „Hoe is het tanaas, pombebe' $i$ en pahemata, zijt ge allen in gezondheid weergekeerd met de strijders (to sega-sega), die ge hebt meegenomen, en ook hoevelen hebt gij gedood?" (We zien dus dat men hier de strijders toesprak, als waren het jagers die van de jacht terugkwamen, of als hadde men te doen met de leiders vari een akkercomplex).

De luitenant, pondjolo, antwoordde: Aitoc mboele kita anoe i lipoe mompokilarea ladjang mami, boctongki nopikopian, oele boele a sampoeloe notoea ka taoean a opat. „Daar zijt gij, die in het dorp zijt gebleven, vragende naar onzen tocht. Wat ons zelf aangaat, wij maken het best, tien zijn er gedood, en vier hebben we krijgsgevangen gemaakt". 
Vervolgens werd een spiegelgevecht gehouden, en dan sprak de oude weer: Kaloe kita binamiminsan nompedja oce Toili, mangka singkona balaniat monggalapakon oele aia sampocoes. „Wij zullen gezamenlijk de Toili-rivier betreden (in het gebied der To Wana), want wij ook zijn van plan om hoofden te gaan halen met de sampoeoes".

Dien nacht bracht men gezamenlijk door in de hutten op de rustplaats, waar een maaltijd werd gehouden, en men veel feestvreugde liedreef. Den volgenden morgen ging het naar het dorp; hier trad de mian kopian, de regelaar van de dorpsaangelegenheden, den troep tegemoet, en dan ontwikkelde zich een gesprek als pas is medegedeeld. Spiegelgevechten werden gehouden, en de mian kopian gaf aan de teruggekeerden de verzekering: „Al zijn wij in het dorp teruggebleven ,wanneer de vijand ons hadde aangevallen, dan zouden wij ons ook dapper hebben getoond".

De troep trok, in het dorp gekomen, eerst viermaal om het huis van den mian kopian, dan viermaal om dat van den anvoerder (talenga), en vervolgens even zooveel malen om dat van zijn luitenants en de andere deelnemers aan den tocht. Ten slotte hield men stil bij de trap van het huis van den pondjolo: het hoofd van den verslagen vijand met de franje van arenblad (taliti) werd onder een rijstschuur neergelegd. Boven aan de trap stond de vrouw van den pondjolo met het uiteinde van een langen ouden doek (kain patola) in de hand; deze doek werd over de trap uitgespreid. De vrouw sprak den pondjolo aldus toe: „Kom naar boven, sampoeoes; wees niet verlegen om boven te komen”. Dan zei de pondjolo: „Ga naar boven, sampoeoes, dit is vanzelfsprekend uw woonplaats". Dan klom de pondjolo met al de krijgsgevangenen vlak achter zich aan naar boven, terwijl zijn vrouw met enkele helpsters uit alle macht aan het doek trokken, als om degenen die het betraden, naar boven te trekken. Boven gekomen ging de pondjolo dadelijk met de krijgsgevangenen naar de salipi, het kamertje achter in de woning, waar de eigendomtnen van de familie worden bewaard, en daar zetten ze zich neer, terwijl de vrouwen en de overige aanwezigen krijgsdansen uitvoerden. Aan de krijgsgevangenen werden koperen schalen met rijst en kippevleesch voorgezet. Ook de andere lieden werden onthaald, en er heerschte groote vreugde. De mian kopian kwam daar als gast; het feest ging niet van hem uit. Dit maakt een groot verschil met de Lingketeng-lieden, waar alle regelingen van het Hoofd, den tonggol, tiitgingen. 
$\mathrm{Na}$ het koppensnellersfeest, mompasok, waarover straks meer; werden de krijgsgevavngenen aan den mian kopian overgegeven. Bij de Baloa-clan was het bij deze gelegenheid, dat de mian kopian aan den luitenant (pondjolo) een speer en een baadje schonk. Dit Hoofd bracht de krijgsgevangenen dan naar zijn heer, den sengadji (bosanjo) van Tangkian. Zoo bracht ook het Hoofd der Lingketengclan, de daka'njo, zijn krijgsgevangenen naar den sengadji (bosanjo) van Kintom. De krijgsaanvoerder (talenga), die het Hoofd hierbij vergezelde, ontving dan van den sengadji een speer, een zwaard en een baadje. Bij de Baloa-clan, waar de talenga tevens als volkshoofd werd beschouwd, stelde de sengadji van Tangkian een nieuwen functionaris aan, als de oude overleden was, of zich om de eene of andere reden had teruggetrokken.

Wanneer men een menschenhoofd was gaan halen voor een overledene uit. de hoofdenfamilie, werd het hoofd naar het graf van den doode gebracht, en daar op een staak aan het hoofdeneinde geplaatst. Men hield wat spiegelgevechten en stootte eenige malen den krijgskreet uit, en daarmede was de zaak afgeloopen. Had men meer dan één hoofd meegebracht, dan werden de overige bij de graven van andere dooden geplaatst, maar de familie van den overledene, aan wien deze eer bewezen was, moest dan aan den aanvoerder van den troep een geschenk geven.

Vier dagen na den terugkeer der strijders in het dorp had het koppensnellersfeest plaats. Bij de Lingketeng-clan kwam men hiertoe samen in de woning van het Hoofd, den tonggol; bij de Baloamenschen in de woning van den pondjolo. Wat beide feesten gemeen hadden, was, dat er een groote maaltijd werd aangericht, waartoe allen hun bijdrage gaven. Verder vermaakten zich de mannen den heelen dag en nacht met het uitvoeren van een soort dans, moseili geheeten, waarbij gezongen wordt. Elke strofe van dezen zang vangt aan met jaja-lele. Ieder danst op zichzelf met langzame bewegingen in de rondte draaiende, en elk oogenblik met den voet op den vloet stampende.

Op dit feest had het slaan tot ridder van de dapperen plaats, en deze plechtigheid verschilde bij de beide clans. Degeen die een vijand had neergestooten of neergeslagen ontving van den tonggol een speer of een baadje, een hoofdversiersel (soealang). Het baadje was van een soort stof, die sakalati heet, en dit kleedingstuk was het eenige uiterlijke teeken voor een dapperen man bij de Lingketeng-clan, omdat anderen geen kleeren van deze stof mochten dragen. Meestal 
was de aanvoerder zelf de gelukkige, die deze onderscheiding ontving, omdat hij vooropgaande steeds het eerst met den vijand in aanraking kwam. Maar nu en dan was het ook een to sega-sega, een soldaat, die den eersten vijand had gedood. Het hoofd (tonggol) slachtte ook een hoen, en met het bloed van dezen vogel smeerde hij voorhoofd en tong van den gelukkige aan, opdat diens dapperheid zou toenemen. Ook werden hem bij den maaltijd de pooten en de vlerken van het hoen als toespijs voorgezet.

Bij de Baloa-clan hield men er nog verschillende rangen op na. Degeen, die op den tocht voor de eerste maal een vijand gedood had, mocht een hoofddoek dragen, die met curcuma (kini) geel gemaakt was. Zoo'n hoofddoek heette tomboeloon. Hij werd door de echtgenoote van den krijger gemaakt, en op het koppensnellersfeest (mompasok) naar het hus van den pondjolo gebracht. Deze liet dan den doek door iemand, die zijn sporen in den strijd al verdiend had, den geridderde op het hoofd zetten. Had men voor de tweede maal een vijand gedood, dan had men het recht om de kinini ,de geelgemaakte” te dragen. Deze doek zag er bijna evenzoo uit als de pas genoemde, maar aan het uiteinde waren franjes gesneden (we hebben boven reeds gezien, dat met zoo'n doek de babiroesa-tanden van de soealang op het hoofd werden gebonden). Had dezelfde dan weer geluk gehad, dan mocht hij de varkenstanden in den hoofddoek dragen, de soealang. Nog een rang hooger en hij mocht de soealang met twee paar slagtanden dragen. Maar dit was ook het hoogste dat hij bereiken kon. Doodde hij daarna weer een vijand, dan begon hij van voren af aan met de tomboeloon.

De Baloa-lieden hadden nog een ander onderscheidingsteeken, waarvan ik bij de lieden in 't Lingketengsche niet vernomen heb, en ik verzuimde er opzettelijk onderzoek naar te doen. Dit is de bantoejan. $\mathrm{Hij}$ bestaat uit een stokje, waaraan het haar van een verslagen vijand gebonden is. Om stokje en haar is een koord gewonden; het aantal windingen geeft het aantal vijanden aan, dat de drager er van heeft verslagen. Deze bantoejan droeg de krijger aan het snoer met talismans, dat hij over de borst had hangen. Maar hij verborg het steeds voor vreemde oogen door er zijn draagsarong over te plooien.

Boven vertelde ik dat het meegebrachte menschenhoofd bij de Lingketeng-clan dadelijk na de aankomst van de troep door den aanvoerder (talenga) in het huis van het Hoofd (tonggol) werd gebracht. Bij die gelegenheid bracht hij daar ook binnen een jonge arentak, waarvan de bladeren aan repen waren gescheurd, en ver- 
volgens omgeknikt; aan de op deze wijze klaargemaakte tak, taliti genoemd, was een stukje van de scalp gebonden. Deze tak met scalp werd door den talenga boven in het dak van het tonggol-huis bevestigd.

Bij de Baloa-lieden had het bovenbrengen van het hoofd pas plaats na afloop van het koppensnellersfeest (mompasok). Dan haalde een oud man den kop van onder de rijstschuur, waar men hem zoo lang had opgehangen, weg. Hij stootte hem eenige malen tegen een plank, die op de trap van het huis van den luitenant (pondjolo) was gelegd; en sprak daarbij: Momoentoen taliti aia, liasakon na akoe paha, liasakon toempo ohoboeno; isa, doea, toloe, opat, lambakonnjo akoe langkai. „Ik stoot deze arenbladeren (waarmede de kop versierd is) (tegen de trap), opdat ik niet blind moge worden, opdat ik niet onverwacht moge sterven; $1,2,3,4$, totdat ik een oud man moge geworden zijn".

Daarna reikte hij den kop over aan een vrouw, die in huis stond; deze voerde er een krijgsdans mee uit, en daarna werd het hoofd midden aan den zolderbalk opgehangen. Vervolgens werd de scalp onder de deelnemers aan den tocht verdeeld; dezen voegden wat jong arenblad (taliti) aan het hun toebedeelde stukje toe, en brachten het zoo naar het graf van een overleden bloedverwant, waar ze het aan de grafhut ophingen.

Vervolgens had bij beide clans nog plaats het mompolapas sampoeoes ,het loslaten van het geluk” (of den voorspoed, welke aan de beide sigaretten was verbonden, die door den pondjolo onder den linkeroksel werden gedragen). Vier tot tien lieden gingen daartoe onder veel vreugdebetoon en met voortdurend uitvoeren van krijgsdansen en spiegelgevechten naar het bosch, en zochten daar een waringin-boom (mocnoc') uit. Dezen gaven ze 7 kepen boven elkaar in de bast; in de onderste keep klemde men de beide sigaretten, waarbij de luitenant (pondjolo) aldus sprak: „Hier moet gij inklimmen, sampoeoes, en als wij weder gaan vechten, dan moet ge u laten hooren, en ons kennis geven, of we er op uit kunnen gaan of niet."

Wanneer een clangenoot was gesneuveld, werd hij bij de Baloamenschen zonder kist begraven; of men den gedoode in het bezit van zijn hoofd had gelaten of niet, kwam, er niet op aan. Bij de Lingketeng-clan werd de gesneuvelde als elke andere doode begraven, maar men mocht voor hem het doodenfeest niet vieren dan aleer men zijn dood had gewroken. Het hoofd van een verslagene, dat men naar huis bracht, werd dan op het graf in den grond gestopt. 
Ik heb reeds met een enkel woord gezegd, dat wanneer de beide clans een poos lang met elkaar hadden geschermutseld en er aan beide kanten enkele dooden waren gevallen, men vrede sloot. Op den afgesproken dag ging dan een aantal mian kopian, dorpsregelaars, van de Baloa-clan naar Lingketeng, naar de woning van den daka'njo. Aan beide zijden had zich veel volk verzameld, dat zich bezighield met spiegelgevechten en krijgsdansen te houden. Dan volgde een groote maaltijd, waarbij de balakat (magische kracht) van den toemondo (sultan) van Kintom en Tangkian, soms zelfs de balakat van Soeltan Talinate, werden aangeroepen, om te verzekeren, dat welke van de beide partijen zou beginnen met het plegen van vijandelijke daden, door de aangeroepen balakat zou worden "gegeten”, d.w.z. dat hij op geheimzinnige wijze te gronde zou gaan, of allerlei rampen zou ondervinden. Maar - voegde mijn zegsman, de daka'njo, nu kapitan van het Loboe-gebied, er bij — niet lang na dit vredesluiten was het weer mis, want de menschen van Baloa waren erg slecht!

$\mathrm{H} \mathrm{uw} \mathrm{elij} \mathrm{k.}$

Voor beide clans geldt dezelfde regel wat betreft de familie-verhouding, waarin man en vrouw tot elkaar staan om met elkaar te mogen trouwen of niet. Broerskinderen mogen met elkaar huwen, zoo ook zusterskinderen; kinderen van broer en zuster alleen dan, wanneer de broer een dochter en de zuster een zoon heeft; heeft de eerste een zoon en de tweede een dochter, dan kunnen deze twee nimmer een paar worden. Zelfs zoolang het nog bekend is, dat grootvader en grootmoeder, of overgrootvader en overgrootmoeder in die verhouding tot elkaar gestaan hebben, mag het paar niet met elkaar huwen. Als men zich hieraan niet stoorde, dan molioe, d.w.z. de aarde zou instorten, het zou voortdurend regenen, aardschuivingen zouden plaats hebben, in één woord er zou een natuurramp plaats vinden. Pas lieden uit het vierde geslacht mogen er aan denken zich met elkaar te verbinden, en dit mag dan nog alleen met mongkojo'i.

Voor het mongkojo' $i$ is een priester noodig. De man brengt hem een haan, de vrouw een kip. Beide vogels worden door den priester gedood; het bloed van den haan strijkt hij op het voorhoofd van de vrouw, en dat van de kip smeert hij op het voorhoofd van den man. Daarbij spreekt hij: „,Ik mongkojo'i u, opdat er geen natuurramp zal plaats vinden, opdat uwe kinderen niet zullen sterven, enz." Dan worden de hoendẹrs țoebẹręiḍ: dẹ man krijgt dẹ beide 
pooten van de kip, en de vrouw die van den haan te eten. Ook wordt een kokosnoot in tweeën gedeeld, met het vleesch waarvan beiden zich het hoofdhaar moeten reinigen. Men laat hierbij niets in het water afdrijven.

Wanneer ouder en kind, of broer en zuster het met elkaar hielden, werden beiden gedood door ophangen, segot ka oelajo-oelajo ,in de lucht ophangen", noemde men dit; ook wanneer een oom zich met een nicht, of een tante zich met een neef afgaf, werden beiden gedood. Was de familieverhouding wat verder verwijderd, dan kon het molioe, het plaats hebben van een natuurramp, voorkomen worden door het betalen van 50 blokken ongebleekt katoen (balasoe), waarbij het Hoofd (tonggol bij de Lingketeng-clan, mian kopian bij het Baloa-volk) de balakat van den stamvader aanriep om mogelijke rampen, die uit deze verbintenis zouden kunnen voortkomen, af te wenden.

In het Lingketengsche is een huwelijk van twee broers met twee zusters geoorloofd. In Baloa mag dit ook, maar dan moet degeen, die het laatst huwt, aan zijn reeds gehuwden broer oetoen betalen, anders zouden zijne kinderen ziekelijk zijn, of spoedig sterven. Deze octoen bestaat altijd uit een stoel sagoboomen, omdat sagoboomen koud zijn. Ditzelfde moet ook worden gegeven, wanneer iemands broer trouwt met een tantezegster van diens vrouw.

Wat men graag ziet, is, als iemand huwt met de zuster van zijn zwager, zoodat broer en zuster gehuwd zijn met zuster en broer. In Lingketeng noemt men dit monsoesoele'an lai ,tot elkaar wederkeeren" (monsoele is ,terugkeeren”), in Baloa montolosan ,met elkaar ruilen". Wanneer de ouders van zulke paren overleden zijn, blijft de bruidsschat gewoonlijk achterwege.

Een dubbelhuwelijk, mongohoea, kwam volgens het getuigenis der menschen in den ouden tijd weinig voor. Maar bij de Loinangs hebben we weer een voorbeeld, hoe vorsten de zeden bederven. Kamboa, wiens ziel nog steeds door de menschen wordt angeroepen, had zeven vrouwen, en het voorbeeld van deze Hoofden werd onder de menschen van Lingketeng veel gevolgd. Bij de Baloa-lieden moet het dubbelhuwelijk minder voorkomen. Wanneer de man een tweede vrouw er bij wilde nemen, moest hij daartoe de toestemming hebben van zijn eerste vrouw. Soms verzette deze zich hiertegen, maar dan trachtte de man haar door een geschenk tot toegeven te bewegen: hij gaf haar een stel oorknoppen (djaling), een mooie sirihdoos, een kain, en derg.; zoo'n geschenk heet pontambo „om in den steek te 
laten" (haar verzet). Soms zoekt een gehuwde vrouw een tweede echtgenoote voor haar man, bijvoorbeeld als zij kinderloos is, en ze bang is, dat haar man er op een goeden dag toch toe over zal gaan; dan maar liever een vrouw van haar eigen keuze, dan eene met wie de man voor den dag zou komen, en met wie ze het niet zou kunnen vinden. Dat een man met twee zusters tegelijk gehuwd zou zijn, wordt wel is waar niet met bloedschande gelijk gesteld, maar de clangenooten voelden zich over zoo iets beleedigd, en zoo iemand moest een boete van 4 blokken ongebleekt katoen (balasoe) aan zijn Hoofd betalen.

Het aanzoek van de familie van den trouwlustige naar de hand van een meisje heeft bij beide clans een eenigszins verschillend verloop, al blijkt de eenheid weer uit de gelijkheid van de namen der geschenken, die worden gewisseld. Wanneer in het Lingketengsche een jongeling het oog op een meisje heeft laten vallen, tracht hij haar 's nachts te bezoeken. Wil het meisje den jongen niet, dan stuurt ze hem weg; mag ze hem lijden, dan staat ze toe, dat hij bij haar blijft slapen. Dit heet mondolong. Hij zorgt er echter voor, dat niemand in dat huis iets van zijn bezoeken merkt, en vóór het aanbreken van den dag is hij weer verdwenen. Wanneer dit eenigen tijd geduurd heeft, geeft de jongeling aan zijn' vader kennis, dat hij met dat meisje wil trouwen. De vader of een oom van den jongen begeeft zich dan naar de ouders van het meisje om te mompokilawa ,een verzoek te doen". Hij zegt dat hij een kuiken op dat erf heeft gezien, dat hij graag zou opvoeden. Bij deze gelegenheid geeft hij ook de pongoosi, het zetten van een merkteeken om aan anderen te kennen te geven, dat iets besproken is, een eigenaar heeft. Dit is gewoonlijk een ring van koper of uit schelp gebikt (boeso heet een armband van schelp); bovendien een lap katoen, posoeoeon, waarvan de jongeling verwacht, dat het meisje hem een broek of een baadje zal naaien. De ouders van het meisje zeggen dan, dat de familie over het aanzoek zal beraadslagen. Regel is, dat de beslissing niet langer dan 4 dagen mag worden aangehouden.

Wanneer het aanzoek is aangenomen, spreekt de jongeling van dohoikoe ,mijn verloofde” (modohoi ,een verloofde hebben”; indohoi „verloofd zijn”; saloealenjo ,zijn geliefde”; mosaloeale ,liefhebben”). Tien of twintig dagen nadat het aanzoek is aangenomen, gaat de familie van den jongeling een sirihdoos aan de ouders van het meisje brengen; dit heet mantoean; daarbij wordt ook besproken, motoon, dat men over vier dagen bijeen zal komen om over den bruidsschat, 
$k o \ddot{e}$, te spreken. Dit bespreken van den bruidsschat heet molato. Eerst wanneer de bruidsschat bijeen is, kan het huwelijk plaats hebben.

Ook in het Baloasche tracht de jongeling zich eerst van de genegenheid van het meisje te overtuigen. Wil het meisje hem, dan geeft hij haar geschenken, pongoosi, om te voorkomen, dat een ander haar zal vragen. Eertijds bestond dit geschenk in een motombing, een onbruikbaar weefsel, waarover reeds gesproken is; tegenwoordig geeft men in de plaats daarvan een fraaien zakdoek. Verder een blikken doosje met een spiegeltje er in, een salak, kam uit hout gesneden (een kam die gemaakt is van de bladnerven -olis- van den sago, die in een bamboetje zijn bevestigd, en door een vlechtsel van garen aan elkaar verbonden zijn, heet sisi, Mal. sisir) en een armband, die door handelaren worden ingevoerd, en die hier den naam dragen van maladjan.

De huwelijkskandidaat brengt aan zijne aanstaande schoonouders sirih en pinang, maar bij dit bezoek spreekt hij nog niet over zijn voornemen; vaak vertelt hij er voorloopig ook niets van aan zijne ouders, totdat dezen zelf merken, dat er iets aan de hand is, en hem vragen op welk meisje hij het oog heeft laten vallen. Dan maken de ouders van den jongen de sindoea of pagawe klaar; dit is een sirihdoos met toebehooren, waaraan zijn toegevoegd: 1 stuk kain (lipa sangkolong), een armband van schelp (boeso santida), een ring van zilver (sinsing oeansila), een motombing (motombing sa'angoe), een baadje (badjoenjo sa'angoe), een slendang (salecnjo sa'angoe), een mes (pisonjo samata). Dit geschenk heet mantoean, en het wordt na voorafgaande waarschuwing door een oom van den jongeling naar de ouders van het meisje gebracht. De oom zegt dan ongeveer hetzelfde als in het Lingketengsche: „Wij zijn gekomen om een kip te zoeken, misschien hebt gij nog een kuiken (koto hodo)". De andere partij antwoordt: Timbali, het kan gebeuren", maar wij vragen een paar dagen den tijd om de kip te ondervragen, en dan zenden we u bericht". Het meisje wordt gevraagd of ze met den jongen wil trouwen. Wil ze niet, dan gaat het huwelijk niet door, al wenschen de ouders het. In dit geval zullen de laatsten trachten hun dochter over te halen om toe te geven, maar men dwingt haar niet om tegen haar zin te trouwen. Meestal antwoordt het meisje op de vraag harer ouders: "Ik weet niets te zeggen: als gij het wenscht, dan wil ik ook". Dan wordt aan de familie van den jongeling meegedeeld, dat het aanzoek is aangenomen.

Tijdens de verloving gaat de jongen zijn aanstaande schoonouders 
bij allerlei gelegenheden helpen. Als er iets op den akker van de ouders van haar verloofde te doen is, verleent het meisje daarbij haar diensten. Deze verloving duurt soms een jaar, want het huwelijk kan niet worden voltrokken, voordat de bruidsschat bijeen is. Gedurende dezen tijd gaat de jongeling telkens 's nachts bij zijn verloofde slapen.

Wanneer het meisje zich, nadat de pongoosi gegeven is, misdraagt, wordt alleen dit geschenk teruggegeven, en volgt nog geen boete. Maar trekt het meisje zich terug na het overreiken van de mantocan, dan heeft zij. ook nog 1 of 2 blokken katoen (balasoe) te betalen. Deze boete heet pangoetang,,schuld” of pongapin ,inwikkelaar”, waarschijnl. om er de gewisselde teekenen van de trouwbelofte in op te bergen.

Gaat het huwelijk niet door omdat het meisje zich misdragen heeft, clan moet ook de man, met wien ze het gehouden heeft, de pangacetang betalen. Voordat men het ongebleekt katoen kende, werden alle boeten in aarden borden, lean, betaald. Een blok balasoe geldt voor 15 borden.

Hetgeen de jongeling bij zijn huwelijk aan zijne schoonouders moet geven, bestaat uit twee deelen: de koë en de patakon. De eerste is de eigenlijke bruidsschat. In het Baloa-distrikt was deze eertijds gewoonlijk 1 stuk ongebleekt katoen (balaose), en in het Lingketengsche gewoonlijk 4 stukken. Toen ik er mijne verwondering over te kennen gaf, dat de bruidsschat zoo laag was, zei een oude man: „Vroeger was een blok balasoe moeielijk te krijgen; men moest lang werken, voordat men genoeg aan damar en bijenwas bij mekaar had om 1 blok (dat een handelswaarde had van $f 2$ of $f 2.50$ ), te kunnen koopen". In het Lingketengsche bedraagt de bruidsschat tegenwoordig al gemiddeld $\mathrm{f} 150$.

Tot de patakon behoort alles wat ooms en tantes en andere familieleden van het meisje eischen, als vergoeding voor ware en vermeende diensten, die vroeger aan de bruid zijn bewezen. Daartoe behoort in de eerste plaats de pantana noe soesoe, de vergoeding die aan de moeder van de bruid wordt gegeven voor het zoogen van haar kind. Dit is gewoonlijk een koperen schaal (doelang). Andere familieleden van de bruid vragen een hakmes, een sirihdoos, een kain, en derg. Op deze eischen mag men afdingen, maar zijn ze eens vastgesteld, dan moet de jongeling soms maanden lang er op uit om alles bij elkaar te zoeken.

De aanstaande schoonvader van zijn kant gaat met zijn naaste verwanten geruimen tijd op de jacht om het gemsbuffelvleesch bij 
elkaar te brengen, dat noodig is voor de bruiloft. Als een vast tegengeschenk geeft de bruid vier bamboes met gedroogd onoeang-vleesch aan de ouders van haar aanstaanden man. Dit geschenk heet tawa.

Huwen heet moosoa. Het feest van de huwelijkssluiting heet van de zijde van den man momboa ,geleiden", n.l. van den bruidegom; van den kant van de vrouw spreekt men van pompopea ,wachten”, n.l. op den bruidegom die gebracht wordt. We zullen de gewoonten in deze weer van elke clan afzonderlijk behandelen. Bij de Lingketeng-menschen heeft het geleiden van den bruidegom in den namiddag om een uur of 5 plaats. De bruidegom draagt een mand, $b a k i$, op den rug, waarin een mes, een kain en een sirihdoos liggen. De stoet, die uit een groot aantal menschen bestaat, familie en vrienden van den bruidegom, wordt voorafgegaan door een oud man, liefst een krijgsaanvoerder (talenga). Onderweg heft men voortdurend gejuich aan, dat mohagai heet. Bij het huis van de bruid gekomen, houdt de stoet stil; de vader van de bruid komt dan naar beneden en legt een zwaard op den grond neer, waarop de bruidegom gaat staan. Dan legt de aanstaande schoonvader zijn rechterhand op het hoofd van den bruidegom, en zegent hem met de woorden: Mompolibamo $i$ Anoe i booenenjo $i$ Anoe, liasakon na singgaatan, liasakon na timbongan enz. volgen dezelfde wenschen, als het Hoofd uitspreekt over teruggekeerde krijgers. „Om N.N. (naam van den bruidegom) op te doen klimmen tot zijne vrouw N.N. (volgt de naam van de bruid), dat ze niet van elkaar mogen scheiden, dat ze niet een kort leven mogen hebben, enz." Als men daarna de trap opklimt, moet de bruidegom er voor zorgen den rechtervoet er het eerst op te zetten.

In huis gekomen gaat de bruidegom zitten op het verhoogde deel vóór in de woning, en plaatst de mand, die hij gedragen heeft, vóór zich; de bewoners van het huis en de gasten zetten er zich om heen. Dan wordt de bruid geroepen, die zich zoo lang verborgen gehouden heeft in het kamertje (salipi) achter in het huis. Ze gaat tegenover den bruidegom zitten met de mand tusschen hen in. Beiden houden de mand met de rechterhand vast, en dan zegent het Hoofd (tonggol) hen in, met ongeveer de volgende woorden: „Ik trouw N.N. met N.N., dat ze niet van elkaar zullen scheiden, dat ze niet ontijdig mogen sterven, enz.", dan volgen weer de wenschen, die ik reeds eenige malen heb opgegeven. $\mathrm{Na}$ het uitspreken van dezen zegen laten beiden de mand los, geven elkaar de hand, en zeggen: Salamat nika lahen „Geluk met een helder (zuiver) huwelijk”. Dan neemt de 
bruid de mand mee naar binnen en bergt die op, nadat haar vader eerst de voorwerpen, die zich daarin bevinden, er uit genomen heeft.

$\mathrm{Nu}$ wordt de maaltijd opgediend. Iedere geleider van den bruidegom krijgt een kippepoot als toespijs bij zijn rijst; bovendien ontvangt elke vrouw, die den bruidegom heeft gebracht, nog een halven vadem ongebleekt katoen, en de mannen een hoofddoek (singgang); dit katoen wordt over de schaal of het bakje met gerechten heen gespreid. De familie van de bruid moet wel goed toezien, dat alles in orde is, want de gasten zijn er bij deze gelegenheid op uit om aanmerkingen te maken, en de gastheeren voor tekortkomingen te beboeten. Heeft men bijvoorbeeld vergeten een bakje met toespijs te vullen, of vindt een gast een stukje pinangschil op zijn schaal met spijzen, dan verwijdert hij zich beleedigd, en beboet de feestgevers.

Wanneer allen hun deel vóór zich hebben staan, neemt een der gastheeren het woord: dit heet momasor of basiloloa. Hij zegt: A kita totoetoeoema, pisieka-soekapmo mae, pa soehoe singgi-songgiling pa kanan tigo, pa koelap noe popos, pa soehoe oea lapis; boli fake koelang, madi maala ototonggolakon, pa sinangkalinga. „O gij heeren, doet (de bakjes of schalen met eten) open (d.i. licht er de lap katoen, die het bedekt af), misschien staat er een bakje (van pisang- of palmblad) scheef, misschien is er wat tabak op, of een pinangschil, of staan twee bakjes in elkaar (waarvan dus één niet gevuld is); neemt dit dan niet kwalijk, men heeft dit niet met opzet gedaan, misschien heeft men verkeerd gezien (zich verkeken)".

Op deze toespraak antwoordt een der gasten: „Gastheeren, gij l,ehoeft niets te zeggen, als het niet de.dorpsregeling ware (zoo te doen); al mocht het zijn dat we een pinangschil of een paar bakjes in mekaar aantroffen, we nemen dit niet kwalijk, wanneer slechts onze eensgezindheid krachtig blijft".

$\mathrm{Na}$ afloop van den maaltijd wordt het jonge paar ,de les gelezen”. Dit doet gewoonlijk het Hoofd (tonggol). Hij zegt bijvoorbeeld : „A1 zijt gij pas één dag bij elkaar, en een uwer krijgt een wond, of wordt ziek, dan moet de ander hem (haar) goed verplegen; en als de een den ander slaat, doe dit dan niet midden op den weg, maar doe het in huis, als de een werkelijk verkeerd heeft gedaan. Als de vrouw verkeerd doet en zich met een anderen man afgeeft, zullen alle goederen naar den man terugkeeren. Als de man naar een andere vrouw loopt, zullen de goederen (bij echtscheiding) niet naar den man teruggaan. Gij moet uwe wederzijdsche ouders helpen; en als gij een of ander voordeel hebt (b.v. jachtbuit) moet ge daarvan aan 
uwe ouders mededeelen". De nacht wordt verder doorgebracht met allerlei spelen en dansen.

In het Baloasche gaat het sluiten van een huwelijk eenigszins anders, al zijn de hoofdlijnen dezelfde. Ook hier verzamelen zich vrienden en kennissen in het huis van den bruidegom. Ieder hunner brengt iets mee als bijdrage in de te maken kosten, veelal een aarden bord (lean) per man. De bruidsschat (het stuk balasoe, dat door den vader van den bruidegom is gegeven, en dat afzonderlijk in een regenmatje - tindoeng - is gewikkeld) de pantana noe soesoe en andere geschenken voor de ooms en tantes van de bruid (waarvoor de ooms van den bruidegom hebben gezorgd), worden alle in een mand (baki) gepakt, die in den optocht wordt meegedragen. Men eet vooraf in het huis van den bruidegom, en daarna wordt de stoet opgesteld, met het Hoofd, den mian kopian, voorop, en zóó trekt men om een uur of 5 in den namiddag naar de woning van de bruid.

Bij de trap gekomen houdt men stil, en roept de mian kopian naar l,oven het doel waarvoor men hier is gekomen, nl. om een paar te trouwen. Dan roept iemand uit de woning: „Blijft daar niet staan, maar komt boven; de trap is wel niet mooi, maar komt hier zitten".

Dan gaat men naar boven, maar een aantal familieleden van de bruid heeft de toegang verspert, mongomboni sabatang. Ieder eischt wat van de binnenkomenden, voordat men hen den weg vrijlaat. In den ouden tijd werden de meermalen genoemde weefsels, motombing, en borden gegeven om doorgelaten te worden. Binnen getreden wordt de mand met den bruidsschat en bijbehoorende dingen in het midden van de ontvangkamer gezet, en allen zetten zich neer.

De bruid heeft een aantal makkers, jongens en meisjes, verzameld, die elk met een sirihdoos, die men in soorten heeft als sakoepa, kabila, mantoean, gewapend zijn. Die doozen zijn gevuld met pinangnoten, en aan elken voornamen gast wordt zoo'n doos aangeboden. Deze neemt er de noten uit, en legt er iets anders, vroeger meestal een motombing-weefsel, voor in de plaats. Dit heet mohangkati (verg. Mal. angkat „oplichten, 'opnemen”).

Daarna wordt het eten opgedragen en heeft de maaltijd plaats. Dat is om een uur of 8 in den avond afgeloopen, en dan wordt de mand, waarin de bruidsschat met de bijgeschenken, naar binnen in het woonvertrek (soeo') gebracht, waar de inhoud er uit wordt gehaald en opengemaakt; alles wordt nauwkeurig onderzocht of een en ander wel in overeenstemming met de afspraak aanwezig is. Heeft men 
zich hiervan overtuigd, dan laat men alles aan het Hoofd en de voorname gasten zien.

$\mathrm{Nu}$ worden bruid en bruidegom geroepen; ze gaan tegenover elkaar zitten, en dan spreekt het Hoofd (mian kopian) het paar toe. Eerst richt hij zich tot den bruidegom: „Gij krijgt nu N.N. tot vrouw, en ge moogt niet minachtend spreken (motaap odjole) van hare ouders”. Dan tot de bruid: „Gij hebt nu N.N. tot echtgenoot, die honderd blokken katoen (dit wordt zoo maar gezegd, want in werkelijkheid is de bruidsschat slechts één blok) als bruidsschat voor $\mathrm{u}$ heeft gegeven, wat geen kleinigheid is, en dit alles zult ge terug moeten geven, als ge hem wegwerpt (van hem scheidt)". Weer tot den man: „Gij hebt alles en alles bij elkaar wel 150 blokken katoen onkosten gehad (al zijn het er maar 2 of 3, bruidsschat met de bijbehoorende geschenken); dit alles zijt ge kwijt, als ge uwe vrouw weggooit (van haar scheidt). Als ge op jacht zijt geweest, moet ge niet alleen uw eigen ouders een deel van het wild geven, maar ge moet ook uwe schoonouders bedenken”. Weer tot de vrouw: „Als gij buitenshuis gaat eten, zonder uw man, doe dit dan niet bij een eigen broer of zuster (dit wordt beschouwd als een teeken, dat de vrouw van haar man af wil, een begin van wegloopen), maar ga dan eten bij een familielid van uw man".

Vervolgens spreekt het Hoofd de menigte aan en zegt: „Nu weet gij allen, dat N.N. de vrouw is van N.N.; als iemand haar benadert, mag hij overhoop gestoken worden, en niemand zal naar hem om kijken (men noemt dit nohadja ka hambaoe ,door een buffel vertreden", zoodat hij niet gewroken wordt; ik herinner er aan dat de Loinangs geen buffels hebben). Ieder weet nu dat N.N. de man is van N.N.; wanneer een vrouw hem verleidt, mag zij doodgestoken worden, zonder dat iemand haar zal wreken. Hebt gij allen het gehoord ?”. Eenigen uit de aanwezigen roepen: „Nog niet!” Dan herhaalt het Hoofd alles wat hij heeft gezegd en vraagt weer : „Hebt gij het gehoord?” Weer antwoordt men: „Nog niet”. Als hij dan deze vraag nog eens doet na voor de derde maal zijn mededeeling te hebben herhaald, weer ten antwoord krijgt: „Nog niet!” zegt hij alles voor de vierde keer, en dan roepen alle aanwezigen: „Ik heb het gehoord!" en dan volgt er een gejoel en geschreeuw van belang, waarbij meermalen de krijgskreet wordt uitgegild.

Als het rumoer tot bedaren is gekomen, neemt de mian kopian de rechterhand van den bruidegom, en legt daarin een klaargemaakte sirihpruim; hierbij zegt hij hem nog eens, dat N.N. nu zijn vrouw 
is, en dat hij haar op alle mogelijke wijzen moet helpen. Dan pruimt de bruidegom de sirih-pinang, waarbij hij al het opgewekte speeksel moet inslikken, niets mag hij uitspuwen. Zoo doet het Hoofd ook bij de bruid. De meergenoemde mand, die de bruidegom meebrengt, wordt bij de Baloa-clan niet door het bruidspaar vastgehouden. $\mathrm{Na}$ afloop van dit pruimen geeft de bruidegom het Hoofd en den aanzienlijken gasten en den familieleden van de bruid de hand, en ditzelfde doet de bruid bij de familieleden van den bruidegom. Hiermee is de plechtigheid afgeloopen.

Het behoeft nauwelijks opgemerkt te worden, dat de huwelijksvoltrekking van een lid van het daka'njo- of van een tonggol- geslacht in het Lingketengsche met bizonderen luister wordt voltrokken. Wanneer een man uit het volk met een meisje uit een tonggol-geslacht wilde huwen, moest hij eerst ,zijn aanzien (grootheid) koopen”, inongoli kadaka'an. Hij deed dit door het geven van een slaaf, die in den ouden tijd een waarde vertegenwoordigde van 50 blokken ongebleekt katoen (balasoe). Dan kwam nog de bruidsschat, die uit den aard der zaak anmerkelijk hooger was dan de gewone reeds genoemde bedragen voor het volk. Deze bestond uit allerlei katoenen goederen. Verder koperen borden, koperen waterketels, speren, een pamaki, d.i. een zwaard met zilveren scheede. Alles te zamen werd deze bruidsschat op een waarde van 100 blokken katoen gewaardeerd (dus ongeveer $f$ 250). Ook deze bruidsschat moest geheel worden voldaan op den dag, waarop het huwelijk plaats had. Dit werd op dezelfde wijze gesloten als boven beschreven is door het vasthouden van de mand (baki).

Bij de Lingketeng-clan gaan vier dagen na het huwelijk man en vrouw naar het huis van de ouders van den eerste. Dit heet monsoeieakon ,doen terugkeeren”; het gaat met een plechtigheid gepaard. De vader van den bruidegom gaat naar beneden wanneer de stoet is aangekomen, legt een zwaard op den grond, waarop de bruid gaat staan en dan zegent hij haar op dezelfde wijze als de vader van de vrouw het den bruidegom heeft gedaan. In huis gekomen ontvangt de jonge vrouw een koperen bord (doclang) ten geschenke, dat den naam van pomboeat ,oplader” draagt, en dat de bedoeling heeft om haar over te halen naar boven te gaan. Elk van hare geleiders krijgt !ij den daarop volgenden maaltijd een kippepoot als toespijs, maar de schaal met eten wordt niet met een lap katoen toegedekt, zooals bij den maaltijd tijdens de huwelijkssluiting. Het jonge paar blijft dan een jaar bij de ouders van den man wonen, in welken tijd het D1. 86. 
de ouders van beide kanten helpt bij het akkerwerk. Wederzijdse ouders zorgen gedurende dit jaar voor het eten van het jonge paar. $\mathrm{Na}$ afloop van genoemden tijd bouwt het nieuwe gezin zich een eigen woning in het dorp van den man. Groote huizen, waarin een aantal gezinnen bij elkaar wonen, heeft men bij geen van beide clans gekend.

Bij de Baloa-menschen heeft het tegenbezoek aan de ouders van den man reeds plaats in den namiddag volgende op den huwelijksdag. Zoo eenigszins mogelijk trekt de familie van de vrouw bij deze gelegenheid een levenden gemsbuffel (onocang) met zich mee als geschenk, benevens rijst en toespijs. Zoodra de jonge vrouw de trap van het huis op wil gaan, komt haar schoonvader naar beneden en trekt haar aan haar hand naar boven. In huis gekomen doet hij haar een zilveren armband (poto) om. Dan zetten allen zich neer om sirih te kauwen, en spoedig daarop volgt de maaltijd. Wanneer de bruidsschat niet hoog is geweest, keert het jonge paar na twee dagen reeds terug naar het huis van de vrouw. Is de bruidsschat groot geweest, clan brengt het een langen tijd in de woning van den man door. Gaat het er toe over een eigen huis te bouwen, dan doet het dit in het dorp van den man.

Zoowel schoonouders als schoonkinderen heeten monian. De broers en zusters van de vrouw (van den man) zijn de dawok van den man (van de vrouw). De echtgenooten van die broers en zusters zijn zijn (haar) andalan. De schoonzoon mag in eerbied voor zijn schoonouders in niets te kort schieten. In de eerste plaats behoort daartoe, dat hij hun namen niet mag noemen. Hij mag de slaapplaats zijner schoonouders niet betreden; hij mag geen sirih-pinang uit de doos zijner schoonouders nemen; alleen als zij hem iets daaruit toereiken, mag hij dit pruimen. Wanneer hij dit alles niet in acht namen, zou hieruit balaa over hem komen, een toestand, waarin niets van hetgeen bij deed, zou gelukken; wat hij plant zou niet opkomen, of mislukken; op zijne tochten zou hij geenerlei voorspoed hebben. Wanneer de vrouw zich niet behoorlijk tegenover hare schoonouders gedraagt, zou de balaa zich daarin uiten, dat haar kind niet geboren kan worden. Soms roept iemand de balaa af over zijn schoonzoon of schoondochter; hij spreekt dan een vloek over hem of haar uit, terwijl hij het gelaat gericht houdt naar de opgaande of ondergaande zon. Deze vervloeking zal dan na zijn dood in vervulling gaan.

Wanneer iemand zonder opzet tekortgekomen is in eerbied tegenover een zijner schoonouders, kan de balaa, die over hem dreigt te 
komen, worden afgewend: de schoonvader wascht dan de handen in water of in palmwijn, en van dat vocht drinkt de schoonzoon.

Wanneer een kind oneerbiedig tegenover vader of moeder is, treft hem geen balaa, maar boeto, een geheimzinnige macht, die het lichaam aantast: het kind gaat sukkelen, zoodat van zwakte "het lijfje” (tompos) uitzakt; bij een jongen openbaart zich boeto ook in het lang worden van den penis.

Van alles wat als bruidsschat en bijgeschenken aan de ouders van de vrouw gegeven is, mag het jonge paar niets gebruiken. Is er bijvoorbeeld gemsbuffelvleesch mee gekocht, dan mag het paar daarvan niet eten, anders podoso' $i$, het wordt hen tot schuld aangerekend; ze zouden allerlei puistjes en ontstekingen op de huid krijgen; ze zouden geheel en al onder de luizen geraken.

$\mathrm{Bij}$ beide clans worden ongehuwden angetroffen. Men vertelde van een paar lieden ,wier uitrusting niet voldoende was”, waarmee bedoeld wordt, dat de geslachtsdeelen niet ontwikkeld waren, hermaphrodieten dus. De reden waarom anderen ongehuwd blijven, is hun leelijkheid, die het andere geslacht terugstoot. Enkelen vertoonen ook een afkeer van het huwelijk waarvan men geen verklaring weet te geven.

$\mathrm{Echts} \mathrm{ch}$ eiding. Wanneer een echtpaar wilde scheiden, werd de zaak door het Hoofd, de notabelen en de familie onderzocht en besproken. Soms is de aanleiding tot het verzoek om echtscheiding, dat man of vrouw motaap odjolie, onbehoorlijke woorden heeft geuit ten opzichte van de schoonouders. Men tracht den vrede dan te herstellen door den beleedigden schoonouders een geschenk aan te bieden. Wanneer de reden is, omdat de man zijn vrouw heeft geslagen, dan maakt hij de zaak weer goed met een geschenk, dat pontambo heet, een kain of een armband. Moeielijker is de zaak, wanneer een van de twee een afkeer van de ander heeft gekregen. Wanneer degeen, die den afkeer heeft opgevat, bij zijn eisch om te scheiden blijft, moet hij (zij) het gelag betalen. Gaat de zaak van den man uit, dan moet hij uit zijn huis trekken met achterlating van al zijne goederen, zelfs van zijn baadje en zijn hakmes. Wil de vrouw niets meer van den man weten, dan moet zij de gemeenschap. pelijke woning verlaten met achterlating van alle goederen; ook de bruidsschat moet zij vergoeden.

Dat de vrouw een afkeer krijgt van den man is meestal een gevolg van de omstandigheid, dat ze haar hart aan een anderen man verloren heeft. Als de echtgenoot eenig vermoeden heeft op een ander 
man, die hem zijn vrouw zou hebben ontvreemd, dan spreekt hij wel eens een bedreiging uit bij de scheiding; zoo'n bedreiging heeft palapalangan. Hij zegt dan: „Wanneer mijn gescheiden vrouw trouwt met iemand van dien kant van het dorp (waarbij hij in de richting wijst van de woning waar de verdachte woont), dan dood ik ze beiden". Hij zorgt er voor, dat alle dorpsgenooten zijne woorden hooren. Wanneer men dan in den ouden tijd aan zulk een bedreiging uitvoering gaf, werd dit als iets vanzelfsprekends beschouwd, en de moordenaar werd niet gestraft. Eens had een mijner zegslieden te Tamboenan zoo iets bijgewoond. De gescheiden echtgenoot zag eens zijn voormalige vrouw met den man, dien hij in zijn pala-palangan had aangewezen, samen naar het water gaan. Hij bond toen alle dingen die als bruidsschat teruggegeven waren tot een pak bijeen, en volgde de twee. Aan het water doodde hij ze beiden. Thuisgekomen wierp hij den bruidsschat naar buiten, en riep het Hoofd en de notabelen om naar de verslagenen te gaan kijken. Allen legden zich bij het gebeurde neer. De ouders van de gedoode vrouw namen den bruidsschat weer tot zich.

Wanneer de man zonder voorkennis van zijne vrouw den nacht bij een andere vrouw doorbrengt, kan dit als een reden tot echtscheiding gelden, waarbij het recht geheel aan den kant van de echtgenoote is. Meestal echter weet de man zijn beleedigde echtgenoote tevreden te stellen door een geschenk. Heeft een echtscheiding met wederzijdsch goedvinden plaats, zonder dat er een bepaalde aanleiding toe is, dan worden de bezittingen in twee gelijke deelen verdeeld, en gaat men uit elkaar. In zoo'n geval laat de man zijn woning aan de vrouw, tenzij zij er de voorkeur aan geeft naar hare ouders terug te keeren.

De echtscheiding wordt uitgesproken door het Hoofd (in Lingketeng de tonggol, in Baloa de mian kopian). Het Hoofd deelt een pinangnoot en een sirihvrucht in tweeën, en steekt de beiden helften in den mond van den man en in die van de vrouw, waarbij hij zegt: „Van heden afaan zijt gij niet meer gehuwd; als de vrouw een anderen man wil nemen, en de man een andere vrouw, kunt gij uw gang gaan". Deze handeling heet mosilaakon pomangon. Bij de Baloa-menschen wist men er niet van, dat de mian kopian hiervoor eenig loon zou ontvangen; maar in Lingketeng was het gewoonte, dat de man van de aan hem teruggegeven huwelijksgoederen (in geval de scheiding van de vrouw was uitgegaan) een deel aan den tonggol gaf. Wanneer b.v. de teruggegeven goederen een waarde vertegen- 
woordigden van 15 blokken katoen (balasoe), dan kreeg de tonggol er 5 van. Als de vrouw alle bezittingen behield, dan gaf zij den tonggol voor zijne beslissing een geschenk, dat den naam draagt van oedjoelaa of bonto-bontolan.

Wanneer een reeds gescheiden paar zich wil verzoenen, brengen zoowel de man als de vrouw een hoen en wat gepelde rijst aan het Hoofd, dat de echtscheiding heeft uitgesproken. Deze verklaart dan dat beiden weer een echtpaar zijn geworden. Als bij de scheiding de bruidsschat is teruggeven, moet de man deze weer ter beschikking stellen van zijne schoonouders. Is de man de oorzaak geweest van de scheiding, en wil de vrouw geen gehoor geven aan zijn wensch om weer samen te leven, dan gaat de man er wel eens toe over den bruidsschat voor de tweede maal te betalen om haar terug te krijgen.

Ove rs pe1. Wanneer een man bij eens anders vrouw komt, heet dit molosoki, of mombolosakon. In den ouden tijd mocht de overspeler gedood worden, tenzij hij naar den daka'njo of den mian kopian vluchtte, of het Hoofd er op andere wijze bijtijds tusschen kon komen. De boete die voor zulk een misdrijf betaald moest worden, werd $\mathrm{mij}$ heel verschillend opgegeven. In alle gevallen wordt eerst uitgemaakt, of de echtgenoot van de overspelige vrouw haar nog als echtgenoot wil handhaven of niet; zoo wordt ook aan de echtgenoote van den overspeligen man gevraagd, of zij bij haar schuldigen echtgenoot wil blijven of niet. Blijven ze bij elkaar, dan moet de overspelige vrouw in het Baloasche 50 blokken katoen (balasoe) geven aan de echtgenoote van den man, met wien ze overspel heeft gepleegd. In Lingketeng zou dit bedrag de helft van het genoemde antal blokken katoen zijn; in Pinapoean slechts 8 blokken; hoe dichter dus bij het zeestrand hoe minder. Ging het paar uit elkaar, dan moest de overspelige alle huwelijksgoederen en den bruidsschat aan den beleedigden echtgenoot uitleveren.

De overspeler moest in Baloa aan den beleedigden echtgenoot 70 blokken katoen uitbetalen, in Lingketeng en in Pinapoean slechts 8 . De Hoofden kregen hiervan weer een deel als belooning of oedjoe laa.

Wanneer een gehuwd man zonder toestemming van zijn vrouw het met een meisje houdt, heet dit molangkasakon ,er over heen stappen", n.l. over zijne wettige echtgenoote. Dan moest hij aan zijne echtgenoote 50 blokken katoen betalen om van haar te scheiden, en dan kon hij met het meisje trouwen. Alleen wanneer de echtgenoote er haar toestemming voor gaf, kon de man dat meisje als tweede vrouw nemen. De eerste vrouw werd dan de booene poe'oe ,,de echte 
vrouw". Dit gebeurde in den regel alleen dan, wanneer de man de toestemming zijner vrouw had gevraagd, voordat hij naar het meisje toeging.

Bij de Baloa-clan werd een misstap van een gehuwd man met een meisje lichter gestraft: de man gaf aan het Hoofd (mian kopian), dus aan de gemeenschap 3 tot 5 blokken katoen, terwijl het meisje er 4 moest geven aan de vrouw van den man, dien ze bij zich had toegelaten.

Wanneer een ongehuwd man een meisje zwanger had gemaakt, konden haar ouders net zooveel vragen als bruidsschat, als ze wilden; het stond dan aan den man of hij daarna het meisje wilde huwen of niet, maar de geeischte som moest hij betalen.

E rf recht. Bij de Lingketeng-clan krijgt een zoon tweemaal grooter deel van de erfenis dan de dochter. De verdeeling heeft altijd zóó plaats, dat de zoons het gereedschap, de wapens en de andere speciale bezittingen (als gongs en koperen borden) van den vader krijgen. Ook de woning valt meestal aan een hunner, veelal aan den oudsten zoon, ten deel. Alle aanplantingen als sagobosschen, kokosboomen en dergelijke vallen de dochters toe. Bij de Baloa-menschen werd mij gezegd, dat de zoons in het algemeen meer krijgen dan de dochters, ofschoon niet juist tweemaal zooveel. Het schijnt hier ook voor te komen, dat de oudste zoon het leeuwendeel ontvangt, en het overige gelijkelijk onder zoons en dochters wordt verdeeld; waarschijnlijk treedt de oudste zoon hier dan op als beheerder van het erfgoed.

\section{Zwangerschap en Geboorte.}

Behalve het reeds medegedeelde geval, dat een vrouw van een krokodil beviel (een verhaal dat waarschijnlijk van vreemdelingen is overgenomen), heb ik niets vernomen omtrent bizondere geboorten, dat een vrouw eenig dier, of eenig dier een mensch zou hebben ter wereld gebracht. Ook kende men geen verhalen, dat de mannen vroeger (b.v. in de kuit) zwanger werden. Tegen kinderloosheid kon men mij nergens eenig middel opgeven; alleen onderwerpt men zich wel eens aan een kuur, die een vreemdeling tegen een ruime vergoeding voorschrijft.

Voor ,zwanger zijn” kent men twee woorden: hompo en tianan; het eerste is een net woord; het tweede gebruikt men alleen, als men met minachting spreekt, b.v. wanneer een vrouw van een onecht kind zwanger is. Men schaamt zich voor dit laatste, en meestal tracht 
het meisje abortus op te wekken, voordat anderen den toestand waarin zij verkeert, hebben opgemerkt; want als men te weten kwam in den ouden tijd, dat een meisje of vrouw de vrucht afdreef, dan werd zij gedood door ophangen, want het opwekken van abortus veroorzaakte een natuurramp (mobioe).

Merkt men, dat een meisje zwanger is, dan ondervraagt het Hoofd haar naar den vader van het kind. Soms weigert zij halstarrig den naam te noemen van den man, die haar zwanger heeft gemaakt. In zulke gevallen steekt er altijd iets achter: dan is het een oom of een ander familielid geweest, met wien het houden van seksueele gemeenschap als bloedschande wordt beschouwd. Als het meisje haar verleider heeft genoemd, ontkent deze wel eens de vader te zijn. Ik heb reeds verteld, dat het Hoofd in zulk een geval het houden van een godsoordeel voorschreef in den ouden tijd; er moest in het water om gedoken worden. Als degeen die voor den man onderdook, het won, moest het meisje de boete betalen, die stond op het valsch beschuldigen van een persoon. Maar de gemeenschap vergat het geval niet, want in hun hart gelooft men in zulke gevallen de woorden van de vrouw. Wanneer het kind dan ter wereld was gekomen, en het was een paar jaar oud, dan keek ieder het scherp aan, en als men trekken in het gelaat van het kind opmerkte, die deden denken aan den man, die door zijn moeder als de vader was aangewezen, dan hielp geen ontkennen meer, en de man moest het bedrag van den bruidsschat betalen, of hij met de moeder van zijn kind huwde of niet. Bovendien moest hij nog 10 blokken katoen geven, waarvan 5 aan de familie van de vrouw, en 5 aan het Hoofd (de gemeenschap) kwamen; deze boete heet lioe ,natuurramp", omdat de man door het opwekken van zwangerschap buiten het huwelijk de natuur had getart om zich op ongewone wijze te openbaren.

Men ziet er niets beangstigends in als het kind op vader of moeder lijkt; men beschouwt dit blijkbaar als een natuurlijke zaak. Alleen wanneer de gelijkenis heel sterk is en aan ieder opvalt, maakt men zich wel eens ongerust, of dat kind misschien niet te veel van de levenskracht van vader of moeder heeft genomen, zoodat deze spoedig zal moeten sterven. Dan werd of wordt de priester geroepen; deze slacht met eenig ceremonieel een hoen, en smeert wat van het bloed op de voorhoofden van ouder en kind.

In de geboorte van tweelingen (hapi) ziet men niets bizonders, van welk geslacht de beide kinderen ook mogen zijn. Nimmer werd een van de twee gedood of aạn ęen fạmíliẹlịd tẹr opvoeding gegeven, 
Men beweert, dat van te voren te zien is of een vrouw tweelingen' met zich draagt, want dan zou over haar buik een streep of vouw loopen. Zoo zegt men ook, dat de vrouw een dochter ter wereld zal brengen, als haar gelaat bizonder bleek ziet; heeft ze last van bloedaandrang, zocdat haar gezicht vaak rood is, dan zal ze een zoon krijgen.

Wanneer bij herhaling een kind doodgeboren wordt, of kort na de geboorte sterft, wordt de priester er bij gehaald; deze spreekt met den boehake-geest, die gewoon is in hem af te dalen, en vraagt om een vloek, die mogelijk op de ouders rust, van hen af te nemen. Mij denkt hierbij in de eerste plaats aan een vervloeking van een der schoonouders, die het teleurgestelde echtpaar heeft getroffen. Dan wordt een maaltijd aangericht, die als een verzoeningsacte is bedoeld. De man geeft aan zijn schoonvader een kain, en zorgt dat hij bij den maaltijd een kippepoot als toespijs heeft. Zoo doet ook de vrouw ten opzichte van haar schoonvader. Daarna zegenen (mohondazvit; mompohondawiti, ,iets als zegen over iemand uitspreken") beiden hun schoonkinderen op de reeds enkele malen medegedeelde wijze. Het kind, dat daarna geboren zal worden, zal blijven leven, zegt men.

Als een ouderpaar alleen zoons heeft, of altijd maar dochters krijgt, verlangt het naar een dochter of een zoon; dan doet men een belofte (matindja), b.v.: „Wanneer ik nu een dochter (een zoon) krijg, dan zal ik een gemsbuffel (onoeang) slachten bij gelegenheid, dat het kind voor de eerste maal naar beneden wordt gebracht". Het kan ook zijn, dat een echtpaar altijd zoons krijgt, omdat de vader bij zijn huwelijk gezegd heeft: „Ik wil alleen jongens hebben”. Wil hij dan toch later wel eens een dochter hebben, dan moet hij aan zijn vrouw een geschenk geven, en haar vragen hem een dochter te geven. Helpt dit niet, dan moet hij zich bij de zaak neerleggen, want dan heejft Toempoe „Eigenaar” (van alles, dus God) het eenmaal zoo vastgesteld.

Is een vrouw zwanger, dan komt een priester bij haar; deze blaast op haar, en laat haar water drinken, waarop hij geblazen en waarover hij een tooverformule uitgesproken heeft. Dit moet dienen om alle booze geesten en kwade invloeden, die de vrucht kwaad zouden kunnen doen, te verdrijven.

Zooals bij alle andere Indonesische volken heeft ook de Loinangsche zwangere zich voor allerlei dingen in acht te nemen. Het is een vrij lange lijst van voedingsmiddelen die ze niet mag eten: mais, vet, suikerriet, sampioto-groente (Min. sajoer lilin, Saccharum edule 
Hassk.), en dit alles omdat het kind in de moederschoot anders te dik zou worden, en niet meer ter wereld zou kunnen komen. Honing van andjihon, een soort bijen, die hun nest in holle boomen en spleten maken, mag ze niet eten, want daardoor zou het kind niet te voorschijn komen. Honing van gewone bijen, oeani, mag ze wel eten, want de nesten van deze diertjes worden aan den buitenkant van boomen aangebracht. Het vleesch van bahano, een groote soort kikvorschen, mag ze niet eten, omdat het kind dan net zulke groote oogen zal hebben als dit dier heeft. Ze mag geen sontjong (Poso: awati), een witte worm, die in het vergane merg van sago- en arenboomen leeft, en waaruit een kever ontstaat, eten; het zich in de diepte van den stam verbergen van deze worm is de reden, waarom de zwangere hem niet mag eten, want op dezelfde wijze zal het kind zich in de moederschoot verbergen. Om dezelfde reden mag ze geen boontjes (katimbang) eten, omdat deze zich in de peulen verschuilen. Wanneer haar ure nabij is, moet ze maar veel hongohoet-groente eten, want deze is slijmerig en daardoor zal het kind gemakkelijk naar buiten glijden.

Ze mag geen knolvruchten roosteren bij vuur waarop een kookpot staat, want dan zal het kind bij het geboren worden veel kindspek ontlasten. Wanneer een goed mensch achter de zwangere heengaat, kan zulks geen kwaad, maar een boos mensch wel, want het kind zal den aard hebben van dengeen, die achter den rug van zijn moeder voorbijgaat; daarom vermijdt men zoo iets in elk geval. Over een liggend persoon heenstappen is in alle gevallen onbehoorlijk; deed men zoo bij iemand van beteekenis, dan werd men beboet. De zwangere noch een bezoeker van haar woning mogen op de trap of op de dorpel gaan zitten; dit zou een voorspoedige ontbinding tegenhouden. Telkens als ze gegeten heeft, moet ze opstaan en haar sarong los maken om het kind in haar schoot niet vast daarin te laten beklijven. Haar draagsarong mag ze niet om den hals laten afhangen, want dit zal ten gevolge hebben, dat het kind met de navelstreng om den hals geboren wordt, waardoor het licht kan stikken. Om dezelfde reden moet ze tijdens de zwangerschap geen halsketting dragen. Zoolang ze in positie is, mag ze niet op den rug slapen, want dan zou Toempoe, de Hemelheer, het kind in tweeën deelen, zoodat ze een tweeling ter wereld zal brengen. Om dit te voorkomen mag ze ook geen aan elkaar gegroeide pisangvruchten of een ei met twee dooiers eten, of pruimen van een pinangnoot met twee kernen.

Als wat van haar gevraagd wordt, moet ze het geven; ze mag 
niets yerbergen, want zoo iets zou een yoorspoedige bevalling tegenhouden. Ook haar man mag niemand iets weigeren, want dit zou ten gevolge hebben, dat de placenta (toempoenjo of toboeni) niet uit zichzelf te voorschijn wil komen. Ze moet zorgen geen brandhout met het benedeneind in het vuur te leggen, want hierdoor zou de uitdrijving van het kind vertraagd worden. Haar man mag geen dier slachten, want anders zal het kind last hebben yan stuipen.

Bij de bevalling zit de vrouw op een lang stuk hout, waarop ze met de beide armen kan steunen om zich op to heffen bij de uitdrijving; soms houdt ze zich daartoe aan een rotanlijn vast, die aan het dak is gebonden. Haar man, haar moeder of een ander familielid zit achter haar, en steunt haar zooveel mogelijk. Vroedvrouwen kent men niet, maar bij de bevalling zijn altijd enkele ervaren vrouwen aanwezig, die helpen het foetus naar beneden te drukken; dit heet timpoeng.

Een lange en zware bevalling wordt toegeschreven aan de omstandigheid dat de vrouw haar vader of moeder in een of ander heeft tegengestaan, al is ze zichzelf daarvan misschien niet bewust. Dan verschaft haar echtgenoot een nieuwen kain, legt daarop sirih en pinang, en plaatst dit alles op het hoofd van haar ouders, waarbij vergeving wordt gevraagd voor het bedreven kwaad. Een dergelijk offer biedt men de zielen der afgestorvenen, de tominoeat, op een koperen bord (doelang) aan, als men vermoedt, dat dezen het kind tegenhouden. De booze macht, die het kind in zijne bewegingen belemmert, wordt van de barende afgedaan door haar op den buik te blazen, haar een hoofdhaar uit te trekken, en dit door de reten van den vloer te laten vallen. Men doet water in een kom, waarvan de vrouw een deel moet drinken, waarna men het overschot door de vloerlatten wegwerpt. Men licht de trap van de woning op, men maakt de mand (pandak), waarin het gezin zijn katoen bewaart, open; het haar van de barende wordt al heel spoedig losgemaakt. Meestal wordt er ook een priester bij geroepen, die aan den boehake-geest vraagt, wat de reden is van de zware bevalling.

Men gelooft ook in de pontianak, een wezen dat onder de barende tracht te komen; wanneer hem dit lukt, moet de vrouw sterven. Daarom tracht men hem weg te jagen. Wat de pontianak eigenlijk is, weet men niet te zeggen, alleen beweert men, dat hij in verband staat met een vrouw die tijdens de bevalling sterft. Sommigen zeggen: de pontianak ontstaat uit de placenta. Maar als men dan vraagt: uit welke placenta? weet men het niet. Anderen beweren, dat een dood- 
geboren kind pontianak wordt. Hij heeft de gedaante van een vogel, maar schreeuwt als een kikvorsch.

Er zijn er die zeggen, dat de pontianak bij voorkeur zijn verblijf houdt op het graf van een in het kraambed gestorven vrouw, dat hij onder voortdurend krijschen tracht te openen. Anderen weer zeggen: dat de pontianak dicht bij het dorp woont; liefst op verlaten akkers. In elk geval zijn de vrouwen van het dorp zeer bang, als een harer in het kraambed sterft; ze binden zich dan medicijn op den buik om zich tegen de anvallen van den pontianak te vrijwaren.

In het Baloasche waar men de meening is toegedaan, dat de pontianak uit een doodgeboren kind ontstaat, worden de groote teenen van de beide voeten van het doode wicht aan elkaar gebonden om te voorkomen, dat het wezen, dat er uit ontstaat, op zal vliegen. Overigens wordt in beide clans het lijk van een doodgeboren kind in een regenmatie gewikkeld, en op de gewone begraafplaats in den grond gestopt.

Ook bij het lijk van een in het kraambed gestorven vrouw neemt men bepaalde maatregelen in het Baloasche: haar beide beenen worden aan elkaar gebonden. Verder wordt haar lijk bij beide clans behandeld als dat van iemand, die aan een natuurlijken dood is heengegaan, en alle ceremoniën voor de dooden worden voor haar in acht genomen. Van eenige plechtigheid om alle andere vrouwen voor eenzelfde lot te behoeden, weten de Loinangs niet.

Van de wijze waarop een kind ter wereld komt, trekt men zich niets aan. Of het in voetligging geboren wordt, of het op den vloer neerkomende het gelaat naar beneden of naar boven gekeerd heeft, dit is den menschen precies hetzelfde. Wanneer een jongen op den maandag toempa geboren wordt, zal hij extra dapper zijn. Van kinderen, die met den helm geboren worden (hampe kila-kilamboen) gelooft men, dat ze lang zullen leven, en dat ze onkwetsbaar zijn.

Wanneer kind en placenta beide geboren zijn, wordt iemand geroepen, die gewend is de navelstreng door te snijden. In het Lingketeng-gebied wordt de streng op twee plaatsen met zwart garen afgebonden, en tusschen die twee bindsels wordt zij doorgesneden. In het Baloasche gebeurt het afbinden op 3 plaatsen, en wel met wit garen; de streng wordt zóó doorgesneden, dat er twee bindsels zijn aan het stuk, dat aan het kind vastzit. Dit stuk moet zóó lang zijn, dat het uiteinde totaan de schaamdeelen reikt. Op de streng en daaronder wordt een stukje curcuma (kini) gelegd, en dan wordt ze doorgesneden met een scherpen bamboesplintęr (emban), door hẹt bovenște 
stukje curcuma heen tot op het onder de streng liggende brokje.

De placenta (toempoenjo ,de eigenaar van het kind”, of toboeni) wordt met water begoten; dan perst men er kokosmelk over uit. Vervolgens wikkelt men haar in het Baloasche in een lap wit katoen, en begraaft haar een vier meter van het huis af; in welke richting dit gebeurt komt er niet op aan. In 't Lingketengsche legt men de placenta in een kokosdop (oensoen), plaatst er de andere helft bovenop, en bindt dan beide halfbollen stevig aan elkaar; daarna wordt ze aan den Oostkant van de woning begraven. Liefst laat men dit werk door een oude van dagen doen, opdat het kind zoo oud moge worden als deze. De oude slaat zich daartoe eerst een doek over het hoofd, opdat zijne oogen niet naar rechts of links zullen dwalen. Onder het graven van het gat, moet hij (zij) het lichaam doodstil houden, anders zal het kind veel huilen. Wanneer de placenta in het gat ligt, wordt er asch op gestrooid en als het gat weer dichtgemaakt is, plant de oude vier bamboetjes op die plek. Weer in huis teruggekeerd (ook op den terugweg blijft hij (zij) strak voor zich kijken) wordt er een matje gespreid, en daarop legt hij (zij) zich te slapen. Na enkele oogenblikken bootst een der huisgenooten het gekraai van een haan na, en dan staat de oude op. Men zegt zoo te doen, opdat het kind altijd rustig zal doorslapen.

Als de oude is opgestaan, neemt hij (zij) eenige aangescherpte bamboelatten (hamba), voor een jongen zes, voor een meisje acht, en plant deze schuin in den grond aan den kant van de woning, waar de bevalling heeft plaats gehad, opdat de booze geesten, die moeder of kind kwaad willen komen doen, in die bamboes zullen loopen, en gewond terugijlen (in het Baloasche laat men het aantal van deze bamboelatten niet afhangen van het geslacht van het kind, maar plant men 3, 4, 8 of 9 randjau's, al naar gelang men van plan is over $3,4,8$ of 9 dagen het feestje voor den kleine te geven). Verder neemt hij (zij) kokos- of sagobladeren, en omheint daarmede de plek onder het huis, waar het bloed van de kraamvrouw is neergekomen; die omheining heet boombong ,versperring” (het planten er van is momoombong). Wanneer het kind enkele dagen na de geboorte sterft, graaft men de placenta weer op, en begraaft deze samen met het lijkje op het kerkhof. Nimmer wordt de nageboorte in een boom opgehangen.

Zoodra het kind ter wereld is gekomen, wascht men het met lauw water (dit wordt volgehouden, zoolang het kind klein is). Dan legt een der aanwezigen een ui op het voorhoofd van het wicht en zegt: 
Komioe tenak, anoe nontenak mae maaloem aia na ponsalamat mami, da boli mae okinde na anak „Gij schutsgeesten (dit moeten kleine djins zijn), die den moederschoot bewaakt tot ons heil, laat niemand komen, die met het kind zijn spel drijft". Ook legt men op een bord een stuk katoen en daarop sirih-pinang. Dit zet men bij het hoofd van het kind voor de zielen (tominoeat) van de afgestorvenen, wier hulp men mede inroept om het kind te beschermen tegen aanvallen van den ,,setan”.

Men beweert nog goed te weten, dat vroeger in het gebied der Loinangs geen wiegen (todjongan) werden gebruikt, maar nu ziet men ze in het Lingketengsche hier en daar, in navolging van de bewoners van het strand. In 't Baloasche is de wieg nog onbekend.

Wanneer de vader niet bij de bevalling van zijne vrouw tegenwoordig is geweest, legt zijn schoonmoeder hem bij zijn komst in huis een ui tegen het voorhoofd, en daarna doet de vader hetzelfde bij zijn kind. Dit wordt gedaan om te voorkomen, dat kwade invloeden, die misschien samen met den vader konden zijn meegekomen, het zwakke wicht zouden benadeelen. Van het geven van een geschenk door den vader van het kind aan zijne schoonouders is geen sprake: Een eerstgeborene heet toempe, de middelste is pantonga, en de jongste is tampaloei; jongens en meisjes vormen echter afzonderlijke reeksen, zoodat men spreekt van toempe moane, de eerstgeboren jongen, en toempe booene, het eerstgeboren meisje.

Bij de Baloa-clan tracht de vader ook te weten te komen of zijn kind een lang leven is beschoren. Daartoe zal hij den eersten nacht na de geboorte wakende doorbrengen om het geroep der vogels te beluisteren. Wanneer de keketi, de vogel die in het Pososche popoko heet, zich in den voornacht laat hooren, zal het kind spoedig sterven; hoort hij den vogel middernacht, dan zal het kind groot worden, maar als jongmensch sterven. Roept de vogel pas tegen den morgen, dan zal de pasgeborene den middelbaren leeftijd bereiken. Maar als de vogel zich heelemaal niet laat hooren, is dit een bewijs, dat het kind pas op hoogen leeftijd zal sterven. In het laatste geval herhaalt de vader de proef gewoonlijk in den tweeden nacht om volkomen zekerheid te erlangen. Dit voorteeken noemt men ambolo mampatoe.

De kraamvrouw wordt met lauw water gewasschen. Ze wordt op een hellend vloertje gelegd, dat tawas heet, en naast haar wordt vuur aangelegd, waaraan ze zich warmen kan. Of het vloertje wordt naast den algemeenen haard geplaatst, zoodat de kraamvrouw van het vuur dat daarop brandt, kan genieten. Elken dag wordt haar buik gewreven 
om alle inwendige organen weer in hun normale houding te brengen. Zoodra de kamponggenooten hebben vernomen, dat de kleine geboren is, komen ze de kraamvrouw bezoeken. Als geschenk heeft men wat rijst en een stuk gerookt gemsbuffelvleesch bij zich, welke geschenken den naam dragen van polaboti. Ook brengt ieder een stuk hout met vuur mee, dat op het haardje bij de kraamvrouw wordt neergelegd. Men zegt er uitdrukkelijk bij, dat dit dient om te voorkomen, dat de setan de moeder kwaad zullen doen. Bij dit met zich dragen van vuur zal men dus wel de gedachte hebben om de booze invloeden, die met de bezoeksters mee kunnen komen en kraamvrouw en kind kwaad kunnen doen, af te weren of te verjagen. Over enkele dagen, als het feestje voor den pasgeborene zal worden gevierd, zal de vader zorgen, dat elk dezer vuurbrengsters een kippepoot als toespijs bij den maaltijd krijgt.

Wanneer de vrouw een jongen ter wereld heeft gebracht, mag zij gedurende zes dagen geen sago, of iets waaraan kokos is toegevoegd, eten. Men meent dat de buik van de kraamvrouw nog niet sterk genoeg is om deze dingen te verdragen. Ze mag ook geen koud water of palmwijn drinken. Haar eenige voedsel bestaat eigenlijk uit een dikke soep van gemsbuffel vleesch met rijst; men zegt, dat hierdoor zog wordt opgewekt. Ze mag ook niet zelf koken.

Zes dagen na de geboorte van een jongen, acht na de geboorte van een meisje heeft bij de Lingketeng-clan een feestje voor de pasgeborene plaats; bij de Baloa-menschen gebeurt dit 3, 4, 8 of 9 dagen na de geboorte, al naardat men dit vooraf heeft bepaald. Dit feestje heet malapa' boombong ,,de versperring verwijderen", n.l. het hekje dat om de plek is gemaakt, waar het bloed van de kraamvrouw is gevallen. De kamponggenooten dragen voor dit feestje hoenders en rijst bij, opdat de vader over een voldoend aantal kippepooten kan beschikken om die aan de gasten voor te zetten. Bij deze gelegenheid worden de randjau's en de heining om de bloedplek uitgetrokken, bijeengebonden en aan een paal van de woning opgehangen. Dan gaat de moeder met haar kind in de armen naar beneden; op den grond gekomen gaat ze op een daar neergelegd hakmes staan, en dan komt een oude van dagen met vier Dracaena bladeren in de hand, en raakt daarmede hoofd, schouders, knieën en enkels van den kleine aan, onder het uitspreken van een zegenwensch. Daarna gaan de oude en de moeder samen die Dracaena planten. Bij sommige families legt men op die plek ook de bladeren van het heininkje onder het huis neer, inplaats van ze aan een huispaal te binden. 
Vaak gaat de moeder op dezen dag ook baden, maar zonder haar kind. Op weg naar het water strooit ze voortdurend asch om zich heen, terwijl ze een aangestoken lont, abitang, van katoen met zich draagt, om de booze geesten op een afstand te houden. Het kind wordt pas veel later naar het water gebracht, wanneer het al kan loopen. Hierbij neemt men geenerlei voorzorgen. Eerst wanneer het een jaar of acht geworden is, durft men het meenemen naar het zeestrand. Wanneer dan op dien eersten verren tocht voor het kind de moeder aan een groote rivier komt, neemt ze daaruit twee steenen, en slaat die vóór het gelaat van het kind driemaal tegen elkaar; waarbij ze zegt: „Zoolang deze steenen niet vergruisd zijn, zal je geen kwaad treffen".

Gedurende de eerste drie dagen na de bevalling wordt het kind door een ander gezoogd, waarna de moeder hiermee doorgaat. Heeft ze geen zog, dan weet men geen ander middel om dit op te wekken dan het eten van de bovengenoemde krachtige soep. Kan de moeder haar kind niet helpen, of is ze overleden, dan wordt de kleine door een andere vrouw gezoogd. Is deze een tante of een ander nabestaand familielid, dan is er geen sprake van belooning; maar moet dit werk aan een ander worden opgedragen, dan wordt loon gegeven; iemand noemde mij als loon een blok ongebleekt katoen (balasoe) voor elke drie maanden. Zoogbroer en zoogzuster mogen niet met elkaar huwen.

Wanneer een kind veel huilt, heet dit kajangoen. Dit komt omdat booze geesten het plagen. Om dezen af te weren neemt men kruiden en verpakt die in zwart katoen, waarna het pakje om den hals van het kind wordt gebonden. Of men legt op een vierkant stuk pisangblad wat rijst en de bloemkolf van een pisang, en dit brengt men naar den rand van het bosch, waar men het neerzet met de woorden: „Dit is ons offer, kom het kind niet meer plagen”. - Of men heeft een fout begaan tegenover de doodenzielen (tominoeat), of de bochake-geesten. Dan wordt hun een offer aangeboden, op een koperen schaal (doelang) gelegd, en men vraagt hun om vergeving. Of men bedenkt dat een der grootouders het kind nog niet heeft gezien, en het wel eens kon huilen uit verlangen naar die persoon. Dan wordt ze gehaald en men verwacht, dat het kind daarna bevredigd en rustig zal zijn.

$\mathrm{H}$ et $\mathrm{K}$ ind. Men gelooft dat het kind met zijne geboorte alle teekenen meebrengt, waaruit kan worden opgemaakt, welke geaardheid het later zal vertoonen, en welke trekken zijn leven later zullen 
kenmerken. Daarom bekijkt de moeder het lijfje van haar kleine nauwkeurig om te zien waar zich zwarte plekjes (ela, Pososch ila) vertoonen, want alle hebben hun beteekenis. Heeft het kind er een op den rug, dan wacht hem veel verdriet, want al zijne kinderen, die het later op den rug zal dragen, zullen sterven. Veel verdriet zal ook zijn deel zijn als het zoo'n vlekje onder een der oogen heeft; daar is de weg der tranen en het zal veel weenen om verliezen in de familie. Heeft het kind zoo'n vlekje bij den neus of het oor, dan zal het later veel voordeel en geluk in zijn leven hebben. In de handpalmen zegt het vlekje. dat het 't geluk zal vasthouden, en dat alles wat het zal doen, zal gelukken. Vertoont zich op den benedenarm een ela, dan zal het kind later veel dooden begraven, die het in den arm neemt om het lijk in de kist te leggen. Heeft het kind een ela in de linkerliesstreek, dan zal het veel rechtszaken in zijn leven hebben; heeft het zoo iets aan de rechterlies, dan zal het in alle twistzaken winnen. Twee kruinen (poesising) op het hoofd voorspelt, dat de ouders van het kind spoedig zullen sterven. Heeft het drie haarwervels op het hoofd, dan zal het later veel huisdieren bezitten. Deze vlekjes op de huid hebben voor jongens en meisjes dezelfde beteekenis.

Als het kind loopen kan; dus een jaar of twee oud is, wordt er weer een feestje gegeven, dat mompoladjang ,laten loopen” heet. De dorpsgenooten brengen dan weer eten bij elkaar en ze verzamelen zich in het feesthuis. Bij aanzienlijke gezinnen neemt het Hoofd het kind in den arm, en gaat er mee naar beneden; met het gelaat naar het Oosten gewend spreekt hij een zegen over het wicht uit, dezelfde dien we straks zullen aantreffen bij het korten der tanden. Daarna zet hij den kleine overeind op den grond, en daar ontvangt hef allerlei geschenken van vrienden en bloedverwanten, die er om heen staan: kleeren en sieraden. Tegenwoordig geeft men den kleine geldstukken, die op den grond gelegd worden, vanwaar het kind ze opraapt. Bij gewone lieden doet een oud man denzelfden dienst voor het kind, en wordt er voor den maaltijd slechts een enkel hoen geslacht. Bij de aanzienlijken wordt onder het verrichten van deze plechtigheid voortdurend op de trom en de gong geslagen, en den heelen nacht door wordt er gedanst en feest gevierd.

Niet lang daarna wordt ook het hoofdhaar van het kind voor 't eerst gesneden, mongkiis. Aanzienlijken slachten daarbij een hoen, waarvan het kind een poot te eten krijgt; armen doen het af met een ei. Iedereen kan worden uitgenoodigd het haar van het kind te snijden. Dit wordt daarna op een tak van een kokos- of een sagoboom gelegd. 
De naam van het kind is al vastgesteld voordat het geboren is; die naam wordt meestal door een der grootouders bepaald. Wanneer de navelstreng wordt doorgesneden, wordt de gekozen naam daarbij uitgesproken, want degeen die dit doet zegt : „Ik snijd de navelstreng van N.N. (den naam van het kind) door". Is de kleine vaak ziek, dan schrijft men dit wel daaraan toe, dat het zijn naam niet goed vindt. Dit wordt door een priester verklaard, die geroepen is om eens aan den boehake-geest de reden te vragen waarom de kleine altijd sukkelend is. Die priester geeft dan tegelijkertijd een anderen naam op, dien het kind wel zal bevallen.

De ouders laten zich bij den naam van het kind noemen met voorgevoegd ,,vader van” (toema $i$ ), en ,moeder van” (tina $i$ ), bijv. Toema. i Goeliis, Tina i Goeliis. Grootouders worden aangeduid met Ikai i Goeliis ,grootvader van Goeliis”, en Kele i Goeliis ,grootmoeder van Goeliis". Ook ooms en tantes maken van dien naam gebruik, en heeten dan: Babo i Goeliis „oom van G.”, en Ka'aka of Dada i Goeliis ,tante van G.”. Kent men den naam van een kind niet, dan spreekt men een jongen aan, of roept hem met tatoe ,ventje”, een meisje met oedoe.

Een gehuwd paar voedt vaak het kind van verwanten op. Het wordt echter niet officieel geadopteerd. Wanneer het aangenomen kind niet in een verhouding tot de kinderen zijner pleegouders staat, waardoor een huwelijk met een hunner als bloedschande wordt beschouwd, is een echtverbintenis tusschen die twee niet verboden. Maar zoo iets schijnt toch zelden voor te komen, omdat de jongelui er zich voor schamen, want de dorpsgenooten beschouwen hen als broer en zuster.

Besnijdenis van jongens is geheel onbekend. Men had van zoo iets (behalve van de Mohammedaansche soenat) nimmer gehoord; wanneer ik vertelde, hoe dit onder de Posoërs wordt gedaan, veroorzaakte dit steeds groote hilariteit onder de hoorders. Alleen een oude man in Baloa vertelde, dat het boven in het bosch wel eens gebeurde, maar hij wist er geen bizonderheden van mee te deelen.

Wanneer de melktanden uitvallen, worden deze op den haard begraven, opdat een hoen ze niet zal oppikken. De oorlellen worden bij meisjes van een jaar of zes doorgestoken; men doet dit door middel van een ring, die uit de steenvrucht (konta) van de aren gesneden wordt ; deze ring die op één punt doorgesneden is, wordt met de beide uiteinden aan weerszijden van den oorlel geklemd; het sap uit de vrucht bijt de huid en het vleesch uit. In het daarD1. 86. 
door ontstane gat steke men een staafje van doloepang-hout (Poso: doloepo, een hooge woudboom). Is de wond genezen, dan verwisselt men genoemd staafje met een van sagobladsteel. Dit wordt herhaaldelijk door een dikker staafje vervangen, totdat het gat wijd genoeg geworden is om er een oorknop (djaling) van inlandsch maaksel in te dragen. Ook doet men er wel een opgerold boomblad, bloemen of strengetjes kralen in. Rijke meisjes dragen oorknoppen en oorhangers van goud en zilver, die van handelaars worden gekocht.

Het maken van brandwonden op den bovenarm door middel van arenzwam, zooals alle Toradja-stammen dit doen, kennen de Loinangs niet. Aan tatoueeren heeft men nooit gedaan. In den lateren tijd is men zijn naam en allerlei figuren op den onderarm gaan tatoueeren, maar deze kunst heeft men van de soldaten geleerd, die op geregelde tijden in deze streek komen patrouilleeren.

T andenkorten. Wanneer de tander der kinderen worden gekort (monggisin), wordt een groot feest aangericht, dat dikwijls heel kostbaar is, en daarom wacht men er gewoonlijk mee tot er een aantal kinderen zijn, van wie de tanden dan bij dezelfde gelegenheid gekort kunnen worden. Daarom is de leeftijd waarop dit plaats heeft, zeer verschillend; in elk geval zorgt men, dat het gebeurd is tegen den tijd, dat de puberteit intreedt. Er moeten heel wat etenswaren bijeengebracht zijn, voordat men tot het korten van de tanden kan overgaan. De voormalige tonggol van Pinapoean heeft mij opgesomd wat hij bijeen had gebracht, toen hij dit feest voor de laatste maal had gegeven: 30 bamboekokers (winoentoeng) met gerookt varkensvleesch (als zoo'n bamboekoker voor vleesch voorzien is van een deksel van hetzelfde materiaal, dan heet hij tatale), twee levende gemsbuffels, een menigte hoenders en manden vol gepelde rijst, en tusschen 40 en 50 bamboekokers met palmwijn. Het bijeenhalen van het benoodigde brandhout, bladeren om de spijzen in te pakken, en bamboes, geeft ook veel arbeid. Aan de woning wordt een verlengstuk aangebouwd voor al de gasten die aan het feest deelnemen. Op den vooravond van het feest wordt het eten klaar gemaakt; dit heet momboeka." Rijke lieden verzamelen de dorpsgenooten wel eens gedurende acht avonden voordat het feest begint in hun huis, waarbij zij ze te eten geven. Deze gasten houden gedurende den nacht reidansen (montontila), waarbij gezongen wordt. In dit gezang vragen ze den feestgever om allerlei geschenken.

Op den eersten morgen van het feest om een uur of 7 , worden de kinderen, die de operatie zullen ondergaan, jongens en meisjes, 
naar het water gebracht, waar ze zich baden en de tanden goed reinigen. In huis teruggekeerd vindt elk kind een matje voor zich gespreid op een rij naast elkaar. De rij moet gevormd zijn naar den leeftijd der kinderen, beginnende bij den oudste tot den jongste toe. Jongens en meisjes liggen door elkaar naar gelang van het nummer, dat ze in de rij naar hun leeftijd innemen. Ieder kind gaat op het voor hem bestemde matje zitten.

Dan nadert het Hoofd of een ander persoon van aanzien; deze legt de rechterhand op het hoofd van het eerste kind in de rij, en zegt: Koepomalemo i Anoe, po'oehanna toempo'o hoboeng; po'oehanna boeling; po'ochanna masala; po'oehanna ma'andjoe; po'oehanna manaboe poso; po'oehanna tabas oe mian; po'ochanna maboehoek, po'oehanna ponga. Nokaoemoelakon, nokakekeakon, nokahosanakon, nokasipatakon, nokawadjipakon. Isa, doea, toloe, opat. „Ik doe N.N. (naam van het kind) nederliggen, dat hij niet op jeugdigen leeftijd sterve; dat hij geen dief worde; dat hij niet verkeerd moge doen (d.i. overspel plege); dat hij niet door den stroom worde meegesleurd; dat hij niet (uit een boom) dood valle; dat hij niet door een ander gedood worde; dat hij niet vreesachtig zij; dat hij niet dom zij. Dat hij een hoogen leeftijd bereike, dat het hem tot ijver (aansporing) worde, dat het hem tot kracht worde, dat hij vlug worde, dat hij er waardig van worde (om eenig ambt te bekleeden). 1, 2, 3, 4". Bij die ,vier” duwt de zegenaar het hoofd van het kind naar beneden, zoodat het op het matje wordt uitgestrekt. Zóó doet hij achtereenvolgens met al de kinderen, wier tanden gekort zullen worden.

De operateurs zijn altijd mannen; er zijn er even veel als er kinderen te behandelen zijn, want iedere operateur neemt één kind onderhanden. Zijne vrouw helpt hem daarbij. Deze zit bij het hoofd van het kind en houdt met een reepje katoen de bovenlip opgetrokken; dit heet mompa-oloen. De man slijpt de rij tanden met een steen af; deze dompelt hij herhaaldelijk in een kom met water, waarin een stuk van het binnenste van den pisangstam is gelegd. Gewoonlijk worden de tanden tot op de helft afgeslepen; maar er zijn er ook, bij wie de operateur maar heel weinig van de tanden heeft overgelaten. Bij hen die tot het Christendom zijn overgegaan, gebeurt dit niet meer. Is de bovenkaak klaar, dan worden de tanden van de onderkaak afgeslepen. Wanneer men ook hiermee gereed is, moet de operateur ten slotte nog viermaal langs den rand van de tanden van de bovenkaak schuren, voordat hij den steen mag neerleggen. 
Onder het slijpen heeft het kind alle geestkracht noodig om elke kermende zucht (toloengoes) te onderdrukken. Want als hem gekerm ontsnapt, terwijl de bovenkaak geslepen wordt, zou vader of moeder spoedig komen te sterven; overkwam het hem, terwijl men bezig is met de onderkaak, dan zou de patient zelf of zijn operateur spoedig komen te sterven. Is zoo iets gebeurd, dan moet spoedig een priester komen om het kwaad, dat zich aan de betrokkenen heeft gehecht, en op hen inwerkt, van hen af te halen (piloeloes). Als tijdens de operatie een boom omvalt, moet een van de kinderen spoedig sterven.

Tijdens het slijpen der tanden houden de gasten op den grond spiegelgevechten, waarbij zich trom en gong voortdurend laten hooren.

Volgens het zeggen der menschen duurt het ongeveer twee uur om de tanden van een persoon te korten. Terwijl men bezig is met slijpen, verzamelen de familieleden zich in het huis, en zoodra het werk is afgeloopen, brengen zij aan de nog liggende patienten een kleedingstuk: een sarong, een broek, een baadje of een hoofddoek. Als dit is afgeloopen, worden de kinderen weer één voor één door het Hoofd opgericht met het uitspreken van een zegen, zooals deze boven is meegedeeld. Hij wrijft dan met een stuk sirihvrucht over de afgeslepen tanden. $\mathrm{Na}$ hem komt de vader van het kind, en smeert het wat zwartsel op de lippen. Dit zwartsel heet doli, en het wordt verkregen door hout van kaoe gocin te verbranden, en de rook er van tegen een hakmes aan te doen slaan, waar het roet zich op vastzet. De patiënten laat men dan aan hun lot over: ze mogen doen wat ze willen. Niet lang daarna heeft een groote maaltijd plaats, en wordt de nacht met allerlei spelen en dansen doorgebracht.

Dadelijk na afloop van hun werk gaan de operateurs met hunne vrouwen naar huis, en dan wordt elk hunner achterna gedragen : een bamboekoker met vleesch, een hoeveelheid gekookte rijst, een stuk zout, een pluk tabak voor den man, en de helft van deze hoeveelheid voor zijn vrouw, die hem geholpen heeft. In den namiddag komen ze terug om verder aan het feest deel te nemen.

Den volgenden morgen is het feest afgeloopen, en dan wordt onder de gasten katoen rondgedeeld; bv. 5 blokken balasoe worden in stukken gescheurd voor hen die aan de reidansen hebben deelgenomen, en 5 andere blokken mogen degenen die zittende allerlei spelletjes hebben gedaan, onder elkaar verdeelen. Dit heet ponggodos of sadaka (Mal. sedekah, Boeg sidakka, enz., uit 't Arabisch).

Vier dagen na de operatie, wanneer de pijn uit de tanden ver- 
dwenen is, heeft er nog een klein huiselijk feest plaats, dat posompo lanjoe heet. Bij deze gelegenheid worden de tandstompjes ingewreven met het reeds genoemde zwartsel (doli).

$\mathrm{S}$ p e le n. Spelen is mohaik of biang. Alles wat de kinderen groote menschen zien doen, trachten zij in hun spel na te volgen. Zij koken zand in stukjes kokosdop, ze leggen tuintjes aan en bouwen huizen. Maar ze hebben ook spelen zooals wij die onder dit woord verstaan. Zoo kennen zij de tol, gasing, die denzelfden vorm heeft als bij de Posoërs. Men speelt er ook op dezelfde wijze mede als de Toradja's doen. Op mijn vraag of er een tijd voor tollen is vastgesteld, antwoordde men mij steeds: Neen, de kinderen mogen het doen wanneer ze willen. Mijn verblijf onder de Loinangs viel tusschen den rijstoogst en het openen der nieuwe akkers, maar ik heb nergens zien tollen. De exemplaren, die ik op mijn verzoek te zien kreeg, moesten uit de huizen worden gehaald.

Een veel geliefd spel is dat met babele; dit is een stukje kokosdop, dat in den vorm van een bijltje is gesneden. Gewoonlijk speelt men dit met z'n zessen. Drie leggen hun babele naast elkaar op den grond; de drie anderen hebben hun stukje kokosdop met den bollen kant op den grond gelegd, op een afstand van ongeveer 4 meter er vandaan; bij het smalle gedeelte van hun babele steken ze een stok in den grond, en slaan er tegen met een ander hout, zoodat de kokosdop over den grond tolt, en een der drie andere stukjes raakt. Dit is ten minste de bedoeling. Missen alle drie het doel, dan moeten ze hun babele voor de anderen neerleggen.

De papadjoet is een stok, op welks uiteinde men een klont leem plakt, die daarna naar een bepaald doel wordt weggeslingerd. Men schommelt op een rotan, welks beide einden aan een boomtak zijn vastgemaakt; ngkang kadoem be'an noemt men dit. Graag schieten jongens met een proppenschieter, die van een dunnen bamboe is gemaakt op dezelfde wijze als in Poso (Toradja's II, 388). Men maakt spuitjes van bamboe, waarmee men water naar elkaar toe spuit, pana noe oee geheeten. Ladjangan ,waarop men loopt”, zijn stelten, stokken waaraan een stukje hout gebonden is, waarop de voet wordt gezet. Kinderen loopen ook graag op een paar kokosdoppen, ladjangan moensoen, die ze met een koord, dat tusschen de teenen doorgaat, tegen de voetzool klemmen. Verstoppertje spelen, manintampoeng of toemampoeng, doet men veel. Kuitschoppen, mobinde, is ook onder de Loinangs een geliefd spel.

Onder de reidansen neemt het montontila een eerste plaats in. Voor 
het Christelijk deel van het volk moet ik hier in den verleden tijd spreken, want de inheemsche predikers trekken sterk tegen deze dansen te velde, en verbieden ze. Ik heb ze dan ook niet gezien in het Christelijk deel, en in het Heidensche waren de omstandigheden er niet gunstig voor. Dr. Kaudern heeft het zien doen (I Celebes obygder II, 330). Men doet het zoowel in huis als op den grond, en in onderscheiding van den algemeenen reidans, het moraego bij de Oost- en de West-Toradja's, waaraan geen gehuwde vrouwen mogen deelnemen, doen dezen aan het montontila wel mee. Kaudern vertelt dat de deelnemers achter elkaar aan gaan, waarbij zij hunne handen leggen op de schouders van den voorman. Mannen en vrouwen vormen elk een afzonderlijke rij. Zoo draait men langzaam in een kring tegen de zon in rond, onder het aanheffen van een eentonig gezang. Nu en dan schreeuwen de mannen op, en stampen daarbij op den vloer (of op den grond). Deze reidans wordt den heelen nacht volgehouden. De strophen die worden gezongen, heeten soelat tontila.

Een ander soort zang is montende; deze heet zoo omdat elke strophe met het woord tende begint. Men zingt zittende. Hieraan nemen alleen jongens en mannen deel, en terwijl de mannen bezig zijn, loopen de vrouwen af en aan met bamboekokertjes en nappen palmwijn, waaruit ze de mannen laten drinken (mompo'inoe), en met allerlei eetwaren, die ze den mannen in den mond stoppen (monsosoki).

Iets dat op dezelfde wijze wordt uitgevoerd als het montende is het docadoengkala, dat Kaudern ook heeft zien doen (I Celebes obygder II, 330). Hij zegt, dat dit gedaan wordt om een gast te eeren. Volgens de verklaringen der menschen zou men eerder kunnen zeggen, dat de gasten er hun gastheer mee eeren, die zij prijzen om zijn gulheid en dergelijke. Kaudern vertelt dan, dat de gasten en hun gastheer in een kring tegenover elkaar zitten. Beiden nemen hun nap met palmwijn op, en de gastheer zingt samen met de anderen, die tegenwoordig zijn, een welkomstlied voor den gast. Onderwijl zwaaien allen hun bekers in 't rond voor, achter, boven en onder elkaar; en als de zang ten einde is, drinkt elk den nap van zijn buurman leeg.

Een reidans die mondampas heet, moet volgens de beschrijving veel overeenkomst hebben met het mokajori der Posoërs, waarbij twee partijen elkaar toezingen en in verbloemde taal hun wenschen en bedoelingen en voornemens te kennen geven. Een man gaat voorop, die de strophen maakt, welke door de anderen worden nagezongen. 
Deze voorzanger heet ocloebalang; de achterste in de rij dansers is de polopi.

Over het houden van spiegelgevechten (oemapos) heb ik al iets gezegd. Ik moet er alleen bijvoegen, dat men dit ook doet bij gewone feesten, vooral bij het feest voor het korten der tanden. Terwijl de mannen hun spiegelgevechten houden, maken de vrouwen ook allerlei passen, waarbij ze met een doek in beide handen op en neer bewegen onder het voortdurend uitgillen van lele! lele! Hiernaar heet deze vrouwendans monsalele. Mijn Maleisch sprekende zegsman noemde dezen dans ,het tjakalele der vrouwen”. Aangezien ik het niet heb zien doen, kan ik het niet nader aangeven. Op den weg en in huis zingt men liedjes; dit heet mongelok. Men vertelt allerlei dierenverhalen en sprookjes, oendoe-oendoeon, en verhalen, die waar gebeurd heeten te zijn, overleveringen (sisikon).

$\mathrm{M} \mathrm{uz}$ i e k. Naast dansen en zingen heeft men ook allerlei instrumenten, waarmee men muziek maakt. Daar is de taoedo of tatendo, een bamboe, die aan twee zijden in de lengte is uitgesneden, zoodat hij 2 tongen vormt, die door het handvat, dit is het ondereinde van den bamboe dat in zijn geheel gelaten is, bij elkaar gehouden worden. Deze stemvork van bamboe wordt in trilling gebracht door de lippen op de muis van de linkerhand te slaan. Kaudern heeft van het voorkomen van dit muziekinstrument een overzicht gegeven in het derde deel van zijn Results of the authors Expedition to Celebes: „Musical Instruments in Celebes", waarin ook een en ander te vinden is over de andere hier te noemen muziekinstrumenten der Loinangs. Men vertelde mij, dat jongens en meisjes elkaar des avonds met dit instrument serenades gaan brengen, en dat zij in de wijze waarop ze het bespelen kunnen uitdrukken, welke gevoelens ze tegenover elkaar koesteren. Toen ik mijn zegslieden vroeg mij dit eens voor te doen, antwoordden ze lachende, dat ze de kunst verleerd hadden, en dat ze er te oud voor waren geworden. Tijden waarop wèl, en waarop niet op dit instrument mag worden gespeeld, kent men niet.

De mondharp, ohing, ziet er precies zoo uit als de Pososche woring (Toradja's II, 385). Men zingt er op: gong, gong, homa koelinding ,gong, gong, wiens naam spreek ik uit”, en dan tracht het meisje den naam van den jongen door de tong van haar instrument te laten zeggen, en de jongen zoo met den naam van het meisje.

De poponting is een geleding zware bamboe, waaraan aan beide zijden het schot is gelaten; hierin is een gaatje geboord. Van de bast van den bamboe is een reep opgelicht, die door middel van aan beide 
einden ondergeschoven stukjes hout vrij komt te staan; als men de snaar aanslaat begint ze te trillen en geeft geluid; onder de snaar is een gat in den bamboe'gesneden. Men vertelde mij, dat dit instrument niet inheemsch is, maar van lieden van het strand is afgekeken. Zoo zag ik ook aardig afgewerkte harpen met 7 snaren, die van boombast waren gedraaid. Deze harp heet gamboeoes; ze is een navolging van de ketjapi, die men aan het strand had leeren kennen. Men sprak ook van een primitieve viool, die alabaa wordt genoemd, welk woord een verhaspeling zal zijn van rebab. Er is ook nog een kortere die talindo heet, en waarvan de snaren met de vingers worden getokkeld. Geen van de beide instrumenten heb ik te zien kunnen krijgen, omdat ze niet vooradig waren op de plaatsen waar ik er naar gevraagd heb.

Van fluiten kent men de toclali, een bamboe met vier gaten voor de toonhoogten; ze wordt rechtuit voor den mond gehouden. Aan het eind van den bamboe waarvan de fluit gemaakt is, is het schot gelaten, en daarin is bovenaan in schuine richting een gaatje gebrand; dit gat wordt gedeeltelijk toegedekt met een reepje pandanblad, en daartusschen blaast men de lucht.

De kokoeak is een kleine klarinet van een rijsthalm, aan welks uiteinde een schelp wordt gewonden van sagoblad.

Wanneer men kennis wil geven, dat men op reis wil gaan, of dat men van een tocht is teruggekeerd, blaast men op een Nautilus-schelp; bocoet noemt men zoo'n ding. Men makt het na van een stuk zware bamboe, waarvan aan het eene eind het schot is gelaten; men blaast in een gat, dat dicht bij dit schot in den wand van den bamboe is gebrand. Dit namaaksel noemt men ook boeoet.

Onder de slaginstrumenten vinden wij de koedendeng of golondong, een bamboegeleding, waarvan aan beide zijden de schotten zijn gelaten. In de lengte is een reep van den bamboe weggesneden; de Loinangsche tongtong. Men geeft er seinen mee door er op verschillende wijzen op te slaan.

Het voornaamste slaginstrument in de trom (gandang). Ze is van een uitgehold stuk hout (een stuk van een boomstam) gemaakt, en ongeveer tweemaal zoo lang als de middellijn van de doorsnede bedraagt. Beide einden zijn met herte- of slangevel overtrokken. Men bespeelt de trom zittende, waarbij zij op de dijen wordt gelegd; aan de eene zijde slaat men er met een stok, aan de andere met de hand op. De trom wordt niet gebruikt als de priester zijn werk doet. Vooral wanneer men gemeenschap zoekt met den geest van den 
stamvader, den pilogot, moet het juist heel stil zijn. De trom wordt alleen geslagen bij feestelijkheden: om het rythme van den dans aan te geven en het gezang te begeleiden. Wanneer men met succes van de jacht teruggekeerd is, slaat men uit vreugde een roffel op de trom. Een rol bij den godsdienst schijnt dit instrument nimmer gespeeld te hebben. De onafscheidelijke metgezel van de trom is de gong.

\section{Dood en Begrafenis.}

De Loinang kent ook verhalen, waarin wordt verteld, dat de menschen vroeger niet stierven, maar oud geworden van huid wisselden en dan weer jong waren. Eens ging een vrouw naar het water om van huid te wisselen. Toen zij hiermee bezig was, kwam daar een man, die Liko-likooenon heette. Deze schrikte van het vreemde gezicht, en riep uit: „Wat doe je daar!” Van dezen uitroep schrikte op haar beurt de vrouw, en hierdoor ging het proces van de huidwisseling niet door; sedert gebeurt het niet meer, en moeten de menschen sterven.

Ik heb al medegedeeld, hoe de man den eersten nacht na de geboorte van zijn kind wakende doorbrengt om uit het geschreeuw van den keketi-vogel op te maken of zijn kind een lang leven beschoren is, of niet.

Soms gebeurt het ook, dat een boehake-geest door middel van een priester mededeelt, dat de stamvader (pilogot) heeft verteld, dat dit of dat kind door verdrinken of door een omvallenden boom zal worden gedood. De ouders worden dan gewaarschuwd om hun kind ver van water, en uit de buurt van zwaar geboomte te houden.

In den loop van mijne mededeelingen hebben wij al meermalen kunnen zien, hoe geluiden of handelingen van dieren aan de menschen voorspellen, dat er dooden zullen vallen. Ik voeg hier nog enkele van die gevallen bij: Wanneer een loeloen djaling-slang of een oelo wont $i$ (een soort slang) op het woonerf verschijnt, moet de eigenaar van dat huis sterven, tenzij een priester den toover van den bedreigde afhaalt door het reeds beschreven miloeloes. Hetzelfde moet ook dadelijk worden gedaan, wanneer een omineuze vogel zich onder een huis laat hooren, of dit schreeuwende doorvliegt. Of wanneer zoo'n vogel een kreet slaakt, terwijl men bezig is aan het bouwen van een huis. Als een balk die men bij het bouwen op wil brengen, valt, moet een van de huisgenooten spoedig sterven. Of men brandt kalk en deze wordt zwart; dan zal een van de kalkbranders spoedig sterven. 
Wanneer een muis aan het hoofdkussen knaagt of aan het eelt van den voet bijt, weet men dat men moet sterven. - Als een padde op het woonerf schreeuwt, moet men dadelijk haar naam kongkong! roepen, want als men dit niet doet, zal men uitteren en sterven. Een andere soort padde heet bahangkakak; als deze bij een huis komt schreeuwen, spreekt men haar toe: „Maak daar geen leven, wie van mijn bloedverwanten zal sterven, ik weet het al”. Als het dier dan ophoudt met schreeuwen, komt het zeggen, dat een familielid den geest zal geven. Gaat het door met kwaken, dan heeft dit geen beteekenis.

Als een vuurvlieg (kochap) 's avonds binnenvliegt, en in het haardvuur verbrandt, meende men in den ouden tijd stellig, dat een der aanwezigen zou worden gesneld. Gaat de vuurvlieg op het droogrek $(o m b a)$ boven den haard zitten, dan zegt dit alleen, dat men op de jacht een hert of een varken zal krijgen. - Aan vlinders (tentelengan) hecht men geenerlei geloof; alleen als een nachtvlinder (toka-toka) 's avonds op het vuur afkomt, houdt men zich verzekerd, dat er den volgenden dag een gast zal komen; is de vlinder wit, dan zal hij in het wit gekleed zijn, is ze geel, dan is de gast iemand in gele kleeren.

Een python heet bintana. Deze dieren schijnen aan de Loboe niet voor te komen, althans zoo beweert men; wel aan de Toimaa. Komt zoo'n dier in een dorp, dan is dit een teeken, dat een groot onheil dreigt, dat velen zullen sterven. Men moet de slang dan met rotanstrikken zien te vangen, en vastbinden. Dan begiet men haar kop met water, waarbij men spreekt: „Dit water reinige de slang, opdat het oordeel des doods haar zelf treffe en niet ons". Daarna doodt men haar. Heeft men geen water bij de hand, dan doodt men haar ook zonder dit, maar met dezelfde woorden. Als men ergens heen op weg zijnde een slang over het pad ziet kruipen, moet men zich neerzetten, pruimen en een sigaret opsteken. Ongeveer een uur lang moet men rust houden, en in dien tijd mag men niets zeggen of doen.

Wanneer de ijsvogel (djengket), die alleen overdag zijn geluid laat hooren, een enkele maal in het donker een kreet slaakt, zal er een doode in het dorp zijn.

Behalve deze voorteekenen in verband met dieren geven droomen aan, of men spoedig zal sterven. Ziet men een zieke in den droom als eèn ellendig wezen, met vuile kleeren aan, dan zal hij herstellen. Ziet men hem als een welgedaan en goed uitgerust persoon, dan wil dit zeggen, dat hij spoedig zal heengaan. Als ik droom, dat ik een tand verlies, zal een kind van mij sterven, of mijne vrouw (een man 
wist nog te vertellen, dat het uitvallen van een tand uit de bovenkaak een zoon, uit de benedenkaak een dochter beteekent). - Wanneer ik droom dat $\mathrm{ik}$ den heer te Kintom een hand geef, dan wil dit zeggen dat ik spoedig zal sterven. Als een waterstroom die door zwaren regen ontstaat, voorbij een huis trekt, zal daar iemand sterven. Droom $\mathrm{ik}$ dat ik een rivier oversteek, maar den overkant niet kan bereiken, dan heb ik niet lang meer te leven; haalt men den overkant wel, dan moet iemand anders uit dat huis of dat dorp sterven. Als in den droom mijn speer breekt, zal ik een zoon door den dood moeten verliezen; breekt mijn kapmes, dan sterft mijn dochter. Zien we in den droom iemand in een prauw wegvaren, dan zal die persoon sterven. Wanneer men een berg beklimt, en den top niet bereikt, zal men niet lang meer te leven hebben. Wanneer in den droom mijn hoofdhaar wordt gesneden, zal ik spoedig heengaan; zie ik mijzelf met lang hoofdhaar, dan beteekent dit een lang leven. Ook de man, die droomt dat hij rotan voortsleept, mag op een lang leven rekenen.

Volledigheidshalve noem ik hier nog enkele andere droomen: Valt men in zijn droom uit een boom, dan rekent men er op om de eene of andere reden beboet te zullen worden. Vooral als men in den droom door den stroom wordt meegesleurd, wacht die persoon een zware boete. Droomt iemand, dat hij geluisd wordt, dan zal hij ziek worden. Zie ik iemand in den droom zijn gevoeg doen, dan spreekt men kwaad van $\mathrm{mij}$.

Wanneer werkelijk gebeurt wat men gedroomd heeft, als men bijvoorbeeld een varken doodsteekt, na dit den nacht te voren in den droom gedaan te hebben, of iemand inderdaad tot mij komt, die mij al in den droom heeft bezocht, dan heet dit mompaton. De gewone wijze om te maken dat een kwade droom niet in vervulling gaat, is, dat men 's morgens naar de rivier gaat, en in het water zittende den droom vertelt, er aan toevoegende, dat hij niet in vervulling gaat; daarna duikt men viermaal in het water onder en gaat vervolgens naar huis. Gaat het om het leven, dan wordt er een priester bij geroepen, die op water in een kom blaast; van dit water drinkt die persoon een deel, en met de rest wascht hij het gelaat. Voor het wegdoen van de werking van een droom wordt niet het miloeloes gebruikt.

Wanneer iemand op sterven ligt, spreekt men hem aldus toe: Hengetoem atina boai boetongoem, olaa pinosangalocjoem pooenaakon mae $i$ anakoem, $k a$ boli oko minsaloengi bahangkakak, olaa minsaloeng $i$ koëkot, ka kami mamba $i$ kochat, otimbang kaidckan, opoto'i akon 
noe ambolo anoe maidek; ka otimbang ka'imaan mami, da opoto'i akon noc ambolo anoe ma'ima. „Uw ziekte heeft uw lichaam meegenomen, wil slechts uwe genegenheid laten blijven (onderhouden) voor uwe kinderen; ga niet in een padde (manifesteer $u$ niet in een padde, die den menschen den dood komt aanzeggen), maar belichaam $u$ in de uil, en als wij naar het bosch gaan, en gij ziet iets slechts (dat ons bedreigt), geef ons daarvan dan kennis in een leelijk voorteeken; en als ge iets goeds ziet (dat we voordeel en geluk zullen hebben), wil ons dit dan te kennen geven in een goed voorteeken."

Wanneer een stervende zijn broer of zuster ankijkt, en dan de oogen op zijn kind richt, waarbij hij de vuist dichtknijpt, dan wil hij daarmee zeggen: „Zorg goed voor mijn kind”. — Men let er bij een stervende op, of de laatste adem merkbaar uit den mond komt. Is dit het geval, dan is men overtuigd, dat de levensgeest (santoeoe) naar Toempoe ,den Eigenaar (van alles)” is teruggekeerd. Blijft de mond gesloten, dan zegt men, dat de levensgeest uit een andere opening van het lichaam, bijvoorbeeld uit de aars, weggaat. Dan wordt de levensgeest een boos wezen, setan.

Eerst als de stervende den laatsten adem heeft uitgeblazen, mag men hoor- en zichbaar weenen en klagen. Dan wordt ook op de gong geslagen, telkens met lange tusschenpoozen één slag. Dit heet montoebangi.

Een lijk heet in het bovenland bangke. Meer naar zee toe zegt men biok. In het bovenland is dit biok een krachtwoord geworden, dat men gebruikt als men pijn heeft of verbaasd is. Dat de beteekenis er van niet vergeten is, blijkt uit het verbod om dit woord te zeggen als men oogst, rijst draagt, kortom in nauwe aanraking met dit gewas is; dan zal de rijst verdwijnen en men zal honger lijden.

Wanneer een lijk de oogen openhoudt niettegenstaande men ze gesloten heeft, moet iemand uit de omgeving spoedig sterven, want dan kijkt de doode rond wien hij mee zal nemen. Blijft alleen het linkeroog geopend, dan zal een verre bloedverwant sterven; is alleen het rechteroog niet gesloten, dan moet een van zijne kinderen sterven. $\mathrm{Om}$ dit te voorkomen houdt iemand de hand boven de oogen van den stervende, en dekt ze toe, als de laatste adem is uitgeblazen. Sterft iemand onder een zwaren doodstrijd, zoodat hij onrustig is en met de handen aan de kleeren plukt, dan is hij in zijn leven een roover geweest. Laat hij de tong uit den mond hangen, dan was hij een leugenaar. Komt er bloed uit den mond van het lijk, dan is de doode door een heks vermoord. 
De behandeling van het lijk is bij beide clans nagenoeg dezelfde. Zoodra de dood is ingetreden, legt men het lijk met het hoofd naar 't Oosten, de beenen naar 't Westen. Dan maakt men het voedsel voor den doode klaar: 7 stukjes gemsbuffel- of varkensvleesch, want kippevleesch of visch mag men den doode niet geven; heeft men geen gerookt vleesch in huis, dan vraagt men wat aan een ander. Verder een bord (lean, een groot soort bord heet lean bola) met gekookte rijst en een kommetje (patongko) met palmwijn. Dit alles plaatst men boven aan het hoofd van den doode, samen met sirihpinang. Dan worden hem de kleeren uitgedaan; dit doen bloedverwanten, mannen behandelen het lijk van een man, vrouwen dat van een vrouw; de kleeren worden straks ook naar het graf gebracht. Eén persoon giet met de linkerhand telkens wat water op het lijk, en een ander wrijft het met de linkerhand af; soms wordt daarbij schrapsel van hanggi-hout (Poso: langgiri, Albizzia saponaria) als zeep gebruikt. De harsfakkel (soeloe), die bij het lijk brandt, wordt met de linkerhand uitgekrabd om haar helderder te doen branden. Dan wordt het lijk weer aangekleed in nieuwe kleeren; alleen voorname personen krijgen een dubbel stel kleeren over elkaar aan. Verder wordt wat zwartsel (doli) met de linkerhand over de lippen gestreken : driemaal over de beneden- en viermaal over de bovenlip. In het Lingketengsche wordt ook het haar met kokosschrapsel gewasschen en uitgekamd.

Is de doode aangekleed, dan worden twee banen wit katoen op den vloer uitgespreid, een el langer dan het lijk is; de stukken liggen met den lengterand over elkaar. Hierop wordt de doode gelegd, en dan slaat men het katoen over het lijk toe. Bij het hoofd en bij de voeten wordt het katoen in mekaar gefrommeld samengebonden; een derde band gaat om het middel. Ten slotte pakt men het nog in een mat van pandanbladeren. Op deze wijze bindt men het aan een stok (pombilian), of legt het op een draagbaar (hansa-hansa of hensa-hensa), en op die manier draagt men het 't huis uit langs de trap met de voeten vooruit.

Gewoonlijk wordt het lijk begraven op denzelfden dag, waarop die persoon gestorven is. Alleen wanneer b.v. een kind sterft, waarvan de vader op jacht is, gaat men dien dadelijk halen, en dan duurt het wel eens 2 of 3 dagen, voordat het lijk wordt weggebracht. Terwijl men de wacht houdt bij het lijk, kort men zich den tijd met het doen van allerlei spelletjes, en het voordragen van vertellingen. Wanneer een verteller even naar buiten moet, neemt hij vuur 
met zich mee, anders zou hij op de plaats doodblijven, aangevallen als hij wordt door allerlei booze geesten.

Wanneer iemand in het huis van een ander sterft, moet de familie van den doode 1 of 2 stukken ongebleekt katoen (balasoe) aan den huisheer geven. Heeft men echter iemand uit een ander dorp om de eene of andere reden tot zich geroepen, en sterft de geroepene in de plaats waarheen hij zich heeft begeven, dan wordt degene die den ander geroepen heeft, met 4 stukken van dat katoen beboet.

Van lieden, die bijzonder ijverig zijn geweest, zoodat ze altijd voldoende rijst hadden, van menschen, die boven de anderen uitstaken in rijkdom en dapperheid, neemt men wel eens wat van de haren van baard en hoofd, en van de nagels. Men bewaart deze relieken, opdat de genoemde hoedanigheden van deze dooden op de levenden zullen overgaan. Van lieden die zich in niets van hunne medemenschen onderscheiden hebben, houdt men niets van dezen aard achter.

De meeste lijken worden in een kist begraven; alleen personen die niet veel verwanten hebben, die een kist kunnen maken, worden wel gewoonweg in hun mat begraven. Als men een lijkkist, solongan, ${ }^{1}$ ) gaat maken, komt het er niet op aan hoe de boom, dien men voor dit doel omhakt, valt. Alleen wanneer men onder het maken van de kist een van de vogels toentochoeis, koclisdo of mongee hoort, houdt men zich overtuigd, dat er binnen korten tijd weer een doode zal zijn; hiertegen is niets te doen.

De kist die het meest gebruikt wordt, en die katoele heet, bestaat uit drie lange planken en twee kleine om de einden af te sluiten. De bodem van de kist is een gewone plank, langs welks randen gleuven zijn ingesneden, waarin de beide andere planken rusten. Deze twee planken zijn eenigszins uitgehold, zoodat ze de gedaante hebben van vlakke goten. Als het lijk op de onderste plank is gelegd, worden de twee zijplanken in de gleuven van de eerste gezet en over het lijk heengelegd, zoodat de beide andere randen elkaar boven den doode, dien ze overwelven, raken. De doorsnede van de kist heeft dan deze gedaante:

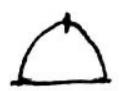

Men heeft zulke kisten van losse planken ook met 4 lange en 2 zijstukken; maar deze soort komt

1) Vgl. het Pososche sosoronga, een kistje waarin de beenderen van een lijk werden ongeborgen, die bij het doodenfeest waren schoongemaakt. Sosoronga en solongan betekenen „de plaats waar (het gebeente, het lijk) ingaat". 
minder voor ( deze heeten solongan). Eertijds had men deze kisten in voorraad; in de nog heidensche dorpen van Mantan zag ik onder bijna elk huis nog een of meer solongan staan. Ik zag daar ook één kist, zooals de Posoërs die maken: een boomstam, die als een prauw is uitgehold, met een daarbij passende deksel. Zulk een kist wordt eenvoudig kaoe ,hout" genoemd; men vertelde mij, dat ze alleen voor Hoofden en voorname lieden worden genfaakt, en dit klopt met de mededeeling van een ouden man van Baloa, dat in zijn clan slechts nu en dan zulk een kist voor een doode wordt gemaakt, terwijl ze veel meer voorkwamen bij de Lingketeng-clan, die uitgebreide Hoofdengeslachten heeft. Ik spreek hier weer in den verleden tijd, want in de streken waar men tot het Christendom is overgegaan, worden geen solongan of kaoe meer gemaakt, maar spijkert men een lijkkist van zes gewone planken in mekaar. De kisten van Kamboa, Idjam en Obaki, waarvan ik boven een en ander heb verteld in verband met de vereering, die eerstgenoemde geniet, zijn alle als prauwen met een deksel er op. De steenen waarop de kisten staan, heeten de polanggan; de kist met de beenderen heet soeli-nsoeli; iemand wiens lijk op deze wijze op een stelling is geplaatst, wordt mian sinanda ,iemand die gesteund wordt" genoemd. De daka'njo (kapitan) van Lingketeng vertelde mij, dat wanneer eertijds een Hoofd op sterven lag, hij aan de omstanders mededeelde van welken boom hij zijn doodkist gemaakt wilde hebben. Het geven van een dergelijke opdracht door een stervende heet molawit.

Bij het graven van het graf, mongkele bolo, worden geen bizondere dingen in acht genomen: alleen moeten de gravers zorgen om steeds het aangezicht naar het Westen gewend te houden. Wanneer het graf gereed is, moet er altijd iemand de wacht bij blijven houden, want anders zouden booze geesten komen, en het gat weer met aarde dichtwerpen. Wordt het lijk in een kist begraven, dan wordt deze leeg in het graf gezet, waarna het lijk daarin wordt neergelaten.

Ik heb reeds gezegd hoe het lijk wordt uitgedragen. De weduwe en de kinderen, die de hoofden met een lap wit katoen hebben overdekt, loopen in den stoet mee. Ze dragen met zich een mand waarin 7 borden; is de overledene een vrouw, dan is de mand een basoeng, is hij een man dan een kawako. In het eerste geval gaan ook haar kapmes mede; in het tweede zijn speer en zijn zwaard.

Is men bij het graf aangekomen, dan wordt het lijk op den rand er van neergelegd. Mat en lijkwade worden een weinig geopend, zoodat het gelaat zichtbaar is, en dan spreekt een der aanwezigen 
den doode toe: „Ga nu rustig uws weegs; neem niet mee uwe dapperheid, uw ijver en uw rijkdom, uw vernuft en uw kracht, laat dit alles voor uwe kinderen; loop langzaam voort, opdat ge $\mathrm{u}$ aan niets stootet; kijk niet om en denk niet meer aan uwe verwanten en uwe kinderen, want gij zijt nu aangekomen bij uw (overleden) vader, moeder en verwanten, wij blijven nog wat achter; geef ons nog lang te leven". Dan wordt het lijk in het graf gelegd, op de plank, als het een kist krijgt, waarna de banden, waarmede de lijkwade is gebonden, losgemaakt en op het lijk gelegd worden. In het Baloasche maakt men dan nog eens het gezicht vrij en zegt: Komioe mala'ikat anoe monaolaja mae na mala'ikat boeooe. „Gij overledenen van vroeger (die vroeger gestorven zijt) roept de pas overledene”. Men legt daarna op den buik van den doode een bord gekookte rijst, op het hoofd een kommetje, en op de voeten een klein bordje; een gewoonte die men in het Lingketengsche niet kent. Men zegt zoo te doen, opdat de doode, wanneer hij zich opricht, dadelijk zal zien, dat alle eetgerei aanwezig is.

$\mathrm{Nu}$ worden de planken over het lijk heengestulpt, of wanneer de doode in een kist ligt het deksel er op geplaatst; niets wordt vastgebonden; heeft de doode geen kist, dan wordt ook niets over het lijk gelegd, en komt de aarde rechtstreeks op het matje neer, waarin het gewikkeld is. Terwijl het graf nog open is, hakt iemand een rotan door, wat mompatak sipit heet, en daarbij zegt hij: „Dit is voor het laatst dat gij ons ziet, kijk niet om naar uw verwanten, maar blijf hier". De twee stukken rotan worden in het graf geworpen. Hierop wordt het graf zonder meer dichtgegooid, en men bouwt er een voorloopig hutje van sagobladeren op. Het dak van deze hut moet met 7 stuks atap bedekt zijn, die omgekeerd (met den rug naar beneden) worden aangebracht. Begraven heet mompatoooen.

Wanneer men van het graf teruggaat, is het de weduwe die dit 't laatst verlaat. Ze zegt tot de ziel van den overledene: „Dit is de weg!” Want men onderstelt, dat de ziel straks naar het sterfhuis teruggaat, zooals we zullen zien. Thuisgekomen wasschen allen zich de handen, en zeggen: „Alleen ditmaal wasschen we de handen, we willen het niet nog eens doen" (m.a.w. er zal niemand meer sterven, dien we moeten gaan begraven). Men zegt er ook wel eens bij: Andjoehakon $i$ Togi'an. „Drijf af naar Togian, n.l. de ziekte of datgene wat de persoon ten grave heeft gesleept, die men pas is gaan begraven.

Tegen den avond van den dag der begrafenis zet men op den weg, die naar het graf leidt een kokosdop met water; rechts er van steekt 
men 4 kippeveeren in den grond, en links 3. Men doet dit, zegt men, opdat de ziel van den overledene, wanneer zij straks naar huis komt, daarop zal trappen; want hierdoor pas zal men overtuigd worden, dat hij overleden is.

Nadat degenen die aan de begrafenis deelgenomen hebben, gegeten hebben (men maakt van dezen maaltijd echter geen bijzonder werk) blijven allen bij elkaar in het sterfhuis. Men is doodstil, geen licht mag worden ontstoken, en op deze wijze wacht men de komst van de ziel van den overledene af. Midden in den nacht hoort men een geluid, alsof iemand een stok in den grond steekt, of de deur piept, of de vloer kraakt; als het regent hoort men voetstappen in het nat: dat is de ziel die haar voormalige woning komt bezoeken. Men hoort aan het brandhout op den haard morrelen, en een zacht trillend geluid: rrrr! de ziel rilt van koude en ze wil het vuur aanmaken, dat gedoofd is, omdat er geen licht mag zijn. Soms ziet men iets lichtends, maar dit heeft geen vorm. Dan is het of een koude tocht strijkt over het gelaat van de weduwe, van hare kinderen of van andere verwanten van den overledene: dit is de doode die zijn geliefden betast. Als een hunner in slaap is gevallen, begint hij of zij vaak in den slaap te praten: de slapende spreekt met den doode, en schudt hem wakker, anders kon de overledene hem wel eens meenemen.

Wanneer deze teekenen van de aanwezigheid der ziel goed zijn waargenomen, begint men op eens te roepen: ,hij is er! hij is er!” Dan ontsteekt men spoedig de fakkel en blaast het vuur aan; want de overledene wordt gevolgd door booze geesten, die de draagbaar (hensa-hensa), waarop het lijk is weggebracht, en die bij het graf is gelaten, aandragen om daarop levenden weg te brengen. Of ze besprenkelen de verzamelden met lijkevocht (sagoe), zoodat ze sterven moeten. Allen heffen dan een hevig geween aan (toomando). Men eet wat, en brengt het overige van den nacht wakende door. De volgende avonden mogen vuur en licht niet uitgaan; afwisselend slaapt en waakt men. De wakenden vertellen elkaar oude verhalen (oendoe-oendoeon), of geven elkaar raadsels op. Dit is de eenige tijd, waarin men dit mag doen. Van deze verhalen en raadsels (tangkitangkion) heb ik eenige opgeteekend, die ik aan dit opstel toevoeg.

Nadat de weduwe van het graf is teruggekeerd, moet ze de rouwgebruiken in acht nemen; dit heet mondosoakon. Voor elken doode is er één persoon die mondosoakon. Sterft een weduwe of weduwnaar dan zal een zoon of dochter, een broer of een zuster de rouwplichten op zich nemen; voor een kind doet de moeder het gewoonlijk. Ik D1. 86. 
zal voor het vervolg onderstellen, dat het de weduwe is die de rouwplichten vervult.

Met matten wordt er een hokje (dat ook salipi heet) in huis afgeschoten, waarin ze zich terugtrekt. Ze moet zoo weinig mogelijk spreken, en als ze het doet, fluistert ze. Wanneer ze naar beneden gaat, moet ze het hoofd altijd met den witten doek bedekken. Buiten de twee bijzondere gelegenheden, waarvan beneden sprake zal zijn, mag ze eigenlijk niet baden, maar als er plassen zijn met stilstaand water, die in den drogen tijd verdwijnen, mag ze zich daarin wasschen. Ze mag niet zelf koken. Rijst is niet voor haar verboden, maar bij voorkeur eet ze pisang en oebi. Dat is ook het voedsel, dat aan den doode op zijn graf wordt gebracht. Wel krijgt deze óók rijst, maar dit wordt op een andere plaats gebracht, zooals we straks zullen zien. De spijzen, die voor haar verboden zijn, zijn sago en mais. Wanneer ze een sirihpruim wil nemen, moet ze eerst wat sirih-pinang voor den overledene op een bord naast zich neerleggen; zoo ook zondert ze van alles wat ze eet op dezelfde wijze een weinig af. Telkens komt de ziel van den overledene haar in den slaap betasten; dan schrikt ze wakker en heft een geween aan (toemando). Wanneer ze zich in dezen tijd niet in acht nam, zou, ,het lijk (biok of bangke) haar beschuldigen”, en ten gevolge daarvan zou ze onnoozel of krankzinnig worden. Op de gedenkdagen voor den doode eet ze niet met de gasten mee.

Wat er verder met de weduwe gebeurt, zullen we straks zien. We moeten eerst nagaan hoe men verder den doode verzorgt. Zoodra men van het graf is teruggekeerd, hebben ook de familieleden allerlei in acht te nemen: men mag niet schreeuwen, niet op gong of trom slaan; in 't kort: alle rumoer moet worden vermeden. Wanneer een familielid tegen dit voorschrift zondigt, zal zijn mond verstijven of zijn hals zal worden verdraaid. Men geeft hem dan een stukje menschenscalp te eten, of strijkt hem daarmee over de lippen, dan zal hij beter worden.

Op den derden dag na de begrafenis, die boelanjo ito-itoloe heet, makt men op de plek waar de nap met water is neergezet, die den doode moet overtuigen, dat hij gestorven is, een klein huisje, laigan ise' of sohonsang geheeten. In Lingketeng maakt men de 4 staken, waarop het dakje rust van hout, in Baloa van bamboe. Er is een vloertje van bamboelatjes in: het is niet grooter dan $3 \times 3$ decimeter. Het dakje mag uit niet meer dan 3 stukjes atap bestaan, die omgekeerd (met den rug naar beneden) worden aangebracht. Een trapje 
bestaande uit een stok met inkervingen wordt omgekeerd (met de treden naar beneden gewend) tegen het vloertje aan gezet. In dit hutje plaatst men drie borden, waarop gekookte rijst en verschillende vleeschsoorten; verder legt men er in: drie pisangs en wat suikerriet. Er wordt ondersteld, dat na de oprichting van dit hutje de ziel van den overledene niet verder komt dan tot dat punt. Op den dag van de oprichting heeft in het sterfhuis een maaltijd plaats, waaraan echter alleen familieleden van den overledene deelnemen.

Op den zevenden dag na de begrafenis (boelanjo ipi-ipitoeng) heeft weer zoo'n intieme maaltijd plaats. Heel in de vroegte gaat de weduwe naar het meergenoemde hutje en baadt zich daar. Als de overledene nog kleine kinderen heeft, worden die daar ook gebaad. Men spreekt daarbij: „Alleen deze keer baad ik hier; nu zijn er geen dooden meer". De kinderen moeten door het water bespat worden, waarna men uitroept: sinongkomo, ,(ik ben) overal getroffen (door het water)". Want anders baadt een booze geest hen, en dan worden ze heelemaal zwart. De maaltijd die hierop volgt, heet pelaboti. Iedere gast krijgt daarbij 3 bakjes met toespijs, hetzij met hetzelfde, hetzij met verschillende gerechten. Alle bladeren die bij deze gelegenheid noodig zijn, moeten na gebruik op den grond worden geworpen. Een deel van het voedsel wordt naar het hutje gebracht. Naar het graf gaat men niet in deze dagen, daarvoor is men bang.

Op den veertienden dag $(2 \times 7$ dagen $)$ na de begrafenis heeft dan het eigenlijke doodenfeest plaats, dat moliwang heet. De weduwe is in den vroegen morgen, als het nog donker is, naar het hutje geweest om er te baden, met of zonder kinderen, want zij moet weer in huis zijn, als de mannen komen mongkahoehoei (Lingketeng) of manggoha'i (Baloa). Uit alle dorpen in den omtrek zijn menschen uitgenoodigd om te komen mongkahoehoei. Voor dag en dauw zijn ze er soms al, geheel uitgerust in oorlogscostuum met de soealang op, met speer en schild. Ze moeten er vóór het aanbreken van den dag zijn, want dan is de ziel van den overledene er nog, en het is juist hun bedoeling deze te verjagen, opdat ze niet meer in het sterfhuis terugkeere. Met heel veel geschreeuw en telkens den krijgskreet aanheffende (dit laatste is mekahoehoei, en hiernaar is in het Lingketerigsche de plechtigheid genoemd) bestormen ze als het ware het sterfhuis, waarbij ze geweldig op den vloer stampen. Alle eigendommen van den overledene, die ze vinden kunnen, eigenen ze zich toe. Men rekent hier natuurlijk op, en daarom zetten de nabestaanden 
een deel van die bezittingen, die ze voor dit doel willen afstaan, klaar; de rest bergen ze in de salipi of in de rijstschuur op.

Hebben de mannen (het zijn er doorgaans zeven, in Lingketeng staan ze onder leiding van een priester) alles geroofd, dan leggen ze dit bij elkaar, en begeven zich naar het hutje halfweg het graf; dit hakken ze stuk en eigenen zich de daarin liggende borden toe. In 't Lingketengsche gaan de mannen door naar het graf, waarvan de grafhut onaangetast gelaten wordt, maar alles wat op het graf voor den doode gezet is, wordt meegenomen. Gewoonlijk steekt de leider van den troep nog een klaargemaakte jonge arentak (taliti), zooals men die maakte als men van een sneltocht terugkwam, in het dak van de hut. Als men bij deze gelegenheid een groote vlieg (leleoeang) om het graf ziet vliegen, of het is alsof er een schaduw over 't graf glijdt, dan meent men, dat er spoedig weer iemand moet sterven. In het Baloasche gaan de mannen niet door naar het graf, omdat men hier geen voorwerpen voor den doode er bovenop zet. Zijn de mannen weer in het sterfhuis teruggekeerd, dan verdeelt het Hoofd de buit onder hen.

Intusschen is er een groote maaltijd klaar gemaakt, want alle inwoners van het dorp, en nog velen uit den omtrek zijn opgekomen om aan de plechtigheid deel te nemen. Deze bestaat hierin, dat de mannen naar het bosch gaan, en uit duurzaam hout een dak voor het graf hakken. Dit dak heeft den vorm van een halven cylinder; het wordt door allen naar het dorp gesleept, en daar op vier, maar meestal twee palen opgericht. Zoo'n houten dakhut heet laloeng (fig. 134 in Kaudern's I Celebes obygder II geeft een duidelijke voorstelling van zoo'n grafhut). Wanneer daarna de groote maaltijd is afgeloopen, wordt de nacht verder doorgebracht met allerlei spelen, want men heeft geheel met den doode afgerekend. Met dit moliwang is ook de tijd voor het opgeven en oplossen van raadsels afgeloopen.

Twee dagen later gaat de weduwe in den vroegen morgen met een dracaenatak (tabang) in de hand naar het water, baadt zich, en steekt de tak aan den kant van het water in den grond. Een van de bladeren draait ze om tot een peperhuis, en steekt dit met een stukje hout vast. In dit peperhuisje legt ze wat sirih-pinang, en spreekt aldus : „Nu zijn we gescheiden (mogamba of mogaa); gij zijt naar alehat (Ar. acherat) gegaan, en daar kunt ge doen zooals ge wilt; ik ben hier op aarde gebleven, en ik zal ook mijn gang gaan". Die dracaenatak heet bojontoegon of pogaatan ,scheidingsteeken”. Dan gaat ze naar huis terug, en ze mag haar gewone leven hervatten. De lap wit 
katoen blijft ze als rouwteeken dragen tot ze weer hertrouwt; fatsoenshalve wacht ze hiermee eenige maanden, opdat men haar niet zal verwijten, dat ze niet van den overledene heeft gehouden, of opdat men er haar niet van verdenken zal, dat ze haar man door zwarte kunst uit den weg heeft geruimd.

In huis teruggekomen wordt er nog een intieme maaltijd ge.houden, waarbij een priester tegenwoordig is, die een hoen slacht en toebereidt, waarvan hij een deel op een koperen schaal (doelang) legt, samen met gekookte rijst. Dit is voor den overledene bestemd, die daarbij toegesproken wordt. Deze plechtigheid heet monsale, waaruit blijkt, dat de bedoeling er van is om gemeenschap te oefenen met den overledene. Men zegt dan ook, dat men zulks doet om te maken, dat de ziel van den overledene niet te ver weg zal gaan, maar bij het gezin zal blijven om dit op den duur in alle moeielijkheden des levens als pilogot bij te staan.

Voor kinderen en arme lieden worden al die gedenkdagen tot één dag beperkt, namelijk op dien volgende op den dag der begrafenis. Er wordt dan geen hutje gebouwd en het graf wordt niet van een houten bekapping (laloeng) voorzien. Bij sommige dooden worden de feesten tot 7 dagen beperkt: de maaltijd die op den zevenden dag wordt gehouden, heeft dan op den derden plaats, die van den veertienden dag op den zevenden. In elk geval komt men de eigendommen van den overledene rooven, en de schim wegjagen; al gebeurt dit bij de kleine lieden door een enkelen man.

Bij aanzienlijken worden na het mongkahoehoei eenige boomen omgekapt, die de overledene zelf geplant heeft: van zijn pisangboomen één; zoo ook één van zijn sago- en van zijn kokos- en pinangboomen. Dit omkappen moet met de linkerhand gedaan worden.

Men zal zich wel wachten om op een van de gedenkdagen van iemand, die in zijn omgeving gestorven is, op zijn rijstveld te gaan werken, want als men dit deed zouden de muizen den aanplant verwoesten.

De begrafenis van een Hoofd en van iemand uit het volk heeft hetzelfde verloop, alleen wordt van de teraardebestelling van een Hoofd meer werk gemaakt. Zoo graaft men om de laatste rustplaats van een tonggol een goot, en hoogt de plek met aarde op. Dan is ook de rouw (het modoso), die 3 dagen duurt (totdat het hutje halfweg het graf is gemaakt) veel strenger en deze wordt niet alleen door de familieleden van den overledene, maar door alle bewoners yan het dorp en van den ointrek in acht genomen: dan mag men 
geen vuur buitenshuis aanmaken, geen versch hout kappen, niet in den grond graven, geen speer in den grond steken, geen padi stampen. Wanneer een daka'njo was gestorven, werd deze rouw zeven dagen volgehouden. Anderen zeggen, dat deze strenge rouwverboden alleen voor den derden dag na de begrafenis golden. Op de andere dagen had men alleen maar te zorgen, dat men geen leven maakte. Bij den dood van een daka'njo kwam een tonggol mongkahochoei.

Ik moet hier nog iets naders mededeelen over de doodkisten van Kamboa, Idjam en Obaki, die op steenen staan, in plaats van in den grond te zijn begraven. Toen Kamboa op zijn sterfbed lag, zei hij tot de omstanders, dat zijn lijk niet in den grond mocht worden begraven, maar dat men de doodkist met zijne beenderen op een rotspartijtje moest plaatsen, vlak in de nabijheid van de plek waar het oude dorp Lingketeng lag. Het deksel mocht ook niet op de kist worden vastgebonden, anders zou de doode het te benauwd hebben; er waren zelfs gaten in de zijwanden der kist gebrand. Een slaaf werd aangewezen om bij de kist te waken, en de vliegen weg te jagen. De vrouw van den slaaf bracht haar man zijn eten, en dit at hij, aan den kant van de kist gezeten, op. Hij koos die zijde, waar de wind op dien tijd de lijklucht van hem afwaaide. De slaaf droeg den naam van Poling (ik heb verzuimd te vragen of dit de eigennaam van den man was, dan wel de aanduiding als wachter, want ook bij de kisten van Idjam en Obaki werd zoo'n waker aangesteld). $\mathrm{Na} 2 \times 7$ dagen, dus na het doodenfeest (moliwang), werd de slaaf met heel zijn gezin vrij verklaard. Een enkele maal moest er een nieuwe kist voor de beenderen worden gemaakt; meermalen is de grafhut (laloeng) vernieuwd. Als dit moest gebeuren, werden alle verwanten van Kamboa uit 't Lingketengsche en het Kintomsche bijeen geroepen, en dan had de vernieuwing met veel feestelijkheid plaats. Dit heette mombalii loengoon (als loongoen hetzelfde is als loemoe „doodkist”, beteekent deze naam ,de doodkist verwisselen, nieuwmaken"). De kist moet van taiti- of van oehoe-hout (Michelia Celebica) gemaakt zijn, omdat dit duurzame houtsoorten zijn. Men moet zorgen, dat de afmetingen geheel dezelfde zijn als de vroegere. De beenderen werden uit de oude kist genomen door een paar mannelijke nakomelingen van Kamboa, die ze met olie inwreven, in een lap wit katoen wikkelden, en in de nieuwe kist legden. Kleeren en andere voorwerpen, die aan den doode waren meegegeven, en die sedert vergaan waren, werden vervangen. Het feest had in het dorp plaats, maar dit bestond alleen in het houden van maaltijden. 
Voedsel voor den doorluchtige overledene mocht niet naar het graf worden gebracht, want daardoor zouden de nakomelingen overlijden. Dit offer legde men in den namiddag om een uur of 4 neer op het koperen bord (doelang), waarop ook de sirihdoos staat, en waar de pilogot (geest van den stamvader) neerdaalt, als men gemeenschap met hem houdt. Kamboa is de eenige daka'njo, wiens lijk op deze wijze wordt behandeld, want Idjam en Obaki waren tonggol en mian kopian.

$\mathrm{Z}$ i e 1 e n $\mathrm{Z}$ i e 1 e n 1 a nd. Waarheen de ziel na den dood gaat is den Baloa-menschen geheel onbekend. Ze zeggen: „Bij 't graf, bij de woning, en op den duur wordt ze pilogot". In 't Lingketengsche heeft men allerlei verhalen over de ziel. Ze gaat naar alehat (acherat). Eerst komt ze aan een water, dat den naam draagt van Oeë noe kalakaoesa. Aan den kant van dit water groeit een boom, kaoe mangakoe ,de boom van het bekennen”. De bladeren van dien boom zijn de representanten van de zielen der menschen: wanneer een dor blad afvalt, sterft een oude van dagen, valt een jong blad af, dan gaat een jong mensch heen.

Bij het water houdt een vrouw de wacht. Ze heet Santahalan. Zij bepaalt of de ziel door mag gaan naar het zielenland of niet. In het laatste geval keert de ziel naar de aarde terug, en herleeft de doode. In het eerste geval wascht ze het gelaat van de ziel, en hierdoor is ze voorgoed van de aarde gescheiden. Het water stroomt door twee leidingen, de eene is van goud, de ander van zilver, maar wie met het water uit de eene leiding, en wie met dat uit de andere wordt gewasschen, wist men niet te zeggen. Gaat de ziel verder, dan komt ze aan een brug, waaronder de hel, nalaka (naraka), is: niet anders dan vuur en warm water, dat uit een bron opborrelt, die kaw'a heet. De zielen van dieven en overspelers (in het algemeen zij die seksueele zonden hebben begaan) vallen er in, doordat de brug zich omdraait.

De andere zielen komen veilig over de brug, en treden zoo de woning van Toempoe den Hemelheer binnen. Van daar uit maken ze tochten naar de aarde, als ze door hun bloedverwanten in nood en moeite worden aangeroepen. Maar degenen die in het vuur zijn gevallen, blijven daar niet lang in. Na 3 of 7 dagen mogen ze er uit, en komen dan ook in het huis van Toempoe. Alleen de zielen van heel slechte menschen worden weggejaagd, en die worden dan booze geesten. 


\section{VERHALEN.}

\section{Ocndoe-ocndoeon anak:ngoenom oea.}

Dagi ko anak aitoe oea, aha madimo toemanjo sagala tinanjo, aha i ngoenomo. Aha mombaoe ala oe kela, montetebimo kela. Mingantokmo, ingoeakmo noe baoe. Tinoa noe aha, ihambamo noe aha noe boeloe' i djalan noe baoe, ka sinolanjo, lamba-lamba inate, ohani laigan noe Langka-langkai.

Sinainjo oetoesnjo momoita apoe i Langkai. Saaba Langkai aitoe maidek hondo ka mabebesi ponoha. Inamba momoita na anak aitoe noe apoe. Konjo noe Langkai aitoe: Lako bebaoe apa na apoe? Konjo noe anak aitoe: Baoe pontoenoean njeekoelit. Konjo moele Langka-langkai aitoe: Lako tokahan mata-mata njeekoelit, ola olontalonta ka okan mata.

Ja, nambamo na anak aitoe, madi bine'annjo apoe. Po'oele sinai noe oetoesnjo, konjo: Lako pe'e poto'i pontoenoean baoe, atinadje ka bine'annjo mae apoe Ka Langkai aitoe tiba Bengkelenjo namba mae. Tinoka aidjo i ponoha, sinampannjomo i oeë. Pinokaoenjo na Bengkelenjo, konjo: Pokajong mae i aloeknjo, ta'ani noe basoeng da koeandjoehakon tede-tede. Saaba antoknjo noandjoehakon, imihinjo boekoenjo bine'njo i anak aha aitoe.

Ja, nambamo i Laigan. Toka i djalan dagi kaoe anoe natibanta $\mathrm{i}$ djalan. Konjo noe anak haha aitoe: Doekoe pe'e, kele, da koealinakon na oenok. Saaba mongoebeti antoknjo, nobolosi noe batang ngapoe.

Langkainjo so'o mae mangala balo. Tinako i laigan konjo noe Bengkelenjo: Imbo da kita mongkan osa-osa mate ponoha. Saaba kidjo i kolononjo kaoe mapoek; ka tinoanjo konjo: Beee pojo, madimo ko antokkoe ponoha.

Saaba anak aitoe nolibamo i oendjoling i biwi oeë. Ka namba na Langkai aitoe Bengkelenjo nolio. Tinoka aitoe i oeë, tinoanjomo na loloeng akaong mae i oeno noe oeë. Konjo: Na komioe silakamo. Ngalapakonnjo talombo ka binoenoenjo, saaba loloeng. Manga-manga kiniopnjomo; ngisiannjomo noe oeë na bihing, sinindanjo, aitoe $\mathrm{i}$ toe'oe oe kaoe. Tinaanjo bobolo'. Ohanimo motoea', na tataemo na anka haha aitoe: Bebeng! Kaoe loeling, po'oele daka!

Manga-manga ilibanjomo. Ohanimo konjo noe anak aitoe: Be' mae na bangko' da koesenaakon i aia. Nolalinakon na bangko', lambalamba pinotabasnjo noe anak. Panjo aitoe dagi djinandji i Bengkelenjo konjo: Saața toedoẹn koeloẹ-koeloẹp, toetoek ka oebạknjo noe doep̣a. 
Saaba tinabas noe anak aiaitoe lamba-lamba nanawoe tinoedoen koeloe-koeloep, boo', ka tinoetoek oe Bengkelenjo noposo-poso na oebak noe langkainjo.

Manga-manga tinoanjo na ohoep oe langkainjo asi, aitoedje ka ia ninoo. Tinoa anak aha aitoe natemo, atinadje ka ilamoen noe aha, binolosakonmo noe aha laigannjo.

\section{Vertaling.}

Het Verhaal van de twee weezen.

Er waren eens twee kinderen; ze hadden geen vader en moeder meer; ze waren weezen; ze makten een tuin van knolvruchten, en ze wiedden het gras weg om in den grond te planten. Toen (de planten) knollen hadden gekregen, werden ze uitgegraven door een varken. Toen de kinderen dit zagen, zetten ze randjau's van dunne bamboe op den weg, dien het varken volgde; dit stak er zich aan (het liep er in), en stierf daarna; dit gebeurde dicht bij het huis van den Ouden Man.

$\mathrm{Zij}$ (het eene meisje) stuurde haar zuster om vuur te vragen. $\mathrm{Nu}$ was die Oude Man heel slecht, die niet anders dan vleesch vrat. $\mathrm{Zij}$ ging, en dat meisje vroeg om vuur. De Oude Man zei: Wat ga je met dat vuur doen? Het kind zei: Om er een njeekoelit (een klein vogeltje) mee te roosteren. De Oude Man zei weer: Dat het rauw gegeten worde, die njeekoelit, trek (den vogel) slechts uit mekaar en eet hem rauw op.

Dat kind ging weg, omdat haar geen vuur werd gegeven. Haar zuster stuurde haar wederom; ze zei: Ga nog eens kennis geven, dat het is om een varken te roosteren, dan zal hij wel vuur geven. Toen gingen de Oude Man samen met de Oude Vrouw er op af. Toen ze bij het wild daar gekomen waren, slachtten ze het bij het water. De Oude Vrouw gaf bevel en zei: Ga naar beneden (naar het water), en zet de draagmand klaar, opdat ik de faeces af late drijven (en gij die in de mand kunt opvangen). Het was echter het vleesch, dat de Oude Man liet afdrijven, en dat door de Oude Vrouw in de mand werd opgeborgen. Aan de kinderen gaven ze alleen de beenderen.

Ze gingen naar huis. Toen ze op den weg kwamen, was daar een boom over den weg gevallen. Het meisje zeide: Buk u wat Grootmoeder, opdat ik de rotan dorens' wat op zij trekke (om te passeeren). Zij nu wiptẹ er hẹt vleesch uit (uit de mand, inplaats van de dorens 
weg te halen, wierp ze het vleesch uit de mand), en deed daarvoor droog hout in de plaats.

De Oude Man bleef achter om bamboe te halen. Toen hij thuis gekomen was, zei de Oude Vrouw : kom, opdat wij tot zat wordens toe alleen maar vleesch eten! Maar daar in de draagmand nu was niets dan vergaan hout. Toen ze dit zag, zei ze: Och arme, mijn vleesch van het wild is er niet!

Intusschen waren de kinderen in een oedjoling-boom aan den kant van het water geklommen. De Oude Man en de Oude Vrouw gingen hen zoeken. Toen ze aan het water gekomen waren, zagen ze het spiegelbeeld (van die meisjes beneden in het water). Hij zei : $\mathrm{Nu}$ is het met jullie gedaan! Toen nam bij zijn speer, en stak naar ze, maar het was maar haar spiegelbeeld. Ten slotte dook hij naar ze (want hij was zijn speer kwijt door die naar het spiegelbeeld te werpen). Bij het duiken liep zijn oor vol water; hij keek op (om het water uit zijn oor te kunnen schudden), en zag daarboven in den top van den boom (de meisjes). Hij hakte den boom met zijn bijl; toen de boom op omvallen stond, zeiden die meisjes: Bebeng! Kaoe loeling (waarschijnlijk ,wonderboom”, want loeli is wondermiddel) wordt weer groot!

Toen (al zijn hakken niets hielp) klom hij èr ten slotte in. Toen hij al dichtbij (de meisjes) was, zeiden de kinderen: Geef ons uw hakmes, opdat we dit (voor u) bewaren. Hij gaf zijn hakmes over, en dadelijk hakten zij (de kinderen) hem (den Ouden Man). Maar hij had een afspraak gemaakt met de Oude Vrouw, zeggende: Zoodra er iets op zijn buik (voorover) valt op den grond, sla dan het hoofd met een hamer stuk.

Toen nu de kinderen hem hadden gehakt, viel hij onniddellijk, en kwam voorover liggende op den grond, boem! Toen tikte de Oude Vrouw er op, en brak het hoofd van den Ouden Man aan stukken.

Zoodra zij (de Oude Vrouw) zag, dat het het gelaat van den Ouden Man was, pleegde ze zelfmoord (de Oude Man had met zijn woorden bedoeld: als een van de meisjes naar beneden valt; de Oude Vrouw merkte te laat, dat ze haar eigen man had gedood). De kinderen zagen dat ze dood waren, begroeven ze en zij betrokken in hun plaats hun woning.

\section{A a n teekeningen.}

Dagi $=$ zijn. $K o$ is een stopwoord met geen bepaalde beteekenis. Aha, pers.vnw. derde persoon meervoud. 
Madimo = niet meer ; het achtervoegsel $m o$ dient als in het Bare'e tot versterking van de beteekenis; of het wil zeggen, dat een handeling is afgeloopen.

Aitoe $=$ dat, aia $=$ dit, vaak komen ze voor in den zin van het lidwoord.

Sagala $=$ met; het gewone voegwoord ,en” is $k a$.

Antok is ,vleesch" tegenover ,beenderen”; mingantok is „vleesch hebben of krijgen", in dezen zin gezegd van de wortelstokken van de katella.

Ingoeak, oeak met infix in, uitgegraven worden.

Tinoa is toa met infix in ,gezien”. Een ander woord voor ,zien” is pia; lako mbatoa is hetzelfde als lako mbapia pia ,ga eens kijken"; potoa mae "laat mij eens kijken"; iets met aandacht bezien is djonohi.

Hamba is randjau, maar hier als werkwoord gebruikt beteekent het randjau's maken.

Boeloe' of lambangan is de bamboe toewi; de echte bamboe waarvan watervaten worden gemaakt, heet balo, de boeloe batoe: awok; de gele bamboe: balo kandala; een soort boeloe betoeng: pehing.

Sinola van sola, Bare'e soela, in iets scherps trappen, en zich daardoor verwonden.

Lamba-lamba, dadelijk rechtstreeks. Tinoka $i$ Tonggon lambalamba $i$ Tamboenan $=$ Toen de Tonggon (tonggol) $\mathrm{kwam}$, ging hij dadelijk door naar Tamboenan (hij bleef hier niet overnachten).

Mate is ,dood"; men voelt er den grondvorm ate in, en maakt hiervan inate ,doodgegaan". Misschien is het ontstaan uit pinate.

Ohane $=$ dichtbij.

Laigan is ,huis"; men heeft ook bonoea, maar dit hoort men zelden; als ik naar het verschil in beteekenis tusschen deze beide woorden vroeg, wist men mij dit niet te zeggen; iemand dacht dat bonoea geen echt Loinangsch 'zou zijn, dus overgenomen.

Kai of langkai is ,grootvader”. Langkai-langkai is de Oude Man, die vaak voorkomt in de verhalen. Het was' onder de Loinangs vroeger ook een titel voor dorpshocfden, in dit geval in den zin van ,groote”.

Sinai van sai, monsai, ,zenden, sturen”. De eene zuster stuurt de ander, maar dit moet uit den zin blijken.

Momoita is vragen; minoita $=$ gevraagd worden; poitaakon akoe $=$ vraag voor mij; pomoitanjo $=$ zijn verzoek; pinoitanjomo $=$ toen hij dit gevraagd had; nomoitamo noe anak aitoe $=$ het kind vroeg.

$S a a b a$ is niet met één woord weer te geven. Als iemand bijvoorbeeld beschuldigd wordt iets weggenomen te hebben, zal hij ant- 
woorden: Saaba misa akoe mongala, ,ik ben het niet, die het heeft genomen". Als men iets vraagt, en de een weet het niet en de ander wel, zegt de eerste: Saaba ii ,hij is 't die het weet”. Saaba aia ,dit is het". Aan het antwoord op een raadsel laat men vaak saaba voorafgaan: Saaba nioc ,het is een kokosboom”.

Maidek ,slecht”.

Hondo ,erg, zeer”.

Mabebasi zegt men van een veelvraat, een slokop.

Ponoha, vleeschspijs, jachtbuit, alle gedierte, dat op het land gevonden wordt. Al het gedierte in zee heet $i k a n$, en alles wat in de rivieren leeft, noemt men ihoo.

Inamba. Mamba (misschien beter maamba) ,gaan, weggaan”; inamba is amba met infix in hier voorgevoegd: weggegaan.

Lako ,gaan", in het Bare'e nog in tadoelako; alleen in dezen vorm gebruikt; het gewone woord voor ,gaan, loopen" is loemadjang.

Baoe ,maken, doen"; ala ka baoe ,neem het mee en maak het”; ala $k a$ obaoe, ,neem het en het worde gemaakt"; nobaoe noe goeroe „door den goeroe gemaakt" binobaoenjo ,toen hij het gemaakt had".

Konjo ,zeggende, hij zeide”. Dit woord wordt alleen in dezen vorm gebruikt. Pinotoinjo, konjo ,hij sprak zeggende”; konjo madi mongkaoho ,hij zegt dat hij niet wil”.

Moele, po'oele ,weder". Ola $=$ slechts.

Lonta, rauw opeten, zoo maar ophappen.

Tokakan. Komioe aia mongkan baoe ,eet gij hier varkensvleesch?” Timbali okan boea aidjo? ,kunnen die vruchten gegeten worden?”; kinannjo ,toen hij het gegeten had"; be' mongkan anak aitoe ,geef dat kind te eten”; pinokan baoe ,varkensvleesch te eten geven”; mongkanakon , iemand iets laten eten; nokan na baoe ,hij at varkensvleesch; $i$ kan, in dezen zin ; ,eet”.

Mata ,rauw”.

Bine'an ,gegeven, gave”, van be' ,geven”; mombe' ,geven”; be'akon ,geef het"; nobe'mo noe goeroe ,,de goeroe heeft het toegestaan”; obe'mo ,sta het maar toe", het worde toegestaan.

$P e^{\prime} e=$ even, een weinig, eerst ; imbo pe'e „kom even, kom eerst”.

Poto' $i=$ kennis geven, doen weten; pinoto'injo ,zij deden weten, gaven kennis".

Atina ,dit”, door dje er achter te voegen wordt er nadruk op gelegd, en krijgt het den zin van ,daarom, dus”.

Bengkele is een oude vrouw (Bare'e bangkele).

Tinoka ,aangekomen" van toka ,aankomen, totaan”. 
Aidjo is de aanwijzer voor iets dat lager ligt: daar beneden; aita voor iets dat hooger ligt: daar boven.

Sinampan van sampan ,slachten”.

Pinokaoenjo van pokaoe ,gelasten”.

Pokajong is naar een lager gelegen punt gaan; pokiita naar een hooger gelegen punt gaan.

Ta'ani $=$ iets gereed zetten met een bepaald doel.

Basoeng is de van sagoebladscheede gemaakte draagmand, die de vrouwen op den rug dragen.

Koeandjoehakon , ik zal laten afdrijven”. Tede $=$ faeces.

Imihinjo $=$ naderhand, daarna, achteraf.

Boekoe $=$ beenderen. Doekoe $=$ bukken (Mal. toendoek $).$ Kaoe $=$ hout, boom.

Djalan en loemadjan worden beide voor ,weg” gebruikt.

Alinakon van ali (Bare'e jali), afhalen wegdoen; ningalinkoemo , ,ik heb het weggedaan”.

Oenok zijn de gedoornde uiteinden van rotanstengels, die vaak over het pad hangen, en de voorbijgangers in de kleeren grijpen, of hen de huid schrammen.

Mongoebeti, een mand, kist en derg. ledigen, den inhoud er uit halen (Bare'e oeati).

Bolosi ,verwisselen, vervangen”; binolosakon „in iemands plaats treden, hem vervangen".

So'o $=$ hier en daar aangaan, om iets achterblijven. Imbo $=$ kom $!$

Osa-osa $=$ tot verzadigens toe. Mate $=$ niet anders dan.

Kolono, iets waarin op den rug gedragen wordt (Bare'e kojo ,op den rug dragen in een mand” enz.); mongkolo ,op den rug dragen”.

Mapoek (Bare'e mapoe), verrot, vergaan, verwaarloosd.

Moliba, in een huis of boom klimmen; ilibanjo, hij beklom iets.

Oendjoling, naam van een mooien hoogen boom.

Bizui $=z i j d e$, kant, lip $i$ bizui $=$ aan den kant van.

Molio ,zoeken”. Loloeng „schaduw, schaduwbeeld”. Akaong ,,beneden".

Sikala van het Maleische tjelaka.

Ngalapakonjo van ala ,nemen”. Talombo $=$ speer.

Binocnoe van boenoe, met de speer steken of werpen.

Manga-manga = langzamerhand, ten langen laatste, ten slotte.

Kiniop van kiop ,duiken”.

Ngisian van isi ,vullen”. Behing ,oor”; wanneer water in 't oor geloopen is, dat er niet uit wil, noemt men dit iligon. 
Sininda van sinda, monsinda ,naar boven kijken”; naar beneden kijken is montiko.

Toe'oe ,uiteinde, top”. Tinaa van taa, montaa ,behakken, een vorm geven".

Motoea' ,omvallen”; tontoea' ,omgevallen”.

Bebeng is een niet te vertalen woord.

Kaoe loeling heb ik met ,wonderboom” vertaald. Loeli is een tegenmiddel, dat men toedient om een mensch of dier iets af te leeren; in 't algemeen een wonderlijk werkend middel. Dat het een wonderlijke boom was, blijkt uit het feit, dat het hout dadelijk weer angroeit, wanneer de Oude Man er een stuk uitgehakt heeft.

Daka „,groot”. Bangko' ,hakmes”.

Oena ,bewaren”; koeoenaakon ,ik zal het (voor u) bewaren”.

I aia ,hier".

Nolalinakon „hij gaf het over, hij deed het verhuizen”; akoe nolalin , ik ben verhuisd”; akoe molalin ,ik verzet het”; pinolalinannjo, zoo noemt men iemand, die vlak na een ander sterft, alsof de ziekte van den een op dien ander is overgegaan.

Pinotabas van tabas, montabas, ,hakken”; tinabasnjo „hij heeft hem gehakt; notabas noe talenga, ,hij werd door den voorvechter gehakt".

Djinandji van djandi ,overeenkomen, beloven”; misschien uit het Maleisch.

Toedoen, aangekomen op een lagere plaats; tinoedoen ,gevallen”.

Koeloc-koeloep, voorover, op den buik liggende; malintibaha, achterover, op den rug liggende.

Toetoek ,tikken, slaan” met een hamer of dergelijk voorwerp; tinoedoek, betikt". Oebak is zoowel ,hoofd" als ,hoofdhaar”.

Doepa „hamer”. Manazoóe ,vallen”. Als men zegt „laat vallen” is dit: toea', dat eigenlijk ,omvallen” beteekent.

Boo', tusschenwerpsel, bang.

Poso ,,gebroken”; naposo-poso ,,aan stukken gebroken”.

Ohoep ,aangezicht, gelaat”.

Asi „dus". Misa anak aha aitoe asi, moanenjo, het waren dus niet de kinderen, maar haar man.

Ninoo van noo ,zelfmoord plegen”.

Lamoen ,begraven”. 


\section{Oendoe-oendoeon anak booene sanggonjo $i$ Taocdo tiba tinanjo ka toemanjo.}

Dagi ko sansinaän tinanjo toemanjo monsai i Taoeda momoita loia. Sata anak aitoe mohoempakmo, kiniapnjo i lampeokannjo, manga-manga tinoemoeno sampe nihoon. Sata soemo aitoe tinoamo noe toemanjo ka tinanjo, atinadje ka binoanjo djodjoon na anak aiaitoe; sata obatong na gong, madimo ohongo; atinadje ka pinodjoonnjomo.

Minto-mintonga ia djodjoong tinokamo na onoeang mokahanda'i montandoek anak aiaitoe, panjo bine'annjo sagin maha, aitoedje ka minsoele na onoeang.

Sasinaän babonjo namba mombebas, nonsahak aitoe. Tinoamo noe anak aitoe binatoeknjomo; notoamo na babonjo ia soemoehang, kabai matisoeloek. Toka-toka i laigan noe babonjo, atinadje ka aha nombaoe lame-lame ka bogandang.

Sata ihongo noe toemanjo tinanjo, ka mamba, pinoto'injo: Boli pe'e mae bagela-gela; anakkoe i Taoedo maisa ilapas na anoe ipiipitoe sampe $\mathrm{i}$ anoe pindoe- pindoeang ipitoen. Panjo tinaloakon $\mathrm{i}$ Taoedo: O mama nene! boli olio mioe na akoe, aiamo akoe na $i$ Taoedo.

Sata soemo aitoe atinadje ka aha minsoesoele, tiba molibos. Ka toka pinapoenjo na laigan ka motojo' tiba aitoe ahamoto langkai bengkele.

\section{Vertaling. \\ Verhaal van het meisje genaamd Taoedo met haar moeder en haar vader.}

Op zekeren dag zonden de moeder en de vader (hun dochter) Taoedo om gember te vragen (zoeken). Toen het kind het had gekregen, wikkelde ze het in (haar sarong) op haar heup. Het ging dadelijk groeien tot het bladeren kreeg. Toen dit zoo was, zagen haar vader en haar moeder het, en daarom brachten ze hun kind ver weg (omdat het verschijnsel, dat zich bij haar had voorgedaan, onheilaanbrengend was); wanneer op de gong geslagen werd, was het (daar) niet te hooren; daar dus moest ze verblijven.

Terwijl ze daar verbleef, kwam er een gemsbuffel, die dat meisje met de horens wilde steken, maar ze gaf hem rijpe pisang, en daarom ging de gemsbuffel terug.

Den volgenden dag ging haar oom jagen, en hij vond wild. Toen 
het kind hem (den oom) zag, volgde ze hem; als haar oom haar zag, ging ze zitten om zich te verbergen. Toen ze aan het huis van haar oom gekomen was, zag haar oom haar, en daarna maakten ze een feest, en sloegen op de trom (uit vreugde over de ontmoeting).

Toen de vader en de moeder dit hoorden, gingen zij er heen, en zeiden (deelden mede): Maakt toch geen leven, want voor ons kind Taoedo zijn de 7 dagen nog niet verstreken tot de tweemaal zeven dagen (op den 3 den, 7 den en 14den [ $2 \times 7]$ dag na de begrafenis worden doodenmalen gehouden; gedurende dien tijd mag geen leven worden gemaakt; de ouders van Taoedo dachten dat hun kind na haar verbanning was gestorven). Maar Taoedo zeide: $O$ vader, moeder, zoekt mij niet, hier ben ik, Taoedo.

Toen dit alles gebeurd was, keerden ze naar huis terug met liefdesmart (ze hadden gedacht, dat het kind dood was, en ze hadden nu verdriet, dat ze het onschuldig hadden weggedaan). Toen ze aangekomen waren, staken ze hun huis in brand, en dit verbrandde samen met den ouden man en de oude vrouw.

\section{A a n te e keningen.}

Sansinaän van sina ,dag, zon”; sansinaän kan beteekenen „op zekeren dag”, maar ook ,,den volgenden dag”.

Loia $=$ gemberwortel. Hoempak $=$ krijgen, vinden.

Kiniapnjo ,ze wikkelde het in”, namelijk in haar sarong, van hiap.

Lampeokan = heup. Tinoemoe van toemoe ,leven, groeien”. Sampe verg. Mal. sampai ,totaan, totdat”.

Nihoon van hoon ,blad”. Soema aitoe ,als dat”, aldus.

Binoa van boa ,brengen, meenemen”.

Djodjoon, herhaling van djoon; madjoon ,ver”.

Sata zal het Mal. serta zijn. In dit stukje komen verscheidene Maleische woorden voor.

Obatong ,,geslagen worden" van een muziekinstrument, van batong.

Ohongo ,te hooren zijn”; koehongo „,ik hoor”; madi mahongo „,niet hoorbaar"; pohongo mae na onjinjo, laat het geluid er van eens hooren”; ia na nohongo, misa akoe na nohongo ,hij heeft het gehoord, ik heb het niet gehoord; ihongomo mioe? ,hebt gijlieden het gehoord (verstaan)?"

Pinodjong, iemand ergens laten verblijven; djinodjong ,ergens verblijven", uit eigen verkiezing.

Minto-mintonga ,,middelerwijl, ondertusschen”. 
Onoeang, de sapi hoetan, gemsbuffel of boschantiloop, Anoa depressicornis.

Mokahanda'i of mongka'oko ,willen, wenschen”.

Montandoek „,met de horens steken”. Sagin maha, rijpe pisang.

Minsoele' „terugkeeren”, ook in den zin van: ergens op één dag heen en weer heengaan; minsoesoele' beteekent alleen terugkeeren; soele'akon anak aitoe ,breng dat kind naar huis terug”; monsoele' „terugbrengen”; sinoele'akonnjomo ,toen hij het teruggebracht had”.

Babo „oom”, zoowel van vaders- als van moederszijde; tante is ka'aka.

Mombebas ,jagen”; men zegt ook mondasoc, met honden jagen, terwijl ,hond" dedeng is.

Monsahak is iets vinden zonder er naar gezocht te hebben, toevallig iets vinden.

Binatoeknjo van batoek „volgen”; oko mombatoek ,gij moet volgen”; pinobatoek ,,iemand een ander laten volgen”.

Soemoehang van soehang ,zitten”; sinoemoehangnjomo akoe ,hi; zette mij neer".

Matisoeloek „zich verbergen”; lako posoeloek ,ga dat verbergen”; posoelockakon ,verberg dat voor (mij)”.

Kabai „misschien”; kabai dagi, kabai madimo, „misschien is er nog, misschien is er niet meer. Als men iets vertelt, wendt men zich tot een ander met de woorden: kabaimo sia'o "misschien is het zoo", is het niet zoo. Kabai mojaa'o ,waar gaat dat soms heen?"

Lame-tame zal wel uit het Maleisch zijn overgenomen (ramairamai).

Bogandang „op den trom, gandang, slaan”.

Boli wordt gebruikt om de verbiedende wijs te vormen.

Bagela-gela „leven, geraas maken”. Maisa „nog niet”.

Ilapas „vrij” van hetgeen er volgt. Voor elken doode namelijk wordt op den 3den, 7 den en 14den dag een feest gevierd. Eerst na het feest van den 14den $(2 \times 7)$ dag heeft men met den doode afgerekend.

Tinaloakon van montalo ,zeggen”. Wanneer iemand de woorden van een ander overbrengt, zegt hij: tinaloakonnjo „hij zegt”.

Molibos moet zijn als het Bare'e mawo ,sterk verlangen, groote begeerte, heimwee", zoodat het zoowel van vreugde als van verdriet kan zijn.

Pinapoenjo ,hij heeft in brand gestoken”; bonoea mopapoemo ,een afgebrand huis".

D1. 86. 
Motojo beteekent eveneens ,afgebrand"; meer nog in den zin van ,verzengd”, of zich aan iets branden.

Ahamota ,zij met z'n allen”.

\section{Oendoe-oendoeon i He'a ka i Balan.}

Saaba i He'a ka i Balan mombaoe ale samian-samian, hi Balan ale oe kela ka toemba, hi He'a lae noe sagin. Djadi aia hi Balan saintoemoeoe nohempos; aia hi He'a moloemba hondo ka boeanjo mandjoo, anoe maha itoeoennjo. Be ka notoa asi i Balan ka lako binoelingnjo. Sata tinoa i He'a soepoe boelingon ka ia mongambi hamba tina'annjo i poeoenjo. Salata noliba a i Balan nokokannjo iwi-iwi, ia nalaloempatmo aita mae nokajong i tano; ka nopasong asi i boetongnjo lamba-lamba inate. Salata tinoa i He'a Balan sinilakamo, ingalanjo ka tinoenoenjo na boetongnjo sampe ihansoen na boekoenjo ka ingalanjo binaoe tilonnjo.

Manga-manga asi ilionjo noe Balan sagaät nokidjo i laigan i He'a; tinoka aitoe labotmo pinanganannjomo noe boekoe aiaitoe. Ja i He'a matisoeloekmo i aloek noe banga noe nioe. Ka i He'a notatae: E paja na ko waweng mioe, saaba tilon atina boekoe-boekoenangmoe. Salata ihongo noe Balan soema aitoe, ka lako ingalanjo na i He'a. Konjo i He'a: Sata opatei mioe na akoe, ola momoita ampoen akoe oo'alin i oeё, sahanjo akoe opapoei da akoe mate asi sabaa' oeë na tanoikoe.

Salata ihongo noe Balan soemo aitoe atinadje ka ingalinnjo $\mathrm{i}$ oeë noe liooe tinoedoen i oeë. Ia notataemo mae: Ja aiadje ka akoe sinanang tanokoe na aia komioe pikok hondo-hondo. Salata inhongo noe Balan soemoe aitoe kan aia notambo $\mathrm{i}$ anoeang da mohoson na monggojok oeë noe liooe. I He'a notambo i olipan, konjo: Salata bekoen monggojokmo lakomoobosik ontoloenjo. Salata onoeang nonggojok ka nabosik asi noe olipan, lamba-lamba onoeang tinaloealoea (of tinooea), po'oelemo noboeke a liooe, lamba-lamba onoeang mate.

\section{Vertaling.}

\section{Het Verhaal van de Schildpad en den Aap.}

Daar waren eens een Schildpad en een Aap, die ieder een tuin aanlegden, de Aap (maakte) een tuin van ketella en suikerriet; de schildpad (maakte) een tuin van pisang. Dat van den Aap nu, zoodra het opgroeide (nl. de katella en het suikerriet), haalde hij het uit 
mekaar; dat van de Schildpad gedijde prachtig, en er kwamen veel rijpe vruchten aan den top (van den boom). Toen de Aap dat zag, ging hij ze (de pinangs) stelen. Toen de Schildpad zag dat alles gestolen werd, maakte hij randjoe's scherp, en plantte die aan den voet (van den boom). Toen de Aap er in geklommen was, en hij alles had opgegeten, sprong hij daarboven, en sprong op den grond, (de randjoe's ) doorstaken hem en hij was dadelijk dood. Toen de Schildpad zag dat den Aap een ongeluk getroffen had, nam hij hem en roosterde zijn lichaam, zoodat het verteerde, zijn beenderen nam hij, en daarvan maakte hij kalk.

Ondertusschen zochten eenige apen hem (hun makker) daarginds in het huis van de Schildpad; toen zij daar gekomen waren, reikte zij (de Schildpad) de sirih-pinang van die beenderen toe. De Schilpad had zich onder en kokosdop verborgen. En de S. zeide: Och arme, wat zijt gij toch dom, want de kalk is uw gebeente. Zoodra de apen dit hoorden, gingen ze en haalden de Schildpad. De S. zeide: Als ge mij wilt dooden, vraag ik vergiffenis, dat ik in het water geworpen worde (d.i. wil mij dan niet in het water werpen), maar verbrandt mij liever, opdat ik sterve, want het water is mijn land.

Toen de apen dit hoorden, brachten ze haar over in het water van een vijver, en wierpen haar in het water. Toen zei zij (de Schildpad): $\mathrm{Ja}$, zoo is het goed, ik heb het prettig in mijn land hier; gijlieden zijt uitermate onnoozel. Toen de apen dit hoorden, huurden zij een sterken gemsbuffel om het water uit den vijver op te drinken. De Schildpad huurde een duizendpoot en zei: Als de oude aan het drinken is, ga hem dan in de testes steken. Terwijl de gemsbuffel het water dronk, stak de duizendpoot hem, en toen ging de gemsbuffel dadelijk aan het braken, en toen werd de vijver wederom vol, en de gemsbuffel stierf daarna.

\section{Het Verhaal van de Hemelnimf.}

Er waren eens zeven hemelnimfen (mian bidjodjali, Mal. bidadari), die naar de aarde kwamen gevlogen om er in een poel te baden. Dat zag Ade Banggai, en hij besloot om een van die nimfen te vangen. Daarom maakte hij een haak (oenok) van rotan klaar, en verborg zich daarmee aan den kant van den vijver. Niet lang daarna kwamen de hemelnimfen; zij legden hun bekleeding (baloelang) op den waterkant, en gingen baden. Ade Banggai in zijn schuilplaats haakte de bekleeding van de jongste hemelnimf vast, en trok die naar zich toe. 
Nadat de hemelnimfen gebaad hadden, kwamen ze weer op het land, en trokken hun bekleeding aan. De jongste zocht naar haar omhulsel, maar kon het niet vinden. De zes anderen wilden haar toen met zich naar den hemel dragen, maar dat ging niet, en daarom moest zij achtergelaten worden.

Toen de zes hemelnimfen vertrokken waren, kwam Ade Banggai te voorschijn, greep het achtergebleven meisje, en droeg haar naar zijn woning. Het meisje weende voortdurend, maar Ade Banggai troostte haar, zoodat zij er in toestemde zijn vrouw te worden. Haar omhulsel intusschen verborg hij in een fluit, die hij in het dak stak.

$\mathrm{Na}$ eenigen tijd beviel de hemelnimf van een dochter; maar het kind huilde voortdurend. Men riep er een priester bij, en deze zeide: Wanneer Ade Banggai een prauw gaat maken, zal het kind zeker ophouden met huilen. De vader ging nu naar het strand, hakte een boom om en begon een prauw te maken.

Intusschen bleef het kind, dat den naam van Manoek loeling gekregen had, maar steeds schreien. Om het wat af te leiden, lichtte de moeder telkens een stuk van de dakbedekking op, zoodat het zonlicht door de opening naar binnen viel. Terwijl ze dit deed, viel de fluit naar beneden, die Ade Banggai in het dak had gestoken. De vrouw nam het speeltuig op, en wilde er op blazen, maar er kwam geen geluid uit. Daarom spleet zij de fluit om te zien wat er in was, dat ze geen geluid gaf. En daar vond ze haar omhulsel! Ze trekt het aan, en voelt dadelijk, dat ze weer naar den hemel kan opstijgen.

$\mathrm{Nu}$ ving ze een hoen, bereidde dat, kookte rijst, en zette alles klaar voor haar man, opdat hij te eten zou hebben als hij thuis kwam, Daarna nam ze haar kind Manoek loeling in de armen, en hield haar kalkbusje in de hand. Toen vloog ze op naar het strand, waar Ade Banggai bezig was de prauw te maken. Toen ze boven hem gekomen was, liet ze haar kalkbus vallen, en die kwam vlak vóór Ade Banggai neer. $\mathrm{Hij}$ nam het ding op, en zag dat het de kalkbus van zijn vrouw was. Toen keek hij op om te zien waar deze vandaan gekomen was, en toen zag hij zijn vrouw met zijn dochter hemelwaarts vliegen. Hij riep: Ga niet weg! Kom terug! Maar de vrouw vloog voort.

Ade Banggai liet zijn prauw in de steek, en ging naar huis. Daar zag hij den maaltijd, die zijn vrouw voor hem klaar gemaakt had. $\mathrm{Hij}$ at dus eerst, en toen ging hij uit om een middel te zoeken om ook in den hemel te komen. Hij kwam bij een oewe bokoe (soort 
rotan), en zeide: He, oewe bokoe, kan je mij misschien tot den hemel (lajano) brengen? De rotan antwoordde: Ik kan zoover niet reiken, maar vraag het aan de oewe tabang (een andere soort rotan), die kan er misschien wel komen. Ade Banggai ging naar de oewe tabang en vroeg: Zeg, oewe tabang, kan je wel tot aan het hemelruim komen? De oewe tabang antwoordde: Neen, zoover kan ik niet reiken, maar vraag het eens aan de oezve sampang (weer een andere soort rotan). Ade Banggai deed zoo, maar ook de oewe sampang kon hem niet naar den hemel brengen, en verwees hem weer naar een andere soort rotan. Dit gebeurde zoo eenige malen.

Eindelijk kwam Ade Banggai bij de kohioehoeng, een zeer dikke soort rotan. Hij vroeg: Zeg, kohioehoeng, kan jij tot aan den hemel komen en mij daar brengen? Maar de rotan antwoordde niet. Eerst nadat Ade Banggai driemaal zijn vraag herhaald had, antwoordde de kohioehoeng: Dat is goed, ik zal je naar den hemel brengen; sla een bamboe pen in mijn top, en ga daarop staan (in dien tijd had de rotan nog geen dorens). De rotan zei nog: Al sla ik over naar het Noorden, Zuiden, Oosten of Westen, je moet mij niet loslaten. Toen sloeg Ade Banggai een bamboe pen in het topeinde van den rotan, en ging daarop staan. Dadelijk strekte de rotan zich naar boven uit; hij ging hoe langer hoe hooger; hij slingerde erg, nu eens naar dezen kant, dan naar die zijde; maar Ade Banggai liet hem niet los.

$\mathrm{Na}$ verloop van enkele nachten was de rotan aan het gat gekomen, dat toegang geeft tot den hemel; hij haakte het topeinde aan het gat vast, en Ade Banggai trad den hemel binnen. Daar zag hij een dorp. Hij ging er heen, en bond het topeinde van den rotan aan de paal van het huis. Toen vroeg hij waar de moeder van Manoek loeling woonde, en men wees hem haar huis aan. Hij klom er in, en zijn vrouw was zeer verbaasd hem te zien. $\mathrm{Zij}$ vroeg: Hoe kom jij hier? Hij antwoordde: De rotan heeft mij gebracht. Daarna reikte de vrouw aan Ade Banggai sirih-pinang toe, maar zij waarschuwde hem: Pruim geen pinang, die al een poos geleden is doorgesneden, want dan worden wij hemellingen slangen; je moet alleen versch doorgesneden pinang pruimen. Ade Banggai zag ook, dat de sterren de oogen zijn van de hemelbewoners.

In zekeren nacht wilde Ade Banggai een sirihpruim nemen, maar hij lette er niet op, of hij versch doorgesneden pinang nam. Toen gebeurde het, dat hij pinang pruimde, die al een poos geleden was doorgesneden. Zoodra hij dit gedaan had, veranderden al de bewoners van dat huis in slangen, behalve hij zelf. Er kwam een kleine slang 
naar hem toe, die hakte hij de punt van de staart af, en deed het dier daarna onder een deksel. Toen het dag geworden was, werden de slangen weer menschen, maar zijn dochter Manoek loeling huilde voortdurend, omdat ze een wond had; zij was de kleine slang van wie Ade Banggai de staart had afgekapt.

Ade Banggai voelde zich niet op zijn gemak in den hemel, en hij wilde naar de aarde terug. Maar op dien morgen ging een hemelling onder het huis vegen, en hij zag den rotan, dien Ade Banggai aan den paal had vastgebonden. Hij zei: Wat is dat voor onkruid, en hij hakte den rotan los, zoodat deze op de aarde neerstortte, en tot een berg werd, de berg Lokait.

Ade Banggai was nu erg verdrietig, dat hij niet meer naar de aarde terug kon. Maar toen kwam de Njeekoelit tot hem. Dit was toen nog een groote vogel ${ }^{1}$ ). Ade Banggai vroeg hem: Njeekoelit, wil je mij naar de aarde terugbrengen!

De vogel zeide: Wat zal je mij als loon geven, als ik je terugbreng? Ade Banggai antwoordde: Dan zal ik een groot rijstveld voor je aanleggen. Dit vond de vogel goed. Ade Banggai ging nu aan de pooten van den vogel hangen, en deze droeg hem terug naar de aarde. Maar toen ze dicht bij de aarde waren gekomen kon Ade Banggai zich niet meer vasthouden; hij liet los en stortte naar beneden. Hij kwam in een waringin terecht, en daar bleef hij wonen, tot hij in een aap veranderde, en aan alle apen het aanzijn gaf. En de vogel kwam met zoo'n kracht in een alang-alangveld terecht, dat het de pooten bezeerde aan de scherpe uitspruitsels van deze planten, zoodat hij niet meer in staat was naar den hemel terug te keeren. Hij bleef dus op aarde, waar hij steeds in grootte afnam, tot hij het kleine vogeltje van heden werd.

\section{Het Verhaal van de zes Dieren, die gaan visschen.}

De hambaoe (karbouw - deze komt in het bovenland niet voor, en in de strandstreek vindt men niet veel van deze dieren; op enkele plaatsen wordt hij alleen in verwilderden staat gevonden, een bewijs dat de voormalige eigenaren niet meer in staat zijn geweest deze dieren te verzorgen en te weiden - het rund, het paard en de bok zijn alle dieren, waarmee de Loinangs pas in later tijd bekend zijn

1) De njeckoelit - in Poso djeekoeli - is een mooi blauw vogeltje, dat graag zijn nest tusschen de rijst maakt, maar dat aan het gewas zelf geenerlei kwaad doet. Zoowel de Posoër als de Loinang beschouwt dit diertje als de drager van de rijstziel. 
geworden. Men had vijf groote dieren noodig om deze tegenover den kleinen spookaap te stellen, en daar men niet genoeg groote dieren uit eigen omgeving kende, zocht men ze daarbuiten. Opmerkelijk is, dat naast de onoeang niet het varken is genoemd) groef een massa toeba-wortel (Loin. toezva, Derris elliptica, waarvan men den wortel murw slaat en daarna in het water spoelt, zoodat het bedwelmende sap uit de plant zich met het water vermengt, en de visschen bedwelmt, zoodat ze boven komen drijven), en bond dit in zes bossen. Eén van deze vrachten nam hij op den rug, en begaf zich op weg. Het duurde niet lang of de buffel ontmoette een rund. Hij sprak het toe en zei: Laten we samen gaan visschen. Het rund stemde toe. Ga dan een vracht tocba-wortel halen, zei de buffel.

Ze waren nog niet lang op weg, toen ze het paard vonden. Waar gaan jullie naar toe? vroeg het paard. Wij gaan visschen zei de karbouw, als ge met ons wilt gaan, ga dan een bos toeba-wortel halen. Het paard nam dus een vracht op den rug, en toen gingen ze met hun drieën verder.

Een eind verder zagen ze den bok. Ook deze werd uitgenoodigd mee te gaan en hij droeg zijn vracht toeba-wortel. Weer een eind verder zagen ze den gemsbuffel (onoeang); deze nam de vijfde bos op den rug, en ging mee.

Ten slotte kwamen ze den spookaap (bonsing) tegen. Deze vroeg ook om mee te mogen gaan. Eigenlijk wilden de andere dieren niet dat hij meeging, maar omdat er toch nog een vracht toeba-wortel over was, stonden ze het toe, mits de spookaap zijn eigen pak droeg.

Aan de groote rivier gekomen, maakten ze een hut, en daarna bewerkten ze een deel van de rivier met den toeba-wortel. Ze vingen een massa visschen, wel twee manden vol. Toen maakten ze een groot vuur en rookten (montapa) de visch.

Den volgenden morgen zouden ze weer gaan visschen. Wie zal op de visch passen? vroegen ze. Dat zal ik doen, zei de karbouw. Dus gingen de vijf anderen visschen, en de karbouw bleef in de hut. De vijf waren nog niet lang weg, toen het ging regenen, terwijl de zon scheen, en in dien regen met zonneschijn kwam de boschgeest Lambeboeang. Geef mij van je visch, zei de geest. Die geef ik niet, antwoordde de karbouw. Laat er ons dan om vechten, hernam Lambeboeang, als ik het win, eet ik alle visch op. Toen vochten ze samen, maar de boschgeest overwon den buffel, en toen at hij alles op.

Toen de andere dieren thuiskwamen, waren ze erg verdrietig, dat de visch op was, maar de buffel vertelde wat er was gebeurd. Den 
volgenden dag bleef het rund waken, maar ook dit moest het tegen den boschgeest afleggen. En zoo ging het ook met het paard, de bok en de onoeang. De dieren weenden, en zeiden: $\mathrm{Nu}$ zullen we zonder visch naar huis terug moeten keeren! Maar de spookaap zei: Gaat jullie maar visschen, en ik zal maken, dat Lambeboeang niets van de visch wegneemt. De andere dieren geloofden hem niet, maar ze gingen toch uit visschen, den spookaap bij de visch achterlatende.

Het duurde niet lang, of er kwam weer regen met zonneschijn, en toen verscheen de boschgeest. Geef mij van je visch, zei hij. Ik geef niet, antwoordde de spookaap. Wilde jij met mij vechten? riep de boschgeest verbaasd. Ja, zei de spookaap. Toen Lambeboeang hem wilde pakken, sprong de spookaap steeds maar heen en weer, dan in de boomen, dan weer op den grond. De boschgeest was een en al verbazing over die vlugheid. Als ik eens zoo vlug was! riep hij. Zeg, spookaap, welke medicijn heeft je zoo vlug gemaakt? Wil je die aan mij geven, opdat ik net zoo zal kunnen springen als jij? Als je mij dit middel geeft, zal ik je alles schenken wat je hebben wilt.

Dat is goed, zei de spookaap, maar de reden waarom ik zoo vlug ben, is omdat ik zoo'n kleinen buik heb. Ik kan je wel een kleinen buik bezorgen, maar dat doet pijn. - Dat komt er niets op aan, zei de boschgeest verheugd. Toen bond de spookaap Lambeboeang met rotan aan een dikken boom vast, zoodat de boschgeest en de boom één waren. Toen maakte de spookaap een wig, en sloeg die tusschen de rotan en den boom, zoodat de rotan den buik van den boschgeest insnoerde. Deze nu begon te schreeuwen: au! au! De spookaap hield op met op de wig te slaan, en zei: Ik heb je immers gezegd, dat het pijn zou doen! Maar als je niet meer vlug wilt worden, maak ik den rotan los. - Neen, neen, riep de geest, ga maar door, als ik maar zoo vlug word als gij.

Toen sloeg de spookaap weer op de wig, zoodat Lambeboeang gilde van de pijn. Maar nu bleef de spookaap doorslaan, zoodat de buik van den geest berstte. Daaruit ontstond de regenboog (tandalo).

Toen de andere dieren 's avonds thuis kwamen, waren ze erg blij dat ze hun visch behouden hadden, en dat de boschgeest dood was. Ze keerden met veel visch naar huis terug.

\section{Het Verhaal van den slaaf die Koning werd.}

Er was eens een vorst die een slaaf had, die Langgoela heette. En hij had ook een dochter, die bijna volwassen was; en deze heette 
Oedoe. Toen de vorst weer een kind gekregen had, wilde hij het wijdingsfeest voor dat kind vieren (malapa' boombong). Daarom gelastte hij Langgoela om visch te gaan vangen om als toespijs te dienen op het feest. Langgoela vroeg nu om een metgezel, want hij zeide: Ik kan niet alleen gaan. - Daar er niemand anders was, zei de vorst tot zijn dochter: Oedoe, vergezel jij Langgoela! Dus gingen die twee weg om te visschen.

Toen ze aan het water gekomen waren, deed L. geen aas aan zijn hengel, zoodat geen visch wilde bijten, en hij niets ving. Tegen den avond zei L.: Hoe zou het toch komen, Oedoe, dat we heelemaal geen visch gevangen hebben? Het heeft geen nut om naar huis terug te keeren. Laat ons in de hut overnachten, en dan zal ik naar het vogelgeluid gaan luisteren (mompihongoi), of ze ons voor morgen geluk voorspellen; want als de koekaoe viermalen roept, zullen we zeker visch krijgen.

Toen het donker geworden was, zei L. tot Oedoe: Oedoe, ik ga mijn behoefte doen, en jij moet goed op het vogelgeluid letten. $\mathrm{L}$. verwijderde zich en klom in een boom. Vandaar uit riep hij: Kakoea, kakoca, kakoea, patitoedoe na $i$ Langgoela hi Oedoe (laat Langgoela en Oedoe op elkaar komen). Een poos daarna kwam L. in de hut terug, en vroeg: Wat heeft de koekaoe geroepen? Oedoe zei : De koekaoe heeft geroepen: koekaoe, koekaoe, koekaoe, laat L. en O. op elkaar komen. Toen zei L.: Hoe moet dat nu, laten we maar doen wat de vogel gezegd heeft.

Den volgenden dag ving $L$. veel visch, omdat hij aas aan zijn hengel deed. Toen zij thuis gekomen waren, vertelde Oedoe alles wat gebeurd was aan haar vader. De vorst was heel boos, en hij zei, dat L. in zee verdronken moest worden. Daarom liet hij een groote mand (kalandjang) van rotan maken, en daarin werd L. opgesloten. Men liet de mand zoo op den weg staan, want de menschen gingen eerst eten, voordat ze L. in zee zouden gaan werpen.

Intusschen kwam iemand voorbij, die aan L. vroeg: Wat doe je hier? L. antwoordde: Ik zit hier te wachten op mijn overleden bloedverwanten, die mij zullen komen ontmoeten. Als men zoo in deze mand zit, ziet men ze allen. - De voorbijganger vroeg: Is dat heusch waar? - Werkelijk waar, antwoordde L. - Laat mij er dan ook eens in, vroeg de voorbijganger. L. antwoordde: Dat is goed, maak de mand maar open. - Toen de mand open was, kwam L. er uit, en de voorbijganger nam zijn plaats in.

Toen de menschen gegeten hadden, kwamen ze terug, lichtten de 
mand op, en zeiden: Nu zullen we Langgoela in zee werpen. De vreemdeling begon te schreeuwen en riep: Ik ben Langgoela niet! Maar de menschen geloofden het niet, en lachten hem uit. En zoo werd de vreemdeling verdronken in de plaats van Langgoela.

Langgoela ging naar het bosch en jaagde op gemsbuffels en varkens, waarvan hij het vleesch rookte. Ook verzamelde hij aan het zeestrand veel schelpdieren, en dit alles droeg hij naar het dorp. Daar maakte hij van het vleesch vele pakjes in bladeren gewikkeld, en zwaar bevracht trad hij het dorp binnen. Ieder die Langgoela zag, was verwonderd over zijn terugkeer. Toen de vorst hoorde dat L. er was, liet hij hem bij zich komen, en vroeg hem naar de reden van zijn terugkeer. L. zei: Toen ik op den bodem van de zee was aangekomen, vond ik daar een groot dorp, waar uwe ouders en grootouders woonden. Er was volop van alles, en ik was er graag gebleven. Maar uw vader en uw moeder zeiden, dat ik naar de aarde terug moest gaan om $u$ geschenken te brengen. En toen de andere afgestorvenen dit hoorden, gaven ze mij ook allerlei geschenken mee.

Daarna ging $\mathrm{L}$. aan het uitdeelen van de geschenken, de pakjes vleesch en schelpdieren die hij had gemaakt.

De vorst dacht maar steeds na over het verhaal van L., totdat de lust groot in hem werd om zijn gestorven familie op den bodem der zee te gaan bezoeken. Toen hij zijn voornemen te kennen had gegeven, waren er wel 100 menschen die met hem mee wilden in de zee om hun afgestorvenen te ontmoeten. Ieder makte voor zich een mand, en liet er zich in opsluiten. Met een groote prauw, waarin wel 10 manden tegelijk gingen, werden ze in zee gebracht, en daarin geworpen. L. zei tot de overige menschen: De vorst heeft mij gezegd, dat als hij het goed had op den bodem der zee, hij niet meer naar de aarde terug zou keeren, en dat ik in dat geval radja moest worden. - Toen de vorst dan ook niet terugkeerde, werd Langgoela vorst en hij huwde met Oedoe.

\section{Het Verhaal van den weerwolf Kokosili.}

Er was een oude man die Kokosili heette. Hij had een zoon. Eens staken vader en zoon over naar een eiland, waar veel bijen waren om er was te verzamelen, en die dan te verkoopen. Ze zochten een geruimen tijd naar was, zoodat ze er heel wat van in hun hut verzamelden.

Toen werd Kokosili ziek, en omdat hij zich koud voelde, sliep 
hij met de voeten naar het haardvuur gekeerd (dit heet mananengke van tengke ,been, voet”; met den rug naar het vuur gekeerd liggen heet mananikoe van tikoe, het grondwoord van het Bare'e talikoe „rug”). De zoon ging er dus alleen op uit om was te zoeken. Toen hij tegen den avond weer aan de hut kwam, zag hij dat de voeten van zijn vader aan het branden waren. De zoon riep uit: Vader, voel je niet, dat je voeten aan het branden zijn! Waarom trekt gij ze niet van het vuur terug? - De vader antwoordde: Het is lekker warm zoo. - De zoon goot water over het vuur aan de voeten van zijn vader; maar hoe meer water hij er over stortte, hoe grooter de vlammen werden.

Den volgenden dag ging de zoon weer was zoeken, en toen hij in de hut terugkwam, zag hij, dat het vuur tot aan de kuiten van zijn vader had voortgevreten. Hij lichtte zijn vader op, en wilde hem van het vuur wegtrekken, maar deze zeide: Laat maar, het is zoo lekker warm! - Hij goot weer water op het vuur, maar dit vlamde hiervan nog meer op.

Den volgenden dag ging de zoon er weer op uit, en thuis gekomen vond hij het vuur opgeklommen tot aan de knie van zijn vader. Zijn vader voelde er niets van, en zei aldoor maar: Zoo is het lekker warm! - Als de zoon thuis was, bleef het vuur op dezelfde hoogte, maar als hij weggegaan was om te zoeken, klom het op. Toen hij weer thuis kwam, was het vuur tot aan zijn billen gekomen. Den volgenden dag tot aan zijn navel, den volgenden dag tot aan zijn borst, en den volgenden dag was alleen het hoofd nog over. Toen zei de vader: $\mathrm{Nu}$ voel ik mij pas heelemaal genezen, geef mij nu sirih-pinang te pruimen. Maar de zoon was erg bang voor het hoofd, want hij zag dat de ooren lang waren geworden.

$\mathrm{Nu}$ dacht de zoon: ik zal wegloopen. Daarom zei hij: Blijf maar hier, vader, dan zal ik de prauw in orde maken. Toen zei hij tot zijn vader: De prauw kan niet meer in orde worden gemaakt. Maar dat was niet waar, de zoon wilde slechts vluchten. De vader zei : Je moet de prauw in orde maken, dan kunnen we vertrekken. De zoon verzamelde nu heimelijk zijn kleeren, en daarmee ging hij naar het strand; al de was liet hij achter, maar hij zei tot zijn vader: Als de prauw klaar is, kom ik de was halen. Toen hij aan het zeestrand was gekomen, ging hij in de prauw, en roeide zoo hard hij kon weg.

In zijn dorp gekomen, riep hij alle menschen toe: Vooruit, menschen, neemt allen de vlucht, want mijn vader is een weerwolf 
geworden. Zoo verlieten dan alle menschen het dorp, zoodat het leeg werd.

Intusschen riep de vader zijn zoon, maar deze kwam niet. Toen wipte het hoofd op, en vloog naar het strand. Het vond daar de prauw niet meer, en daarom vloog het naar den vasten wal, en kwam in zijn dorp aan. Toen hij hier niemand aantrof, riep het hoofd: Waar zijn jullie allen gebleven?? - Kokosili vloog in zijn huis, en zette zich op een koperen bord (doclang) neer, en daar ging het hoofd van allerlei zingen.

De kinderen van de gevluchte menschen dachten aan het suikerriet, dat op het erf naast hun huis groeide, en daarom kwamen ze in het dorp terug om daarvan te halen. Ze hoorden het hoofd in huis zingen, en toen het suikerriet bij het afbreken kraakte, sprong het hoofd naar beneden. De kinderen vluchtten, en het hoofd rolde hen achterna, maar omdat de kinderen zigzagsgewijs liepen, kon het hoofd hen niet krijgen, en daarom keerde het naar huis terug.

Op zekeren dag kwamen zes jagers in dat verlaten dorp. Slechts in één huis hoorden ze zingen. De mannen vroegen van den grond af : Mogen we boven komen? - Het hoofd antwoordde: Komt boven, maar steekt eerst uwe speren op een rij in den grond vóór het huis, en terwijl gij boven komt, ga ik sirih voor $\mathrm{u}$ halen. - Het hoofd echter ging geen sirih halen, maar het verborg zich in het kamertje.

De jagers deden zooals hun gezegd was, en toen riep het hoofd: Komt boven om sirih te pruimen! - De jagers klommen in huis, en zetten zich neer. Toen sprong het hoofd te voorschijn. De jagers schrikten geweldig, en sprongen naar beneden; maar ze vielen in hun speren en stierven allen. Het hoofd ging toen in de deuropening zitten, en zei allerlei spreuken op. Daardoor scheidden de hoofden van de zes jagers zich van hun lichamen, en die hoofden sprongen voort, en ze bleven maar steeds bij het hoofd van Kokosili. Toen werd dat dorp een dorp van weerwolven, en niemand durfde er meer voorbijgaan.

\section{Het Verhaal van Boenga poete', „Witbloem”.}

Boenga poete' was een vrouw, en haar man heette Sasoendjawa. Toen Boenga poete' zwanger was, reisde ze met haar man naar een ander dorp. Onderweg kwamen ze aan een mangga-boom, en daar Boenga poete' de lusten van zwangeren had, wilde ze van de onrijpe vruchten van den boom eten. Ze zei dus tot Sasoendjawa: Zeg, man, 
klim in den boom, en haal voor mij van de vruchten. De man stemde er in toe, en klom in den boom. Terwijl hij boven in den boom zat, kwam een vrouwelijke booze geest, Tongkoiwi geheeten, bij Boenga poete', en bood aan haar te luizen. Maar terwijl ze dit deed, en Boenga poete's hoofd op haar dij lag, stak ze haar de oogen uit, en wierp haar lichaam in de wildernis. Daarna deed Tongkoiwi zich voor als Boenga poete'. Ze slikte een steen in om haar buik te doen opzetten, opdat men zou zeggen, dat ze zwanger was. Toen Sasoendjawa weer beneden gekomen was, merkte hij niets van de verwisseling, en hij zette de reis met Tongkoiwi voort, tot ze aan het dorp Datoe djawa kwamen, waar Sasoendjawa radja geworden was.

$\mathrm{Na}$ verloop van eenigen tijd werd Tongkoiwi werkelijk zwanger, maar toen haar kind geboren werd, kleefde de ingeslikte steen aan de kuit van het kind, en daarom kreeg het den naam van Takin boitan ,,aan wien de slijpsteen kleeft”.

Intusschen kroop de blinde Boenga poete' in het bosch rond, en ze was heel bedroefd. Toen kwam een muis tot haar, die zeide: Waarom ben je bedroefd? Boenga poete' antwoordde: Ik heb het zoo koud. - De muis bracht haar vuur, en Boenga poete' legde dit bij het hout, dat ze al tastende bijeenvergaard had, en nu kon ze zich warmen. Maar nog was ze bedroefd. Toen vroeg de muis weer: Waarom heb je verdriet? En Boenga poete' antwoordde: Omdat ik naakt ben. - Toen stal de muis een sarong, en sleepte die naar Boenga poete'. Ten laatste werd haar kind geboren. De muis onderhield haar, want telkens bracht zij haar voedsel, dat ze gestolen had.

De jongen groeide snel op. Op zekeren dag vroeg hij aan zijn moeder: Moeder, maak mij een blaasroer. - Boenga poete' antwoordde: Haal mij een stuk bamboe, dan zal ik een blaasroer voor je maken. - De jongen haalde een bamboe, en de moeder maakte een blaasroer. Alles waarop de jongen schoot, raakte hij ook. Wanneer hij een vogel geschoten had, haalde hij de oogen van het dier er uit, en deed die in de oogholten van zijn moeder; maar ze pasten niet, en daarom wierp hij ze weer weg. Als hij een cuscus geschoten had, deed hij de oogen van het dier in de oogkassen van zijn moeder; maar ze pasten niet, en daarom gooide hij ze weer weg. Zoo deed hij met de oogen van alle dieren, die hij schoot.

Op zijn zwerftochten kwam de jongen ook eens in de kampong Datoe djawa. Daar speelden kinderen, en hij speelde met hen mee. Onder dat huis was een kippenest, waarin een kip op haar eieren aan 
het broeden was. Hij nam een der eieren en sprak het aldus toe: $\mathrm{He}$, ei, als ge opengaat, komt er dan een dappere haan uit je? - Maar het ei hield zich stil. Zoo deed hij ook met het tweede en derde. Het vierde eindelijk gaf antwoord. Dit zei : sik! sik! Dit ei nam hij mee, en legde het naast de hut van zijn moeder onder een kokosdop.

Eens op een dag klom hij in het huis van zijn vader, maar hij wist niet dat het zijn vader was. Hij wilde een sirihpruim nemen, en hij deed daarom de sirihdoos van Tongkoiwi open. Het kalkbusje was leeg, en daarom zocht hij in de doos, of er soms een pakje kalk in was. Hij vond een pakje, deed dit open, en zie, dat waren de oogen van zijn moeder. Hij liep gauw met die oogen weg, wies ze in helder water, en toen deed hij ze in de oogkassen zijner moeder.

Intusschen was uit het ei een witte haan gekomen. Met dit dier ging de zoon van Boenga poete' naar het dorp van zijn vader, en hij liet zijn vogel vechten tegen de andere hanen van het dorp. Telkens verloren de eigenaren der hanen het tegen hem. Al de winst die hij hierdoor kreeg, bracht hij aan zijn moeder. Deze liet van al dien rijkdom een mooi huis bouwen met vele fraaie voorwerpen er in. Maar nooit zagen de menschen welken weg hij volgde, als hij van zijne moeder kwam, of naar haar terugkeerde.

Ten slotte bezaten de menschen niets meer om te verwedden, en daarom zetten ze zichzelf op het spel: Wanneer hun haan het won van dien van Boenga poete's zoon, dan zou deze hun slaaf worden. Maar won de witte haan, dan zouden zij de slaven van Boenga poete's zoon worden. En zie, alle inwoners van dat dorp werden zijne slaven.

Toen zei de radja tot Boenga poete's zoon: $\mathrm{Nu}$ zal mijn haan met dien van jou vechten; als ik win, neem ik jou en alles wat je bezit; als gij wint, neemt gij mij en alles wat ik bezit. - De witte haan won het weer. Maar de radja werd boos, en sloeg den jongen onder zijn huis dood, en den haan bond hij aan een poot aan een paal van zijn woning. De haan nu zoog met zijn snavel al het bloed van den grond op, dat uit de wond van Boenga poete's zoon was gevloeid, en bracht het terug in de wond. Tegen den avond kraaide de haan: Toetoehoeooe, oeminanga noe Datoe djawa, binalamo, toemanjo nosipateimo anaknjo „Kukeleku, in de strandkampong Datoe djawa is er een onheil geschied, de vader heeft zijn kind gedood". Den heelen nacht door bracht hij het bloed in de wond van Boenga poete's zoon terug, en streek er dan met. den vleugel over.

Tegen het aanbreken van den morgen leefde de jongen; hij maakte zijn haan los, en keerde er mede naar zijn moeder terug. Deze had 
gedurende de afwezigheid van haar zoon voortdurend geweend. De zoon maakte nu een mooi huis voor zijn moeder. Toen sloot hij de oogen en zei: Als ik werkelijk een zoon van Sasoendjawa ben, dan zal er een heele kampong met veel menschen zijn, als ik de oogen weer opendoe. - En werkelijk, daar was een kampong met veel menschen.

Intusschen had Sasoendjawa van de macht en het aanzien van den jongen vorst gehoord, en daarom ging hij een bezoek aan het nieuwe dorp brengen om kennis te maken. Toen Sasoendjawa gekomen was, vertelde Boenga poete's zoon hem wat Tongkoiwi met Boenga poete' had gedaan. Sasoendjawa keerde naar huis terug, en verbrandde Tongkoiwi en haar zoon. Uit hun asch groeide de baloeangin, een soort groente (Mal. bajam); wanneer men deze groente kookt, pruttelt ze nog steeds in den pot: Wak, wak, akoe i Tongkoizei „Wak, wak, ik ben Tongkoiwi".

Sasoendjawa vroeg vergiffenis, en toen leefde hij weer samen met Boenga poete'. Toen Sasoendjawa gestorven was, volgde. zijn zoon hem op.

\section{Het Verhaal van Pompoelion.}

Er was eens een radja, die Sasoendjawa heette. Hij kreeg geen kinderen, en daarvan had hij veel verdriet. Ten slotte werd zijn vrouw toch zwanger, maar toen zij van een dochter bevallen was, stierf de vader. De moeder gaf het kind den naam van Pompoelion. Ze legde haar dochter in een wieg, en bond het daarin vast met allerlei kleurige draden. Toen zei de grootmoeder: Niemand mag die kleurige draden losmaken; eerst als het kind groot geworden is in de wieg, zal het zelf de draden verbreken. - Wanneer dus de moeder het kind zoogde, stak ze de borst tusschen de draden aan het kind toe. Maar het kind had nog niet lang geleefd, toen ook de moeder overleed. $\mathrm{Nu}$ zorgde de Grootmoeder voor het meisje, en een tante kwam het zoogen.

Eindelijk was het kind zóó gegroeid, dat het door zijn grootte de draden deed doorknappen; toen viel het op den vloer en liep daarop voort. Haar overleden vader nu had een kamer in huis; de sleutel daarvan gaf de grootmoeder aan haar kleindochter, en toen sloot Pompoelion zichzelf in die kamer op, opdat niemand haar zou zien.

Eens was het vuur uitgegaan, en toen moest de grootmoeder Pompoelion wel naar het dorp sturen om vuur te vragen. Ze nam een doei-doei mosoni (soort mandje?) mee om het vuur in te doen. 
Maar de grootmoeder zeide haar: Als de wind van het land komt, houdt het vuur dan in de linkerhand, anders zullen de prauwen verbranden; als de wind van uit zee blaast, houd het vuur dan in de rechterhand, anders zullen de huizen verbranden. Toen de zeewind waaide, paste ze op; maar toen de landwind blies, gaf ze daarop geen acht, en daardoor verbrandden de prauwen, die op het land waren getrokken. De eigenaar nu van die prauwen was Ade Banggai, een broer van Sasonsina ( $\operatorname{sina}$ is ,zon”).

Toen Pompoelion thuisgekomen was, vertelde ze aan haar grootmoeder wat er was gebeurd: gouden en zilveren prauwen waren er verbrand. Ade Banggai nu deed overal navraag wie zijne prauwen had verbrand. In het dorp vertelde men hem, dat een heel mooi meisje om vuur was komen vragen, en dat zij het wel zou zijn geweest, die de prauwen in brand had gestoken. Daarom gelastte Ade Banggai twee van zijn slaven, Tapio poedoeng en Tapio bisa om dat mooie meisje te gaan zoeken, en haar te vragen tot Ade Banggai te komen.

De beide slaven zochten heel lang, en eindelijk vonden ze Pompoelion. Ze vroegen haar om naar Ade Banggai te gaan, maar Pompoelion wilde niet. Telkens vroegen de afgezanten het weer. Toen zei Pompoelion: Goed, gaat gij maar terug naar Ade Banggai, en zeg hem, dat ik zal komen.

Toen de beide mannen weggegaan waren, nam Pompoelion haar draagmand $(b a k i)$ en deed daarin een zwarten steen, dien ze van het graf van haar vader nam, en een witten steen, dien ze van het graf van haar moeder nam. Zoo ging ze dan op weg.

Toen ze halfweg gekomen was, wierp ze den zwarten steen naar het Westen, en den witten naar het Oosten, en ze zei daarbij: Wanneer mijn vader en mijne moeder werkelijk vorsten zijn, dan word ik opeens veranderd in een oude vrouw. En ze werd ook werkelijk opeens een oude vrouw.

Ade Banggai nu had alles in orde gemaakt voor de ontvangst van het mooie meisje. Maar in plaats van eene schoone maagd kwam er een oude vrouw. Ade Banggai was erg boos, en toen Pompoelion de trap vóór op wilde gaan, stootte hij haar terug; en toen ze de achtertrap wilde opgaan, stootte hij haar er af. Maar Sasonsina, Ade Banggai's broer, had medelijden met de oude vrouw. Hij liet een varkenshok onder de woning maken, en daar verbleef Pompoelion.

Ade Banggai zocht nu een andere vrouw, en hij vond er een, Daoede 
genaamd. Er zou een groot huwelijksfeest plaats hebben, waar allen heengingen. Ook Pompoelion vroeg er heen te mogen gaan, maar Ade Banggai zei : neen, blijf thuis. - Pompoelion bleef echter aandringen, en toen zei Ade Banggai: Goed, ga mee, maar als we zijn geland, moet je aan het strand blijven om op de prauwen te passen. Toen zeilde men weg tot men bij het dorp van Daoede aankwam. Daar werd een groot feest gevierd, maar Pompoelion was er niet bij, omdat ze op de prauwen paste.

Te midden van de feestvreugde zagen de menschen opeens een grooten gloed aan het zeestrand, en men riep: De prauwen staan in brand! Maar het was niet, dat de prauwen brandden, dat er zoo'n gloed was, maar Pompoelion had haar huid van de oude vrouw geopend, en van haar lichaam ging de glans uit.

Ade Banggai zond een slaaf uit naar het strand om te zien, wat er gebeurde. Maar toen hij daar kwam, was de glans weg, en Pompoelion was een oude vrouw. Toen de slaaf bij Ade Banggai terug was, zag men weer de glans, maar toen iemand ging kijken, was de gloed weer verdwenen. Dit gebeurde zoo eenige malen.

Op dien avond nu zou het haar van Daoede rondom het hoofd worden geschoren, zooals de gewoonte is bij meisjes die trouwen. Maar het zitvlak van Daoede was puntig, en daarom moest ze altijd tegen iets leunen, anders zou zij omvallen. Pompoelion nu had haar gedaante van jongmeisje weer aangenomen. $\mathrm{Ze}$ had de oogen dicht gedaan en gezegd: Als ik werkelijk een kind van vorsten ben, zullen er, als ik de oogen opendoe, 3 slaven en 3 slavinnen zijn, en vele roode paarden (adjahan kasoemba). - Toen ze de oogen opende, waren die allen er ook werkelijk. Zoo ging Pompoelion met al haar volgelingen naar het huis van Daoede. Men was daar erg verbaasd deze voorname gast te zien. Mij kende haar niet, maar toen zij vroeg om het haar in het rond om het hoofd van de bruid te mogen scheren, stond men haar dit toe. Ze ging in Daoede's kamer en schoor haar het haar om het hoofd in ' $t$ rond.

Sasonsina zei nu tot zijn broer Ade Banggai: Dat schoone meisje is de oude vrouw, die op de prauwen paste. - Toen Ade Banggai haar wilde opzoeken om navraag te doen, was Pompoelion met haar gevolg al heengegaan; en toen hij aan het strand kwam, was ze al weggezeild. Ade Banggai was echter zóó van haar bekoord, dat hij haar dadelijk volgde en Daoede in den steek liet.

Pompoelion kwam thuis, maar daar vond ze haar grootmoeder overleden, en alleen hare beenderen waren nog over. De parkiet, die D1. 86. 
Pompoelion had achtergelaten, leefde nog. De vogel sprak: Je grootmoeder is niet van honger gestorven, maar uit verlangen naar jou, omdat je niet terugkwam. - Toen nam Pompoelion de beenderen van haar grootmoeder, wies ze goed af, en wreef ze daarna met olie in. Ze zei een tooverspreuk over de beenderen en toen herleefde haar grootmoeder weer.

Ade Banggai nu was ook aan het huis van Pompoelion gekomen. Hij klopte aan en zeide: Hier is Ade Banggai, doe open. Maar Pompoelion antwoordde: Neen, ik doe je niet open, want je hebt mij weggejaagd. Toen trok Ade Banggai zich terug. Niet lang daarna klopte zijn broer Sasonsina aan, en zei : Hier is Sasonsina, doe open. Toen antwoorddde Pompoelion: Je hebt medelijden met mij gehad, en daarom doe ik je open. Toen ze de deur had geopend, sprong Ade Banggai te voorschijn, en drong het huis in. Hij wilde Pompoelion dwingen met hem te trouwen, maar de grootmoeder sprak: Als je met Pompoelion wilt trouwen, dan moet je ons huis overbrengen en naast het uwe zetten. - De grootmoeder zei dit, omdat ze dacht, dat Ade Banggai dit niet zou kunnen. Maar Ade Banggai zeide een tooverspreuk op, en toen stond het huis van Pompoelion opeens naast het zijne. Toen trouwde Ade Banggai met Pompoelion en hij keek niet meer naar Daoede om.

\section{RAADSELS.}

1. Dagi ko binatang aitoe pandai hondo na loemaap. Apa aitoe? Poniki.

$\mathrm{Er}$ is een beest dat heel knap is in vliegen. Wat is dat? De vleermuis.

2. Dagi ko anak booene, salata hampe tiba poetnjo, salata daka'mo madino monsoem boe mompoet. Apa aitoe? Oetan lingkong.

$\mathrm{Er}$ is een meisje dat geboren wordt met een haarwrong, maar als het groot geworden is, weet het niet meer een haarwrong te dragen. Wat is dat? Een varensoort, die als groente gegeten wordt. (Mal. sajoer pakoe).

Wanneer het jonge blad van deze varen te voorschijn komt, is dit geheel omgekruld als een haarwrong van een vrouw, maar ouder geworden strekt het blad zich.

3. Dagi ko samian na langkai, boetongnjo boeloeon, limanjo djoe- 
madjoeit, nooli noe mian ka oinoem. Apa aitoe? Konaoe ka doeangnjo.

$\mathrm{Er}$ is een oude man, wiens lichaam met haar bedekt is, uit zijn hand druppelt het, de menschen koopen dit en drinken het. Wat is dat? De arenplam en zijn vocht.

4. Dagi ko sambatoe na boea' noe kaoe; kaloe otoloek, adede; ababa. Apa aitoe? Doehian.

$\mathrm{Er}$ is een boomvrucht, als ze aangepakt (vastgehouden) wordt, zegt men: au, au daarna (zegt men) : ha, ha! Wat is dat?

De doerian-vrucht, welker stekels iemand eerst een kreet van smart ontlokken, maar als ze geopend wordt volgt een uitroep van verrukking.

5. Dagi ko anak aha aitoe, sata mohoempakmo palakala nohikoe na kapala. Apa aitoe? Salo ka mian anoe soemoehang.

Er zijn een aantal kinderen, als ze een rechtszaak (Mal. perkara) hebben gekregen, draaien ze het dorpshoofd den rug toe. Wat is dat? De vloer van het huis (die gedacht wordt als het dorpshoofd), en de menschen die er op zitten.

6. Dagi ko sa'angoe a kampoeng nahampate ti'anak; samian ihopoeannjo, metinontoeha samian. Apa aitoe? Pangasoe oeё.

Een heele kampong wordt met kinderen en al uitgemoord, een mensch maakt ze op, en er blijft maar één mensch over. Wat is dat? Het bamboe watervat (dat door één mensch wordt leeggegoten).

7. Dagi ko kaoe noenock, dagi soeboe ia mantan, sata sonsoeoen ia kodemo. Apa aitoe? Loloeng oe mian.

$\mathrm{Er}$ is een waringin-boom, 's morgens is hij hoog, en 's middags is hij laag. Wat is dat? De schaduw van den mensch.

8. Dagi ko sapoeoen na kaoe, hoonnjo soemo badjak, boea'njo soema soepa. Apa aitoe? Nanasi.

$\mathrm{Er}$ is een boom, zijn bladeren zijn als hakmessen, zijn vrucht is als een rijstmaat. Wat is dat? De ananas.

9. Dagi ko samian na mian mipajoeng, misa radja, misonoekoe, misa ikan. Apa aitoe? Nanasi moele'.

$\mathrm{Er}$ is een mensch die een zonnescherm draagt, en toch geen vorst is, die schubben heeft en toch geen visch is. Wat is dat? Weer een ananas (hier is echter speciaal de vrucht bedoeld).

10. Anoe bangka' mohombi tagelong, inmihinjo mandjoo njewekan. Apa aitoe? Doeang ka malangoe.

De opgezwollene slaat de kromme en later heeft hij veel praats. 
Wat is dat? Palmwijn en dronken zijn (met een stuk hout wordt de omgebogen vruchttros beklopt, d.i. het bewerken van den arenboom, en als men dronken is geworden van het vocht, heeft men veel praats).

11. Gohoeng oemonjo, siok madjama. Apa aitoe? Anoe mongoedja: pae aloe tiba howas.

De donder weerklinkt en de kuikens zijn blij. Wat is dat? Degeen die rijst stampt, de stamper en de ontbolsterde rijst (de donder is het geluid van het stampen, en de rijstkorrels openbaren hun blijdschap door op te springen).

12. Dagi ko nioe sambatoe, kolong sakolong, madi ko isinjo. Poso'njo: papo.

$\mathrm{Er}$ is een kokosnoot, snijd er een stuk af, en er is geen vleesch in. Beteekenis: De kalkbus, waarvan het deksel het afgesneden stuk beteekent.

13. Dagi ko sopoet aitoe, kaloe opepa, timbali ale santake. Poso'njo: lolong oe sagin. (Zie ook No. 43).

$\mathrm{Er}$ is een blaasroer, als men het uitspreidt, wordt het een rijstveld. Beteekenis: een jong pisangblad, dat opgerold uitkomt, als een blaasroer.

14. Dagi ko anak aitoe toemoe i oeё, mate i oeë. Poso'njo: ladang.

$\mathrm{Er}$ is een kind dat in het water leeft en in het water sterft. Beteekenis: de sagoboom.

15. Dagi ko sangkaoe na kaoe, boekoe na boea'njo, kilitnjo popa. oe ladang, panganjo oerve. Apa aitoe? Tibok.

$\mathrm{Er}$ is een boom, beenderen heeft hij tot vrucht, bladscheede van den sagoboom tot schors, en rotan tot takken. Wat is dat? De sirihdoos der mannen (die van hout is gemaakt met een deksel van sagobladscheede, en een band van rotan er omheen, die doos en deksel bijeenhoudt).

16. Dagi ko anak aitoe, salata hampe tiba laigannjo. Apa aitoe? Bojoekoe.

Er is een kind, dat met zijn huis geboren wordt. Wat is dat? De slak.

17. Dagi ko sa'angoe na kampoeng, pakiannjo aitoe maoe booene moane soepoe misongko. Apa aitoe в Kaoe poeloli.

$\mathrm{Er}$ is een kampong waar zoowel vrouwen als mannen altijd een 
hoed dragen. Wat is dat? De poeloli-boom (wiens vruchten veel van eikels hebben, de vruchtdrager stelt dan de hoed voor).

Of : izvi-iwi a boea'njo tisongko. D.i. Alle vruchten hebben elk een hoed.

18. Dagi ko sa'angoe na laigan iboiboina, isi noe laigannjo madi liwat aha olima, soepoe olima isinjo. Apa aitoe? Sapatoc ka boea' noe tengke.

$\mathrm{Er}$ is een huis van Grootmoeder; de bewoners van dat huis komen nooit de vijf te boven; altijd zijn er vijf bewoners. Wat is dat? De schoen met de vijf daarin stekende teenen van den voet.

19. Dagi ko anat aitoe mongkan $i$ doenia hojot $i$ bobotoengo. Apa aitoe? Boengkang.

$\mathrm{Er}$ is een kind, dat op de aarde eet, en in de aarde slaapt. Wat is dat? De kreeft.

20. Dagi ko sangkaoe na ohii oe laigan, ohii satotonjo, bolo'njo olalilalin. Apa aitoe? Sising ka kangkam.

$\mathrm{Er}$ is een paal van een huis, de paal blijft maar staan, maar het gat er van verwisselt telkens. Wat is dat? De ring (het gat) aan den vinger (de paal).

Of : Dagi ko sa'angoe abolo olalin. D.i. Er is een gat dat verhuisd (verplaatst) wordt.

21. Dagi ko sa'angoe kampoeng aitoe soepoe ko oelo. Apa aitoe? Tindoeng.

Er is een dorp, dat vol pezen zit. Wat is dat? De regenmat (die uit aaneengeregen pandanbladeren bestaat en daardoor veel strepen (als pezen) vertoont).

22. Oeampoeloe ka olima na takean noe dopi, pakana sama dala na anoe hojot aitoe. Apa aitoe? Doson ka damak.

25 stuks planken, maar duizend die er in slapen. Wat is dat? De doson met damar (een mand die gemaakt is van een aantal repen bamboe, die met rotan aan elkaar verbonden zijn; de ,duizend” zijn de stukjes damarhars, die in zulk een mand op den rug vervoerd worden).

23. Dagi anak na ia misaloean, salata daka'mo na ia milanggomo. Poso'njo: balo.

$\mathrm{Er}$ is een kind, dat een broek (soms zegt men: baadje) aan heeft, terwijl het als het groot is, naakt is. Oplossing: bamboe (met de broek of het baadje wordt de scheede bedoeld, waarin de bamboe- 
spruit is gewikkeld, en waaruit zich later de naakte bamboestengel verheft).

24. Dagi ko ale iboiboina kondjo-kondjoo pakana banit ala-alamo santimpa. Apa aitoe? Oeba. (Zie No. 86).

$\mathrm{Er}$ is een rijstveld van grootmoeder met heel veel (rijst), maar als (die rijst) gesneden wordt, haalt men er een bos van. Wat is dat? Het hoofdhaar (dat veel lijkt, maar afgesneden slechts een klein bundeltje is).

25. Dagi ko iboiboina soeha-soehang i laigannjo, pakana limanjo mompahakazera toemondo kodjo-kodjoon $i$ tanonjo. Poso'njo: montoelis socrat.

Daar is grootmoeder, die maar in huis zit, maar haar hand reikt zij aan vele vorsten in hun (eigen) land. Oplossing: brieven schrijven (terwijl de schrijver thuis blijft, gaat de brief die de hand geschreven heeft, naar iemand in een ver land).

26. Dagi ko tomoendo mamba mahantabas, salata konao natabas jo ia dagi mae minsoelsoele, salata madimo, jo ia madimo mae minsoesoele. Poso'njo: hihis. (Zie ook No. 74).

$\mathrm{Er}$ is een vorst die gaat jagen; als hij iets raakt, snijdt hij er in, en dan keert hij weer terug; als hij niet (treft), dan keert hij ook niet meer terug. Oplossing: de pijl uit het blaasroer (als deze het wild treft en doodt, krijgt de jager met het wild de pijl terug; treft de pijl niet, dan is ze verloren).

27. Dagi ko anak iboiboina dagi ise na aha dagi moimboa, salata toea'njomo na aha mahampoengkoenmo. Poso'njo: manoek.

De kinderen van grootmoeder zijn zoolang ze klein zijn, familie van elkaar (in den zin van: aan elkaar gehecht), maar als ze groot zijn, vechten ze met elkaar. Oplossing: hoenders.

28. Dagi ko patoe'on iboiboina pengkotnjo na akaong mae lobolobong $i$ ambai, pakana oebaknjo na aita mae mongkan i boengkoetnjo. Apa aitoe? Lampoe tiba soemboenjo.

Een huisdier van grootmoeder heeft zijn staart naar beneden in de zee afhangen, terwijl zijn hoofd naar boven steekt en op den berg eet. Wat is dat? De lamp en de lampekous.

29. Dagi kutampoea iboiboina odoempoe $i$ ampinjo. Apa aitoe? Soesoe noe booene.

De aardhoop (die b.v. om jonge sago- en kokosboomen wordt opgeworpen om ze krachtiger te doen groeien) wordt op de helling 
er van (in het midden tusschen voet en top) opgehoogd. Wat is dat? De vrouwenborst (die in het midden opzwelt).

30. Dagi ko patoe'on noe tomoendo nopinsoele na Banggai. Poso'njo: mata.

$\mathrm{Er}$ is een huisdier van den vorst, dat van Banggai is teruggekeerd. Beteekenis : het oog (dat Banggai bereikt - kan zien).

31. Dagi ko mian noe iboiboina oegat saatoe na madala, pakana nopatei noe anak samian. Poso'njo: kalapini tiba pae.

Er zijn misschien 100 of 1000 menschen van grootmoeder, maar die worden gedood door slechts één kind. Oplossing: het rijstmesje en de rijst (het rijstmesje dat duizenden aren afsnijdt).

32. Polipik iboiboina mailoloi pee i tano toka-toka i langit. Poso'njo: balo.

De vleugels van grootmoeder vervolgen elkaar van den grond tot aan den hemel. Oplossing: de bamboe (de scheede, die zich aan elke bamboegeleding bevindt, wordt vergeleken met een vleugel).

33. Dagi ko ponoha iboiboina, antoknjo na madi oala, pakana boekoenio na oala. Apa aitoe? Oewe.

$\mathrm{Er}$ is vleeschspijs van grootmoeder, waarvan het vleesch niet genomen wordt, maar waarvan de beenderen genomen worden. Wat is dat? Rotan (waarvan het merg weggeworpen en de bast gebruikt wordt).

34. Dagi ko aha olima na motoetooes, salata ahamo opat na motooetoes mate, doedoen kooima'njo madimo makeke. Posónjo: lima tiba kangkam.

Er zijn vijf gebroeders, wanneer 4 van die broeders dood zijn, is de vijfde niet krachtig meer. Oplossing : de hand met de vingers (wanneer de 4 vingers gewond zijn, kan de duim alleen niets doen).

35. Dagi ko samian pakana tengkenjo totoloe. Poso'njo: mian langka-langkai.

$\mathrm{Er}$ is een mensch, maar hij heeft drie beenen. Oplossing : een oud mensch (die met een stok tot steun moet loopen).

36. Mintao salala, moliba salala. Poso'njo: Toete.

Naar beneden gaande zegt het salala; naar boven gaande zegt het salala. Oplossing: de kat (die de trap afgaande of opgaande altijd miauw zegt).

37. Iboiboina, boetongnjo lagasoeng, matanjo dagi ko djila-dj̣ila, Apa aitoe? Poso'njo: kamansi. 
Van grootmoeder is het lichaam vergaan, maar haar oogen schitteren nog. Oplossing: de vrucht van den broodboom, Artocarpus communis (waarvan het vleesch spoedig zacht is als dit gekookt wordt, maar de pitten blijven glanzen).

38. Moliba ka mobanatoeoe, mototiliban na songko. Poso'njo: poeloli.

Of ze naar boven gaan of naar beneden vallen, ze hebben alle een hoed op. Oplossing: de vruchten van de poeloli, of Indische eikel, Quercus Celebica (de vruchten van dezen boom lijken op de eikels, de vruchthouder wordt hier de hoed genoemd).

39. Maoe tomoendo nosoehang noe anak ise-ise aia $i$ siakan. Of: Dagi ko samian maoe tomoendo ala nolangga-langgai. Apa aitoe? Lalo.

Zelfs bij vorsten zitten de kleine kinderen ervan hen op het voorhoofd. Of : Er is iemand, die al is het een vorst, over hem heen durft loopen. Wat is dat? De vlieg.

40. Dagi ko adjahan $i$ tonga oe padang, madi ia mongkan hempoet, panjo mongkan tano. Poso'njo: koetoe.

Er zijn paarden in het veld; ze eten geen gras, maar ze eten aarde. Oplossing : luizen (die op het hoofdvuil teren).

41. Dagi ko sa'angoe anak ia mampoboa-boa intam. Apa aitoe? Koehap.

$\mathrm{Er}$ is een kind dat voortdurend een edelsteen met zich draagt. Wat is dat? de vuurvlieg.

42. Kolonga boengkoetnjo sa'angoe, mohoempak oeё. Apa aitoe? Nioe.

Als men een berg doorhakt, vindt men water. Wat is dat? Een kokosnoot.

43. Oposok lambangan sa'angoe, timbali ale santake. Apa aitoe? Lolong noe sagin. (Zie ook No. 13).

Als men een boeloe toewi (soort dunne bamboe) verbreekt, wordt het een akker. Wat is dat? Het jonge blad van de pisang (dat opgerold groeit, maar dat men openlegt om er rijst in te verpakken).

44. Dagi ko sa'angoe balase oe pae, paenjo madi ooedjang, panja balasenjo na oedjang. Apa aitoe? Lobian.

$\mathrm{Er}$ is een (van palmblad gevlochten), zak met rijst; de rijst wordt niet gekookt, maar de zak wordt gekookt. Wat is dat? De laboe, Lagenaria vulgaris (waarvan de pitten worden weggegooid, en het omhulsel gekookt wordt). 
45. Dagi ko sambatoe na ikan, madi lompo $i$ antoknjo, panjo molompo i bohibitnjo. Apa aitoe? Atop.

$\mathrm{Er}$ is een visch die niet vet is in het vleesch, maar vet aan de borstzijde. Wat is dat? Het dak (bohibit is de rand van een baadje, ook wel het oplegsel dat zich vaak aan den rand er van bevindt; de "rand" van de visch is hier het scherpe borststuk; de zin is: wanneer het geregend heeft, is de nok van het dak al droog, wanneer het aan de dakranden nog druppelt). (Vergelijkt No. 94).

46. Nioe noe Banggai mompahanjawe nioe $i$ Talinate. Apa aitoe? Bangkoelang.

De kokosboom van Banggai raakt met de bladeren aan die van den kokosboom van Ternate. Wat is dat? De wenkbrauwen.

47. Panimboeloeon ina aitoe, nodjoloi noe oelo moitom. Apa aitoe? Kakoja of tindoeng.

Over gindschen heuvelrug kruipt een zwarte slang. Wat is dat? Een regenmatje (dit bestaat uit repen pandanusblad, die aan elkaar geregen, en in het midden omgevouwen worden: over de vouw wordt een reep donker katoen genaaid om aan dit voorwerp stevigheid te geven).

48. Inda oko, inda oko (of inta oko, inta akoe). Apa aitoe? Molangkasakon.

Vooruit jij, vooruit jij. Wat is dat? Het voortstappen van de beenen. (Zie No. 54).

49. Siloi pakot, siloi kapot. Apa aitoe? Bihing.

Omkijken, verdwenen, omkijken, verdwenen. Wat is dat? Het oor (als men er naar wil kijken, is het door het wenden van het hoofd tevens verdwenen).

50. Kolontoeat, kolontoeat. Of : Dagi ko sa'angoe mian, basoengnjo kolontoeat. Apa aitoe? Soeoeng.

Onderste boven, onderste boven. Of: $\mathrm{Er}$ is een mensch die zijn draagmand onderste boven draagt. Wat is dat? de neus (die met de opening naar beneden is gekeerd.

51. Lintoboeng ina aitoe tinondok oe besak. Apa aitoe? Nganga ka bese. (Zie ook No. 79):

Die poel daarginds is door een ijzeren heining omringd. Wat is dat? De mondholte met de tanden.

52. Popos ina aitoe oalin notoka na togon. Apa aitoe? Mata. 
De pinangnoot daarginds wordt weggeworpen en komt op het eiland. Wat is dat? Het oog (dat ver reikt).

53. Ponoha sampado ina aitoe, maoe mboele sihoeoe ma mian, madi opokokan. Of : Ponoha iboiboina madi ko kamingkotanjo. Apa aitoe? Boitan.

Ginds stuk vleesch, al komen ook alle menschen er zich om verzamelen (om er van te eten), het wordt niet opgegeten. Of : De vleeschspijs van grootmoeder raakt nooit op (ten einde). Wat is dat? Een slijpsteen.

54. Pasi-pasi doongkocng, pasi-pasi dangkang. Apa aitoe? molangkàsakon.

Gebogen vooruit, met de beenen van mekaar vooruit. Wat is dat? Het voortstappen van de beenen. (Zie ook Nò. 48).

55. Dagi ko sa'angoe mian, makakio i salikoe, loebat i salikoe. Apa na aitoe? Paka'oet.

$\mathrm{Er}$ is iemand, die in het eene diepe deel van de rivier onderduikt, en op een andere diepe plek te voorschijn komt. Wat is dat? De naald (die op en neer steekt).

56. Dagi ko sa'angoe goela iboiboina, mamba samian molodjok. Apa na aitoe? Papo tilon.

Daar is de suiker van grootmoeder, ieder steekt er den vinger in. Wat is dat? Het kalkpotje (waarin ieder bij het sirihpruimen den vinger steekt om er zich van te bedienen).

57. Dagi ko sa'angoe na mian mombaoebaoeon, notoenoe bengga, madi nodait, notoenoedje na soligege, oe dait dje. Apa na aitoe? Soeloe.

$\mathrm{Er}$ is iemand, die een feest maakt, hij roostert een buffel, en het is niet voldoende; hij roostert een soligege (naam van een kleinen vogel), en dan is het (vleesch) voldoende (voor al de gasten). Wat is dat? De lamp (de groote lompe harsfakkel, die weinig licht geeft, is hier de buffel; tegenover de kleine petroleumlamp, die haar licht overal heen verspreidt; toenoe is zoowel roosteren als aansteken).

58. Dagi ko sa'angoe binatang, țondjolonjo salamba-lamba; atenjo mololo; binatang aitoe sadjodjongnjo. Apa na aitoe? Laigan ka miannjo. Of: Adjaham i kele boetongnjo soepoe loekoet-loekoet ola atenjo na mololo.

$\mathrm{Er}$ is een beest, het strekt zich in één richting uit; zijn lever (of zijn innerlijk) gaat er op uit; maar het beest zelf blijft op zijn plaats, 
Wat is dat? Een huis en de bewoners (het huis blijft op zijn plaats en de bewoners gaan overal heen). Of: Een paard waarvan de rug op zijn plaats blijft, maar waarvan de lever er op uitgaat (zich voortbeweegt).

59. Dagi ko kaliding mian aitoe, nooena i sambihanjo. Apa aitoe? Bihing.

Iemand heeft een mandje, dat hij aan den buitenkant (van zijn huis) bewaart. Wat is dat? De oorschelp.

60. Dagi ko docangan iboiboina sake'njo ola Poea adji. Apa aitoe? Solo.

Er is een prauw van grootmoeder, waarvan de lading uit louter Mekkagangers bestaat: Wat is dat? Een doos lucifers.

61. Lintoboeng iboiboina madi ko matanjo. Apa aitoe? Nioe.

De put van grootmoeder heeft geen wel. Wat is dat? Een kokosnoot.

62. Dagi ko sa'angoe anak iboiboina, ola minsan na ia mongkan. Poso'njo: Tangonan.

Grootmoeder heeft een kind dat slechts eenmaal heeft gegeten. Oplossing het hoofdkussen (dat slechts eenmaal met kapok wordt opgevuld).

63. Mandjoo hondo na mian mindii $i$ oeё, panjo madi mohiboe; minsandje mian anoe magesoek, atinadje ka mohiboe. Apa aitoe? Mongoendjang. Of: Maka kiop a tomoendo maisa mohiboe, maka kiop dja na botoean, mohiboe dje.

Zeer veel menschen baden zich in het water, en het wordt niet troebel; als slechts éénmaal een mager mensch (er in baadt), wordt het troebel. Wat is dat? Rijstkoken (wanneer de rijst te vuur wordt gezet, is het water nog niet troebel ,maar als de magere steel van de pollepel er in roert, wordt het troebel). Of als de radja onderduikt, wordt het (water) niet troebel, eerst als zijn slaaf onderduikt, wordt het troebel.

64. Dagi ko aitoe samian, sina malom ia soepoe loemadjang. Apa aitoe? Oë̈.

Er is iemand, die dag en nacht maar steeds loopt. Wat is dat? Het water (in de rivier).

65. Dagi ko sa'angoe na kapan, sake'njo ola gamben. Poso'njo: Tede noe adjahan. 
Er is een schip, waarvan de lading slechts gambir is. Oplossing: Paardefaeces.

66. Dagi ko samian na langka-langkai nopahampateakon noe anoe $i$ mada-madalannjo, madi mate. Apa na aitoe? Koehon.

$\mathrm{Er}$ is een oud man, die met duizenden vecht, en niet dood gaat (of : een oud man verslaat duizenden, maar gaat zelf niet dood). Wat is dat? De kookpot (waarin ontelbare rijstkorrels gaar - dood - gekookt worden).

67. Dagi ko aha popitoe djinodjong $i$ oeno noe sa'angoe a laigan, toto samian koposisalipinjo. Apa aitoe? Boea noe doehian.

Ze zijn met hun zevenen, die maar binnen in huis blijven, ieder in zijn eigen kamertje. Wat is dat? De doerianvrucht.

68. Dagi ko aha totoloe ninsop $i$ oeno noe salipi; inihi nosabat me samian i hoempismo noe baso. Apa aitoe? Hampa, popos ka tilon.

Met hun drieën gaan ze in een kamer; later komt er nog maar één uit, geheel nat van bloed. Wat is dat? Sirih, pinang en kalk (die tezamen gekauwd worden, en het roode speeksel voortbrengen, dat wordt uitgespuwd).

69. Anak iboiboina olaga na okoea, lamba-lamba basoon. Poso'njo: momangan.

Het kind van grootmoeder wordt aangeroepen, en brengt een bezoek, en dadelijk is het bebloed. Oplossing : sirih kauwen (aan een bezoeker wordt sirih-pinang voorgezet, en deze maakt het roode sirihspeeksel).

70. Dagi ko ikan sampadot; ikan aitoe okan, madi komingkotannjo. Apa aitoe? Djila.

$\mathrm{Er}$ is een stuk visch; die visch wordt gegeten, maar ze raakt niet op. Wat is dat? De tong.

71. Otoa' timbali, okanjang madi timbali. Apa aitoe? Loloeng $i$ mongkitaan.

Men kan het zien, maar men kan het niet grijpen. Wat is dat? Het spiegelbeeld (mongkitaan is ook voorbeeld, model, iets dat men afkijkt).

72. Boengkoetnjo mobehe loebat na njawa. Apa aitoe? Galaoe' mimoso.

De berg wordt gespleten en er komt een ziel uit. Wat is dat? Een ei, dat openbreekt (en waaruit een kuiken komt). 
73. Oë̈ $i$ kele oasocoe $i$ pohintongaan noe langit. Apa aitoe? Doeang.

Het water van grootmoeder wordt midden in het luchtruim opgeschept. Wat is dat? Palmwijn (die van den boom afgetapt wordt).

74. Dagi ko samian namba mombebas; de mohoempak mae baoe dagi mae ntinsoesoeloe; de madi mae ia mohoempak mambamo na ia i koehak. Apa aitoe? Hihis.

Iemand gaat uit jagen; als hij een varken heeft gekregen, keert hij terug; als hij niets heeft gevonden, gaat hij het bosch in. Wat is dat? De pijl van het blaasroer. (Vergelijk No. 26).

75. Anak i kele mosisali-salipi. Apa aitoe? Oeani.

De kinderen van grootmoeder hebben elk voor zich een kamertje. Wat is dat? Bijen (in het bijennest).

76. Takoehak sakakaannjo, poete'an salalaapnjo. Apa aitoe? Bobolo ka lobano.

De donkergroene boschduif is maar aan het eten; de witte boschduiven zijn maar aan het vliegen. Wat is dat? De bijl en de spaanders (de bijl die voortdurend in het hout hakt en er de spaanders van af laat vliegen).

77. Ikan $i$ kele otoloek $i$ atenjo. Apa aitoe? Kanta.

De visch van grootmoeder wordt in de lever gegrepen. Wat is dat? 't Schild (waarvan het handvat zich in het midden bevindt).

78. Dagi ko samian mindako mintoea mohoempak ocalinnjo. Apa aitoe? Soebat.

$\mathrm{Er}$ is iemand die bergen bestijgt en bergen afdaalt en vindt zijn vijand. Wat is dat? De haarkam.

79. Boeboeng i kele tinondok oe salaka. Apa aitoe? Nganga.

De put van grootmoeder heeft een zilveren heining. Wat is dat? De mondholte (omrìngd door de rij tanden). (Zie ook No. 51).

80. Polintoep a gohoeng, tangoekap $a^{\bullet}$ doenia. Apa aitoe? Peti.

Het ratelen van den donder en de aarde opent zich. Wat is dat? Een kleerenkist (deze kisten zijn voorzien van sloten met bellen er aan, die met het omdraaien van den sleutel rinkelen, waarna men de kist kan openen).

81. Dagi ko sandoempoek a batoe, kadjangan noe ikan sa'angoe. Apa aitoe? Djila.

$\mathrm{Er}$ is een hoop steenen, waar een visch ingaat. Wat is dat? De tong (die tusschen de rij tanden inzit). 
82. Minsop mae $i$ poeoes noe tano, minsop poepoe-poepoes. Apa aitoe? Adat.

Het komt naar binnen bij het einde der aarde, en gaat er tot aan het einde in. Wat is dat? De adat (die ten allen tijde, geheel en al, gevolgd moet worden, van de vroegste tijden af).

83. Koesapahakon na oebakkoe timbali apoe. Apa aitoe? Solo.

Ik sla met mijn hoofd, en er ontstaat (komt) vuur. Wat is dat? Lucifers.

84. Mongala sanaang, mongkan tolohiis. Apa aitoe? Mase noe malisa.

Men neemt het met genoegen, als men het eet, voelt men zich onaangenaam. Wat is dat? De scherpte van Spaansche peper.

85. Tano'koe tano'njo, sanggonjo, sanggokoe. Apa aitoe? Oeani, of liatong.

Mijn land is zijn land, zijn naam is mijn naam. Wat is dat? De bij, of de brandnetel (Dit is eigenlijk geen raadsel; wanneer men door bijen gestoken wordt of met brandnetel in aanraking gekomen is, legt men het gestoken lichaamsdeel tegen een boom, en zegt bovenstaande woorden, opdat de pijn zal ophouden; met die woorden draagt men de pijn op den boom over).

86. Ale $i$ kele santake, pinadak a paenjo ola santimpa'. Apa aitoe? Hambahan oebak.

Grootmoeder heeft een rijstveld, maar als de rijst er van geoogst is, is het slechts één bos. Wat is dat? Het hoofdhaar (padak en banit beteekenen beide rijstsnijden, het eerste is dagelijksche, het tweede oogsttaal).

87. Kilit $i$ kele madi kohison, ola $i$ oeno noe kilitnjo kohinson. Apa aitoe? Pehing.

De huid van grootmoeder heeft geen schubziekte, alleen binnen in de huid is schubziekte. Wat is dat? De bamboe betoeng (die van buiten glad is, maar waarvan het zachte binnengedeelte het voorkomen heeft van een geschubde huid).

88. Dagi ko samian loemadjang mae $i$ poeoes oe kampoeng, ola toka $i$ poeoes oe kampoeng matemo. Apa aitoe? Mompawot atop.

Er is iemand die naar het einde van de kampong loopt, maar als hij aan het eind van de kampong gekomen is, is hij dood. Wat is dat? Dakbedekking van sagoblad naaien (langs een lat van het eene einde tot het andere, waarna de ,draad” wordt afgehecht). 
89. Dagi ko samian ia mongkaeng boa-boa na laigannjo, ie male boaboa na laigannjo. Apa aitoe? Oemang.

$\mathrm{Er}$ is iemand die onder het werken zijn huis bij zich draagt, en als hij slaapt draagt hij zijn huis met zich. Wat is dat? De slak.

90. Mintandoek i tengke, mingkonoekoe i oebak. Apa aitoe? Tadi oe manoek ka toengkoesnjo.

Aan den voet draagt hij een hoorn, aan den kop draagt hij een nagel. Wat is dat? De sporen en de snavel van een haan.

91. Aha totoloe a mahandoepoe da samian na motojo'. Apa aitoe? Potinding.

Met hun drieën slaan ze tegen mekaar en een van hen verbrandt. Wat is dat? De vuurslag (bestaande uit steen, staal en tonder).

92. Otoa balo moitom, okoelisik balo mokini. Ape aitoe? Binde.

Gezien is het een zwarte bamboe, geopend is het een gele bamboe. Wat is dat? De maisvrucht (als deze oud is, worden de dekbladeren zwart, voor een deel door den rook van het haardvuur, waarin ze hangen om ze te bewaren).

93. Oemapos na djonga, mohata na boengkoetnjo. Apa aitoe? Sindoe ka pae $i$ lean.

Als een hert den krijgsdans uitvoert, wordt de berg gelijk (geslecht). Wat is dat? Een lepel en rijst op het bord (de lepel die al scheppende den berg rijst op het bord doet verdwijnen).

94. Ikan i kele molompo i bohibitnjo. Apa aitoe? Pohodas.

De visch van grootmoeder is vet aan den rand (de borst). Wat is dat? De dakrand. (Vergelijk No. 45).

95. Oealoe na mian momboenoe, ohoea sakoesii, madi osoemboe na mian oeboenoe. Apa aitoe? Pohapa lima.

Acht menschen dooden (begaan een moord), twee zijn getuigen, de man die gedood wordt is onbekend. Wat is dat? De beide handen tegen eens anders hand slaan (als groet bij de Mohammedanen aan het strand; de duimen staan daarbij overeind als getuigen). 


\section{BIJLAGE.}

\section{Bevolkingscijfers der To Loinang.}

Door de vriendelijke hulp van den fd. Controleur te Loewoek, Kapitein J. F. H. L. Goslings, ontving ik een opgaaf van het zielental der inwoners van de dorpen in de door To Loinang bewoonde dorpen van de distrikten Mendono en Tangkian. Zulk een statistiek wordt elk jaar opgemaakt, bij gelegenheid, dat de aanslag in de belasting plaats heeft. Aangezien met verschillende omstandigheden geen rekening kan worden gehouden, zijn deze opgaven niet in alle opzichten betrouwbaar. In de kustplaatsen, woont een zeer gemengde bevolking, met een klein percentage aan Loinangs; in enkele van die plaatsen wonen uitsluitend vreemdelingen. Overbodig is op te merken, dat de inwoners van de dorpen, die buiten het op de kaart aangegeven woongebied der To Loinang wonen, niet meer tot dezen stam mogen worden gerekend te behooren. De spelling van de namen der plaatsen heb ik gelaten zooals deze in de kohieren der belasting zijn inge-schreven. De opgaven gaan over drie jaren: 1920, 1924 en 1928, zoodat eenige vergelijking mogelijk is.

Bevolkingscijfers in het Distrikt Mendano:

\begin{tabular}{|c|c|c|c|c|c|c|c|c|c|c|}
\hline Dorpen. & & & & & & & & 1920 & 1924 & 1928 \\
\hline Lambangan. . & & $\cdot$ & $\cdot$ & . & . & . & . & 663 & 544 & 315 \\
\hline Pisou. . . . & 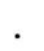 & . & 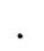 & . & . & & & 164 & 181 & 249 \\
\hline Basaboenga . . & 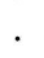 & . & . & . & . & & & 450 & 195 & 105 \\
\hline Pagimana . . & . & . & . & . & . & 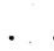 & & 336 & 416 & 6 \\
\hline Lengkoean. . & . & . & . & . & 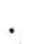 & . & & 107 & 158 & 130 \\
\hline Tongkonoenoe & . & . & 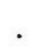 & 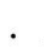 & & & & 317 & 224 & \\
\hline Sinampangnjo. & . & & & & & & & 56 & 74 & \\
\hline Hohoedangan . & . & . & . & . & $\cdot$ & . & & 51 & 64 & \\
\hline Badjo Pagimana & & . & . & . & . & . & . & 442 & 538 & \\
\hline Pokowa Pagimar & & . & . & . & . & . & . & 140 & 131 & \\
\hline Tondok . . . & & . & . & . & 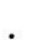 & . & & 61 & 71 & \\
\hline Sepa . . & . & . & • & • & . & . & . & 91 & 98 & 127 \\
\hline Talojon . . & . & . & . & - & . & . & - & 114 & 108 & \\
\hline Dewe daka . & . & & . & . & . & . & . & 88 & 105 & \\
\hline Tintingan . & . & & & . & . & . & . & 195 & 218 & 16 \\
\hline Onsolikoe . . & . & & & & & $\cdot$ & & 93 & 104 & 16 \\
\hline
\end{tabular}


$\begin{array}{llll}\text { Dorpen. } & 1920 & 1924 & 1928\end{array}$

Hoehak . . . . . . . . . . . . 6307146

Mahaap . . . . . . . . . . . $\quad 8908$ (08 48

Pooh . . . . . . . . . . . $390 \quad 466 \quad 299$

Badjo Poat Selatan . . . . . . $305 \quad 143 \quad 192$

Gamoeo Poat Selatan . . . . . $105 \quad 115 \quad 140$

Tampe Poat Oetara . . . . . . . . . $\quad 200 \quad 92 \quad 104$

Baleigondi Poat Oetara . . . . . $\quad \begin{array}{llll}102 & 114 & 138\end{array}$

Boealimo . . . . . . . . . $354 \quad 416 \quad 532$

Longkoga . . . . . . . . . $264 \quad 321484$

Malik . . . . . . . . . . . $309 \quad 320 \quad 287$

Majajap. . . . . . . . . . $119 \quad 171 \quad 376$

Salipi . . . . . . . . . . . $\quad 8201050$

Binsil. . . . . . . . . . . . . $127 \quad \begin{array}{lll}143 & 153\end{array}$

Nipa Sampaka . . . . . . . . $\begin{array}{llll}131 & 143 & 153\end{array}$

Sioena . . . . . . . . . . . 2192450

Lingketeng. . . . . . . . . $\quad \begin{array}{llll}314 & 247 & 103\end{array}$

Indang . . . . . . . . . . . . $\quad 50 \quad 6159$

Bahibgin. . . . . . . . . . . . $\begin{array}{rrrr}83 & 87 & 114\end{array}$

Pinapoean . . . . . . . . . . $308 \quad 159233$

Tamboenan. . . . . . . . . . . $114 \quad 146 \quad 174$

Balowa . . . . . . . . . . $136 \quad 150 \quad 246$

Boelakan . . . . . . . . . . $\quad 8000$

Salingan. . . . . . . . . . . . $\quad 61 \quad 8101$

Totaal . . . . . . . . $7373 \quad 7224 \quad 8353$

Bevolkingscijfers in het Distrikt Tangkian:

$\begin{array}{llll}\text { Dorpen. } & 1920 & 1924 & 1928\end{array}$

Boenta . . . . . . . . . . . $607 \quad 714 \quad 679$

Bohotokong. . . . . . . . . . $297 \quad 404 \quad 534$

Pongiang . . .. . . . . . . . . $300 \quad 171 \quad 196$

Tobelombang . . . . . . . . . 440460405

Bella-Petak. . . . . . . . . . $\begin{array}{llll}323 & 282 & 227\end{array}$

Temeang . . . . . . . . . . . 280267

Balaang . . . . . . . . . . 1090133156

Batoeitam . . . . . . . . . . $\quad 36 \quad 46 \quad 105$

Bangketa . . . . . . . . . . $\quad 211 \quad 153 \quad 194$

Taema . . . . . . . . . . . . $303 \quad 362 \quad 380$

D1. 86. 


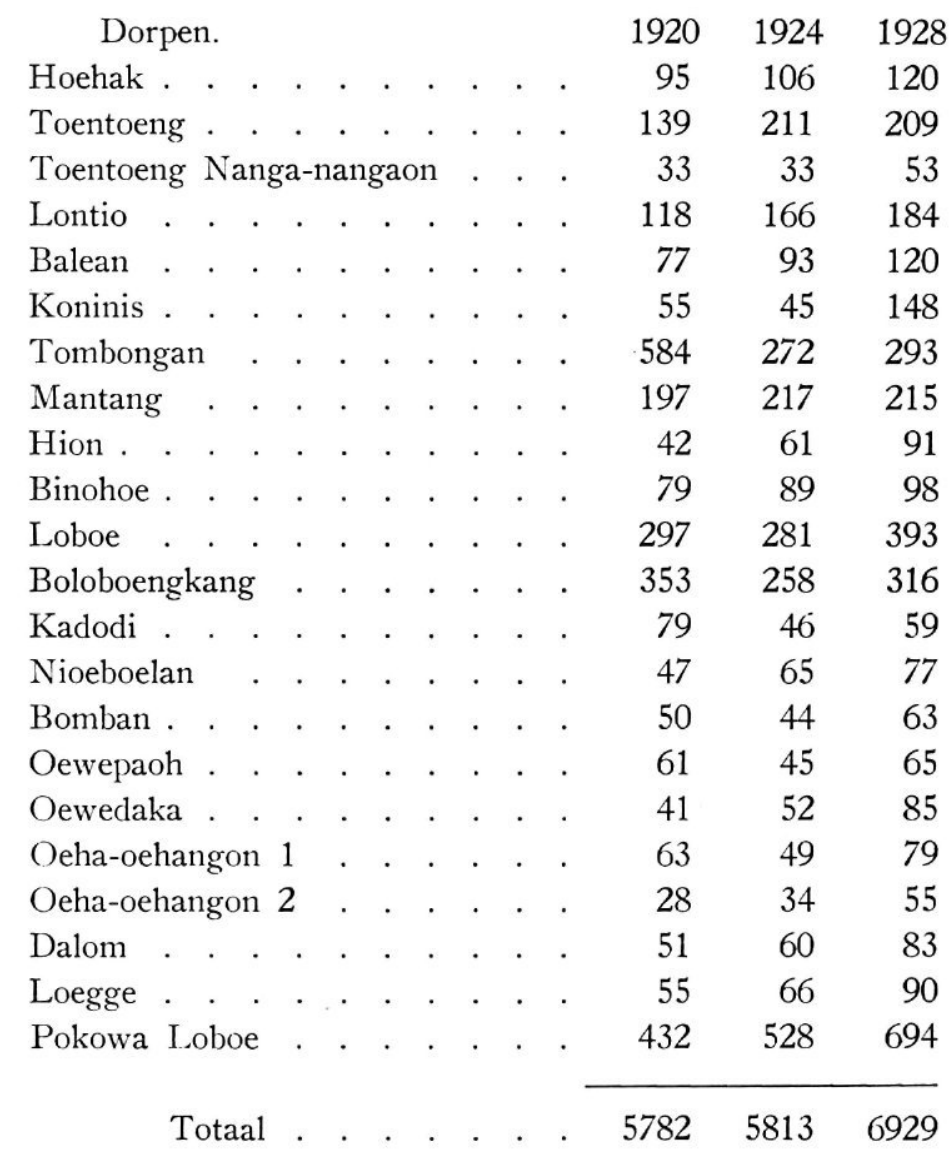




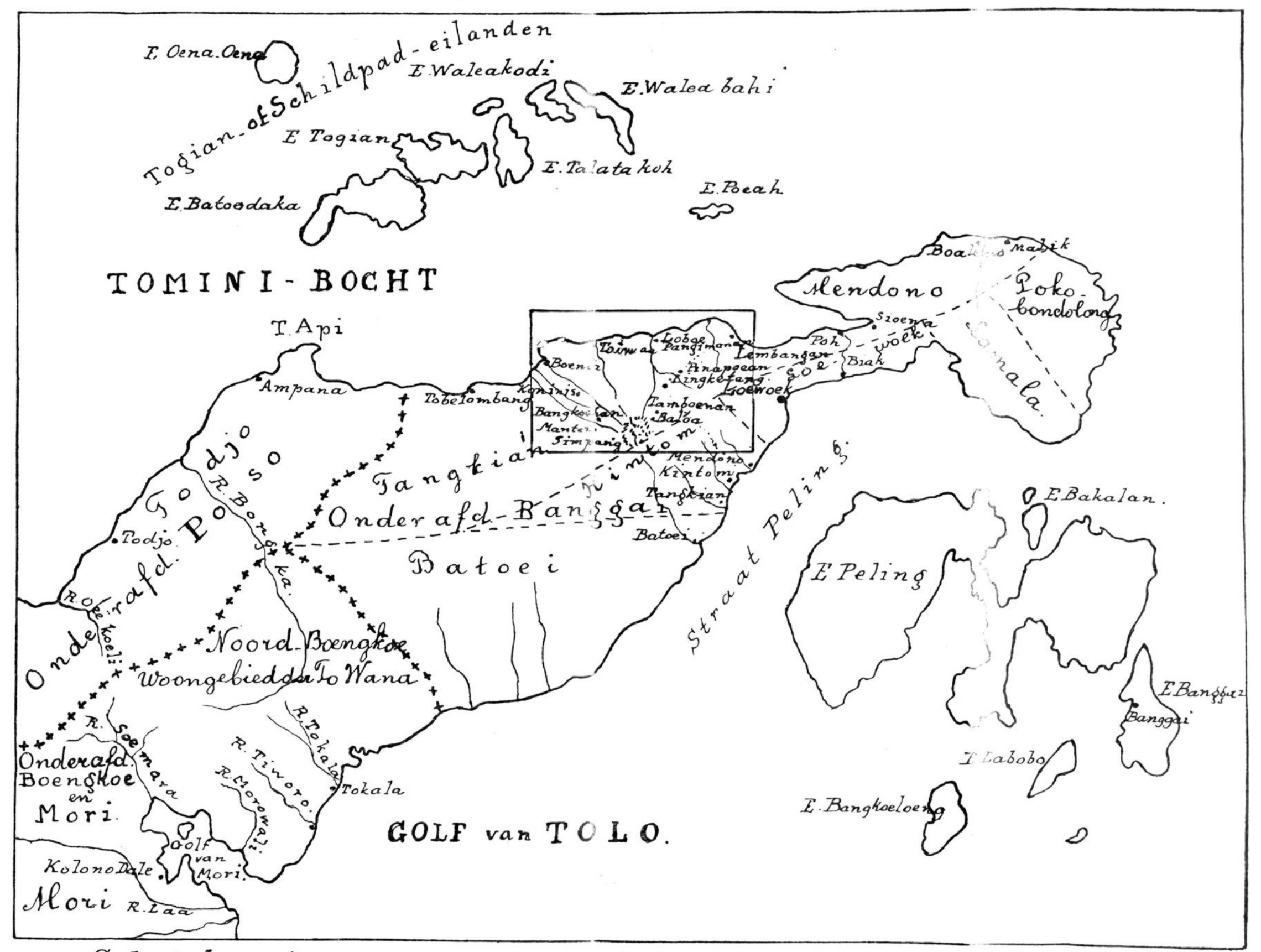

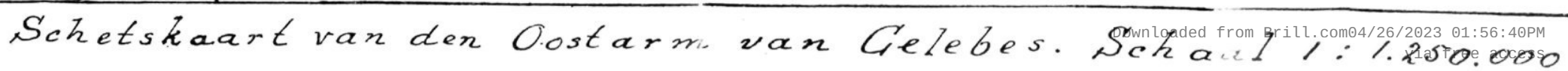


